FÁBIO GONZAGA DE CARVALHO - N. ․ USP 7019494.

\title{
A BOA-FÉ COMO CRITÉRIO DEFINIDOR DA EXTENSÃO DE DIREITOS TRABALHISTAS AOS EMPREGADOS PÚBLICOS NÃO SUBMETIDOS À PRÉVIA APROVAÇ̃̃̃ EM CONCURSO PÚBLICO E SUA DEMONSTRAÇẨO EM JUÍZO.
}

\begin{abstract}
Dissertação de Mestrado apresentada à Banca Examinadora da Faculdade de Direito da Universidade de São Paulo USP, como requisito parcial para a obtenção do Título de Mestre em Direito do Trabalho e Seguridade Social, desenvolvida sob a orientação do Prof. Homero Batista Mateus da Silva.
\end{abstract}

Universidade de São Paulo - USP

Faculdade de Direito - FADUSP.

São Paulo - Versão corrigida em 03.01.2014. A versão original, em formato eletrônico (PDF), encontra-se disponível na CPG da Unidade. 
FÁBIO GONZAGA DE CARVALHO - N. . USP 7019494.

\title{
A BOA-FÉ COMO CRITÉRIO DEFINIDOR DA EXTENSÃO DE DIREITOS TRABALHISTAS AOS EMPREGADOS PÚBLICOS NÃO SUBMETIDOS À PRÉVIA APROVAÇÃO EM CONCURSO PÚBLICO E SUA DEMONSTRAÇÃ̃O EM JUÍZO.
}

\begin{abstract}
Dissertação de Mestrado apresentada à Banca Examinadora da Faculdade de Direito da Universidade de São Paulo USP, como requisito parcial para a obtenção do Título de Mestre em Direito do Trabalho e Seguridade Social, desenvolvida sob a orientação do Prof. Homero Batista Mateus da Silva.
\end{abstract}

Data da banca:

Nome:

Título:

Instituição:

Nome:

Título:

Instituição:

Nome:

Título:

Instituição: 
Dedico a presente pesquisa à Aline Paula Bonna, Iracema Gonzaga Limas e Samar Elias Jeradi, mulheres que colaboraram e colaboram com minha caminhada. 
Agradeço a Deus pelos sonhos realizados, pelas lutas e pelo constante desejo de melhora. Agradeço ao Prof. Homero Batista Mateus da Silva pelos ensinamentos ministrados, pela oportunidade dada e, principalmente, por ser um exemplo de que a grandeza intelectual não representa arrefecimento da humildade. 


\section{RESUMO.}

O presente trabalho possui preponderantemente a natureza de pesquisa teórica, sem, contudo, olvidar-se aspectos empíricos, documentais e históricos. As múltiplas naturezas decorrem da relevância dos fundamentos teóricos e do caráter imprescindível dos documentos existentes e da história por de trás das normas pertinentes. O objetivo desta pesquisa foi a busca de um critério jurídico que sirva como alternativa à solução ofertada pelo Tribunal Superior do Trabalho - TST, por meio da Súmula n. 363 aos empregados que prestem trabalhos à Administração Pública à míngua de prévia aprovação em concurso público. Pretendeu-se demonstrar a necessidade de se diferenciarem os trabalhadores que ignoram a prestação de trabalho para a Administração Pública daqueles que têm conhecimento da natureza jurídica de seu empregador em um cenário em que o concurso público é pressuposto formal sem o qual o ato jurídico que vincula os sujeitos da relação de emprego é invalido. Como referências teóricas, foram utilizados o Direito Administrativo, nomeadamente a teoria dos atos administrativos, o Direito do Trabalho, em especial a teoria dos contratos de trabalho, a teoria geral dos atos jurídicos, nomeadamente as teorias da nulidade e da ineficácia, a ponderação de princípios, a harmonização de princípios, a boa-fé e, ainda, a teoria geral da prova em razão das repercussões processuais do estudo. Por fim, como resultado, demonstrou-se que a utilização da boa-fé como critério diferenciador da concessão de direitos aos empregados que trabalhem para a Administração Pública sem a prévia aprovação em concurso público proporciona harmonização entre o princípio do valor social do trabalho e os princípios regentes da Administração Pública.

\section{PALAVRAS-CHAVE.}

Contrato de trabalho, relação de emprego, pressupostos de validade, elementos de existência, concurso público, boa-fé, ônus da prova.

\section{ABSTRACT.}

This work has the primary nature of theoretical research, without neglecting its empirical, documentary and historical aspects. The multiple natures derive from the 
relevance of the theoretical and essential nature of existing documents and the story behind the relevant standards. The aim of this study was to search for a legal test that serves as an alternative to the solution presented by the Superior Labor Court via Precedent n. 363 to employees who serve the Public Administration without prior approval in a Public Contest. It was intended to demonstrate the need to differentiate the workers who are not aware of their relationship with the Public Administration from those aware of the legal nature of their employer in a scenario in which the Public Contest is a formal requirement without which the legal act that binds the subjects of the employment relationship is invalid. Used as theoretical references were the Administrative Law, namely the Theory of Public Acts, the general theory of labor law, especially of labor contracts, the general theory of legal acts, including the theories of invalidity and ineffectiveness, the weighting of principles, harmonization of principles, good faith and also the general theory of proof because of the procedural implications of the study. Finally, as a result, it was shown that the use of good faith as a differentiation criterion for granting rights to employees who work for the Public Administration without prior approval in a Public Contest offers harmonization between the principle of the social value of work and the governing principles of public administration.

\section{KEY WORDS.}

Employment contract, the employment relationship, the validity of assumptions, elements of existence, Public Contest, good faith, the burden of proof. 


\section{Sumário}

RESUMO.

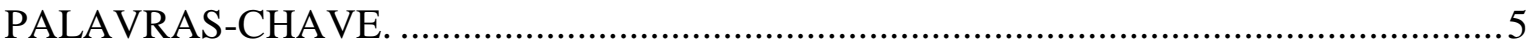

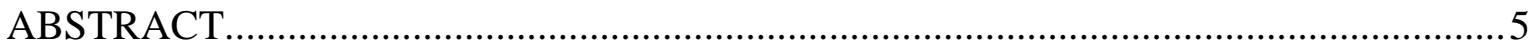

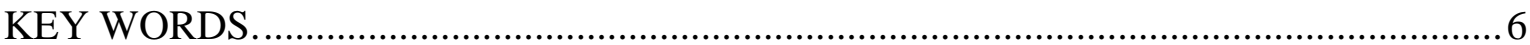

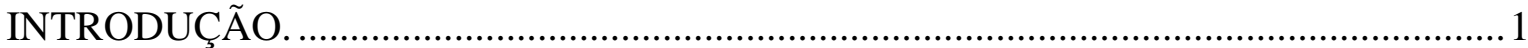

RELAÇÃO JURÍDICA DE EMPREGO.........................................................................

$O$ nascimento da relação de emprego. $O$ negócio jurídico como causa da relação de emprego com a Administração Pública. ...................................................................... 14

Contornos gerais de uma relação jurídica de emprego................................................19

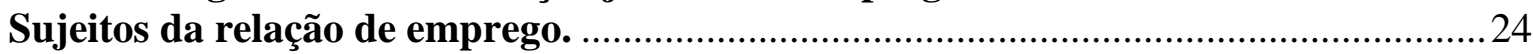

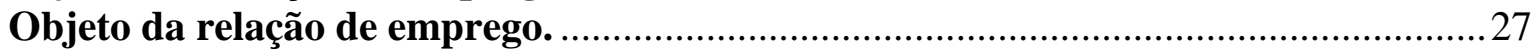

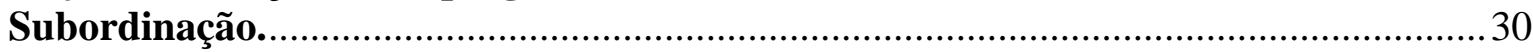

Posição no tempo, no espaço, causa e vontade. ............................................................... 32

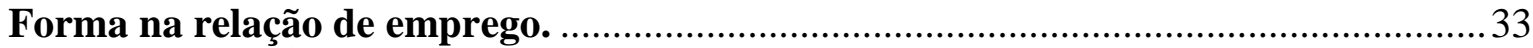

CONCURSO PÚBLICO: PRESSUPOSTO FORMAL DA RELAÇÃO DE EMPREGO COM A ADMINISTRAÇÃO PÚBLICA........................................................................

Concurso público no histórico constitucional brasileiro ...............................................5

Ausência de concurso público. Posição do TST e seus fundamentos. ..............................67

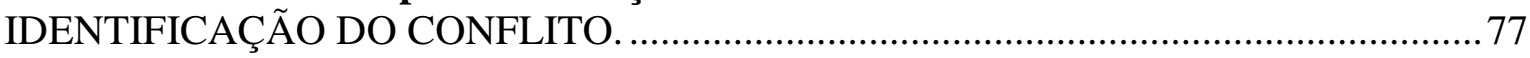

Nulo e anulável nos Direitos Civil, Trabalhista e Administrativo.....................................78

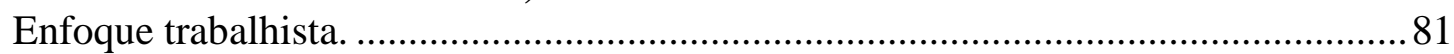

Enfoque administrativista. Invalidação ou anulação. Convalidação. Teoria do fato

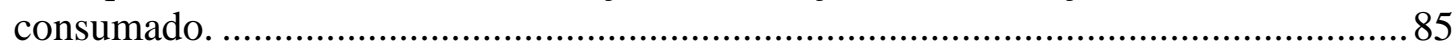

Pontos de aproximação entre os enfoques trabalhista e administrativista....................91

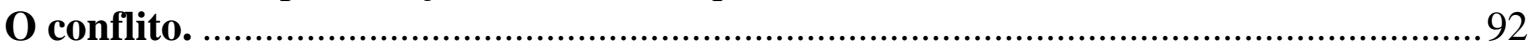

Possíveis soluções. Meios de aplicação das normas jurídicas. .......................................93

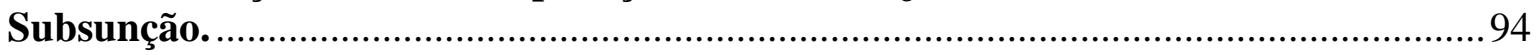

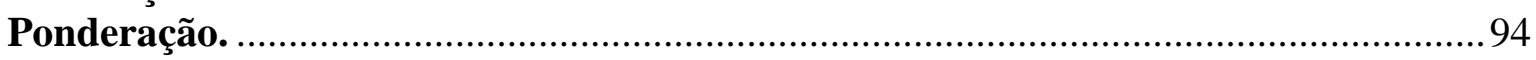

Harmonização de princípios. Extensão de efeitos.........................................................96

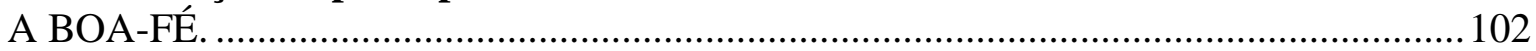

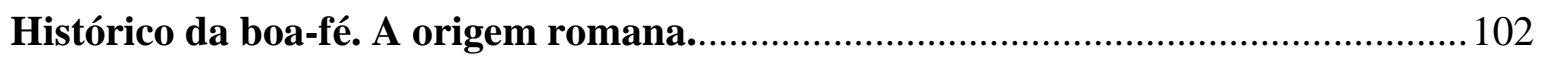

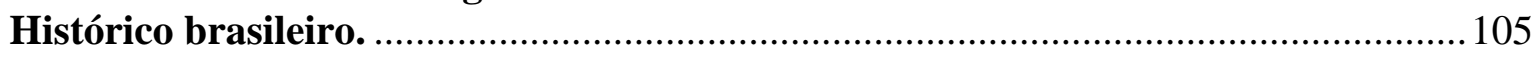

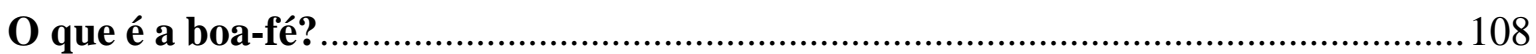

Boa-fé como fato e como princípio. .................................................................... 110

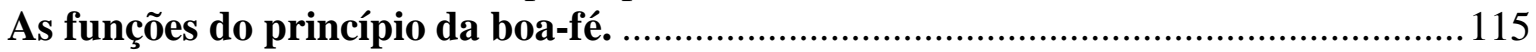

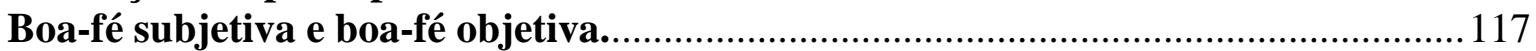

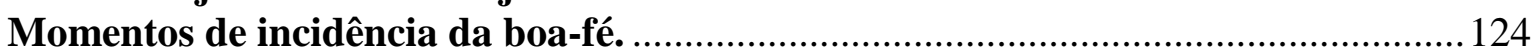

Aplicação da boa-fé à Administração Pública. …………………………………....... 126

Violação da boa-fé objetiva pela Administração Pública...…………………………....132

O desconhecimento do trabalhador - boa-fé subjetiva. ……………………………....134

Ação de improbidade administrativa: o caminho moralizante. ...................................137

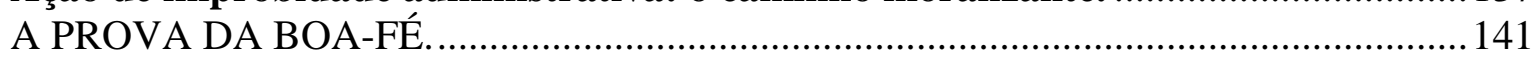

A relevância da prova da boa-fée........................................................................... 141

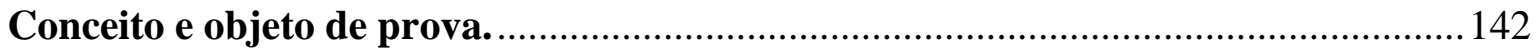

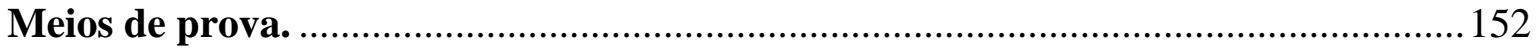





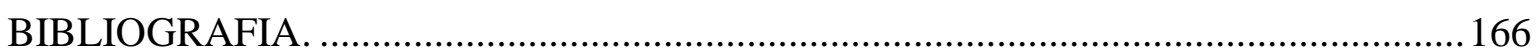




\section{INTRODUÇÃO.}

O interesse no presente estudo nasce de sugestão feita por Homero Batista Mateus da Silva que se questiona, ao tratar da exigência de concurso público para acesso aos postos de trabalho na Administração Pública e sobre os entendimentos do TST e do Supremo Tribunal Federal - STF, a esse respeito, se “... a omissão do concurso público é realmente imputável ao trabalhador?"1 . Em busca de resposta satisfatória a essa indagação, propusemo-nos ao estudo da boa-fé como critério definidor da extensão de direitos trabalhistas aos empregados públicos não submetidos à prévia aprovação em concurso público, porquanto se cuida de instituto com múltiplas funções no Direito, inclusive com a possibilidade de produção de efeitos em atos jurídicos nulos.

A boa-fé ocupa a mente dos estudiosos do Direito, ao menos, desde o Direito romano. Todavia, não é muito remota, tampouco significativa, a produção intelectual a respeito da boa-fé no Direito do Trabalho. É certo que Américo Plá Rodriguez², ao sistematizar os princípios do Direito do Trabalho, fez menção à boa-fé e nisso foi seguido pela maioria dos doutrinadores que o sucederam. Mas, essa alusão, em que pese prodigiosa, não se direcionou a resolver problemas como o da concessão de direitos em relações de emprego nulas, nomeadamente por ausência de concurso público, forma indispensável à validade de relações de emprego com a Administração Pública, muito em razão de os estudos do professor uruguaio não terem se direcionado ao Direito brasileiro e suas especificidades e, ainda, em razão de o concurso público ter se tornado exigência de acesso à quase universalidade de cargos e empregos públicos somente com a Constituição de 1988. Por oposição, não podemos afirmar a omissão cabal de estudos, visto que encontramos escritos específicos sobre o assunto, como o artigo científico da lavra de Gustavo Alexandre Magalhães e Jorge Luiz Souto Maior ${ }^{3}$, que afirmam categoricamente que a boa-fé deve ser utilizada na solução de conflitos que digam respeito a trabalhadores que ocupam, sem a prévia aprovação em concurso público, postos na estrutura estatal.

\footnotetext{
${ }^{1}$ SILVA, Homero Batista Mateus da. Curso de direito do trabalho aplicado, vol. 6: contrato de trabalho. Rio de Janeiro: Elsevier, 2009, p. 24.

${ }^{2}$ RODRIGUEZ, Américo Plá. Princípios de direito do trabalho: tradução de Wagner D. Giglio. São Paulo: Ltr. Ed. Da Universidade de São Paulo, 1978. p. 16.

${ }^{3}$ MAGALHÃES, Gustavo Alexandre; MAIOR, Jorge Luiz Souto. Efeitos da nulidade na contratação de servidores públicos. in O Servidor público e a Justiça do Trabalho: homenagem ao Ministro Ronaldo José Lopes Leal. José Ronald Cavalcante Soares, coordenador. São Paulo: LTr, 2005, p. 125.
} 
Logo, a escassez de estudos sobre o tema torna necessária a elaboração de pesquisas a seu respeito.

Em complemento, a relevância do tema "a boa-fé como critério definidor da extensão de direitos trabalhistas aos empregados públicos não submetidos à prévia aprovação em concurso público e sua demonstração em juízo" insere-se também na utilidade de se apresentarem soluções diversas da adotada pelo TST por meio de sua Súmula de n. ${ }^{\circ} 363$, que restringe os direitos dos trabalhadores em um contrato nulo à concessão de salários pelas horas trabalhadas e aos depósitos de Fundo de Garantia de Tempo de Serviço - FGTS. Utilidade, esclareça-se, pois a solução do TST é severa quanto a esses trabalhadores e não pondera em suas conclusões o fato de o sujeito da relação de emprego estar, ou não, de boa-fé, o que sugere a prevalência de preceitos administrativistas sobre os trabalhistas, visto que o apego à nulidade da relação de emprego acaba por mitigar os direitos do trabalhador, o que não nos parece a melhor solução.

Nessa linha, o problema que se nos apresenta é o da identificação da boa-fé como critério definidor da extensão de direitos e a necessidade de fundamentação jurídica de sua escolha. $\mathrm{O}$ atendimento desse mister passa pela identificação dos elementos e pressupostos da relação de emprego, pelo enfrentamento da teoria das nulidades em searas distintas do Direito, pela determinação da zona de tensão entre princípios administrativistas e trabalhistas, por meio da identificação de possíveis soluções, com o destaque da posição ocupada pela boa-fé e no enfretamento das dificuldades processuais de sua demonstração em juízo.

Concluindo, é imperioso delimitar alguns contornos da pesquisa, como território, tempo e sujeitos. As respostas procuradas voltam-se a problemas ocorridos no Brasil, de maneira que são invocadas normas jurídicas do Direito brasileiro, mas sem que isso implique ojeriza ou ignorância sobre o Direito estrangeiro, quando relevante. $\mathrm{O}$ corte histórico possui como ponto central a Constituição da República de 1988 - CR, momento a partir do qual, como dito, ampliou-se a exigência de concurso público. Em seguida, os sujeitos que nos restringimos a pesquisar são aqueles introduzidos em uma relação jurídica negocial com entes da Administração Pública Indireta que têm personalidade jurídica de Direito Privado, vale dizer, os empregados e as empresas estatais como empregadoras. 


\section{RELAÇÃO JURÍDICA DE EMPREGO.}

A prestação de trabalho no seio de uma relação de emprego faz surgir diversos direitos e, para os ocupantes de polo oposto da vinculação, múltiplos deveres ou sujeições. Têm especiais revelo o pagamento de salário pelo empregador em contraprestação ao trabalho prestado pelo empregado em um determinado período e a própria colocação da mão de obra à disposição daquele que assume os riscos do empreendimento. Para além desses direitos e deveres básicos, podemos fazer menção ao direito à observância da limitação da jornada diária e semanal, ao repouso semanal remunerado e ao trabalho em ambiente salubre e não perigoso. Veja-se que esses direitos decorrem de um vínculo entre dois sujeitos, ao menos, acerca de um objeto específico, o trabalho subordinado. Essa vinculação é abordada pelo art. 442 da Consolidação das Leis do Trabalho - CLT, na literalidade:

\footnotetext{
"Art. 442 - Contrato individual de trabalho é o acordo tácito ou expresso, correspondente à relação de emprego".
}

O exame das poucas palavras que inauguram o Título IV, intitulado "Do contrato individual de trabalho", revela uma série de dificuldades, por exemplo, a distinção entre trabalho e emprego e, também, a diferença entre relação de emprego e contrato de emprego.

A primeira tensão apresentada, distinção ente trabalho e emprego, é resolvida com o estabelecimento do trabalho como gênero do qual o emprego é apenas uma das espécies. Portanto, os termos não se confundem, sendo possível se identificarem outras atividades como trabalho, e não emprego, tais como as figuras do trabalho voluntário, o parceiro, o meeiro e o servidor estatutário ${ }^{4}$. Em outros termos, a expressão relação de

\footnotetext{
${ }^{4}$ Homero Batista Mateus da Silva relata que “... a primeira tensão escondida no art. 442 da Consolidação das Leis do Trabalho se refere ao conceito de trabalho em contraposição ao sentido de emprego. Com base no uso indiscriminado das palavras pelo legislador, inclusive pela Constituição Federal de 1988, é possível sustentar que as expressões sejam sinônimas na maioria das acepções. Assim, diz-se indistintamente "arranjei um trabalho" ou "encontrei um emprego", da mesma forma que "ofereço trabalho para vigilantes" ou "vagas para emprego de garçom". No entanto, é consensual nos estudos jurídicos que a expressão trabalho corresponde a um conjunto maior, dentro do qual palavra emprego é apenas uma das possibilidades. Há incontáveis outras formas de trabalho que não se revestem das características de emprego. Trabalho abrange o voluntariado, por exemplo, mas paras ser empregado pe indispensável a existência de alguma forma de remuneração, donde o requisito da onerosidade e da alteridade. Estudar é também trabalhar, a bem da verdade. Os servidores públicos estatutários trabalham para a administração pública, conquanto não sejam considerados seus empregados por delineamentos próprios do legislador. Os representantes comerciais
} 
trabalho possui caráter genérico, referindo-se a todas as relações marcadas pela peculiaridade de possuírem, como sua prestação essencial, uma obrigação de fazer consubstanciada no trabalho de um ser humano. Por sua vez, a expressão relação de emprego é apenas uma das modalidades específicas da relação de trabalho, correspondente a um tipo legal e específico, que não deve ser confundido com as demais modalidades existentes ${ }^{5}$.

Outro embate que também se depreende do art. 442 da CLT é a tensão existente entre relação e contrato de emprego ${ }^{6}$. A utilização indistinta dos termos não pode ser tida como correta, quanto mais diante de argumentos históricos e doutrinários que subsidiam o trato diferenciado, o que indica a ausência de modernidade em seus estudos e explicações. Adicionalmente, a questão envolve ou envolveu a própria independência do Direito do Trabalho em relação ao Direito Civil. Desse modo, é de extremo valor a exposição dos argumentos que subsidiaram a distinção entre relação e contrato de emprego e, também, os porquês da afirmação da autonomia do contrato de trabalho e do Direito do Trabalho em relação ao Direito Civil.

No decorrer da história da humanidade, foram elaborados diversos textos legais que se ocuparam do trabalho humano, como, a partir do século XIX, a lei espanhola de 1900 que proibiu o trabalho de menores de dez anos, a lei americana de 1901 sobre condições de trabalho, a lei italiana de 1908 sobre trabalho noturno na indústria panificadora, a lei portuguesa de 1911 que instituiu descanso aos domingos e a lei inglesa que regulou a atividade de sindicatos ${ }^{7}$. Como é comezinha na ciência jurídica, a singela existência de uma lei ou de uma pluralidade assistemática de leis é insuficiente à afirmação

autônomos e os sócios quotistas das empresas laboram tanto quanto os empregados, mas não seguem o mesmo regime jurídico. Parceiros e meeiros trabalham, ainda que não na forma de emprego. Uma das atividades de trabalho mais cansativas e repetitivas que existe passa muito longe do conceito de emprego - as lides domésticas da dona de casa. E assim sucessivamente. Daí ser possível dizer que, onde houver emprenho de energia humana, ali haverá trabalho, sob qualquer condição, a título gratuito ou oneroso, com ou sem subordinação às ordens alheias, de forma repetitiva ou ocasional. Todavia, para que o trabalho atinja o patamar de emprego, faz-se necessário que a atividade seja revestida das exigências legais em torna da subordinação, onerosidade, pessoalidade e habitualidade, conforme exaustivamente explanado no início desta coleção". In: SILVA, Homero Batista Mateus da. Curso de direito do trabalho aplicado, vol. 6: contrato de trabalho. Rio de Janeiro: Elsevier, 2009, pp. 5-6.

${ }^{5}$ DELGADO, Mauricio Godinho. Curso de direito do trabalho. 10. ed. São Paulo: LTr, 2011, pp. 275-276.

6 "A Comissão Elaboradora da CLT era composta por cinco membros: os Procuradores da Justiça do Trabalho Luiz Augusto Rego Monteiro (institucionalista); Arnaldo Sussekind (contratualista), Dorval Lacerda (institucionalista) e Segadas Vianna (contratualista) e o Consultor Jurídico do Ministério do Trabalho, Oscar Saraiva (contratualista). Na época, Arnaldo Sussekind contava com apenas 24 anos de idade". In: CASSAR, Vólia Bomfim. Direito do trabalho. 4. ed. Niterói: Impetus, 2010, p. 241.

${ }^{7}$ SOUTO MAIOR, Jorge Luiz. Curso de direito do trabalho: teoria geral do direito do trabalho. vol I. Parte I. São Paulo: LTr, 2011, pp. 236-242. 
da existência de uma especialidade do Direito, o que depende, além da legislação específica, da existência de princípios próprios, razoável número de estudos doutrinários a respeito e um objeto de estudo próprio ${ }^{8}$.

Interessa notar que somente após a I Guerra Mundial tem início perene e sistemática produção legislativa acerca de proteção ao trabalho, como as leis alemãs sobre higiene, segurança e seguros sociais; muito embora a Constituição Mexicana de 1917, mesmo antes do findar do conflito global, já houvesse estabelecido direitos aos trabalhadores que se lhes aplicavam pela existência de singelo vínculo com remuneração. Além do objeto, as legislações alemã e mexicana comungaram da mesma exigência necessária à aplicação dos direitos conquistados ou concedidos, qual seja, o fato de o pessoal estar vinculado ao empreendimento com o recebimento de remuneração ${ }^{9}$. Essa nova diretriz, ao impor direitos de observância obrigatória na relação entre particulares, contrariou em parte o Direito até então conhecido - o Direito Civil, que possuía à época a autonomia da vontade como pedra de toque, isto é, a ampla possibilidade de os particulares resolverem seus conflitos de interesse, criarem associações, efetuarem o escambo dos bens e dinamizarem a vida em sociedade ${ }^{10}$, inclusive, por meio da estipulação dos direitos e deveres incidentes nos contratos.

Transparece que o trabalho subordinado, que até então era identificado como empreitada ou prestação de serviços pelo Direito Comum, tornou-se destinatário de legislação específica, o que gerou nos estudiosos do novo o intento, se não, a necessidade de apresentarem novos fundamentos, princípios e meios de aplicação que, em grande parte, afastassem a lógica do Direito Civil.

Não se pode perder de vista que as normas jurídicas até então vigentes no século XX amparavam-se em uma ideologia liberal, fruto das revoluções americana ${ }^{11}$ e francesa

\footnotetext{
${ }^{8}$ Embora não seja sua a compreensão, encontramos em Mauro Schiavi a menção aos requisitos necessários à afirmação da autonomia científica de determinada especialidade. In: SCHIAVI, Mauro. Manual de Direito Processual do Trabalho. 2. ed. São Paulo: LTr, 2009, p. 85.

${ }^{9}$ GOMES, Orlando. GOTTSCHALK, Élson. Curso de direito do trabalho. Rio de Janeiro: Forense, $2006, \mathrm{p}$. 142.

${ }^{10}$ SILVA, Clóvis V. do Couto e. A obrigação como processo. Rio de Janeiro: Editora FGV, 2007, p. 24.

11 “...a Nova Inglaterra - constitui-se como sociedade tipicamente burguesa, isto é, como um grupo organizado de cidadãos livres, iguais perante a lei, e cuja diferenciação interna só podia existir em função da riqueza material. É verdade, porém, que nas colônias do sul, em lugar da divisão estamental introduziu-se a escravidão negra, em flagrante violação ao princípio da igualdade fundamental do ser humano " ainda "É claro que a igualdade de condição jurídica não significou, de modo algum, o nivelamento sociedanômico da sociedade americana". In: COMPARATO, Fábio Konder. A afirmação histórica dos direitos humanos. 6.ed. ver. e atual. São Paulo: Saraiva, 2008, pp. 100-101.
} 
ocorridas no século XVIII, que pregavam o afastamento do Estado das relações sociais, notadamente das relações entre particulares ${ }^{12}{ }^{13}$. Mencionado afastamento, reconhecido e protegido pela ordem jurídica ${ }^{14}$, acabou por gerar zonas de incompetência do Estado, searas em que apenas a vontade dos sujeitos importava, vale dizer, a autonomia da vontade determinava os rumos das relações sociais, o que não tardou em gerar distorções e abusos. Mas não coube apenas à ausência do Estado o surgimento do Direito do Trabalho, ela está atrelada, também ou somente, ao menos segundo Jorge Luiz Souto Maior, a leis de incentivo ao trabalho, leis de liberação da compra e venda da força de trabalho, como o Código de Napoleão de 1804, e leis de repressão como a Lei Le Chapelier, isso para que se estabelecesse uma abundância de mão de obra, necessária à maximização de ganhos em prejuízo aos salários, algo importante ao sistema burguês desde então regente e determinante das relações sociais ${ }^{15}$.

Como dito, a prevalência do liberalismo nas relações sociais representou o reconhecimento pelo Estado de poderes aos indivíduos, as chamadas liberdades, que consagravam o direito de agir ou não agir segundo os próprios interesses ${ }^{16}$, repousando na vontade dos sujeitos os limites ao conteúdo dos negócios jurídicos celebrados.

Veja-se que um novo direito que pretendesse equilibrar as relações de trabalho subordinado deveria romper com a sujeição sem limites do conteúdo do contrato à autonomia da vontade das partes. Esse mister dependia da formulação de um novo Direito, amparado em fundamentos, princípios e regras jurídicas diversos, em seu conjunto, dos utilizados pelo Direito Comum. Como é sabido, o desafio foi enfrentado pelo Direito do Trabalho que pretende a manutenção do equilíbrio da relação de emprego, se vale de princípios próprios, como o da proteção e possui vasta legislação.

Contudo, para que os princípios e as regras do Direito do Trabalho tivessem aplicação era necessário que não pudessem ser excluídos por seus sujeitos, de maneira que eram compreendidos como direitos mínimos de observância inafastável, o que gerou

\footnotetext{
${ }^{12}$ RIVERO, Jean. HUGUES, Moutouh. Liberdades públicas. Tradução Maria Ermantina de Almeida Prado Galvão. São Paulo: Martins Fontes, 2006, pp. 33, 59-60.

${ }^{13}$ SOUTO MAIOR, Jorge Luiz. Curso de direito do trabalho: teoria geral do direito do trabalho. vol I. Parte I. São Paulo: LTr, 2011, p. 98, 114.

${ }^{14}$ FERREIRA FILHO, Manoel Gonçalves. Direitos humanos fundamentais. 9. ed. rev. São Paulo: Saraiva, 2007 , p. 28.

${ }^{15}$ SOUTO MAIOR, op. cit., p. 151.

${ }^{16}$ ALEXY, Robert. Teoria dos Direitos Fundamentais. Tradução de Virgílio Afonso da Silva da $5^{\mathrm{a}}$ edição alemã. Malheiros, 2008, p.222.
} 
conflitos com a autonomia da vontade que se instrumentalizava na livre estipulação do teor dos contratos. A imposição de conteúdo às relações de trabalho subordinado, independentemente da vontade das partes, sugere, como destacado por Délio Maranhão, que contrato de trabalho é um contrato regulamentado ${ }^{17}$, isto é, com conteúdo mínimo estabelecido por um terceiro.

Foi justamente a forte identificação do contrato como instrumento da autonomia da vontade que ocasionou uma inicial recusa de sua utilização nas relações de trabalho. Convém destacar que as relações entre particulares, quando imperante apenas o Direito Civil, eram um campo hostil à presença do Estado, tendo em vista que a liberdade era compreendida como poder de autodeterminação em virtude do qual o próprio homem escolhe seus comportamentos pessoais ${ }^{18}$. Entretanto, seu uso desmoderado provou o agravamento da situação de muitos trabalhadores e, em certa medida, corroborou com o surgimento de novos direitos ${ }^{19}$.

A respeito da negação da natureza contratual da relação de emprego, impõe-se a identificação das concepções anticontratualistas, quais sejam, a teoria da relação de emprego, fortemente desenvolvida no México e na Alemanha, e a teoria institucionalista, de origem francesa. Há como elemento comum às diversas compreensões, a busca da autonomia do Direito do Trabalho em relação ao Direito Civil, peculiaridade que restará mais evidente nos parágrafos seguintes.

Foi justamente o afastamento da supremacia da autonomia privada das relações de trabalho subordinado que fez com que legislação e doutrina negassem a aplicação do Direito Civil. Isso corrobora na explicação da ojeriza dos estudiosos do Direito do Trabalho dos primeiros tempos à figura do contrato, que servia como instrumento da vontade das partes, o que era incompatível, ao menos em parte, com as inovações legislativas.

Os conflitos decorreram, em grande parte, da tendência de se interpretarem e de se aplicarem os novos direitos à luz dos preceitos aplicados ao Direito Civil, já existente e consolidado pela experiência social. Com isso, a negação da natureza contratual ou de sua

\footnotetext{
17 SÜSSEKIND, Arnaldo. Institutições de direito do trabalho. Volume I. 22. ed. atual. Por Arnaldo Süssekind e João de Lima Teixeira Filho. São Paulo: LTr, 2005, p. 251.

${ }^{18}$ RIVERO, Jean. HUGUES, Moutouh. Liberdades públicas. Tradução Maria Ermantina de Almeida Prado Galvão. São Paulo: Martins Fontes, 2006, p. 8.

${ }^{19}$ Ibidem, pp. 26, 69, 74, 80-81.
} 
influência na relação de trabalho foi afirmada na Alemanha por doutrinadores como Menger, Gierke e Potthof e, no México, por Mario De La Cueva ${ }^{20}$, na tentativa de se afastar a incidência de preceitos civilistas ao Direito que nascia, em particular, por serem, segundo eles, estranhas ao vínculo de emprego as relações de troca próprias do Direito Comum, pois o trabalhador não promete uma prestação material, mas obriga a si próprio, vinculando-se ao empregador como a uma associação ou família, vale dizer, a empresa era a célula primária da vida econômica, possuindo nítidas feições de comunidade ${ }^{21}$.

Para as teorias em relevo, igualmente, a distinção entre a relação de trabalho e as relações do Direito Civil residiria na característica de a generalidade das vinculações humanas estarem amparadas na autonomia da vontade, que acabaria por ser a fonte

20 O professor mexicano destaca as dificuldades iniciais de separação do Direito do Trabalho do Direito Civil com os seguintes dizeres: “...los maestros de derecho civil sintieron el peso de la norma de los códigos que establecía y aun consigna, que solo las cosas que están em el comercio pueden ser objeto de contratación. Quienes siguieron al Código civil de Francia vivian em la cárcel del contratato de arrendamento de servicios, pero fueron vários los escritores a los que repugnó la Idea de que ele hombre y las bestias de carga y de tiro estuvieran regidos por las mismas disposiciones: en un ensayo que posteriormente rectificó, Francesco Carnelutti lanzó la Idea de que la relacíon de trabajo era un contrato de compra-venda, semejante al contrato para el suministro de energía elétrica, pues em virtud de él, los trabajadores vendían su energia de trabajo al empresário, quien podía utilizarla em la forma que estimara conveniente; Chatelain y Valverde sostuvieron que debería considerarse a la relación como un contrato de sociedad, lo que tendría la ventaja de salvar la dignidad humana, pues em él, los trabajadores aportaban su energía de trabajo y el empresário el capital, a fin de compartir las utilidades, de donde resultaba que el salario era la particiátión que correpondía al trabajo; y no falto quien dijera que era una espécie de mandato que el patrono otorgaa al trabajador para la ejecución de ciertas actividades. Los autores de nuestro Código civil de 1870, segun apuntamos em um capítulo anterior (La creación del derecho mexicano del trabajo) afirmaron em la Exposición de motivos sea cual fuere la esfera social em que el hombre se halle colocado, no puede ser comparado con los seres irracionales y menos aún con las cosas inanimadas, pues parece um atentado contra la dignidad humana ilamar alquiler a la prestación de servicios personales. Más semejanza tiene con el mandato, porque em ambos contratos, el mandante encarga a outro la ejecución de ciertos actos... La aptitud será más intelectual em uno y más material em outro, pero em ambos supone uma cuaidad moral; porque nadie puede prestar um servicio, se el que fuere, sin emplear su libre voluntad y poner em ejercicio alguna de las facultades peculiares del hombre". In: El nuevo derecho mexicano del trabajo: historia, princípios fundamentales, derecho individual y trabajos especiales. Mexico: Editorial Porrua, 1977, p. 181.

${ }^{21}$ Professam Orlando Gomes e Élson Gottschalk que "entre os anos de 1922 e 1933, essas idéias de Potthof influenciaram grandemente outros juristas alemães e os trabalhos de Sinzheimer, de Molitor, de Nikisch aproximaram-se muito delas, pelas suas conclusões. A reação contra a predominância exclusiva do contrato era evidente. Parecia, então, que o pensamento prevalente conduzisse à concepção dualista das relações de trabalho: em parte ligadas ao contrato, em parte à incorporação do trabalhador ao estabelecimento. Após a lei de 1934, que organizou a Frente do Trabalho nazista, este dualismo mais se acentuou, destacando com mais vigor a relação de trabalho como uma derivação da incorporação na empresa. Como se sabe, o regime nacional-socialista estruturou a sua frente de trabalho à base da lei orgânica intitulada "Gesezt zur Ordnung der Nazionalen Arbeit". Com ela pretendeu-se eliminar a luta a luta de classes. Foram eliminados todos os meios que podiam servir de instrumento a essa luta e manter vivo o conflito entre o capital e o trabalho. Dessarte, aboliram-se as coalizões operárias (Koalitionem), as associações profissionais (berufsvereine), os sindicatos (Gewerkschaften) e as associações patronais (Arbeitsgeberverbande). Com a supressão de organizações de luta, desapareceu o Direito Coletivo do Trabalho”. In: GOMES, Orlando. GOTTSCHALK, Élson. Curso de direito do trabalho. Rio de Janeiro: Forense, 2006, pp. 142-143. 
criadora de direitos, ao passo que, na relação de emprego, a prestação do trabalho, por si só, já teria a aptidão de criar direitos e obrigações ${ }^{22}$.

Nessa linha, o Direito do Trabalho pretendeu romper com os vínculos existentes com o Direito Civil. Essa desvinculação fez-se necessária em razão do novo objetivo de que se ocupava aquele ramo jurídico, qual seja, proteger o trabalho, e não um simples acordo de vontades. Mas não é só, a ideia da separação da relação de trabalho das concepções civilistas repousa em fundamentos como dignidade do trabalho humano, que implica a impossibilidade de sua identificação com mercadorias ${ }^{23}$.

Desde 1948, a Organização Internacional do Trabalho faz expressa alusão à não mercantilização do trabalho humano ${ }^{24}$, o que afirma, simultaneamente, a dignidade que o trabalho deve proporcionar e a dignidade que repousa no próprio trabalho. Efetivamente, o trabalho não pode ser comparado ou receber o mesmo tratamento jurídico ofertado às mercadorias ou bens jurídicos em geral, o que é mais um indicativo de que o Direito do Trabalho não deve ser lido, interpretado e aplicado à luz dos preceitos do Direito Civil, muito embora o Direito Comum também verse sobre relações eminentemente humanas, como suas disposições sobre personalidade e família.

Mario de La Cueva chega a afirmar que a liberdade do trabalhador não repousa em um contrato, mas sim em um ato-condição, já que o simples fato de trabalhar, como dito, já enseja a aplicação dos direitos próprios da relação de emprego ${ }^{25}$. Veja-se que a teoria da relação de emprego não afasta a existência de atos de vontade, aliás, é indispensável ato de vontade do trabalhador para que tenha início a relação de emprego ${ }^{26}$. O mencionado autor mexicano destaca, também, que os defensores da teoria da relação de emprego nunca afirmaram que não pudesse existir ou que nunca existisse um acordo

${ }^{22}$ CUEVA, Mario De La. El nuevo derecho mexicano del trabajo: historia, princípios fundamentales, derecho individual y trabajos especiales. Mexico: Editorial Porrua, 1977, p. 182.

${ }^{23}$ Mario De La Cueva registra que a não aplicação dos preceitos civilistas constitui avanço ao asseverar que “...la Ley nueva resolvió la disputa em su art. tercero y em el precepto que exlcuyó al derecho común de las fuentes supletorias del derecho del trabajo. Delante de esta última soución, habría sido una aberración aceptar la Idea de la relaciónde trabajo com un contrato sujeto a las normas del derecho privado, Alguna vez nos perguntamos si seria aceptable la idea de un contrato regido por normas que no guardaran relación alguna con el derecho cicil y mercantil, pero nos convencimos de que era um impossible, porque estaria em uma contradicción insalvable con la idea del derecho del trabajo, que no protege lis acuerdos de voluntades sino el trabajo mismo...”. Ibidem, p. 187.

${ }^{24}$ Constituição da OIT. DECLARAÇÃO REFERENTE AOS FINS E OBJETIVOS DA ORGANIZAÇÃO INTERNACIONAL DO TRABALHO. I A Conferência reafirma os princípios fundamentais sobre os quais repousa a Organização, principalmente os seguintes: a) o trabalho humano não é uma mercadoria...

${ }^{25}$ Ibidem, p. 183.

${ }^{26}$ Ibidem, p. 188. 
prévio de vontades para formação da relação ${ }^{27}$. Com efeito, o acordo prévio de vontades também poderia representar a causa da relação de emprego, muito embora não fosse a única, mesmo porque, uma vez iniciada a prestação do trabalho, ela se desvincularia do ato que lhe deu origem e adquiria vida independente.

Por conseguinte, a teoria da relação de emprego admitia um acordo de vontades precedente à própria relação, hábil, por exemplo, a fixar a data de início dos trabalhos. Entretanto, não seria o acordo que daria início à relação de emprego, que se formaria no momento em que o trabalhador se incorporasse ao estabelecimento, ou melhor, com o exórdio dos trabalhos. Consequentemente, pela teoria da relação de emprego, empregados e empregadores poderiam firmar convenções particulares, criando obrigações além das estabelecidas pelo legislador. Assim, apesar de tratar de uma relação regida quase em sua integralidade por normas estatais, a teoria em exame admitia a figura do contrato ou do ato de vontade em relação a questões preliminares e à criação de normas complementares ${ }^{28}$. Aliás, contemporaneamente, no ordenamento jurídico brasileiro, a ideia de que os direitos previstos nas fontes heterônomas constituem, tão somente, um patamar mínimo é facilmente identificada no art. $7^{\circ}$, $c a p u t^{29}$ e inciso $\mathrm{XXVI}^{30}$, da CR.

Todavia, seguindo os ensinamentos de Orlando Gomes e Élson Gottschalk, podemos dizer que uma das fragilidades da teoria da relação de emprego é a afirmação de que as normas estatais que a regem se aplicam unicamente em seu curso, constatando os referidos autores que há também normas incidentes antes e depois da existência da relação. Prosseguem, realçando que a distinção entre relação e contrato não é substancial, pois significa, em verdade, uma exageração da diferença entre aspectos de uma mesma realidade. Com efeito, o contrato é o aspecto subjetivo de um fato que se objetiva na relação, mas que não é indispensável, porquanto diversos efeitos jurídicos nascem do singelo acordo de vontades. Desse modo, não se pode questionar que a produção de efeitos

\footnotetext{
${ }^{27}$ Vejamos a literalidade dos dizeres: "el matiz segundo apunta a la necesidad o la posibilidad, por lo menos, de um acuerdo de voluntades previo a la iniciación de la prestación de trabajo: los sostenedores de la teoria de la relación de trabajo nunca han afirmado, y tampoco es la tesis prevalente em la Ley nueva, que no pueda existir o que nunca existe un acuerdo prévio de voluntad para la formación de la relación; por lo contrario, la frase del art. 20, "cualquiera que sea e lacto que le dé origen", señala la possibilidad de ese acuerdo". In $E l$ nuevo derecho mexicano del trabajo: historia, princípios fundamentales, derecho individual y trabajos especiales. Mexico: Editorial Porrua, 1977, p. 189.

${ }^{28}$ GOMES, Orlando. GOTTSCHALK, Élson. Curso de direito do trabalho. Rio de Janeiro: Forense, 2006, pp. 143-144.

29 "São direitos dos trabalhadores urbanos e rurais, além de outros que visem à melhoria de sua condição social:.

${ }^{30}$ reconhecimento das convenções e acordos coletivos de trabalho".
} 
do vínculo de emprego tem início a partir do momento em que seus sujeitos acordam, apesar de a plenitude de sua eficácia jurídica dar-se quando o trabalhador põe em execução o seu propósito.

Por outro lado, mesmo que a prestação do trabalho seja imprescindível em diversos setores da economia, a manifestação de consentimento das partes é necessária ao nascimento do vínculo, ainda que por mera adesão. Mesmo porque, o conteúdo da relação pode estar previamente regulamentado sem que isso altere sua natureza contratual, uma vez que a atribuição de natureza contratual reside na liberdade do consentimento para a formação da relação, e não para a determinação de seu conteúdo, ao menos para Orlando Gomes e Elson Gottschalk ${ }^{31}$. Efetivamente, em cenários democráticos, em que a liberdade de ofício é consagrada como direito individual fundamental ${ }^{32}$, que impõe limites à atuação estatal, o consentimento do trabalhador não pode ser dispensado ou ignorado.

Interessa esclarecer, antes de se dar um passo adiante, que as críticas direcionadas à teoria da relação de emprego se aplicam igualmente às concepções alemã e mexicana, que não se diferem quanto aos seus conteúdos ${ }^{33}$, e à teoria institucionalista ${ }^{34}$, de origem francesa, que se exprime pela adesão à instituição, isto é, com o ingresso do trabalhador em uma determinada empresa, que era vista como superior ao indivíduo e que possuía atividade normativa, constrangendo todos àqueles que lhe prestassem trabalho subordinado $^{35}$.

Cumpre fazer menção à teoria acontratualista cujas bases repousavam na indiferença da existência ou não de contrato para que se verificasse a relação de emprego, de maneira que não o nega, mas também não o entende como indispensável. Para essa teoria o ingresso do empregado na empresa é ato-condição para a incidência do Direito do

\footnotetext{
${ }^{31}$ GOMES, Orlando. GOTTSCHALK, Élson. Curso de direito do trabalho. Rio de Janeiro: Forense, 2006, pp. $145-147$.

32 “Art. $5^{\circ}$ (...) XIII - é livre o exercício de qualquer trabalho, ofício ou profissão, atendidas as qualificações profissionais que a lei estabelecer".

33 "A concepção de Mario de La Cueva sobre a relação de trabalho ou a do contrato-realidade não é senão uma variante infeliz das idéias acima condensadas". In GOMES, Orlando. GOTTSCHALK, Élson. Curso de direito do trabalho. Rio de Janeiro: Forense, 2006, p. 144.

34 "O institucionalismo correspondeu a um movimento desenvolvido na França que percebeu na empresa um poder organizado e estruturado segundo as regras de autoridade. Enquanto nos contratos prevalece o critério de igualdade entre as partes, na relação institucionalista há superioridade jurídica da instituição que exerce seu poder com autoridade em relação aos seus empregados”. In: CASSAR, Vólia Bomfim. Direito do trabalho. 4. ed. Niterói: Impetus, 2010, p. 241.

${ }^{35}$ GOMES, op. cit., p. 146.
} 
Trabalho, ideia já explicitada por Maria de La Cueva no seio da teoria da relação de emprego, anticontratualista, como visto em linhas precedentes.

Assim, ultrapassadas as limitações dadas à relação de emprego pelas teorias anticontratualista e acontratualistas, a prestação de serviços que associa o trabalhador a um empreendimento revela-se apenas como o aspecto objetivo do fenômeno, que se caracteriza também pela avença, como sua faceta subjetiva. Dois lados de uma mesma moeda, pois.

A autonomia da vontade pode ser compreendida como o poder atribuído pela ordem jurídica aos particulares para que autorregulem suas relações, de modo que se tornam legisladores dos próprios interesses, seja na criação de direitos, seja na estipulação de deveres ${ }^{36}$. Extrai-se das dimensões da autonomia da vontade sua manifestação, com mais ou menos intensidade, nas diversas searas e institutos do Direito Privado, especialidade na qual se inserem o Direito Civil e o Direito do Trabalho. Contudo, é no âmbito dos negócios jurídicos que se concretiza a liberdade contratual, ou seja, a liberdade contratual, que é instrumentalizada em um contrato, é a manifestação por excelência da autonomia privada ${ }^{37}$.

Ocorre que esse poder de autorregramento não é absoluto e talvez nunca tenha sido, muito embora brocardos como pacta sunt servanda e contractus est lex inter partes passassem essa impressão ${ }^{38}$. Além das limitações existentes no próprio Direito Civil, encontramos o próprio Direito do Trabalho que, com o conteúdo mínimo que impõe à relação de emprego, representa restrição de grande relevo à autonomia privada. Vale registrar, com arrimo em Wilson Steinmetz, a existência de duas concepções ou pontos de problematização da autonomia privada no âmbito das relações contratuais, uma positiva, que consiste na liberdade de estipular o conteúdo dos contratos, e outra negativa, que traz a faculdade de celebrar ou não contratos ${ }^{39}$.

No Direito do Trabalho, acaba prevalecendo a faceta negativa da autonomia privada, a faculdade de contratar, mas, uma vez estabelecido o vínculo de emprego, apenas é licito a seus sujeitos a estipulação de direitos que ultrapassem beneficamente o mínimo

\footnotetext{
${ }^{36}$ STEINMETZ, Wilson. A Vinculação dos Particulares a Direitos Fundamentais. Malheiros, 2004, pp. 190191.

${ }^{37}$ Ibidem, p. 192.

${ }^{38}$ Ibidem, p. 192.

${ }^{39}$ Ibidem, p. 188.
} 
legal, o que se depreende no direito vigente do art. $7^{\circ}$, caput, da $\mathrm{CR}^{40}$ e no art. 444 da $\mathrm{CLT}^{41}$, pois, atente-se, afasta-se a autonomia da vontade exclusivamente no que diz respeito à redução do conteúdo mínimo, não ocorrendo seu afastamento para a melhoria da condição social do trabalhador por meio de direitos outros além dos estabelecidos pelas fontes estatais do Direito.

Com isso, sem que exista contrato entre as partes, expresso ou tácito, não existe relação de emprego que enseje a aplicação do Direito do Trabalho, muito embora nem todos os efeitos da relação de emprego dependam da existência do contrato ${ }^{42}{ }^{43}$. Ainda, o Direito do Trabalho limita a autonomia da vontade no que respeita às condições contratuais mínimas, em nada prejudicando as estipulações que ultrapassarem o mínimo legal ${ }^{44}$.

Em síntese, em que pese o abandono da contraposição entre contrato e relação de emprego e a adoção de uma visão que os associa como facetas de um mesmo fenômeno, sua importância não pode ser olvidada, pois a distinção conceitual pode elidir a repetição de erros, em especial a aplicação de preceitos civilistas em situações em que há incompatibilidade com os ditames próprios da relação de emprego ou mesmo uma visão exagerada sobre a liberdade de contratar que a compreenda como direito ilimitado ${ }^{45}$, o que será de extrema valia à solução de questões reservadas para as páginas seguintes deste trabalho.

\footnotetext{
40 "São direitos dos trabalhadores urbanos e rurais, além de outros que visem à melhoria de sua condição social".

41 "As relações contratuais de trabalho podem ser objeto de livre estipulação das partes interessadas em tudo quanto não contravenha às disposições de proteção ao trabalho, aos contratos coletivos que lhes sejam aplicáveis e às decisões das autoridades competentes".

${ }^{42}$ SILVA, Homero Batista Mateus da. Curso de direito do trabalho aplicado, vol. 6: contrato de trabalho. Rio de Janeiro: Elsevier, 2009, p. 9.

43 "Los intereses contrapuestos entre empresarios y trabajadores, como sujetos del contrato de trabajo, y el caráter de parte débil de estos últimos, a la hora de establecer las condiciones de trabajo, pusieron em evidencia la necesidad de equilibrar las relaciones entre ambas partes, em aras de mantener la paz social y apaciguar la cuestión social surgida". In: IDIAKEZ, Francisco Javier Arrieta. El derecho del trabajo y las relaciones jurídicas calificadas como "zonas grises". Revista de la Universidad de Deusto. Vol. 57/2, Juliodiciembre. Bilbao, 2009, p. 307

${ }^{44}$ SÜSSEKIND, Arnaldo. Institutições de direito do trabalho. Volume I. 22. ed. atual. Por Arnaldo Süssekind e João de Lima Teixeira Filho. São Paulo: LTr, 2005, p. 252.

${ }_{45}$ ALEXY, Robert. Teoria dos Direitos Fundamentais. Tradução de Virgílio Afonso da Silva da $5^{\text {a }}$ edição alemã. Malheiros, 2008, p. 343.
} 


\section{O nascimento da relação de emprego. O negócio jurídico como causa da relação de emprego com a Administração Pública.}

$\mathrm{Na}$ esteira dos ensinamentos de Marcos Bernardes de Mello, que expõem os pensamentos de Savigny, Santoro Passarelli e Pontes de Miranda, pode-se conceituar o fato jurídico como acontecimento que pode criar, modificar ou extinguir relações jurídicas ${ }^{46}$. É nesse sentido que se afirma que nem todos os fatos que acontecem no dia a dia repercutem na esfera jurídica, apenas aos fatos que interferem de maneira significante nas relações sociais é que o Direito empresta efeitos, convertendo-os em fatos jurídicos. Em suma, para as relações jurídicas interessam os fatos jurídicos constitutivos, isto é, aqueles que constituem relações jurídicas, implicando a criação ou a aquisição de direitos ${ }^{47}$.

Incumbe ao fato jurídico tornar efetiva a relação prevista no ordenamento. $\mathrm{Na}$ verdade, nenhuma norma jurídica pode deixar o campo abstrato da previsão normativa e se tornar realidade sem que intervenha um fato jurídico idôneo, segundo a lei, para que produza seus resultados ${ }^{48}$. Desse modo, não é por virtude própria que o fato passa a ter natureza jurídica, mas sim em razão de sua inserção na estrutura do Direito, ou seja, é pela incidência das normas que as ocorrências do mundo físico se qualificam como fatos jurídicos $^{49}$. Nesse sentido, o fato jurídico preexiste à relação jurídica, dando-lhe origem ${ }^{50}$.

Por outro lado, não há relação de exclusividade entre fatos jurídicos e condutas humanas, o que possibilita que eventos da natureza também possam, de acordo com previsões normativas, receber a qualificação de fatos jurídicos ${ }^{51}$, como a chuva que causa enchentes e mortes, um incêndio etc. No caso específico da relação de emprego, apenas as condutas humanas podem the dar nascedouro, pois, como destacado, ela pressupõe a existência de sujeitos bem definidos e a manifestação de vontades convergentes voltadas à prestação de serviços. Vale dizer, o trabalho prestado nos termos dos arts. $2^{\circ}$ e $3^{\circ}$ da CLT constitui o fato idôneo à formação da relação de emprego, de modo que os termos estabelecidos nesses dispositivos são chamados de elementos de existência.

\footnotetext{
${ }^{46}$ MELLO, Marcos Bernardes de. Teoria do fato jurídico: plano da existência. 16. e.d. São Paulo: Saraiva, 2010 , pp. 111 a 113.

${ }^{47}$ ANDRADE, Manuel A. Domingues. Teoria Geral da Relação Jurídica. Vol I: sujeito e objeto. Coimbra: Livraria Almedina, 2003, p. 21.

${ }^{48}$ Ibidem, p. 22.

${ }^{49}$ LORENZETTI, Ari Pedro. As nulidades o direito do trabalho. 2.ed. São Paulo: LTr, 2010, p. 23.

${ }^{50}$ COSTA, Wille Duarte. Conceito e estrutura da relação jurídica. Revista da Faculdade de Direito Milton Campos. 1 v. Belo Horizonte, 1994, p. 297.

${ }^{51}$ LORENZETTI, op. cit., p. 23.
} 
Com efeito, a previsão abstrata da lei se tornará realidade a partir do momento em que o fato jurídico que lhe dá existência for verificado, o que não representa necessariamente sua conformidade com os ditames legais. Questões de fiel observância das exigências legais quanto à capacidade, objeto e forma, por exemplo, são discussões próprias da validade da relação de emprego e da generalidade das relações jurídicas, não se confundindo, pois, com os elementos de existência, distinção que será esclarecida oportunamente $^{52}$.

Entre as diversas espécies de fatos, interessa-nos aqueles que derivam da vontade humana, isto é, os que dependem da consciente atuação dos sujeitos para que aconteçam. São os denominados atos jurídicos lato $\operatorname{sensu}^{53}$, que se subdividem em atos jurídicos stricto sensu e negócios jurídicos.

Passemos à distinção.

Existem atos cujas consequências estão completamente regulamentadas pela lei, inexistindo espaço para que a vontade dos sujeitos as molde, os quais recebem o nome de atos jurídicos stricto sensu ou atos jurídicos não negociais. Logo, o ato jurídico em sentido estrito possui por característica um comportamento humano consciente adotado para deflagrar os efeitos previstos em $1 \mathrm{ei}^{54}$.

\footnotetext{
${ }^{52}$ Segundo Ari Pedro Lorenzetti "no confronto entre a hipótese normativa abstrata e o fato social concreto, pode haver uma relação de desarmonia mais ou menos intensa, mas suficiente para impedir a superveniência dos efeitos jurídicos esperados. Em primeiro lugar, pode ocorrer que o fato sequer preencha as condições para ser tratado como jurídico, ou seja, é possível que nem mesmo ingresse no mundo jurídico, por lhe faltar algum dos elementos que o qualifiquem como jurígeno. Por outro lado, ainda que seja considerado como fenômeno jurídico, pode o fato não ser apto a produzir os efeitos desejados. Na primeira situação, estamos diante de um fato não jurídico, ou apenas aparentemente jurídico, isto é, um fato juridicamente inexistente. $\mathrm{Na}$ segunda hipótese, haverá um fato jurídico, porém deficiente, imperfeito, falho". In: LORENZETTI, Ari Pedro. As nulidades o direito do trabalho. 2.ed. São Paulo: LTr, 2010, p. 28.

53 "Denomina-se ato jurídico o fato cujo suporte fático preveja como cerne uma exteriorização consciente de vontade, que tenha por objeto obter um resultado juridicamente protegido ou não proibido e possível". In: MELLO, Marcos Bernardes de. Teoria do fato jurídico: plano da existência. 16. e.d. São Paulo: Saraiva, 2010, p. 145.

${ }^{54}$ Ari Pedro Lorenzetti professa que "os efeitos dos atos jurídicos, no entanto, nem sempre são previsto exaustivamente pelas normas estatais. Existem determinados atos cujas consequências dependem da vontade de seus agentes, não os regulamenta a lei de forma precisa e cabal. Quando os efeitos resultantes do ato são apenas os que a lei prevê, temos o chamado ato jurídico stricto sensu, ou ato jurídico não negocial. $O$ ato jurídico em sentido estrito caracteriza-se, assim, por ser um comportamento humano e consciente adotado para deflagar os efeitos previamente estabelecidos em lei. Existe nele manifestação de vontade (vontade simples), mas falta o caráter de autoregramento (vontade qualificada), uma vez que quem determina seus efeitos não são as partes, mas exclusivamente a lei. Diante disso, "os atos jurídicos stricto sensu são incondicionáveis, inatermáveis e não podem ter seus efeitos vinculados a modos ou encargos, exatamente porque neles a vontade não tem escolha de categoria jurídica, limitando-se à prática do ato". In: LORENZETTI, op. cit., p. 25.
} 
Porém, nos casos em que os efeitos dos atos lato sensu dependam, ainda que parcialmente ou apenas em tese, da autonomia dos sujeitos que deles fazem parte, passam a ser denominados como negócios jurídicos. A imposição de restrições legais à vontade dos sujeitos $^{55} 56$ e a predominância de uma das partes no estabelecimento das regras da avença não descaracterizam a natureza negocial desses atos, desde que exista algum espaço para a manifestação da autonomia da vontade das partes.

A análise do fato que dá origem à relação de emprego revela a existência de espaço para a autonomia privada dos sujeitos, isto é, do empregado e do empregador. Aliás, extrai-se o reconhecimento da autorregulamentação do art. $7^{\circ}$, caput, da $\mathrm{CR}$, ao declarar que os direitos consagrados no Texto Magno constituem somente um patamar mínimo, de observância obrigatória, que não afasta, nem pretende afastar, a concessão de outros direitos estabelecidos pelas próprias partes.

O dirigismo estatal, marcado pela imposição de direitos mínimos na relação de emprego, cumpre a especial função de conferir dignidade ao trabalho, de maneira a obstar trabalhos em condições animalescas, bem como a instrumentalização do cidadão trabalhador. Destaque-se, porém, que a estipulação de conteúdo mínimo não é peculiaridade do Direito do Trabalho, sendo encontrada também em outros ramos, como o Direito do Consumidor ${ }^{57}$ e o Direito Civil ${ }^{58}$.

\footnotetext{
${ }^{55}$ Registra Ari Pedro Lorenzetti que "quando, porém, os efeitos do atos jurídicos inserem-se, ainda que parcialmente ou apenas em tese, na autonomia privada dos sujeitos que dele tomam parte, o ato jurídico é também chamado de negócio jurídico, ou ato jurídico negocial. O fato de a lei impor restrições à autonomia da vontade, em relação a certos aspectos do ato, não é suficiente para descaracterizá-lo como sendo negocial, desde que haja nele algum espaço para a autorregulamentação das partes, ainda que apenas uma delas dite as regras e à outra caiba somente aceitar ou não as condições propostas. Afinal, em qualquer caso, a vontade negocial há de conformar-se aos limites traçados pelo ordenamento jurídico, não sendo, portanto, completamente livre. Como qualquer outro ato jurídico, pois, o negócio (e a vontade que o apoia) não produz efeitos por si mesmo, senão na medida em que o ordenamento jurídico o reconhece e lhe empresta a própria força. Todavia, enquanto nos atos jurídicos não negociais a eficácia dimana exclusivamente da lei (ex lege), a eficácia dos negócios jurídicos depende das disposições das partes". In: LORENZETTI, Ari Pedro. As nulidades o direito do trabalho. 2.ed. São Paulo: LTr, 2010, p. 26.

${ }^{56}$ Antônio Junqueira de Azevedo professa que "sendo o negócio jurídico uma espécie de fato jurídico, também o seu exame pode ser feito nesses dois planos. Entretanto, e essa é a grande peculiaridade do negócio jurídico, sendo ele um caso especial de fato jurídico, já que seus efeitos estão na dependência dos efeitos que foram manifestados com queridos...". In: AZEVEDO, Antônio Junqueira de. Negócio jurídico: existência, validade e eficácia. 4. ed. atual. de acordo com o novo Código Civil (Lei n. 10.406, de 10-1-2002). São Paulo: Saraiva, 2002, p. 24.

${ }^{57}$ Encontram-se no art. $6^{\circ}$ do Código de Defesa do consumidor um rol de direitos que indica a atuação do dirigismo estatal, aqui utilizada sem qualquer cunho pejorativo.

${ }^{58} \mathrm{O}$ tratamento jurídico dado ao casamento pelo Código Civil, Livro IV, Subtítulo I, revela a existência de diversas normas que impõem conteúdos ou procedimentos ao instituto jurídico em relevo.
} 
Entendidos esses conceitos, cumpre identificar a espécie de ato jurídico lato sensu que dá ensejo à relação de emprego com as empresas estatais, sociedades de economia mista e empresas públicas, que integram Administração Pública Indireta e possuem personalidade jurídica de Direito Privado.

É bem verdade que os empregos públicos seguem, em geral, as diretrizes estabelecidas em lei ou no edital que ampara o concurso público, que, necessariamente, deve preceder a contratação, singularidade que não elide a possibilidade de as empresas estatais ampliarem, por meios devidos, os direitos conferidos àqueles que se vinculam ao serviço público sob o regime celetista. Por outro lado, é certo que a Administração Pública possui como um de seus princípios vetores, contidos no art. 37, caput, da CR, o princípio da legalidade, que lhe impõe a estrita atuação de acordo com os ditames legais.

Veja-se, a título de exemplo, o que ocorre com as empresas estatais integrantes da Administração Pública Federal.

A Medida Provisória n 1.499-33, de 29 de novembro de 1996, especificamente em seu art. 28, II, criou o Conselho de Coordenação e Controle das Empresas Estatais, atual Departamento de Controle de Empresas Estatais, que possui atribuição para aprovar parâmetros para a política salarial, de benefícios e de vantagens de empregados das empresas estatais, incumbência exercida por meio da Resolução $n^{\circ}$ 09/1996, que possibilitou a concessão de direitos e aumentos salariais sem a necessidade de lei em sentido estrito, revelando, pois, a adoção do regime negocial pelas empresas estatais.

Por conseguinte, o contrato de trabalho pode ser classificado como relação jurídica de natureza negocial, independentemente de quem figure como empregador. Todavia, cumpre esclarecer que a regular vinculação dos cidadãos com a Administração Pública dá-se por meio de concurso público, procedimento formado por diversos atos administrativos, que resulta, no caso de empresas estatais, em uma vinculação de natureza negocial. A participação do trabalhador no concurso público restringe-se à manifestação de sua vontade em participar do certame, inexistindo espaço para que o conteúdo do processo de escolha seja determinado por seus candidatos, isso em razão da submissão dos concursos públicos às normas constitucionais e ordinárias e como decorrência da peculiaridade de o candidato somente ter acesso ao teor do edital após sua publicação. 
Com amparo nas considerações precedentes, pode-se afirmar que o concurso público refere-se ao procedimento de natureza não negocial que pode dar ensejo à relação de emprego com empresas estatais, o que, ainda, autoriza dizer, como adiante de detalhará, que esse procedimento também ocupa a natureza de pressuposto formal do contrato de trabalho com entes da Administração Pública. Realçamos que a existência de atos de Direito Público que formam relações de cunho negocial é reconhecida pela doutrina, como Clóvis V. do Couto e Silva, que se refere a esses atos ao tratar de "contrato ditado", requisições administrativas de serviços e de bens de particulares ${ }^{59}$. De todo modo, o ponto de destaque reside na ausência de alteração da natureza da relação estabelecida em razão de ser precedida por atos administrativos ou, por outro olhar, por procedimentos que constituem a forma do negócio jurídico.

Veja-se, nos limites já expostos, que o conteúdo trabalhista da relação jurídica pode ser fixado ou alterado, para além do conteúdo mínimo, por seus sujeitos. Portanto, efetivamente, não há se confundir o tipo de ato que cria o vínculo de trabalho com a natureza do próprio vínculo estabelecido.

Após esclarecimentos necessários acerca das empresas estatais, pode-se afirmar que todos os atos jurídicos em sentido estrito e os negócios jurídicos assentam-se nos seguintes elementos: sujeito, objeto, vontade, forma, situação no tempo, no espaço e causa $^{60}$. Mas, frisa-se, que não se devem confundir os elementos do negócio jurídico, que demarcam sua existência com os pressupostos de validade, peculiaridades que revelam a conformidade, ou não, do ato com a ordem jurídica. Como relata Ari Pedro Lorenzetti, é corriqueira a confusão entre os elementos e os requisitos ou pressupostos do negócio jurídico, quando, por exemplo, se afirma que é impossível o reconhecimento de vínculo de emprego nos casos em que o trabalhador não se submeteu ao prévio concurso público, nas situações em que sua observância é imperiosa, ou quando se afirma que não se forma relação de emprego entre a empresa que explora atividade criminosa e o obreiro. A rigor, o que define a existência do ato ou negócio jurídico é a presença de seus elementos constitutivos, de modo que eventual vício em seus pressupostos, que não se confundem com os elementos de existência, repercute exclusivamente em sua validade ${ }^{61}$.

\footnotetext{
${ }^{59}$ SILVA, Clóvis V. do Couto e. A obrigação como processo. Rio de Janeiro: Editora FGV, 2007, pp. 78-79.

${ }^{60}$ LORENZETTI, Ari Pedro. As nulidades o direito do trabalho. 2.ed. São Paulo: LTr, 2010, p. 29.

${ }^{61}$ Ibidem, p. 30.
} 
Não obstante essas considerações, impende mencionar a identificação de elementos de existência e pressupostos de validade dos atos administrativos, espécies de atos jurídicos, adotada por Celso Antônio Bandeira de Mello e defendida por Weida Zancaner. Em consonância com essa vertente, conteúdo, forma e objeto são os elementos de existência do ato administrativo, visto que dizem respeito àquilo sobre o que o ato dispõe e à sua exteriorização, determinando, assim, sua perfeição ${ }^{62}$. No que se refere à validade, o entendimento em relevo ampara-se na compreensão Kelseniana de que o fundamento de validade de uma norma reside em outra norma, designada por norma superior $^{63}$. Ainda, para demarcar a correção do ato administrativo de acordo com normas superiores, destaca linha doutrinária indica como pressupostos de validade os sujeitos, o motivo, os requisitos procedimentais, a finalidade, a causa e as formalidades ${ }^{64}$.

Por fim, sem prejuízo da riqueza das distinções extraída da pluralidade de entendimentos sobre os elementos de existência e pressupostos de validade, optamos no presente trabalho pela compreensão mais ampla esclarecida nas linhas iniciais deste subtópico, porquanto se refere à generalidade dos atos jurídicos, não se restringindo aos atos administrativos.

\section{Contornos gerais de uma relação jurídica de emprego.}

Deixados para trás os marcos históricos e doutrinários que sustentavam a radical segregação entre relação e contrato de trabalho, bem como estabelecida a natureza negocial do contrato de emprego firmado com as integrantes da Administração Pública Indireta que possuem personalidade jurídica de Direito Privado, especificamente as empresas estatais, faz-se necessário entender o que é uma relação jurídica, de maneira a se identificarem os elementos que a integram e, ainda, as repercussões de suas ausências.

Manuel A. Domingues de Andrade identifica diversos sentidos para o termo relação jurídica. Em sentido amplo, ele representa toda situação da vida juridicamente relevante, isto é, apta a produzir consequências jurídicas. Em uma acepção mais estrita, o

\footnotetext{
62 ZANCANER, Weida. Da convalidação e da invalidação dos atos administrativos. 2.ed. $3^{\mathrm{a}}$ tiragem 03.2001. São Paulo: Malheiros, 2008, pp. 36-37.

${ }^{63}$ Ibidem, p. 41.

${ }^{64}$ Ibidem, p. 47.
} 
autor em relevo identifica a relação jurídica como toda relação da vida social disciplinada pelo Direito e revestida de uma fisionomia típica ${ }^{65}$.

Os institutos jurídicos, que são a disciplina jurídica de uma dada relação em abstrato, não se confundem com as relações jurídicas, muito embora possuam grande proximidade, a ponto de constituírem dois aspectos da mesma realidade. Essa proximidade não deve dar ensejo a confusões, pois a relação jurídica constitui o objeto regulado, ao passo que o instituto representa a regulamentação ou a disciplina jurídica da relação ${ }^{66}$.

De modo diverso não ocorre com a relação jurídica de emprego, que pode ser analisada em si e também de acordo com as diversas normas que lhe digam respeito. $\mathrm{O}$ conjunto de normas jurídicas próprias da relação de emprego é encontrado em sua preponderância na CLT, mas há diversas normas que possuem como objeto a relação em relevo, como ocorre com as leis que versam sobre gratificação natalina ${ }^{67}$, fundo de garantia por tempo de serviço ${ }^{68}$ e seguro-desemprego ${ }^{69}$.

Além das normas de Direito ordinário, a CR de 1988 possui um extenso rol de direitos em seu art. $7^{\circ}$. Ocorre especial incidência da regulamentação constitucional nas relações de emprego entre os trabalhadores e a Administração Pública, preceituando-se normas específicas sobre servidores públicos, aplicáveis mesmo que os entes públicos adotem, quanto ao pessoal, regime jurídico não estatutário, gerando, assim, certo hibridismo de institutos.

Pois bem. Pode-se dizer que os elementos da relação de emprego são os dados que a compõem, suas partes integrantes, aquelas circunstâncias sem as quais ela não pode $\operatorname{existir}^{70}$.

\footnotetext{
65 ANDRADE, Manuel A. Domingues. Teoria Geral da Relação Jurídica. Vol I: sujeito e objeto. Coimbra: Livraria Almedina, 2003, p. 2.

${ }^{66}$ Ibidem, p. 5.

${ }^{67}$ Lei n. ${ }^{\circ} 4.090$ de 13 de julho de 1962.

${ }^{68}$ Lei n. ${ }^{\circ} 8.036$ de 11 de maio de 1990.

${ }^{69}$ Lei n. $^{\circ} 7.998$ de 11 de janeiro de 1990.

${ }^{70}$ Mario De La Cueva, com os olhos voltados ao Direito mexicano, destaca "los elementos de una relación son los dados que la componen, sus partes integrantes, para dicirlo así, sin las cuelas no puede existir. Admitido este ponto de vista, si analizamos la definición del art. 20, encontramos que en ella se hace referencia a cuatro nociones: a) Dos personas, una de las cuales tiene el caráter de trabajador y la outra el de patrono, dos concepttos que ya nos son conocidos; b) Una prestación de trabajo, termino que también conocemos; c) La característica que acompaña a la prestación de trabajo, a la que la Ley ha dado el nombre de subordinación; d) El salario, que según el art. 82, es "la retribuición que debe pagar el patrono al trabajador por su trababajo". Si no existen el primero de los elementos, esto es, la presencia de un trabajador y um patrono, y el segundo, o sea, la prestación de trabajo, no puede darse la relación laboral, pues ésta consiste en la prestación de trabajo que realiza uma persona para outra”. In: El nuevo derecho mexicano del
} 
Sob outra perspectiva, Manuel A. Domingues de Andrade compara a relação jurídica com uma linha que possui em cada uma de suas extremidades as pessoas entre as quais se estabelece ${ }^{71}$. Ela, ainda, possui um objeto, que pode ser uma coisa ou uma atividade. Igualmente, a relação deriva de determinada causa ou, se se preferir, de determinado fato ou ocorrência a que a lei atribui efeito. Há, também, a garantia, que configura a predisposição de meios coercitivos que possibilitem a realização efetiva da relação jurídica, o que a distingui de outras relações que impõem deveres de conduta, como a religiosa e a moral. Contudo, o ponto central de uma relação jurídica é o nexo mediante o qual os sujeitos se vinculam ${ }^{72}$.

Diante de tudo que foi dito, pode-se identificar a relação jurídica como a vinculação entre dois sujeitos em torno de um objeto, pela qual se estabelecem diversos direitos e obrigações para os envolvidos, que possui como origem algum fato jurídico e que possui meios coercitivos que possibilitem sua efetiva realização.

Perceba-se que as relações jurídicas podem nascer a partir de atos ou negócios jurídicos, espécies de fatos jurídicos. A ligação entre os termos, de causa e consequência, faz com que ambas possam ser analisadas à luz do preenchimento dos elementos de existência e dos pressupostos de validade, que representam, em última análise, a correspondência da relação real com a idealizada pelas normas jurídicas.

Desse modo, a relevância do estudo dos elementos de existência repousa na necessidade de se verificar se determinada conduta, no caso do Direito do Trabalho necessariamente humana, é regulamentada pela ordem jurídica, ou seja, se ela é reconhecida pelo Direito como ato jurídico lato sensu, capaz de criar, modificar ou extinguir relações jurídicas. Igualmente, é indispensável a identificação dos elementos que tornam jurídicos determinados atos humanos, pois sem eles os comportamentos seriam irrelevantes para o ordenamento normativo, vale dizer, seriam juridicamente inexistentes ${ }^{73}$.

Do cotejo das diversas relações jurídicas é possível identificar elementos gerais, que são comuns a todas as relações jurídicas e os elementos categoriais, próprios de cada

trabajo: historia, princípios fundamentales, derecho individual y trabajos especiales. Mexico: Editorial Porrua, 1977, p. 199.

${ }^{71}$ ANDRADE, Manuel A. Domingues. Teoria Geral da Relação Jurídica. Vol I: sujeito e objeto. Coimbra: Livraria Almedina, 2003, p. 6.

${ }^{72}$ ANDRADE, loc. cit.

${ }^{73}$ LORENZETTI, Ari Pedro. As nulidades o direito do trabalho. 2.ed. São Paulo: LTr, 2010, p. 31. 
tipo de relação ${ }^{74}$. Veja-se que, transferidos esses conceitos para o Direito do Trabalho, podem-se identificar como elementos gerais ${ }^{75}$ o objeto, a forma, o sujeito, a situação no tempo e no espaço, a causa e a vontade e, como elemento categorial, a subordinação, que caracteriza, em especial, a relação de emprego ${ }^{76}{ }^{77}$, uma vez que outras características como pessoalidade, não eventualidade (habitualidade) e recebimento de contraprestação também podem ser verificados em outras relações jurídicas, por exemplo, nos contratos de prestação de serviços $^{78}$ e empreitada ${ }^{79}$.

No Direito do Trabalho brasileiro, os elementos da relação da relação de emprego estão consagrados nos arts. $2^{\circ}$ e $3^{\circ}$ da CLT. Eis a redação dos dispositivos:

“Art. $2^{\circ}$ Considera-se empregador a empresa individual ou coletiva, que, assumindo os riscos da atividade econômica, admite, assalaria e dirige a prestação pessoal de serviços".

“Art. $3^{\circ}$ Considera-se empregado toda pessoa física que prestar serviços de natureza não eventual a empregador, sob a dependência deste e mediante salário".

Depreende-se do conteúdo das proposições transcritas que a relação de emprego é composta dos seguintes elementos: a figura do empregado, do empregador, trabalho não

\footnotetext{
${ }^{74}$ CRUZ, Alexandre Corrêa da. Os efeitos da contratação sem concurso pelo ente público: da impropriedade do enunciado 363 do TST. Disponível em: 〈http://www.femargs.com.br/revista03_cruz.html〉. Acesso em 14.12.2012.

${ }^{75}$ Há, também, como elemento geral a garantia, isto é, a possibilidade de socorrer dos órgãos do Estado para ver garantidos dos direitos ou do objeto da relação jurídica. Singela previsão legal no sentido de que as obrigações assumidas devem ser cumpridas é insuficiente a assegurar a observância dos direitos próprios da relação jurídica, Em razão dessa debilidade, o Estado, possuidor do monopólio da utilização da força, impõe sanções exteriores aos violadores dos direitos decorrentes da relação jurídica. Às providências adotáveis pelo Estado dá-se o nome de garantias da relação jurídica. Assim, garantia da relação jurídica é o conjunto de meios sancionatórios adotáveis pelo Estado, por meio dos Tribunais, contra o sujeito da relação jurídica nas hipóteses em que ele não cumpre espontaneamente o comportamento prescrito. In ANDRADE. Manuel A. Domingues. Teoria Geral da Relação Jurídica. Vol I: sujeito e objeto. Coimbra: Livraria Almedina, 2003, p. 24. Registra-se, ainda, sobre a garantia que a possibilidade de o sujeito ativo exigir do sujeito passivo o cumprimento do dever jurídico deriva do vínculo jurídico, vale dizer, da ligação reconhecida pelo direito que vincula os sujeitos da relação de emprego. É nesse sentido que também se afirma que o vínculo jurídico tem assento e base em norma jurídica, ademais, é justamente na coercibilidade da norma jurídica que repousa sua distinção das demais normas de ordem social. In: COSTA, Wille Duarte. Conceito e estrutura da relação jurídica. Revista da Faculdade de Direito Milton Campos. 1 v. Belo Horizonte, 1994, p. 307.

${ }_{76}$ AZEVEDO, Antônio Junqueira de. Negócio jurídico: existência, validade e eficácia. 4. ed. atual. de acordo com o novo Código Civil (Lei n. 10.406, de 10-1-2002). São Paulo: Saraiva, 2002, p. 32.

${ }^{77}$ CATHARINO, José Martins.Compêndio de Direito do Trabalho. vol. I, 3a. ed. Editora Saraiva, São Paulo, 1982, pp.198-214.

78 "Código Civil. Art. 593. A prestação de serviço, que não estiver sujeita às leis trabalhistas ou a lei especial, reger-se-á pelas disposições deste capítulo.

Art. 594. Toda a espécie de serviço ou trabalho lícito, material ou imaterial, pode ser contratada mediante retribuição".

79 "Código Civil. Art. 610. O empreiteiro de uma obra pode contribuir para ela só com seu trabalho ou com
} ele e os materiais". 
eventual, oneroso, prestado com subordinação, pessoalidade e sob a direção de outrem ${ }^{80}$. Além desses, há, ainda, a vontade, a causa, a situação no tempo e no espaço.

Apesar de a relação de emprego possuir elementos de existência, é possível que o negócio jurídico que lhe dá causa aconteça em desconformidade com a ordem jurídica, o que gerará uma série de consequências, em especial, quanto à produção de efeitos, surgindo, dessa maneira, a necessidade de se identificarem as exigências estabelecidas pelo Direito para o tipo de negócio jurídico escolhido, que consistem nos pressupostos de validade $^{81}$.

Com efeito, os pressupostos de validade são qualidades de que devem se revestir os elementos de existência do negócio jurídico para que seja regular ${ }^{82}$, o que implica dizer que cada um dos elementos do negócio jurídico encontra correspondência com um pressuposto que ateste sua consonância com as normas jurídicas. Há, pois, um paralelismo entre os elementos e os pressupostos ${ }^{83}$.

Tem-se, com isso, que presentes os elementos gerais, sujeito, objeto e forma, e o elemento categorial, a subordinação, estaremos frente a uma relação de emprego e, atendidas as exigências legais, estaremos diante de uma relação de emprego válida. Todavia, simples menção aos elementos e aos pressupostos é insuficiente à compreensão da relação de emprego, o que empolga o enfrentamento de cada um deles, nos limites das dimensões e dos objetivos do presente trabalho.

\footnotetext{
${ }^{80}$ Maurício Godinho Delgado afirma "a proposição de método oriunda das Ciências Sociais, informadora de que "todo fenômeno sócio-histórico resulta da síntese de múltiplas determinações”, socorre, uma vez mais, o estudioso do Direito na pesquisa acerca da formação e caracterização da figura jurídica da relação de emprego. De fato, a relação empregatícia, enquanto fenômeno sociojurídico, resulta da síntese de um diversificado conjunto de fatores (ou elementos) reunidos em um dado contexto social interpessoal. Desse modo, o fenômeno sociojurídico da relação de emprego deriva da conjugação de certos elementos inarredáveis (elementos fático-jurídicos), sem os quais não se configura a mencionada relação. Os elementos fático-jurídicos componentes da relação de emprego são cinco:a) prestação de trabalho por pessoa física a um tomador qualquer; b) prestação efetuada com pessoalidade pelo trabalhador; c)também efetuado com não eventualidade; d)efetuada sob subordinação ao tomador dos serviços; e)prestação de trabalho efetuado com onerosidade". In: DELGADO, Mauricio Godinho. Curso de direito do trabalho. 10. ed. São Paulo: LTr, 2011, p. 279.

${ }^{81}$ Valemo-nos da terminologia empregada por Marcos Bernardes de Mello no que se refere à utilização da expressão elementos para se referir ao plano da existência e pressupostos para ao plano da validade. In: MELLO, Marcos Bernardes de. Teoria do fato jurídico: plano da existência. 16. e.d. São Paulo: Saraiva, 2010.

${ }^{82}$ LORENZETTI, Ari Pedro. As nulidades o direito do trabalho. 2.ed. São Paulo: LTr, 2010, p. 41.

83 "Código Civil. Art. 104. A validade do negócio jurídico requer: I - agente capaz; II - objeto lícito, possível, determinado ou determinável; III - forma prescrita ou não defesa em lei”.
} 


\section{Sujeitos da relação de emprego.}

Identificam-se no eixo direito-dever os sujeitos da relação de emprego: em uma de suas extremidades está o empregado e, na outra, o empregador. Os sujeitos da relação de emprego possuem denominação e características próprias, bem como, no sentido jurídico da expressão, susceptibilidade de direitos e obrigações ${ }^{84}{ }^{85}$. Não se pode olvidar, contudo, que essa susceptibilidade somente pode ser concedida pelo Direito, que o fez não apenas aos homens individualmente considerados, mas, também, a atribuiu a organizações por eles criadas para tutelar interesses de coletividades ${ }^{86}$.

Chama-se de empregado o sujeito ativo da relação de emprego, o detentor de uma série de direitos próprios dessa relação e, essencialmente, o dono da força de trabalho que será colocada à disposição de outrem. Muito embora pessoas naturais e pessoas jurídicas sejam detentoras de personalidade jurídica $^{87}$, apenas aquelas podem figurar como empregadas, peculiaridade estatuída pelo art. $3^{\circ}$ da CLT, ao normatizar que "considera-se empregado toda pessoa física...”.

Portanto, a presença de pessoa jurídica como prestadora do trabalho descaracterizará a relação jurídica em exame, podendo configurar alguma das relações jurídicas próprias do Direito Civil, como a prestação de serviço e a empreitada.

Em relação ao elemento subjetivo da relação jurídica de emprego, interessa realçar a capacidade e a legitimidade. A capacidade desdobra-se em capacidade de direito, que decorre da própria personalidade, e capacidade de fato que representa a possibilidade de exercer poderes e faculdades decorrentes dessa condição. Dá-se a capacidade de fato nos vínculos de emprego a partir dos dezesseis anos, ressalvada a situação do aprendiz, que

\footnotetext{
${ }^{84}$ ANDRADE. Manuel A. Domingues. Teoria Geral da Relação Jurídica. Vol I: sujeito e objeto. Coimbra: Livraria Almedina, 2003, p. 19.

85 "Código Civil. Art. $1^{\circ}$ Toda pessoa é capaz de direitos e deveres na ordem civill".

${ }^{86}$ ANDRADE. op. cit., p. 20.

87 Wille Duarte Costa esclarece a respeito da personalidade jurídica que "a noção jurídica pessoa não coincide com a noção comum, pois para o direito pessoa há de ser aquela dotada de personalidade jurídica, consubstanciada na aptidão para adquirir direitos e obrigações. A personalidade aqui referida não é dada somente aos homens, pessoas naturais ou físicas, seres individualizados física e psiquicamente, capazes de vontade e ações próprias. Outros entes, por eles criados, são dotados também de personalidade. Assim sendo, além dos homens - pessoas físicas, o direito procurou dotar de personalidade certos entes, como as sociedades, as associações, as fundações e outros entes chamados de pessoas jurídicas, também capazes de direitos e de obrigações. Além disso, determinados patrimônios ou agregados patrimoniais são "personalizados", para que possam atingir alguns resultados práticos, como são os casos do espólio e da massa falida. Embora não possa ter tais agregados como pessoas, é fora de dúvida que podem ser sujeitos da relação jurídica”. In: COSTA, Wille Duarte. Conceito e estrutura da relação jurídica. Revista da Faculdade de Direito Milton Campos. 1 v. Belo Horizonte, 1994, p. 299.
} 
é uma relação de emprego especial, em que a capacidade tem início aos quatorze anos. Por sua vez, a legitimidade diz respeito à posição assumida pelo sujeito em negócios em particular, de maneira que, apesar de possuir capacidade de direito e de fato, a pessoa não pode praticar determinados atos negociais ${ }^{88}$, como se passa com o policial militar e com outros servidores que se vinculam, em regime de exclusividade, à Administração Pública, os quais, muito embora sejam dotados de capacidade, não podem, porque ilegítimos, celebrar contrato de emprego ${ }^{89}$.

No que se refere à figura do empregador, a redação do art. $2^{\circ}$ da CLT, ao fazer referência ao conjunto de bens ou à empresa, pode sugerir que esses bens ocupariam um dos polos da relação de emprego. A adoção desse entendimento possui o inconveniente ou a atecnia de conferir personalidade jurídica à figura distinta daquelas mencionadas nos $\operatorname{artigos} 2^{\circ}{ }^{90}, 44^{91}$ e $45^{92}$ do Código Civil.

Em busca de compatibilidade, poderia ser adotada a figura de sujeitos de direito, de maior alcance do que a personalidade, uma vez que compreende, também, certos patrimônios, de modo a conferir-lhes autorização para celebrar certos negócios jurídicos e, até mesmo, para figurar em relações processuais. Todavia, a nosso ver, a melhor interpretação do art. $2^{\circ}$ da CLT é aquela que verifica em suas preposições, tão somente, a

\footnotetext{
${ }^{88}$ LORENZETTI, Ari Pedro. As nulidades o direito do trabalho. 2.ed. São Paulo: LTr, 2010, p. 42.

89 "SUM-386 POLICIAL MILITAR. RECONHECIMENTO DE VÍNCULO EM-PREGATÍCIO COM EMPRESA PRIVADA (conversão da Orientação Jurisprudencial no 167 da SBDI-1) - Res. 129/2005, DJ 20, 22 e 25.04.2005. Preenchidos os requisitos do art. $3^{\circ}$ da CLT, é legítimo o reconhecimento de relação de emprego entre policial militar e empresa privada, independentemente do eventual cabimento de penalidade disciplinar prevista no Estatuto do Policial Militar. (ex-OJ nº 167 da SBDI-1 - inserida em 26.03.1999)".

90 "Art. $2^{\circ}$ A personalidade civil da pessoa começa do nascimento com vida; mas a lei põe a salvo, desde a concepção, os direitos do nascituro".

91 “Art. 44. São pessoas jurídicas de Direito Privado:

I - as associações;

II - as sociedades;

III - as fundações.

IV - as organizações religiosas;

V - os partidos políticos.

VI - as empresas individuais de responsabilidade limitada.

§ 1o São livres a criação, a organização, a estruturação interna e o funcionamento das organizações religiosas, sendo vedado ao poder público negar-lhes reconhecimento ou registro dos atos constitutivos e necessários ao seu funcionamento.

§ 20 As disposições concernentes às associações aplicam-se subsidiariamente às sociedades que são objeto do Livro II da Parte Especial deste Código.

§ 3o Os partidos políticos serão organizados e funcionarão conforme o disposto em lei específica”.

92 “Art. 45. Começa a existência legal das pessoas jurídicas de Direito Privado com a inscrição do ato constitutivo no respectivo registro, precedida, quando necessário, de autorização ou aprovação do Poder Executivo, averbando-se no registro todas as alterações por que passar o ato constitutivo".
} 
vinculação do patrimônio do empregador com a atividade por ele desempenhada, proporcionando garantia aos créditos dos trabalhadores.

Lado outro, a Administração Pública também pode figurar em uma relação de emprego. Como adiante se verificará, a presença do Estado em uma relação da espécie que nos propusemos a enfrentar traz algumas consequências, sendo a de maior relevo, ao menos para os fins do presente trabalho, a diretriz geral de necessidade de prévia aprovação em concurso público para a ocupação dos postos públicos, inclusive para os empregos públicos existentes em empresas estatais, o que não altera o conteúdo da relação de emprego, mas lhe impõe um acréscimo, exclusivamente, um requisito formal, qual seja, o concurso público.

Revelando posicionamento jurídico favorável à participação da Administração Pública em relações de emprego, e, além disso, seu despojamento das prerrogativas próprias da defesa do interesse público que, notadamente, as distingui das pessoas jurídicas de Direito Privado, o TST entende que a Administração Pública, ao figurar em relação de emprego, nivela-se aos particulares, em direitos e obrigações. Contudo, particularidades que envolvem a Administração Pública impedem sua cabal equiparação à generalidade dos empregadores, nomeadamente, no campo processual, haja vista as especificidades previstas no Decreto-Lei no 779, de 1969.

Toshio Mukai destaca, com amparo em Ruy Cirne Lima, que escreveu em 1952 a obra A Relação Jurídica no Direito Administrativo, que não basta a presença da Administração Pública em determinado ato ou negócio jurídico para que ocorra uma relação jurídico-administrativa, fazendo-se necessário, para tanto, que ocorra uma relação de administração dos interesses da sociedade, que se concretiza em relações com objetos que se prestem à satisfação do interesse público ${ }^{93}$. Apesar de o acesso igualitário de todos os cidadãos aos empregos públicos constituir interesse de toda a sociedade e, por essa

\footnotetext{
93 “E, após dizer que o contrato administrativo não se caracteriza pelo fato de uma das partes contratantes ser pessoa administrativa ou pelo fato de se lhe atribuir como finalidade mediata um interesse conexo com a atividade da administração estatal (pp. 65-66), assevera que o que qualifica, na verdade, como tal, o contrato administrativo, é a relação de administração, que nele se manifesta, o fim que paralisa a relação de administração; a causa finalis não poderá faltar, sem dúvida, ao contrato administrativo; há de manifestar-se, porém imediatamente pela consumação do negócio jurídico, ainda que ultima in executione, de vez que prima in intentione.

Não descarta, também, a presença, como parte, de uma pessoa administrativa no contrato, mas essa presença deve traduzir uma exigência imediata da natureza mesma da relação de administração (p. 67).

Em suma, para o Autor, "o que haverá, realmente, de administrativo, nesse contrato, qualificando-o como contrato administrativo, será tão-somente o que concernir à relação de administração". In: MUKAI, Toshio. A relação jurídico-adiministrativa. Revista Trimestral de Direito Público. n..37. 2002, p. 69.
} 
razão, receber tratamento constitucional, a presença da Administração Pública não altera o conteúdo da relação de emprego, impondo tão somente, como dito, um requisito formal, que, devido a sua relevância, pode gerar um hibridismo, isto é, o contrato de emprego entre o cidadão-trabalhador e o Estado não se regerá somente pelas leis específicas do Direito do Trabalho nem mesmo se restringirá à incidência das normas próprias do Direito Administrativo.

Logo, a publicização de uma relação jurídica não é determinada em função da natureza jurídica de seus sujeitos, pois um particular pode participar de relações próprias do Direito Eleitoral ou Processual, relações jurídicas notadamente públicas. Depreende-se, ainda, que nas situações em que a Administração Pública participa de atos ou negócios jurídicos, ela se despoja de seu poder de império e coloca-se em posição horizontal com os cidadãos $^{94}$, o que possibilita afirmar, mais uma vez, a natureza negocial do ato jurídico lato sensu que dá ocasião à relação de emprego entre cidadão/administrado e Administração Pública ${ }^{95}$.

\section{Objeto da relação de emprego.}

Em uma visão geral da relação jurídica, pode-se dizer que os bens objeto do direito podem ser representados como tudo aquilo suscetível de apropriação e com valor econômico e sobre os quais se manifestam o interesse e a vontade do titular do direito ${ }^{96}$. Por outra perspectiva, o objeto da relação jurídica é o comportamento, no sentido de um dever jurídico, imposto ao sujeito passivo para a satisfação do interesse do sujeito ativo ${ }^{97}$.

\footnotetext{
${ }^{94}$ VILANOVA, Lourival. Relação Jurídica de Direito Público. Revista dos Tribunais. ano 94, volume 37, julho de 2005. Editora Revista dos Tribunais, 2005, p. 749.

95 Maria Sylvia Zanella Di Pietro consigna que "a expressão contratos da Administração é utilizada, em sentido amplo, para abranger todos os contratos celebrados pela Administração Pública, seja sob o regime de direito público, seja sob o regime de Direito Privado. E a expressão contrato administrativo é reservada para designar tão-somente os ajustes que a Administração, nessa qualidade, celebra com pessoas físicas ou jurídicas, públicas ou privadas, para a consecução de fins públicos, segundo regime jurídico de direito público.

Costuma-se dizer que, nos contratos de Direito Privado, a Administração se nivela ao particular, caracterizando-se a relação jurídica pelo traço da horizontalidade e que, nos contratos administrativos, a Administração age como poder público, com todo o seu poder de império sobre o particular, caracterizandose a relação jurídica pelo traço da verticalidade". In: DI PIETRO, Maria Sylvia Zanella. Direito Administrativo. 17.ed. São Paulo: Atlas, 2004, p. 240.

${ }^{96}$ COSTA, Wille Duarte. Conceito e estrutura da relação jurídica. Revista da Faculdade de Direito Milton Campos. 1 v. Belo Horizonte, 1994, p. 304.

${ }^{97}$ Wille Duarte Costa afirma "dessa forma, o objeto da relação jurídica é o comportamento, no sentido de um dever jurídico, imposto ao sujeito passivo para satisfação do interesse do sujeito ativo, que não pode ser
} 
Não se devem confundir o objeto do negócio jurídico com o das obrigações que dele resultam, uma vez que a existência daquele não depende dos elementos da multiplicidade de obrigações que o compõem, de maneira que a inviabilidade ou a extinção de obrigações próprias do negócio jurídico não afetará, necessariamente, o negócio em si ${ }^{98}$. Contudo, se o ato jurídico em sentido lato for totalmente desprovido de conteúdo, ele será incapaz de provocar modificações no mundo com repercussões jurídicas.

No caso da relação de emprego, o elemento objetivo é a prestação de trabalho em favor de outrem para modificar a natureza e criar riquezas, mediante contraprestação ${ }^{99}$, nos moldes da CLT e da legislação trabalhista em geral ${ }^{100}$.

Com isso, a relação de emprego possui como objeto ${ }^{101}$ o esforço humano despendido em favor de outrem, o que já indica relevante distinção entre essa espécie de relação e a generalidade de relações próprias do Direito Civil, pautadas predominantemente na disciplina de bens.

A especificidade do objeto da relação tutelada pelo Direito do Trabalho é identificada na Constituição da Organização Internacional do Trabalho, doravante denominada OIT, especificamente no item I, a, da declaração a ela anexa, referente aos fins e objetivos, ao afirmar expressamente que o trabalho humano não é mercadoria. Mas não

superior ao direito de que é inerente, nem mesmo inferior, a não ser que a vontade do sujeito ativo possa manifestar-se no sentido de acolher a deficiência apresentada. Nesse ponto, é bom acrescentar que o objeto da relação jurídica pode ser alternativo, cabendo ao sujeito passivo escolher, entre mais de uma possibilidade de cumprimento de seu dever, como será satisfeito o interesse do sujeito ativo, se outra coisa não se estipulou. De qualquer forma, não há identidade de objetos - do direito e da relação jurídica. Do direito, o objeto é o bem, juridicamente considerado. Na relação jurídica é o dever jurídico imposto ao sujeito passivo da relação jurídica". In: COSTA, Wille Duarte. Conceito e estrutura da relação jurídica. Revista da Faculdade de Direito Milton Campos. 1 v. Belo Horizonte, 1994, p. 305.

${ }^{98}$ LORENZETTI, Ari Pedro. As nulidades o direito do trabalho. 2.ed. São Paulo: LTr, 2010, p. 32.

${ }^{99}$ Ari Pedro Lorenzetti observa que "para que se reconheça a existência de contrato de trabalho, basta que haja a intenção onerosa, na prestação laboral pactuada, ainda que presumida, não sendo necessário que as partes lhe atribuam um valor específico (CLT, art. 460). Em relação às obrigações do trabalhador, da mesma forma, não é necessário, que as partes desçam a detalhes, suprindo-se sua omissão com os dispositivos legais aplicáveis à espécie (CLT, art. 456, parágrafo único). Ibidem, p. 32.

${ }^{100}$ LORENZETTI, loc. cit.

${ }^{101}$ Manuel A. Domingues Andrade refere-se ai objeto da relação jurídica nos seguintes termos: "objeto da relação jurídica é aquilo sobre que incide o direito subjetivo; sobre que incidem o poder ou poderes em que este direito se analisa. Não é, pois, o próprio direito subjetivo e o correspondente dever jurídico: estes formam o conteúdo da relação jurídica. Não são tão-pouco os poderes que o direito subjetivo comporta: estes são o conteúdo desse direito. O objeto da relação jurídica define-se, portanto, focando nela somente o lado activo. Reconduz-se afinal ao objeto do correspondente direito subjetivo. Objeto de relações jurídicas será pois, em última análise, a mesma coisa que objeto de direitos. As mais diversas realidades podem desempenhar este papel. Assim, uma pessoa, uma coisa, um produto intelectual (obra de engenho humano), são modalidades indiscutíveis ou pouco discutíveis". In: ANDRADE. Manuel A. Domingues. Teoria Geral da Relação Jurídica. Vol I: sujeito e objeto. Coimbra: Livraria Almedina, 2003, p. 20 e 21. 
se esgota nesse ponto, outra grande distinção está na impossibilidade de apropriação do trabalho humano ${ }^{102}$, pois o que se adquire é apenas o resultado material do trabalho. Historicamente, figuras como a escravidão e até mesmo vassalagem identificavam o próprio trabalho, ou mesmo o trabalhador, como objeto da relação jurídica, e não como sujeito $^{103}$.

Nessa linha de raciocínio, o objeto da relação de emprego é o esforço humano, seja braçal, seja intelectual, seja misto, e, de certo modo, o resultado que ele produz, revelando-se inapropriada a identificação, de qualquer modo, do trabalhador com o objeto, uma vez que se cuida de sujeito da relação jurídica, ao menos na atual estrutura jurídica e econômica.

Acontece que os efeitos da relação jurídica dependem da idoneidade de seu objeto, que não pode ser qualificado como ilícito pelo ordenamento jurídico, assim como ocorre com o jogo do bicho, cuja produção de efeitos trabalhistas é amplamente rechaçada pela jurisprudência ${ }^{104}$, corroborando a impossibilidade de um fato não poder ser tido como ilícito e, simultaneamente, produzir efeitos lícitos na seara trabalhista.

Em contraponto, Homero Batista Mateus da Silva ${ }^{105}$ chama a atenção para a existência de entendimento doutrinário e jurisprudencial que acolhe a necessidade de concessão de direitos trabalhistas aos envolvidos em conduta ilícita com a finalidade de que a situação de desamparo de trabalhadores nessas circunstâncias não sirva de estímulo à organização criminosa ou contraventora na reiteração de condutas. O fundamento teórico

102 “A pessoa, em sentido jurídico, não poder ser objeto do direito, muito menos da relação jurídica. Quanto ao pátrio poder, a confusão tem consistido em se tomar a sanção, consubstanciada em castigos corporais, infligidos ao filho, como elemento da relação jurídica. Em verdade, o que o direito assegura ao pai é o poder exigir do filho um determinado comportamento que, não atendido, pode ser estimulado ou imposto sob sanção, identificada no exemplo dado pelo castigo corporal. A sanção é elemento exterior e não é componente da relação jurídica. Seu fim é fazer com que o pai seja atendido, nos limites de sua vontade e de acordo com o direito a ele assegurado. Dessa forma, o objeto não é e nem pode ser o filho, já que sendo pessoa, humana, natural, não pode ser objeto de direito, nem de relação jurídica”. In: COSTA, Wille Duarte. Conceito e estrutura da relação jurídica. Revista da Faculdade de Direito Milton Campos. 1 v. Belo Horizonte, 1994, p. 307.

${ }^{103}$ Não se olvida que atualmente encontramos situações muito próximas da histórica figura da escravidão, todavia, é sensível a distinção, uma vez períodos não muito remotos, a própria ordem jurídica reconhece a figura em relevo, considerando o trabalhador reles objeto de ralação jurídica; já nos tempos atuais, não se tem conhecimento de ordenamento jurídico que considerem o trabalhador como objeto, muito embora se encontrem, com espantosa facilidade, trabalhadores em condições análogas a de escravo.

104 “OJ-SDI1-199 JOGO DO BICHO. CONTRATO DE TRABALHO. NULIDADE. OBJETO ILÍCITO (título alterado e inserido dispositivo) - DEJT divulgado em 16, 17 e 18.11.2010. É nulo o contrato de trabalho celebrado para o desempenho de atividade inerente à prática do jogo do bicho, ante a ilicitude de seu objeto, o que subtrai o requisito de validade para a formação do ato jurídico".

${ }^{105}$ SILVA, Homero Batista Mateus da. Curso de direito do trabalho aplicado, vol.6: Contrato de Trabalho. Rio de Janeiro: Elsevier, 2009, p. 12. 
dessa linha de entendimento repousa na separação entre atividade fim e atividade meio no âmbito dos crimes e das contravenções penais, opção argumentativa que permitiria, por exemplo, proteger o manobrista, o porteiro e o faxineiro da casa de jogos de azar, mas não permitiria a concessão da tutela do Direito do Trabalho ao fabricante de armas e de entorpecentes $^{106}$. É o próprio Homero Batista Mateus da Silva quem indica os inconvenientes da pretendida distinção, porquanto para o doutrinador em relevo carece de suficiente previsão em lei o conceito de atividade fim e de atividade meio, há excessivo pragmatismo na distinção entre as atividades em destaque e, por fim, a peculiaridade de não se alterar por interpretação o caráter ilícito do objeto do negócio jurídico ${ }^{107}$. Nessa linha, a despeito da ampliação da tutela trabalhista sugerida pelo entendimento alternativo ao posicionamento prevalente, entendemos que a licitude do objeto é imprescindível à incidência do Direito do Trabalho.

Desta feita, o trabalho humano é o objeto do contrato de emprego, todavia, a plenitude de seus efeitos depende, necessariamente, de que ele não seja considerado ilícito pelo ordenamento jurídico. Não se deve, porém, confundir a ilicitude do objeto da relação de emprego com a violação de outras normas, que impõem restrições relacionadas, por exemplo, com a idade mínima para o trabalho, que é considerado, por doutrina e jurisprudência, como trabalho proibido ${ }^{108}$.

\section{Subordinação.}

A subordinação, como dito, é o elemento categorial que permite distinguir a relação de emprego de outras relações próximas a ela. É bem verdade que a subordinação comporta alguns graus de submissão entre os sujeitos da relação negocial, não só a trabalhista, mas, também, em relações que digam respeito ao trabalho autônomo. Encontra-

\footnotetext{
${ }^{106}$ SILVA, Homero Batista Mateus da. Curso de direito do trabalho aplicado, vol.6: Contrato de Trabalho. Rio de Janeiro: Elsevier, 2009, p. 12.

${ }^{107}$ Ibidem, p. 14.

${ }^{108}$ Alice Monteiro de Barros, com amparo nas lições de Emilio Berri, faz a distinção entre trabalho ilícito e trabalho proibido no seguintes termos: "cumpre lembrar que a atividade ilícita não se confunde com a atividade proibida. Na primeira hipótese, o contrato não produz nenhum efeito, pois o "negócio é reprovado pelo direito, em defesa dos interesses da sociedade, ou dos bons costumes e dos valores existentes". Nesse caso, o "valor tutelado é a realização da ordem pública". Na segunda hipótese, isto é, na atividade proibida, o contrato produz certos efeitos e "a tutela da ordem pública se realiza de modo mediato, prevalecendo o interesse do trabalhador". A título de exemplo, o trabalho realizado pelo menor de 14 anos é proibido, portanto, o ajuste com ele firmado é nulo, mas produz certos efeitos, pois autoriza o pagamento de uma compensação razoável, que poderá até mesmo ser a retribuição pactuada, se se entender que é justa”. In: BARROS, Alice Monteiro. Curso de direito do trabalho. 7. ed. São Paulo: LTr, 2011, p. 194.
} 
se a subordinação em grau máximo nas relações de emprego e, em grau reduzido, nas relações de trabalho autônomo ${ }^{109}$, em que o prestador dos serviços também deve atender a certas exigências estabelecidas pelo tomador.

A propósito, é comum a utilização do neologismo parassubordinação para se referir ao trabalho prestado com menor grau de subordinação, tema que empolgou o estudo $^{110}$ dos trabalhadores situados em uma zona intermediária entre autônomos e empregados, assunto que não será aprofundado em razão dos limites deste trabalho.

O termo subordinação possui, ao menos, três abordagens distintas a respeito de seu significado, o econômico, o técnico e, finalmente, o jurídico. Os dois primeiros tendem a ser abandonados, uma vez que pertencem a realidade já superada ${ }^{111}$. Já o significado mais aceito, o jurídico, representa o conjunto de ordens emitidas pelo empregador, quanto à organização e aos métodos a serem desenvolvidos no ambiente de trabalho, que devem ser observadas pelo trabalhador (empregado), mas que devem respeitar, necessariamente, os padrões civilizatórios e de dignidade ${ }^{112}$.

Como desfecho, fala-se, também, em dimensões clássica ou subjetiva, objetiva e estrutural da subordinação. Diz-se clássica a dimensão que avista a subordinação como compromisso assumido pelo trabalhador de acolher o poder de direção empresarial no que se refere ao modo de realização de sua prestação de trabalho ${ }^{113}$. Seguidamente, afirma-se a dimensão objetiva que enquadra a incidência da subordinação sobre as atividades exercidas

109 SILVA, Homero Batista Mateus da. Curso de direito do trabalho aplicado, vol.1: Parte Geral. Rio de Janeiro: Elsevier, 2009, p. 29.

${ }^{110}$ SILVA, Otavio Pinto e. Subordinação, autonomia e parassubordinação nas relações de trabalho. LTr, 2004.

${ }^{111}$ Homero Batista Mateus da Silva ensina sobre o significado econômico da subordinação "se entendia que o contrato era formado por um empregado desprovido de bens materiais, de um lado, e por um empregador, afortunado e enriquecido pela atividade empresaria, de outro lado. Essa dicotomia lança sementes inclusive para uma luta de classes e para uma separação dissociada da realidade entre os que se servem da relação de emprego para a retirada de alimentos de subsistência e aqueles que dela se servem para um enriquecimento imoral às custas da energia humana alheia. Olvidava-se essa premissa de que o empobrecimento do trabalhador e o enriquecimento do empregador constitui apenas uma presunção e, ainda assim, relativa, havendo diversas dúvidas em torno de sua base científica". Sobre o aspecto técnico, assevera que "acreditase, por este estudo, que o empregador opta por determinada linha de produção porque domina aquele ciclo da economia e o maquinário ou os procedimentos nele envolvidos. Poderá, assim, passar aos empregados os comandos necessários ao desenvolvimento da profissão e ditar a forma pela qual pretende ver elaborados os produtos e serviços" (...) "é relativamente presumível que o empregador detenha maiores conhecimentos sobre o campo em torno do qual milita, assim como se presume igulamente de forma relativa que o empregador conhece melhor o mercado consumidor e a concorrência que o cerca, respeitando-se de forma absoluta suas diretrizes".In SILVA, op. cit., pp. 23-24 e 25-26.

112 SILVA, op. cit., p. 28.

${ }^{113}$ DELGADO. Maurício Godinho. Curso de direito do trabalho. 12. ed. São Paulo: LTr, 2013, p. 295. 
pelo emprego e, segundo ensinamentos de Paulo Emílio Ribeiro de Vilhena, representa a participação integrativa da atividade do trabalhador na atividade do credor do trabalho ${ }^{114}$. Há, ainda, a dimensão estrutural, mais recente do que as outras dimensões mencionadas, de acordo com a qual a subordinação se expressa pela inserção do trabalhador na dinâmica do tomador de seus serviços, independentemente de receber, ou não, suas ordens diretas, o relevante, nessa dimensão, é a introdução do trabalhador na dinâmica de organização e funcionamento do tomador, mesmo que ele não se identifique como o seu empregador formal $^{115}$. Veja-se que a dimensão estrutural é a única que permite o estabelecimento de relações entre o trabalhador e o tomador de serviços em terceirizações ilícitas - figura rechaçada pelo TST por meio de sua Súmula n. ${ }^{\circ} 331$, nomeadamente naquelas ocorridas em atividade-fim com a existência de intermediador ou preposto da empresa prestadora de serviço, o que, aplicássemos as outras dimensões da subordinação, afastaria o reconhecimento de relação de emprego com o tomador de serviço. $\mathrm{O}$ até aqui exposto a respeito da subordinação foi suficiente para destacar sua relevância para o Direito do Trabalho e para a manutenção da resistência dessa seara do Direito às investidas de novas estratégias econômicas abusivas, caso da terceirização em atividade-fim.

\section{Posição no tempo, no espaço, causa e vontade.}

Aos elementos que integram o título acima são ofertados menores esforços, em razão do caráter secundário que ocupam nesta pesquisa, muito embora sejam elementos gerais dos atos jurídicos e, desse modo, de extrema importância para o Direito.

Professa Antônio Junqueira de Azevedo que todo negócio jurídico ocorre em determinado momento e em determinado local ${ }^{116}$, desse modo, tempo e espaço são elementos do contrato do emprego. Em razão dos problemas enfrentados no presente trabalho, o local do contrato de emprego é o território brasileiro, muito embora ocorra com grande frequência a contratação de trabalhadores pelas Estatais para que atuem no exterior, e o tempo, refere-se especialmente às contratações ocorridas a partir de 05 de outubro de

\footnotetext{
${ }^{114}$ VILHENA, Paulo Emílio Ribeiro de. Relação de emprego: estrutura legal e supostos. 2. ed. ver., atual. e aum, São Paulo: LTr, 1999. p. 478.

${ }^{115}$ DELGADO. Maurício Godinho. Curso de direito do trabalho. 12. ed. São Paulo: LTr, 2013. p. 296.

116 AZEVEDO, Antônio Junqueira de. Negócio jurídico: existência, validade e eficácia. 4. ed. atual. de acordo com o novo Código Civil (Lei n. 10.406, de 10-1-2002). São Paulo: Saraiva, 2002, p. 33.
} 
1988. Veja-se que os elementos tempo e espaço acabam por indicar as normas aplicáveis ao negócio jurídico.

A causa está presente em todo negócio jurídico, pois este sempre está atrelado a uma finalidade ou a uma função prática ${ }^{117}$. Com isso, também se verificam nos vínculos jurídicos estabelecidos sob os preceitos do Direito do Trabalho, pois se verificam com facilidade o desejo de o empregador contar com a mão de obra alheia e a vontade de o trabalhador receber contraprestação por sua energia, além, é claro, de outras motivações que possam empolgar a própria celebração do contrato ${ }^{118}$. Cumpre observar, ainda, que é a irregularidade da causa que mais exige a atenção do Direito, tendo em vista que, na generalidade dos casos, ela cumpre seu papel sem ser percebida ${ }^{119}$.

Por último, a relevância e os contornos da vontade já foram destacados por ocasião da distinção entre relação e contrato de emprego e, devido a sua posição arrabalde no presente estudo, são desnecessários maiores aprofundamentos.

\section{Forma na relação de emprego.}

Diante do estudo realizado a respeito dos elementos e dos pressupostos do contrato de emprego, pode-se avançar a ponto de se afirmar que, ao escolher um tipo de negócio jurídico, os sujeitos devem se submeter ao conjunto de normas jurídicas para ele estabelecidas. Devem, desse modo, ser observados os elementos e pressupostos, a fim de que os atos jurídicos sejam, inicialmente, existentes e, em seguida, válidos.

É curioso notar que a forma, redutível ao meio pelo qual o sujeito expressa sua vontade, poderá ser oral, escrita, mímica, consistir no próprio silêncio, ou, ainda, em atos dos quais se deduz a declaração de vontade. Como consequência, não há ato ou negócio jurídico sem forma ${ }^{120}$. A existência de atos jurídicos com forma livre ou, em outras palavras, sem forma prescrita em lei é questão que diz respeito ao plano da validade. Logo, como ensina Antônio Junqueira de Azevedo, deve-se afastar a confusão primária de

\footnotetext{
${ }^{117}$ LORENZETTI, Ari Pedro. As nulidades no direito do trabalho. 2.ed. São Paulo: LTr, 2010, p. 37.

${ }^{118}$ GOMES, Orlando. GOTTSCHALK, Elson. Curso de direito do trabalho. Rio de Janeiro: Forense, 2006, pp. 169-170.

${ }^{119}$ LORENZETTI, op. cit., p. 37.

${ }^{120}$ GUALAZZI, Eduardo Lobo Botelho. Ato administrativo inexistente. São Paulo: Revista dos Tribunais, 1980, p. 128 .
} 
entender que apenas os atos jurídicos com forma determinada em lei é que têm forma, sem se dar conta de que todos os atos a têm, ainda que livre, sob pena de inexistirem ${ }^{121}$.

No Direito do Trabalho, como diretriz geral, não há a exigência de observância de determinada forma, vale dizer, impera a liberdade de forma, conclusão que se extrai da redação do caput do art. 442 da CLT, ao explicitar que o contrato é o acordo tácito ou expresso. Todavia, em algumas hipóteses mais complexas, o legislador estabeleceu a necessidade da forma escrita, como ocorre nos casos do atleta profissional (art. $3^{\circ}$, parágrafo único, I, da Lei $n^{\circ}$ 9.615/1998), do artista (art. 9º ${ }^{\circ}$ caput, da Lei $\mathrm{n}^{\circ}$ 6.533/1978), do radialista (art. $8^{\circ}$, caput, da Lei $\mathrm{n}^{\circ}$ 6.615/1978). No mesmo sentido, também é exigida a forma escrita pelo legislador para as hipóteses em que se destina maior grau de proteção, como o aprendiz (art. 428 da CLT), o contrato temporário (art. $9^{\circ}$, caput, da Lei $\mathrm{n}^{\circ}$ $6.019 / 1974$ ), o contrato de pequeno prazo na zona rural (art. 14-A, $\S 3^{\circ}$, II, da Lei $n^{\circ}$ $5.889 / 1973)^{122}$.

Observe-se que a forma não só representa a exteriorização de vontade, mas, também, em uma concepção mais ampla, todas as formalidades que devem ser observadas durante o processo de formação de vontade ${ }^{123}$. Com isso, o conjunto de preparos necessários à manifestação da vontade também diz respeito à forma. Nesse sentido, encontramos a exigência do concurso público para a válida formação de relação de emprego com a Administração Pública, que está contida no art. 37, II e $\S 2^{\circ}$, da CR, exemplo de solenidade no Direito do Trabalho e de procedimento direcionado à revelação da vontade. Confira-se:

\footnotetext{
"Art. 37. A Administração pública direta, indireta ou fundacional, de qualquer dos Poderes da União, dos Estados, do Distrito Federal e dos Municípios obedecerá aos princípios de legalidade, impessoalidade, moralidade, publicidade e, também, ao seguinte: (...)

II - a investidura em cargo ou emprego público depende de aprovação prévia em concurso público de provas ou de provas e títulos, ressalvadas as nomeações para cargo em comissão declarado em lei de livre nomeação e exoneração.
}

(..)

\footnotetext{
${ }^{121}$ AZEVEDO, Antônio Junqueira de. Negócio jurídico: existência, validade e eficácia. 4. ed. atual. de acordo com o novo Código Civil (Lei n. 10.406, de 10-1-2002). São Paulo: Saraiva, 2002, p. 126.

${ }^{122}$ SILVA, Homero Batista Mateus da.Curso de direito do trabalho aplicado, vol. 6:contrato de trabalho. Rio de Janeiro: Elsevier, 2009, p.23.

${ }^{123}$ DI PIETRO, Maria Sylvia Zanella. Direito Administrativo. 17.ed. São Paulo: Atlas, 2004, p. 200.
} 
$\S 2^{\circ}$. A não-observância do disposto nos incisos II e III implicará a nulidade do ato e a punição da autoridade responsável, nos termos da lei”.

Assim, no Direito do Trabalho, mais do que em qualquer outro ramo, impera a liberdade de forma. Nos demais casos em que a legislação trabalhista estabelece exigências formais, em geral, a finalidade é apenas probatória, o que indica que a constituição da relação de emprego e sua validade foram tratadas com muita simplicidade pela CLT $^{124}$. Nos campos do Direito Administrativo, ao menos no âmbito federal, depreende-se a informalidade dos atos administrativos do art. 22, caput, da Lei $\mathrm{n}^{\circ}$ 9.784/1999, de seguinte conteúdo: "os atos do processo administrativo não dependem de forma determinada senão quando a lei expressamente a exigir".

Não obstante, a CR estabelece uma formalidade para a constituição válida da relação de emprego com a Administração Pública, qual seja, a prévia aprovação em concurso público, sob pena de ser considerada nula. Em outras palavras, nessa hipótese, a forma é requisito de validade.

Consequentemente, a forma pode se prestar à constituição de prova ou dizer respeito à própria substância do ato ou negócio, o que dá ensejo à distinção entre forma como pressuposto de validade - ad substantiam ou ad solimmenitatem - e a forma como prova do ato - ad probationem. Diante desses termos, estabelecida a solenidade por norma jurídica, como no caso do concurso público para a relação de emprego público, que constitui autêntico procedimento, sua inobservância implicará nulidade do negócio jurídico $^{125}$.

Adicionalmente, Seabra Fagundes relata que a invalidade do negócio jurídico em razão de preterição de solenidade ocorrerá em duas hipóteses, quais sejam, quando a lei expressamente exigir a forma preterida ou se a forma for instituída com finalidade que só possa ser atendida pela sua obediência ${ }^{126}$. Veja-se que a exigência do concurso público diz respeito à validade do negócio jurídico, de modo que é forma ad substantiam ou ad solimmenitatem, não ocupando o papel de singela prova do ato negocial celebrado.

Nesse prisma, o concurso público pode ser compreendido como uma relação jurídico-administrativa entre todos os candidatos e a Administração Pública, porquanto o

\footnotetext{
${ }^{124}$ LORENZETTI, Ari Pedro. As nulidades o direito do trabalho. 2.ed. São Paulo: LTr, 2010, p. 213.

${ }^{125}$ DI PIETRO, Maria Sylvia Zanella. Direito Administrativo. 17.ed. São Paulo: Atlas, 2004, p. 201.

${ }^{126}$ FAGUNDES, Seabra M. O Controle dos Atos Administrativos pelo Poder Judiciário. 4.ed. Rio de Janeiro: Forense, p. 81.
} 
aspecto procedimental do concurso presta-se a garantir o acesso igualitário aos cargos e empregos públicos, bem como a realização da eficiência administrativa com a escolha dos mais aptos conforme o que revelarem as provas do concurso. Por outro lado, não se deve confundir a relação necessária ao ingresso nas estruturas da Administração Pública com as relações que se estabelecerão com o início dos trabalhos em favor da estrutura estatal ${ }^{127}$.

Logo, o concurso público se enquadra como pressuposto de validade que, muito embora goze de grande prestígio contemporaneamente, nem sempre se fez necessário para a validade dos atos jurídicos de repercussão trabalhista celebrados com a Administração Pública, como indica o histórico constitucional brasileiro.

127 “Além das relações que se verificam no interior de um órgão complexo, e das relações de órgão para órgão, temos a destacar as relações entre titular-de-órgão e órgão. Sempre claro e incisivo, Ugo Rocco observa que entre juiz e cargo (órgão) há relações administrativas (seleção, nomeação, posse, deveres e direitos funcionais da qualificação de membro do poder judiciário), que não se confundem com as funções de órgão judicante. Algumas normas estão, possivelmente, na Constituição, outras, em lei ordinária, outras, ainda, em Regimento Interno do órgão colegial supremo (Tribunal): normas que definem relações jurídicoadministrativas, que não se confundem com as normas-de-organização, ou normas instituintes do órgão, como porção constitucional de competência”. In: VILANOVA, Lourival. Relação Jurídica de Direito Público. Revista dos Tribunais. ano 94, volume 37, julho de 2005. Editora Revista dos Tribunais, 2005 , p. 764. 


\section{CONCURSO PÚBLICO: PRESSUPOSTO FORMAL DA RELAÇÃO DE EMPREGO COM A ADMINISTRAÇÃO PÚBLICA.}

A ampla acessibilidade das pessoas aos postos de trabalho públicos por meio de concurso público possui duplo aspecto: possibilita que os mais capacitados profissionalmente tenham acesso à estrutura pública, o que atende aos interesses dos indivíduos e aos da própria Administração, e, por outro lado, permite que todos, independentemente de injunções subalternas, possam ingressar no serviço público ${ }^{128}$.

Em um país de profundas desigualdades econômicas, sociais e culturais, o certame baseado na meritocracia ainda não é a forma ideal, mas se mostra, ao menos por ora, o procedimento mais democrático de seleção dos ocupantes das vagas oferecidas pela Administração.

De todo modo, a vinculação do acesso aos postos públicos às aptidões e competências dos candidatos, e somente a elas, consiste em medida estabelecida pelo Poder Constituinte para garantir, a um só tempo, a observância de princípios consagrados na CR, tais como igualdade, moralidade, impessoalidade e eficiência, de modo que, não sendo observada, impõem-se a declaração de nulidade da contratação e a responsabilização do administrador público.

Em uma visão geral, os sujeitos podem se vincular ao Estado de diversas maneiras, consoante as peculiaridades da vinculação. O gênero de suas designações recebe o nome de agente público e se desdobra em diversas espécies. O termo agente público é amplíssimo, porquanto abrange quem quer que desempenhe funções estatais, por exemplo, o chefe do Poder Executivo, os senadores, os ocupantes de cargos ou empregos públicos da Administração Direta e Indireta e até mesmo pessoas ligadas ao aparelhamento estatal a título precário (concessionários, permissionários, delegados de função ou ofício público etc) ${ }^{129}$.

Entre as espécies de agentes públicos, interessa-nos os servidores públicos em sentido amplo, identificados por Maria Sylvia Zanella Di Pietro como as pessoas físicas que prestam serviços ao Estado e à Administração Indireta com vínculo estatutário ou

\footnotetext{
${ }^{128}$ REIS, Carlos David Santos Aarão. O princípio da igualdade nos concursos públicos. Revista de Ciência Política. Rio de Janeiro. v.32. n.3. p.31-41. maio/jul. 1989, p. 36-37.

${ }^{129}$ MELLO, Celso Antônio Bandeira de. Curso de Direito Administrativo. 22.ed. São Paulo: Malheiros, 2007, p. 235-236.
} 
empregatício e com pagamentos realizados pelos cofres públicos ${ }^{130}$. A espécie de agentes públicos em evidência comporta subdivisão em: servidores estatutários, que são aqueles sujeitos a regime estatutário e ocupantes de cargos públicos; empregados públicos, contratados sob o regime da legislação trabalhista e ocupantes de emprego público; e servidores temporários, que são contratados por tempo determinado, para o atendimento de necessidade temporária de excepcional interesse público, exercendo função sem vinculação efetiva a cargo ou emprego público ${ }^{131}$.

Percebe-se, assim, que a vinculação permanente ou não transitória de cidadãos com a Administração para os fins de prestação de trabalho pode ser, basicamente, de duas espécies, contratual e estatuária, distinção que também é encontrada em outros países, como na Espanha ${ }^{132}$.

No caso da CR vigente, inicialmente o regime era único para a Administração Direta e Indireta que possuísse a natureza de pessoa jurídica de Direito Público, com direitos e obrigações fixados em lei, vale dizer, por estatuto. Essa vinculação à lei decorre da necessidade de observância do princípio da legalidade estabelecido no art. 37, caput, da CR, o que acaba for afastar o regime negocial das relações de trabalho com Administração Pública, porquanto impossível a via da transação na fixação de direitos e obrigações, de maneira que a vontade do trabalhador é indiferente quanto a esses pontos, muito embora seja relevante para a formação da relação jurídica.

\footnotetext{
${ }^{130}$ DI PIETRO, Maria Sylvia Zanella. Direito Administrativo. 17.ed. São Paulo: Atlas, 2004, p. 433.

${ }^{131}$ Ibidem, p 434.

${ }^{132}$ Segundo Fco. Javier Izquierdo Hernandez e Monica Molina Garcia "las relaciones de trabajo en las Administraciones Públicas son de dos classes, sometidas a dos regímenes jurídicos distintos. Con la expresión "empleo público", admitida legalmente, se quiere hacer referencia a este fenômeno diversificado del empleo em el seno de la Administración Pública. En efecto, el empleo, em la parte del sector público constituída por la Administración Pública, se encuentra dividido em dos clases o sectores, uno de carácter contractual, sometido a las reglas jurídicas del Derecho del Trabajo, que cuando se aplica en el seno de las Administraciones Públicas "adquiere rasgos singulares, pero desde luego no irreconocibles respecto al genérico de los trabajadores por cuenta ajena", y outro diferenciado, que es el empleo público estatutáriofuncionarial ("Función Pública", en um sentido tradicional y estricto), sometido al Derecho Administrativo. Este régimen dualista del empleo público adquiró carta de naturaleza em el Texto Articulado de la Ley de Funcionarios Civiles del Estado de 7 de febrero de 1964 (artículo 7) y continuó com la Ley 30/1984, de 2 de agosto, de Medidas para la Reforma de la Función Pública, que inauguro la regulación, em un mismo texto normativo, de las formas de prestar trabajo em la Administración, la funcionarial y la laboral. Esta dualidad del empleo público no solo está admitida para el personal que presta sus servicios en la Administración del Estado y sus Organismos Autónomos, sino también para el resto de Administraciones Públicas de base territorial, Comunidades Autônomas y Coporaciones Locales. En el seno de cada Administración Pública, la delimitación entre ambos tipos de empleo, el trazo de la línea divisória que los separa, se levva a efecto normativamente mediante el establecimento de criterios legales con arreglo a los cuales há de decidirse qué puestos de trabajo se asignan al sector funcionarial y cuáles al laboral" In: HERNANDEZ, Fco. Javier Izquierdo e Monica Molina Garcia. La laboralización de los funcionarios públicos. Valencia: Tirant lo blanch, 1996, pp. 13-16.
} 
Com o advento da Emenda Constitucional 19/98, conhecida como emenda da reforma administrativa do estado, aboliu-se o regime jurídico único, o que possibilitou a coexistência de regime estatutário e de negocial (CLT) ${ }^{133}$. Contudo, por questões formais o STF deferiu medida cautelar em que suspendeu a eficácia do art. 39, caput, da CR, com a redação dada pela emenda mencionada, o que implicou, justamente, o retorno da unicidade de regime jurídico ${ }^{134}$. Em nosso entender, até a decisão meritória da ADI 2.135 pelo STF, o regime jurídico que venha a ser estabelecido deve ser estatutário, em que, repita-se, os direitos e obrigações são exclusivamente estabelecidos por lei.

Veja-se que por ocasião do julgamento acima, entendeu o STF que a Emenda Constitucional $\mathrm{n}^{\circ}$ 19/1998 não foi aprovada pela maioria qualificada necessária à modificação do Texto Maior, pois o respectivo projeto obteve somente duzentos e noventa e oito votos, e não os trezentos e oito necessários na Câmara dos Deputados. A medida cautelar deferida ampara-se em vício formal de constitucionalidade, ou seja, na inobservância dos procedimentos ou competências fincados na Constituição, de maneira que não fora afastada pelo STF, ao menos nessa assentada, a compatibilidade do conteúdo da modificação com as normas que consagram as cláusulas pétreas ${ }^{135}$.

Admitindo-se que o regime jurídico varia de acordo com a opção realizada pelas entidades que integram a Federação, por se inserir a escolha na autonomia política, administrativa e financeira dos Municípios, dos Estados, do Distrito Federal e da União ${ }^{136}$, seria válida a opção por um regime negocial mesmo para as pessoas jurídicas de Direito Público. Contrariamente, há entendimentos doutrinários que identificam o regime jurídico único com o regime estatutário, ao argumento de que ele proporciona maiores vantagens à

\footnotetext{
133 BARROS, Monteiro de Barros. Contrato de emprego do servidor público antinomias. in O Servidor público e a Justiça do Trabalho: homenagem ao Ministro Ronaldo José Lopes Leal. José Ronald Cavalcante Soares, coordenador. São Paulo: LTr, 2005, p. 20.

134 BRASIL. Supremo Tribunal Federal. Acórdão em Medida Cautelar em Ação Direta de Inconstitucionalidade n. 2.135-4/DF. Relator: GRACIE, Ellen. Publicado no DJ de 07.03.2008. Disponível em: <http://redir.stf.jus.br/paginadorpub/paginador.jsp?docTP=AC\&docID=513625>. Acessado em 30.05.2013.

135 “Constituição da República. Art. $60, \S 4^{\circ}$ Não será objeto de deliberação a proposta de emenda tendente a abolir: I - a forma federativa de Estado; II - o voto direto, secreto, universal e periódico; III - a separação dos Poderes; IV - os direitos e garantias individuais".

136 “Constituição da República. Art. 18. A organização político-administrativa da República Federativa do Brasil compreende a União, os Estados, o Distrito Federal e os Municípios, todos autônomos, nos termos desta constituição".
} 
Administração e aos administrados ${ }^{137}$. Adicionalmente, a autonomia dos entes encontra limites no próprio texto constitucional, que estipula o regime jurídico a ser observado em algumas carreiras, por exemplo, a Magistratura (arts. 93 a 95) e o Ministério Público (arts. 127 e 128), além de impor a observância à legalidade em por toda a Administração Pública (art. 37, caput).

Esclareça-se, no que se refere às pessoas jurídicas de Direito Privado, empresas públicas e sociedades de economia mista, que o regime de vinculação entre Administração Pública e servidores sempre foi o negocial, sem a restrição de somente se estabelecerem direitos e obrigações por meio de lei, consoante art. 173, §1 $1^{\circ}$, II, da CR, em todas as suas redações.

Pois bem, ultrapassada a distinção sobre as diversas espécies de vinculações com a Administração Pública cumpre verificar, ainda, a qual órgão do Poder Judiciário foi atribuída competência para processar e julgar os litígios entre a estrutura estatal e os servidores em sentido amplo a ela vinculada. O enfrentamento dessa questão passa pela análise de textos constitucionais, da legislação ordinária, da Convenção 151 da OIT e da jurisprudência do STF, a base da pesquisa não se estabelece sem propósito, é fixada em razão de a competência dos órgãos do Judiciário possuir preponderantemente assento na Constituição e, também, na peculiaridade de que cabe ao Pretório Excelso a última decisão acerca de questões constitucionais.

Ao menos a partir do julgamento do Recurso Extraordinário $90.391^{138}$, ocorrido em 22.08.1979, o STF fixou o entendimento de que os servidores públicos regidos por legislação diversa da trabalhista tem seus litígios processados e julgados pela Justiça Comum. O texto constitucional vigente à época do litígio, o de 1969, estabelecia que os ocupantes de cargos seguiriam as determinações fixadas em lei (art. 97, caput) ${ }^{139}$ e que os servidores admitidos em caráter temporário ou para as funções de natureza técnica e

\footnotetext{
${ }^{137}$ MARTINS, Gilberto Augusto Leitão. Admissão e dispensa de empregado publico - efeitos da contratação com inobservância ao princípio do concurso publico. LTr: legislação do trabalho. suplemento trabalhista. Sao Paulo. v.29. n.73. p.489-91. 1993, p. 490.

138 BRASIL. Supremo Tribunal Federal. Acórdão no Recurso Extraordinário n. 90.391. Relator: ALVES, Moreira. Disponível em: $<$ http://redir.stf.jus.br/paginadorpub/paginador.jsp?docTP=AC\&docID=184047>. Acessado em 30.05.2013. 139 "Art. 97. Os cargos públicos serão acessíveis a todos os brasileiros que preencham os requisitos estabelecidos em lei".
} 
especializada tinham o regime jurídico estabelecido em lei especial (art. 106) ${ }^{140}$. Na Constituição de 1967, em que pese a submissão dos ocupantes de cargos ao regime estatutário, os servidores admitidos temporariamente para obras ou contratados para funções de natureza técnica ou especializada eram regidos pela legislação trabalhista ${ }^{141}$.

Veja-se que as Constituições de $1967^{142}$ e $1969^{143}$ atribuíam à Justiça do Trabalho a competência para processar e julgar apenas os litígios entre empregados e empregadores, com exceção dos litígios oriundos de acidentes de trabalho. Com a Constituição de $1988^{144}$ substitui-se o termo empregado pela palavra trabalhador, o que em nada alterou o entendimento do STF sobre a matéria, por relevante, destacamos os dizeres do Ministro Octavio Gallotti, relator do Conflito de Jurisdição 6.829-8:

"É certo que o disposto no art. 114 da nova Constituição traduz ampliação da competência da Justiça do Trabalho, em comparação com o teor do antigo 142. Isto ocorre, por exemplo, com a generalização da competência para o julgamento dos litígios oriundos do cumprimento das sentenças coletivas (art. 114, citado, parte final).

Mas, no tocante ao ponto que interessa a solução da espécie dos autos e vem destacado no parecer, isto é, à enumeração dos entes sujeitos à competência da Justiça especializada, a novidade do art. 114, em vigor, resume-se à inclusão dos dissídios com pessoas de Direito Públicos externo e com a União Federal, antes submetidos à Justiça Federal.

140 “Art. 106. O regime jurídico dos servidores admitidos em serviços de caráter temporário ou contratados para funções de natureza técnica especializada será estabelecido em lei especial".

141 “Art 104 - Aplica-se a legislação trabalhista aos servidores admitidos temporariamente para obras, ou contratados para funções de natureza técnica ou especializada".

142 “Art 134 - Compete à Justiça do Trabalho conciliar e julgar os dissídios individuais e coletivos entre empregados e empregadores e as demais controvérsias oriundas de relações de trabalho regidas por lei especial.

(...)

$\S 2^{\circ}$ - Os dissídios relativos a acidentes do trabalho são da competência da Justiça ordinária”.

143 “Art. 142. Compete à Justiça do Trabalho conciliar e julgar os dissídios individuais e coletivos entre empregados e empregadores e, mediante lei, outras controvérsias oriundas de relação de trabalho.

(...)

$\S 2^{\circ}$ Os litígios relativos a acidentes do trabalho são da competência da justiça ordinária dos Estados, do Distrito Federal ou dos Territórios".

144 "Art. 114. Compete à Justiça do Trabalho conciliar e julgar os dissídios individuais e coletivos entre trabalhadores e empregadores, abrangidos os entes de direito público externo e da administração pública direta e indireta dos Municípios, do Distrito Federal, dos Estados e da União, e, na forma da lei, outras controvérsias decorrentes da relação de trabalho, bem como os litígios que tenham origem no cumprimento de suas próprias sentenças, inclusive coletivas".

Com a Emenda Constitucional n. ${ }^{\circ}$ 45/2004 passou-se a fazer menção a relação de emprego, vejamos:

"Art. 114. Compete à Justiça do Trabalho processar e julgar: (Redação dada pela Emenda Constitucional nº $\underline{45, \text { de 2004) }}$

I as ações oriundas da relação de trabalho, abrangidos os entes de direito público externo e da administração pública direta e indireta da União, dos Estados, do Distrito Federal e dos Municípios; (Incluído pela Emenda $\underline{\text { Constitucional n } n^{\circ} 45 \text {, de 2004) }}$ 
Tal sucede, todavia, somente em relação aos feitos trabalhistas, tanto da União, como do Distrito Federal, dos Estados e dos Municípios. Não com referência aos servidores de vínculo estatutário regular ou administrativo especial, porque o art. 1114 , ora comentado, apenas diz respeito aos dissídios pertinentes a trabalhadores, isto é, ao pessoal regido pela Consolidação das Leis do Trabalho, hipótese que, certamente, não é a presente"

Note-se que o STF, até então, rechaçava a competência da Justiça do Trabalho para julgar servidores estatutários por entender que os termos empregado e trabalhador restringem-se a relações submetidas aos preceitos da CLT. Já nos autos da ADI 492 ${ }^{146}$, processo em que foram declaradas inconstitucionais as alíneas "d" e "e" do art. 240 da Lei n. ${ }^{\circ} 8.112 / 1990^{147}$ que, respectivamente, possibilitava a utilização de negociação coletiva e a conferia à Especializada do Trabalho a competência para julgar litígios entre servidores estatutários e a União Federal, seja ele individual, seja ele coletivo, assentou de modo claro o STF que a incompetência da Justiça do Trabalho decorria da circunstância de os direitos, deveres, garantias e vantagens dos servidores estatutários serem fixados unilateralmente pelo Estado-legislador, como decorrência do princípio da legalidade, vale dizer, em razão de os vínculos estatutários serem incompatíveis com relações de natureza negocial em que há espaço para a autonomia da vontade estabelecer direitos e obrigações, com maior razão frente à impossibilidade de a Administração Pública transigir no que diz respeito a matérias reservadas à lei, o que ocorre com os direitos e deveres dos servidores estatutários.

Sob essa ótica, a Constituição teria reservado o termo trabalhador para se referir a trabalho tutelado nos termos da CLT e, repita-se, que estejam inseridos em relações negociais. É bem verdade que a doutrina trabalhista, como já afirmado no presente estudo, esclarece a distinção entre o gênero, trabalho, e a espécie, emprego. Contudo, o Poder Constituinte parece não reproduzir os ensinamentos da ciência do Direito do Trabalho, como ocorre, por exemplo, com o art. $7^{\circ}$, caput, da Constituição de 1988 , que ao se referir aos direitos dos empregados consigna "são direitos dos trabalhadores urbanos e rurais,

145 BRASIL. Supremo Tribunal Federal. Acórdão no Conflito de Jurisdição n. 6.829-8/SP. Relator: GALLOTTI, Octavio. Publicado no DJ de 14.04.1989. Disponível em: <http://redir.stf.jus.br/paginadorpub/paginador.jsp?docTP=AC\&docID=30325>. Acessado em 30.05.2013.

146 BRASIL. Supremo Tribunal Federal. Acórdão na Ação Direta de Inconstitucionalidade n. 492/DF. Relator: VELLOSO, Carlos. Publicado no DJ de 12.03.1993. Disponível em: <http://www.stf.jus.br/portal/peticaoInicial/verPeticaoInicial.asp?base=ADIN\&s1=492\&processo=492>. Ace ssado em 30.05.2013.

${ }^{147}$ É curioso observar que as normas em evidência, mesmo declaradas inconstitucionais pelo STF em sede de Ação Direta de Inconstitucionalidade, foram revogadas por meio da Lei n. ${ }^{\circ}$ 9.527/1997. 
além de outros que visem à melhoria de sua condição social..."148, vale dizer, em uma interpretação puramente gramatical, a CR utiliza o gênero trabalho para se referir à espécie emprego. Logo, o entendimento do STF imprimi compreensão restritiva ao termo trabalho.

Além disso, ao deferir parcialmente medida cautelar nos autos da ADI 2135, o STF restabeleceu o regime jurídico único para as pessoas jurídicas de Direito Público, respeitada a legislação editada até a data da decisão em razão do efeito ex nunc, próprio da natureza da decisão proferida, o que possibilitou a coexistência de servidores regidos por lei próprio (estatuto) e outros submetidos à CLT.

Interessa esclarecer que o art. 114, I, da CR, acrescentado pela Emenda Constitucional n. ${ }^{\text { }}$ 45/2004, confere à Justiça do Trabalho a competência para processar e julgar “as ações oriundas da relação de trabalho, abrangidos os entes de direito púbico externo e da administração pública direita e indireta da União, dos Estados, do Distrito Federal e dos Municípios" o que acaba por abranger relações contratuais e estatutárias existentes entre a Administração Pública e trabalhadores. Ocorre que o STF, na ADI 3.3956, concedeu liminar com efeito ex tunc suspendendo:

“...toda e qualquer interpretação dada ao inciso I do art. 114 da CF, na
redação dada pela EC $45 / 2004$, que inclua na competência da Justiça do
Trabalho, a .... apreciação... de causas que... sejam instauradas entre o
Poder Público e seus servidores a ele vinculados por típica relação de
ordem estatutária ou de caráter jurídico-administrativo"149.

A ADI em relevo foi proposta pela Associação dos Juízes Federais do Brasil AJUFE e possui como fundamentos alegações de vício formal, supressão de parte do texto aprovado pelo Senado, e de vício material, a dificuldade de interpretação ante a indefinição do que seja relação de trabalho. Note-se que a decisão liminar, da relatoria do então Ministro Cezar Peluso, conferiu interpretação conforme a Constituição de modo a excluir da Justiça Especializada o julgamento de relações de caráter jurídico-administrativa, por entender que elas não se enquadram como relações de trabalho, o que, a seu ver, superaria

\footnotetext{
148 Com entendimento distinto, Ana Cláudia Nascimento Gomes indica a existência de normas constitucionais que tornam clara a distinção entre relação de trabalho e relação de emprego no prórprio texto constitucional, tais como, art. 7º, caput, incisos I, XVIII, XXXIV, XXXIX, art. 195, I e II, e art. 201. Algumas Razões Doutrinárias para se Discordar da Recente (e da Também Antiga) Jurisprudência do Supremo Tribunal Federal Desfavorável à Competência da Justiça do Trabalho em Matéria de Trabalho Prestado a Ente de Direito Público. In: Revista do Ministério Público do Trabalho. Procuradoria-Geral do Trabalho - Ano XXI, março, 2011 - Brasília: Procuradoria Geral do Trabalho, LTr, 2011, pp. 28-29.

${ }^{149}$ BRASIL. Supremo Tribunal Federal. Acórdão na Ação Direta de Inconstitucionalidade (Medida Liminar) n. 3.395/DF. Relator: PELUSO, Cezar. Publicado no DJ de 10.11.2006. Disponível em: <http://www.stf.jus.br/portal/peticaoInicial/verPeticaoInicial.asp?base=ADIN\&s1=3395\&processo=3395>. Acessado em 30.05.2013.
} 
a alegação de vício formal. Data maxima venia, por dizer respeito à atividade humana e primando por interpretações sistemáticas do Direito, as relações estatutárias (jurídicoadministrativas) são espécies de relação de trabalhão, como os são as relações de emprego, de maneira que não há nenhuma cláusula pétrea na Constituição que justifique obstar o desejo do Poder Constituído nem mesmo existe a suposta dubiedade na utilização da expressão relação de trabalho, motivos pelos quais não concordamos com o STF.

Ainda no julgamento da Medida Cautelar em ADI 3.395, o Ministro Joaquim Barbosa sinalizou a incompatibilidade do regime estatutário com relações dotadas de contornos negociais:

\begin{abstract}
"Senhora Presidente, também entendo que a relação entre a Administração e os servidores detentores de vínculo estatutário - legal, portanto - em nada se assemelha à relação contratual que une o trabalhador do setor privado às empresas regidas pela legislação trabalhista. Não há - todos nos sabemos - contornos negociais. São dois universos distintos"
\end{abstract}

Depreende-se, de certa maneira, dos dizeres de mencionado julgador a incompatibilidade do estabelecimento de regime negocial entre os servidores e a Administração Pública, pois inviável a negociação de direitos e deveres. Em complemento, na decisão da Reclamação $5.381-4^{151}$ os Ministros do STF destacaram a existência de distintas interpretações acerca da ADI 3.395-MC ${ }^{152}$. Por ocasião dos debates orais, o Ministro Carlos Brito observou que nos casos de relação estatutária a lei instaura a relação jurídica e dispõe sobre os direitos e obrigações dos que se vinculam com a administração, com a ampla possibilidade de modificação unilateral pelo mesmo meio, o que não se verifica nas relações contratuais, hipótese em que o ato jurídico em sentido lato que serve de causa à relação jurídica estabelece os direitos e obrigações dos sujeitos da relação e apenas podem ser modificados diante de consenso. Impõe destacar a literalidade

\footnotetext{
${ }^{150}$ BRASIL. Supremo Tribunal Federal. Acórdão na Ação Direta de Inconstitucionalidade (Medida Liminar) n. 3.395/DF. Relator: PELUSO, Cezar. Publicado no DJ de 10.11.2006. Disponível em: <http://www.stf.jus.br/portal/peticaoInicial/verPeticaoInicial.asp?base=ADIN\&s1=3395\&processo=3395>. Acessado em 30.05.2013.

${ }^{151}$ BRASIL. Supremo Tribunal Federal. Acórdão na Reclamação Constitucional n. 5.381-4/AM. Relator: BRITTO, Carlos. Publicado no DJ de 08.08.2008. Disponível em: <http://www.stf.jus.br/portal/peticaoInicial/verPeticaoInicial.asp?base=ADIN\&s1=492\&processo=492>. Ace ssado em 30.05.2013.

${ }_{152}$ Ana Cláudia Nascimento Gomes afirma acerca da ADI n. 3.395-MC que "nos seus fundamentados, o Excelso Pretório recordara (e também reavivara) expressamente o seu anterior entendimento, assentado na ADI n.491-1 (1992)...”. Algumas Razões Doutrinárias para se Discordar da Recente (e da Também Antiga) Jurisprudência do Supremo Tribunal Federal Desfavorável à Competência da Justiça do Trabalho em Matéria de Trabalho Prestado a Ente de Direito Público. In: Revista do Ministério Público do Trabalho. ProcuradoriaGeral do Trabalho - Ano XXI, março, 2011 - Brasília: Procuradoria Geral do Trabalho, LTr, 2011, p. 14.
} 
dos dizeres do Ministro Cézar Peluzo que afirmou, com olhos à decisão do STF que restabeleceu o regime jurídico único excluído por força da Emenda Constitucional 19, que:

\begin{abstract}
“em suma, não há possibilidade, na relação jurídica entre servidor e o Poder Público, seja ele permanente ou temporário, de ser regido senão pela legislação administrativa. Chama-se a isso relação estatutária, jurídico-administrativa, ou outro nome qualquer, o certo é que não há relação contratual sujeita à CLT”.
\end{abstract}

Na mesma assentada, os Ministros Cezar Peluso e Cármen Lúcia afirmaram que a disponibilidade, típica de relações contratuais, não pode ser adotada pela Administração Pública frente à prevalência da redação original do art. 39 da CR. Por conseguinte, para o STF a existência de regime jurídico único impõe o estabelecimento de relações estatutárias, não negociais, em que todos os preceitos são fixados e alterados por meio de lei, o que acaba esclarecendo a extensão da decisão proferida na ADI 3.395-MC ${ }^{153}$.

Com isso, a natureza jurídico-administrativa da relação havida entre servidores e Administração Pública, na esteira do entendimento adotado pelo STF, não pode ser afastada, uma vez que o conteúdo da relação é estabelecido em sua integralidade por lei e apenas por esse meio pode ser alterado, independentemente de qualquer concordância do servidor.

Atente-se, com vistas à Administração Federal, que são de iniciativa privativa do Presidente da República as leis que disponham sobre a criação ou aumento de remuneração de cargos, funções ou empregos, consoante o disposto no art. 61, §1º, II, “a", da $\mathrm{CR}^{154}$. Vale notar, ainda, que o próprio Presidente da República possui limitações impostas pela Constituição para a criação de cargos, funções ou empregos, para a concessão de vantagem ou aumento de remuneração e, também, para a admissão ou contratação, destacam-se entre as exigências a necessidade de prévia dotação orçamentária para atender às projeções de

\footnotetext{
${ }^{153}$ Carlos Eduardo de Azevedo Lima destaca que "tem o Supremo Tribunal Federal, portanto, ampliado em demasia a decisão da ADI n. 3.395, de forma a contrariar o que havia sido decidido nos votos emitidos por seus próprios ministros". A Justiça do Trabalho e a Competência para o Processamento e Julgamento de Causas Envolvendo Trabalhadores Vinculados à Administração Pública: Algumas Reflexões. In: Revista do Ministério Público do Trabalho. Procuradoria-Geral do Trabalho - Ano XX, março, 2010 - Brasília: Procuradoria Geral do Trabalho, LTr, 2010, p. 257.

154 "Art. 61. A iniciativa das leis complementares e ordinárias cabe a qualquer membro ou Comissão da Câmara dos Deputados, do Senado Federal ou do Congresso Nacional, ao Presidente da República, ao Supremo Tribunal Federal, aos Tribunais Superiores, ao Procurador-Geral da República e aos cidadãos, na forma e nos casos previstos nesta Constituição.

$\S 1^{\circ}$ - São de iniciativa privativa do Presidente da República as leis que:

(...)

II - disponham sobre:

a) criação de cargos, funções ou empregos públicos na administração direta e autárquica ou aumento de sua remuneração;".
} 
despesas e a autorização específica na lei de diretrizes orçamentárias, preceito último não aplicável às empresas públicas e às sociedades de economia mista ${ }^{155}$. Assim, a criação de postos de trabalho, seu preenchimento, a concessão de vantagens e de aumento de remuneração são matérias que apenas podem ser tratadas por lei em sentido estrito, o que indica a necessidade de severa observância do princípio da legalidade.

Observe-se que as empresas estatais não têm a concessão de direitos ou aumentos vinculados à previa estipulação por meio de lei, isso em razão da ausência de menção no art. 169 , caput, da CR, tanto em sua redação original ${ }^{156}$, como na redação estabelecida desde a Emenda Constitucional n. ${ }^{\circ} 19$, e notadamente frente à previsão do art. $173, \S 1^{\circ}$, II, da $\mathrm{CR}^{157}$, que as impõem à sujeição ao regime jurídico próprio das empresas privadas quanto aos direitos e obrigações trabalhistas.

Outro dado relevante, em 7 de março de 2013 foi publicado o Decreto n. ${ }^{\circ}$ 7.944/2013 que promulgou a Convenção 151 da Organização Internacional do Trabalho OIT sobre as Relações de Trabalho na Administração Público. Segundo esse diploma normativo é possível a regulamentação das condições de trabalho por meio de negociação coletiva ou com a utilização de outros meios que permitam a participação dos

\footnotetext{
155 “Art. 169. A despesa com pessoal ativo e inativo da União, dos Estados, do Distrito Federal e dos Municípios não poderá exceder os limites estabelecidos em lei complementar. (Redação dada pela pela Emenda Constitucional $\mathrm{n}^{\circ} 19$, de 1998)

$\S 1^{\circ}$ A concessão de qualquer vantagem ou aumento de remuneração, a criação de cargos, empregos e funções ou alteração de estrutura de carreiras, bem como a admissão ou contratação de pessoal, a qualquer título, pelos órgãos e entidades da administração direta ou indireta, inclusive fundações instituídas e mantidas pelo poder público, só poderão ser feitas: (Renumerado do parágrafo único, pela Emenda Constitucional n ${ }^{\circ}$ 19, de 1998)

I - se houver prévia dotação orçamentária suficiente para atender às projeções de despesa de pessoal e aos acréscimos dela decorrentes; (Incluído pela Emenda Constitucional no 19, de 1998)

II - se houver autorização específica na lei de diretrizes orçamentárias, ressalvadas as empresas públicas e as sociedades de economia mista. (Incluído pela Emenda Constitucional n 19 , de 1998)".

156 "Art. 169. A despesa com pessoal ativo e inativo da União, dos Estados, do Distrito Federal e dos Municípios não poderá exceder os limites estabelecidos em lei complementar.

Parágrafo único. A concessão de qualquer vantagem ou aumento de remuneração, a criação de cargos ou alteração de estrutura de carreiras, bem como a admissão de pessoal, a qualquer título, pelos órgãos e entidades da administração direta ou indireta, inclusive fundações instituídas e mantidas pelo Poder Público, só poderão ser feitas:".

157 “Art. 173. Ressalvados os casos previstos nesta Constituição, a exploração direta de atividade econômica pelo Estado só será permitida quando necessária aos imperativos da segurança nacional ou a relevante interesse coletivo, conforme definidos em lei.

$\S 1^{\circ}$ A lei estabelecerá o estatuto jurídico da empresa pública, da sociedade de economia mista e de suas subsidiárias que explorem atividade econômica de produção ou comercialização de bens ou de prestação de serviços, dispondo sobre: (Redação dada pela Emenda Constitucional nº 19, de 1998)

(...)

II - a sujeição ao regime jurídico próprio das empresas privadas, inclusive quanto aos direitos e obrigações civis, comerciais, trabalhistas e tributários; (Incluído pela Emenda Constitucional nº 19, de 1998)”.
} 
representantes dos trabalhadores em sua fixação ${ }^{158}$. Com arrimo nessa diretriz, pode-se afirmar que houve a quebra do monismo de fontes no estabelecimento de condições de trabalho nas relações estatutárias, contudo, impera recordar que norma semelhante foi declarada inconstitucional pelo STF no julgamento da ADI 492. À margem do entendimento do STF sobre a negociação coletiva nas relações estatutárias, cumpre indagar se a novidade introduzida dá contornos contratuais ou negociais às relações estatutárias. Cumpre lembrar que a negociação coletiva é realizada entre sindicatos ou entre o sindicato dos trabalhadores e algum empregador, e dela pode resultar a celebração de convenção ou acordo coletivo, de observância obrigatória nas relações de emprego estabelecidas, como determina o art. 619 da CLT $^{159}$. A necessária observância das normas decorrentes de negociação coletiva revela a pluralidade de fontes do Direito do Trabalho, todavia, caso não seja acompanhada da possibilidade de os próprios sujeitos da relação jurídica estipularem direitos, sua natureza não será contratual ou negocial, mas, sim, de ato jurídico que possui todas as suas repercussões estabelecidas em lei, uma vez que não se dá relevo para manifestações individuais.

Mas há de se verificar a compatibilidade da convenção com as normas próprias do Direito Constitucional acerca de direitos e obrigações de servidores, tendo em vista a submissão ao princípio da legalidade, nomeadamente as mencionadas em parágrafos anteriores.

Também merece lembrança a Lei Complementar 101/2000, Lei de Responsabilidade Fiscal, que estabelece normas de finanças públicas voltadas para a responsabilidade na gestão fiscal e se aplica à União, aos Estados, ao Distrito Federal e aos Municípios. Encontramos no diploma normativo em referência, especificamente em seu art. $21^{160}$, a vinculação de qualquer aumento de despesas com pessoal, rubrica em que se

\footnotetext{
158 “Art. 7 - Deverão ser adotadas, sendo necessário, medidas adequadas às condições nacionais para estimular e fomentar o pleno desenvolvimento e utilização de procedimentos de negociação entre as autoridades públicas competentes e as organizações de empregados públicos sobre as condições de emprego, ou de quaisquer outros métodos que permitam aos representantes dos empregados públicos participar na determinação de tais condições.

159 “Art. 619. Nenhuma disposição de contrato individual de trabalho que contrarie normas de Convenção ou Acôrdo Coletivo de Trabalho poderá prevalecer na execução do mesmo, sendo considerada nula de pleno direito. (Redação dada pelo Decreto-lei no 229, de 28.2.1967)".

160 “Art. 21. É nulo de pleno direito o ato que provoque aumento da despesa com pessoal e não atenda:

I - as exigências dos arts. 16 e 17 desta Lei Complementar, e o disposto no inciso XIII do art. 37 e no $\S 10$ do art. 169 da Constituição;

II - o limite legal de comprometimento aplicado às despesas com pessoal inativo.
} 
inserem a criação de cargos e empregos e a concessão de direitos segundo a Lei 4320/1964, estão vinculado à previa autorização em lei, excepcionadas somente às empresas estatais sem dependência do Estado ${ }^{161}$, que a teor do art. $2^{\circ}$, II e III, da Lei de Responsabilidade Fiscal, são aquelas em que a maioria do capital social com direito a voto pertença a ente da Federação e que recebam recursos financeiros para pagamento de despesas com pessoal, de custeio em geral ou de capital ${ }^{162}$. Assim, empresas estatais sem dependência econômica de ente da Federação não se submetem à Lei Complementar $101 / 2000$.

A teor do art. 37, XIX, da CR, a criação de empresas estatais depende de autorização legislativa. Note-se, também, que cada ato de instituição das empresas estatais disporá sobre a atribuição de criação de empregos ou de quadro de pessoal, como ocorreu, por exemplo, com Caixa Econômica Federal, empresa pública instituída pelo Decreto 66.303/1970, que impõe à Diretoria a atribuição de apreciar e aprovar para decisão final do Ministro da Fazenda o quadro de pessoal da empresa ${ }^{163}$, sem a necessidade de lei para sua fixação.

Parágrafo único. Também é nulo de pleno direito o ato de que resulte aumento da despesa com pessoal expedido nos cento e oitenta dias anteriores ao final do mandato do titular do respectivo Poder ou órgão referido no art. 20".

161 "Art. 1o Esta Lei Complementar estabelece normas de finanças públicas voltadas para a responsabilidade na gestão fiscal, com amparo no Capítulo II do Título VI da Constituição.

$\S 1$ A responsabilidade na gestão fiscal pressupõe a ação planejada e transparente, em que se previnem riscos e corrigem desvios capazes de afetar o equilíbrio das contas públicas, mediante o cumprimento de metas de resultados entre receitas e despesas e a obediência a limites e condições no que tange a renúncia de receita, geração de despesas com pessoal, da seguridade social e outras, dívidas consolidada e mobiliária, operaçães de crédito, inclusive por antecipação de receita, concessão de garantia e inscrição em Restos a Pagar.

$\S 20$ As disposições desta Lei Complementar obrigam a União, os Estados, o Distrito Federal e os Municípios.

$\S 3$ o Nas referências:

I - à União, aos Estados, ao Distrito Federal e aos Municípios, estão compreendidos:

a) o Poder Executivo, o Poder Legislativo, neste abrangidos os Tribunais de Contas, o Poder Judiciário e o Ministério Público;

b) as respectivas administrações diretas, fundos, autarquias, fundações e empresas estatais dependentes;".

162 "Art. 20 Para os efeitos desta Lei Complementar, entende-se como:

I - ente da Federação: a União, cada Estado, o Distrito Federal e cada Município;

II - empresa controlada: sociedade cuja maioria do capital social com direito a voto pertença, direta ou indiretamente, a ente da Federação;

III - empresa estatal dependente: empresa controlada que receba do ente controlador recursos financeiros para pagamento de despesas com pessoal ou de custeio em geral ou de capital, excluídos, no último caso, aqueles provenientes de aumento de participação acionária;".

163 “4.3 - Compete à Diretoria o exercício das atribuições deliberativas da CEF e ainda:

(...)

4.3.5 - apreciar e aprovar, para final decisão do Ministro da Fazenda, o quadro de pessoal da emprêsa, as propostas de criação de emprêgo e fixação de salários, as propostas de requisição de servidores, de acôrdo com o subitem 812 , e as propostas de contratação, na forma do subitem $813 ; ”$. 
De acordo com a Constituição do Estado de São Paulo a criação de cargos, empregos e funções na Administração Direta e autárquica é feita por meio de lei de iniciativa do Governador do Estado ${ }^{164}$, cumprindo observar que leis que criem cargos no Poder Judiciário e no Poder Legislativa são de atribuição de cada um desses Poderes respectivamente $^{165166}$. Veja-se que o texto do documento maior do Estado de São Paulo estabelece, por exclusão, ao se referir somente à Administração Direta e autárquica, que criação de empregos nas empresas estatais não depende de lei.

Por sua vez, a Constituição do Estado de Minas Gerais impõe a exigência de lei para a criação de cargos na Administração Direta, autárquica e fundacional ${ }^{167}$. Acerca das empresas estatais, a Constituição do Estado de Minas Gerais consigna a atribuição do Governador do Estado para dar iniciativa ao projeto de lei que diga respeito ao quadro de

164 “Artigo 24 - A iniciativa das leis complementares e ordinárias cabe a qualquer membro ou comissão da Assembleia Legislativa, ao Governador do Estado, ao Tribunal de Justiça, ao Procurador-Geral de Justiça e aos cidadãos, na forma e nos casos previstos nesta Constituição.

(...)

$\S 2^{\circ}$ - Compete, exclusivamente, ao Governador do Estado a iniciativa das leis que disponham sobre:

1 - criação e extinção de cargos, funções ou empregos públicos na administração direta e autárquica, bem como a fixação da respectiva remuneração;”.

165 “Artigo 20 - Compete exclusivamente à Assembleia Legislativa:

I - eleger a Mesa e constituir as comissões;

II - elaborar seu Regimento Interno;

III- dispor sobre a organização de sua Secretaria, funcionamento, polícia, criação, transformação ou extinção dos cargos, empregos e funções de seus serviços e a iniciativa de lei para fixação da respectiva remuneração, observados os parâmetros estabelecidos na lei de diretrizes orçamentárias;"”.

166 “Artigo 24 - A iniciativa das leis complementares e ordinárias cabe a qualquer membro ou comissão da Assembleia Legislativa, ao Governador do Estado, ao Tribunal de Justiça, ao Procurador-Geral de Justiça e aos cidadãos, na forma e nos casos previstos nesta Constituição.

(...)

$\S 4^{\circ}$ - Compete, exclusivamente, ao Tribunal de Justiça a iniciativa das leis que disponham sobre:

1 - criação e extinção de cargos e a remuneração dos seus serviços auxiliares e dos juízos que lhes forem vinculados, bem como a fixação do subsídio de seus membros e dos juízes, incluído o Tribunal de Justiça Militar;".

167 “Art. 66 - São matérias de iniciativa privativa, além de outras previstas nesta Constituição:

I - da Mesa da Assembleia:

(...)

d) a organização da Secretaria da Assembleia Legislativa, seu funcionamento e sua polícia, a criação, a transformação ou a extinção de cargo, emprego e função e o regime jurídico de seus servidores;

(...)

III - do Governador do Estado:

(...)

b) a criação de cargo e função públicos da administração direta, autárquica e fundacional e a fixação da respectiva remuneração, observados os parâmetros da Lei de Diretrizes Orçamentárias;

(...)

IV - do Tribunal de Justiça, por seu Presidente:

a) a criação e a organização de juízo inferior e de vara judiciária, a criação e a extinção de cargo e função públicos e a remuneração dos seus serviços auxiliares e dos juízos que lhe forem vinculados, bem como a fixação do subsídio de seus membros e dos juízes, observados os parâmetros estabelecidos na Lei de Diretrizes Orçamentárias e o disposto nos arts. 24 e 32 desta Constituição;”. 
pessoal das empresas estatais ${ }^{168}$, contudo, não deixa clara a extensão da regulamentação, vale dizer, se a criação de cada uma dos empregos em empresas estatais depende de autorização legislativa.

Frente ao conteúdo dos parágrafos precedentes, pode-se afirmar que, ao identificar a legislação trabalhista com o regime negocial, o STF impõe restrição à competência da Justiça do Trabalho, pois somente lhe atribui a competência para processar e julgar litígios que digam respeito a prestadores de trabalho regidos pela CLT, desde que essa consolidação não seja simulacro de estatuto, recaindo sobre a Justiça Comum Estadual a competência para processar e julgar litígios sobre relações de servidores municipais e estaduais e sobre a Justiça Federal, as relações entre servidores federais e a União Federal $^{169}$. Além disso, o STF também restringe a competência da Justiça Especializada ao entender, segundo a fundamentação da Reclamação 5.381-4, que os servidores vinculados às pessoas jurídicas de Direito Público sempre são regidos por legislação jurídicoadministrativa, inexistindo a possibilidade de regime negocial, mesmo que se submetam à CLT, uma vez que inexistirá possibilidade de transação sobre direitos e obrigações.

Nessa linha, a singela menção por meio normativo de que aos servidores de determinada pessoa jurídica de Direito Público se aplica a CLT não tem o condão de validamente transformar essa relação jurídica em negocial, isso em razão das amarras constitucionais, como o art. $37, \mathrm{X}$, da $\mathrm{CR}^{170}$, que visam à tutela do interesse público. Enfim, mesmo em casos como o do Município de Poços de Caldas, Minas Gerais, que se vincula com seus servidores por meio da CLT (Lei Complementar 25/2002), não haveria espaço para a estipulação de direitos e obrigações por consenso entre empregado e empregador, uma vez que eles decorrem de imposição legal, como se dá com a fixação da jornada ${ }^{171}$ e do salário ${ }^{172}$. Em cenários como este, em que pese a legislação do ente desejar

168 “III - do Governador do Estado:

(...)

d) o quadro de empregos das empresas públicas, sociedades de economia mista e demais entidades sob controle direto ou indireto do Estado;".

${ }^{169}$ Vale registrar que o entendimento do STF empolgou o cancelamento da OJ 205 da SDI1 do TST, que já havia cancelado a OJ 263 do mesmo órgão esperançoso com aparente ampliação de competência proporcionada pela Emenda Constitucional n. ${ }^{\circ}$ 45/2004.

170 "X - a remuneração dos servidores públicos e o subsídio de que trata o $\$ 4^{\circ}$ do art. 9 somente poderão ser fixados ou alterados por lei específica, observada a iniciativa privativa em cada caso, assegurada revisão geral anual, sempre na mesma data e sem distinção de índices".

171 "Art. 18 - A duração normal do trabalho, a ser cumprida por todos os empregados da mesma classe será como indicado nos Anexos, correspondente:....".

172 "Art. 19 - Os valores dos níveis salariais indicados nos Anexos corresponderão à duração normal do trabalho pertinente aos Empregos da classe". 
submeter servidores e Administração Pública à CLT ${ }^{173}$, a natureza jurídica do ato que serve de causa da relação jurídica ou como fixador de seus deveres e obrigações é estranho ao negócio jurídico, vale dizer, não podem ser estabelecidos ao talante dos envolvidos.

Efetivamente, as pessoas jurídicas de Direito Público ao pretenderem a utilização da CLT na vinculação com seus servidores não podem transformar uma relação com objetos fixados somente por lei em negocial, em tais casos ocorrerá exclusivamente o aproveitamento da CLT como estatuto básico, de maneira que todos os litígios decorrentes de relações entre servidores e pessoas jurídicas de Direito Público refogem da competência da Justiça do Trabalho, ao menos enquanto o STF conservar esse entendimento.

Independentemente do regime jurídico escolhido e da competência para processamento e julgamento de litígios, podem surgir dúvidas quanto a quem deva ocupar os cargos ou empregos públicos. A solução desses questionamentos varia em razão da opção feita pelos exercentes do Poder Constituinte, isto é, de acordo com as regras por eles estabelecidas e com os princípios vetores da Administração Pública. O art. $37^{174}$, caput, da Constituição destacou como princípios da Administração Pública os seguintes: legalidade, impessoalidade, moralidade, publicidade e eficiência.

O princípio da publicidade consagra o dever de a Administração manter a transparência de seus comportamentos, pois em um Estado Democrático de Direito não podem existir atos ocultos ao povo ${ }^{175}$.

Extrai-se do princípio da moralidade o dever da Administração e do administrado que com ela se relacione atuar com a observância da ética, dos bons costumes e das regras de boa administração, e não somente com a observância dos importantes ditames legais ${ }^{176}$. Igualmente, a CR, ao consagrar o princípio da moralidade como diretriz da Administração Pública impõe a punição dos administradores públicos imorais ou amorais. Com efeito, o

\footnotetext{
173 “Art. $1^{\text {o }}$ - Esta lei institui o Plano de Empregos, Carreiras e Salários do quadro de pessoal da Prefeitura Municipal de Poços de Caldas, regido pela CLT - Consolidação das Leis do Trabalho, aprovada pelo Decreto-lei 5452, de $1^{\circ}$ de maio de 1945 e legislação trabalhista correlata, naquilo que esta lei não dispuser em contrário".

174 “Constituição da República. Art. 37. A administração pública direta e indireta de qualquer dos Poderes da União, dos Estados, do Distrito Federal e dos Municípios obedecerá aos princípios de legalidade, impessoalidade, moralidade, publicidade e, também, ao seguinte:".

${ }^{175}$ MELLO, Celso Antônio Bandeira de. Curso de Direito Administrativo. 22.ed. São Paulo: Malheiros, 2007, p. 110.

${ }^{176}$ DI PIETRO, Maria Sylvia Zanella. Direito Administrativo. 17.ed. São Paulo: Atlas, 2004, p. 79.
} 
controle jurisdicional dos atos administrativos não se esvai com a análise de sua legalidade, abrangendo também a aferição da moral administrativa ${ }^{177}$.

Registre-se, por oportuno, a expressa menção à punição do administrador público faltoso com a moralidade $\S 4^{\circ}$ do no art. 37 da Constituição. Há, também, a densificação da proposição constitucional na Lei $n^{\circ} 8.429 / 1992$, diploma normativo que tipifica uma série de condutas como improbidade administrativa.

Já o princípio da impessoalidade representa a impossibilidade de a Administração atuar para prejudicar ou favorecer pessoas determinadas. Essa concepção deriva da necessidade de prevalência do interesse público, ou, se se preferir, da imposição dos interesses primários da sociedade sobre os interesses dos particulares. Há, ainda, uma segunda compreensão segundo a qual os atos administrativos são imputáveis à própria Administração e não ao funcionário que os pratica $^{178}$.

Por sua vez, a eficiência apresenta dois aspectos: pode ser considerada como o modo de atuação do agente público ou como o modo de organização e estruturação da Administração Pública ${ }^{179}$. Nota-se, em ambas as compreensões, que a eficiência é vista como a obtenção de melhores resultados com o menor custo e, de igual maneira, o atendimento do interesse público da melhor maneira possível.

Há grande vinculação dos princípios lembrados nos parágrafos anteriores com o concurso público, pois a observância da imparcialidade garante que a escolha do ocupante do cargo ou emprego público será feita mediante parâmetros neutros que avaliem a aptidão e o preparo do candidato. Outrossim, o respeito à eficiência será pelo processo de seleção racional que escolha a pessoa melhor preparada para o desempenho das atribuições, trazendo melhores resultados à Administração na consecução de seus objetivos.

Por derradeiro, o princípio da legalidade representa o propósito político de submeter os agentes públicos em geral a um quadro normativo que embargue favoritismos, perseguições ou desmandos ${ }^{180}$. Ele pretende, ainda, a atuação da Administração nos estreitos parâmetros do estabelecido pelas normas jurídicas. O estabelecimento de vínculo

\footnotetext{
${ }^{177}$ MORAES, Alexandre. Constituição do Brasil interpretada e legislação constitucional. 2. ed. São Paulo: Atlas, 2003, p. 787.

${ }^{178}$ DI PIETRO, Maria Sylvia Zanella. Direito Administrativo. 17.ed. São Paulo: Atlas, 2004, p. 71.

${ }^{179}$ Ibidem, p. 83.

${ }^{180}$ MELLO, Celso Antônio Bandeira de. Curso de Direito Administrativo. 22.ed. São Paulo: Malheiros, 2007, p. 97.
} 
jurídico entre a Administração Pública e os servidores públicos diz respeito ao preenchimento substancial da atividade necessária ao atendimento do interesse público, de modo que costuma ser tratado pelas normas de maior envergadura na ordem jurídica. As normas constitucionais sobre a ocupação de cargos e empregos públicos indicam que a investidura depende de aprovação em concurso público ${ }^{181}$ de provas ou de provas e títulos, de acordo com a natureza e a complexidade do cargo ou emprego, em conformidade com o estabelecido em lei.

O amplo acesso por concurso público é estabelecido pelo art. 37, II, da CR, proposição prescritiva que é complementada pelo $\S 2^{\circ}$ do mesmo artigo, que reputa nulo o ato de contratação à míngua de prévia aprovação em certame, além de determinar a punição da autoridade responsável. Ao lado da regra geral, encontramos no mesmo art. 37, II, a dispensa do concurso público nos casos de nomeações para cargos em comissão, declarados em lei de livre nomeação e exoneração. Mas não é só, além dos cargos em comissão, há outras exceções no texto constitucional, por exemplo, as nomeações dos membros de Tribunais (arts. 73, $\$ 2^{\circ}, 94$, etc).

A história já registrou pelo menos sete modos de provimento de cargos públicos: hereditariedade, venalidade, arrendamento, sorteio, eleição, nomeação direta e nomeação mediante concurso ${ }^{182}$. A ordem jurídica brasileira, de modo diverso do verificado em outros países, como a Itália ${ }^{183}$, em que a legislação ordinária pode estipular procedimentos de seleção diversos do concurso público, prevê, regra geral, o concurso público como o método de seleção por excelência, sem qualquer possibilidade de abrandamento pela normatização comum, pois as exceções são taxativamente enumeradas em normas constitucionais, como visto.

\footnotetext{
${ }^{181}$ Registra Raquel Discacciati Bello que "o vocábulo "concurso" deriva do latim concursus, formado pelo verbo con, que significa convergência, e do nome curso, que quer dizer corrida, carreira. Etinologicamente, significa carreira para determinado lugar. Tem sentido analógico a concorrência, onde várias pessoas participam de um mesmo ato. Pode significar, além da disputa, a simples conjunção ou integração de coisas ou pessoas". In: BELLO, Raquel Discacciati. O princípio da igualdade no concurso publico. Revista de Informação Legislativa. Brasília. v.33. n.131. p.313-20. jul./set. 1996, p. 316-317.

${ }^{182}$ PEREIRA JUNIOR, Jesse Torres. Repercussões da emenda constitucional 19 sobre os concursos para provimento de cargos e empregos públicos. Revista de Direito Constitucional e Internacional. São Paulo. v.8. n.32. jul./set. 2000. p.211.

${ }^{183}$ Segundo Angelina-Maria Perrino "soltanto alla legge è riservata, dal terzo comma dell'art. 97, la possibilita di derogare al princípio del concorso, "...lasciando libero il legislatore diadottare sistemi diversi, purché anch'essi congrui e ragionevoli in raporto al fine da raggiungere e all'interesse da soddisfare." In: PERRINO, Angelina-Maria. Il rapporto di lavoro pubblico. Padova: CEDAM, 2004, p. 123.
} 
Identifica-se no Direito italiano a possibilidade de métodos de seleção que não resultam, necessariamente, na escolha do candidato melhor classificado e, ainda, a possibilidade de concursos internos que possibilitam tão somente a participação de integrantes de determinado ente ou órgão ${ }^{184}$. No caso brasileiro, à margem de autorização constitucional, são inválidas as seleções internas, o que acaba por proibir preferências por aqueles que já tenham experiência pregressa na Administração ${ }^{185}$, bem como os concursos públicos que não se amparam em provas ou em provas e títulos, pois violam o amplo acesso estipulado no já mencionado art. 37, II.

Portanto, pode-se dizer que o concurso público representa o instrumento de realização dos princípios da igualdade, da impessoalidade e da moralidade administrativa $^{186}$, pois proporciona, ao menos como possibilidade, o acesso de todos aos cargos públicos. Considerar o concurso público um instrumento, isto é, um meio de realização de algo, não impede sua compreensão por outras perspectivas, como o conjunto de normas que se ocupa das especificidades dos certames ou, ainda, como princípio que conduz a Administração Pública ${ }^{187}$.

O estipulado no art. 37, II, seria facilmente ignorado caso não fosse acompanhado pelas previsões dos $\S \S 2^{\circ}$ e $4^{\circ}$ do mesmo artigo. A primeira das menções qualifica como nulo o ato de contratação ao arrepio do mandamento constitucional da necessidade de prévia aprovação em concurso público, ao passo que o segundo parágrafo mencionado deixa claras as consequências jurídicas ou sanções para o administrador público que pratica ato de improbidade pública, o que inclui a violação ao concurso público ${ }^{188}$.

\footnotetext{
${ }^{184}$ GENTILLE, Giuseppe. Il diritto del lavoro. Volume III: Il lavoro pubblico. 2.ed. Giuffrè Editore. pp. 364 a 367.

${ }^{185}$ REIS, Carlos David Santos Aarão. O princípio da igualdade nos concursos públicos. Revista de Ciência Política. Rio de Janeiro. v.32. n.3. p.31-41. maio/jul. 1989, p. 32.

${ }^{186}$ Merece menção a definição dada pelo Ministro Celso de Mello à fl. 628 dos autos do MS 21.322 - DF "É preciso ter presente, enfim, que o legislador constituinte, ao prestigiar, em sua máxima extensão, o postulado do concurso público, quis, na realidade, consagrá-lo como instrumento concretizador dos princípios da isonomia, da impessoalidade e da moralidade administrativa."

187 RECRUTAMENTO e seleção de pessoal: validade dos procedimentos. BDA: Boletim de Direito Administrativo. São Paulo. v.10. n.9. p.542-6. set. 1994.

188 Thiago Emmanuel Chaves de Lima observa que "para concretizar os princípios da impessoalidade e moralidade, a Constituição da República trouxe para o ordenamento jurídico o princípio do concurso público (art. 37, II). A Lei n. ${ }^{\circ} 8.429 / 93$, dando eficácia ao art. 37, $\$ 4^{\circ}$, da CF, arrola, nos artigos $9^{\circ}$, 10 e 11 , os atos tipificados como improbidade administrativa, classificando-os, de acordo com o bem jurídico violado, em atos de improbidade que importam enriquecimento ilícito, que causam prejuízo ao erário e que violam os princípios da administração pública. Ela prevê expressamente que constitui ato de improbidade que atenta contra os princípios da administração pública a violação dos deveres de honestidade, imparcialidade, legalidade e, notadamente, frustrar a licitude de concurso público". In: LIMA, Thiago Emmanuel Chaves de.
} 
Logo, a diretriz geral do Texto Maior de 1988 é o amplo acesso aos cargos públicos por intermédio de concurso público, mas isso nem sempre ocorreu, como se destacará no tópico seguinte.

\section{Concurso público no histórico constitucional brasileiro.}

O princípio do amplo acesso aos cargos públicos é contemporâneo ao constitucionalismo moderno, seu reconhecimento ocorreu conjuntamente com os chamados direitos de primeira dimensão, que compreendem além das liberdades públicas o direito de participação política. Fabiano Holz Beserra destaca que o art. VI da Declaração Universal dos Direitos do Homem e do Cidadão já previa o acesso igualitário aos cargos públicos, o que também foi consagrado no art. $21\left(2^{\circ}\right)$ da Declaração dos Direitos do Homem de $1948^{189}$.

Após breve destaque da prodigiosa previsão internacional, passemos à análise da realidade local.

Conquistada ou afirmada a independência do Brasil em 1822, tem incoação a busca por uma Constituição, diploma normativo que fosse capaz de organizar politicamente esse novo Estado, conferindo direito fundamentais e distribuindo o poder ${ }^{190}$. No entanto, os interesses do Imperador na mencionada distribuição dos poderes acabaram por dissolver a Assembleia Constituinte instalada em 3 de maio de 1823. Segundo Sahid Maluf, a ausência de êxito das tratativas constitucionais foi pronunciada desde seu

A violação do princípio do concurso público como ato de improbidade administrativa. Fórum Administrativo. Belo Horizonte. v.11. n.128. p.30-41. out. 2011, p. 30.

${ }^{189}$ BESERRA, Fabiano Holz. Ação civil pública e relações de trabalho: tutela da moralidade e da probidade administrativa. Rio de Janeiro: Forense. São Paulo: Método. 2008, p. 36.

190 “O constitucionalismo no Brasil coincide com a sua emancipação política. Ambos datam de 1822.

Não que o Brasil somente se tenha constitucionalizado após a Independência. Não; já antes Portugal substituira o seu regime absolutista por um francamente constitucional, apesar de monárquico, e isso em virtude de queda, em toda a Europa, do princípio do absolutismo dos reis.

Essa adoção do constitucionalismo pela Metrópole, evidentemente, teria que se refletir no Brasil, que, como colônia que era, aceitou, como não poderia deixar de ser, a transformação operada no Reino. Latente, entretanto, já vivia na alma popular brasileira o espírito de independência, fertilizado, irrigado, vicejado pelo sangue que, prodigamente, a 21 de abril de 1789, gôta a gôta, o Mártir Tiradentes ofertada ao Brasil, de seu patíbulo no largo da Lampadosa. Esse sangue, assim tão espontâneo e dadivosamente doado à Pátria e ao seu povo, penetrou paulatinamente mas firmemente, pelas entranhas do solo que irrigara a três décadas depois explodiu num ímpeto, num repente, numa afirmação irrefreável de nacionalidade, dizendo ao mundo que aqui, nos confins do Novo Continente, um povo se tornara adulto, um povo era senhor dos seus destinos, um povo era livre e se erigia em país soberano. Era a Independência que nascia, recebendo seu batismo no alto do Ipiranga". In: SILVA, Héber Americano. Direito constitucional: o homem e a sociedade o Estado constitucional brasileiro. $1^{\mathrm{o}}$ volume, $2^{\mathrm{a}}$ edição. Bauru: Jalovi, 1971, p. 74. 
nascedouro, uma vez o detentor do poder imperial asseverou que defenderia com a sua espada a Constituição que a Assembleia fizesse, se fosse digna dele ${ }^{191}$.

\section{Uma nova Assembleia foi instituída e trouxe como fruto a Constituição Política} do Império, de $1824^{192}$, que consagrava no Título $8^{\circ}$, art. $179^{193}$, direitos fundamentais, entre os quais encontramos a igualdade perante a lei ${ }^{194}$, o amplo acesso aos cargos públicos ${ }^{195}$ e a abolição de privilégios ${ }^{196}$. Todavia, as impressões favoráveis ao amplo acesso aos postos públicos foram mitigadas por disposições de igual hierarquia, dispostas em artigos que precederam a consagração dos direitos fundamentais. Na mesma direção, não se pode olvidar a existência de um quarto Poder, o Moderador ${ }^{197}{ }^{198}$, que acabava por

${ }^{191}$ MALUF, Sahid. Curso de direito constitucional. 2. v. parte especial. 6.e.d. Sugestões Literárias S.A., 1972, p. 9.

192 Ibidem, p. 10.

193 “Art. 179. A inviolabilidade dos Direitos Civis, e Politicos dos Cidadãos Brazileiros, que tem por base a liberdade, a segurança individual, e a propriedade, é garantida pela Constituição do Imperio, pela maneira seguinte".

194 "XIII. A Lei será igual para todos, quer proteja, quer castigue, o recompensará em proporção dos merecimentos de cada um".

195 "XIV. Todo o cidadão pode ser admittido aos Cargos Publicos Civis, Politicos, ou Militares, sem outra differença, que não seja dos seus talentos, e virtudes".

196 "XVI. Ficam abolidos todos os Privilegios, que não forem essencial, e inteiramente ligados aos Cargos, por utilidade publica".

197 “Art. 98. O Poder Moderador é a chave de toda a organisação Politica, e é delegado privativamente ao Imperador, como Chefe Supremo da Nação, e seu Primeiro Representante, para que incessantemente vele sobre a manutenção da Independencia, equilibrio, e harmonia dos mais Poderes Politicos.

Art. 99. A Pessoa do Imperador é inviolavel, e Sagrada: Elle não está sujeito a responsabilidade alguma.

Art. 100. Os seus Titulos são "Imperador Constitucional, e Defensor Perpetuo do Brazil" e tem o Tratamento de Magestade Imperial.

Art. 101. O Imperador exerce o Poder Moderador

I. Nomeando os Senadores, na fórma do Art. 43.

II. Convocando a Assembléa Geral extraordinariamente nos intervallos das Sessões, quando assim o pede o bem do Imperio.

III. Sanccionando os Decretos, e Resoluções da Assembléa Geral, para que tenham força de Lei: Art. 62. IV. Approvando, e suspendendo interinamente as Resoluções dos Conselhos Provinciaes: Arts. 86, e 87.

V. Prorogando, ou adiando a Assembléa Geral, e dissolvendo a Camara dos Deputados, nos casos, em que o exigir a salvação do Estado; convocando immediatamente outra, que a substitua.

VI. Nomeando, e demittindo livremente os Ministros de Estado.

VII. Suspendendo os Magistrados nos casos do Art. 154.

VIII. Perdoando, e moderando as penas impostas e os Réos condemnados por Sentença.

IX. Concedendo Amnistia em caso urgente, e que assim aconselhem a humanidade, e bem do Estado".

${ }^{198}$ Luiz Alberto David Araújo e Vidal Serrano Nunes Júnior registram sobre a Constituição de 1824 que "não adotou a separação tripartida do poder. Seguindo as idéias de Benjamin Constant, a Constituição do Império tinha um Poder Moderador, ao lado da divisão clássica. Assim, encontraremos o Poder Moderador, o Poder Judiciário, o Executivo e o Legislativo. O Poder Legislativo era exercido por uma assembléia geral, composta de duas câmaras: a dos deputados, eletiva e temporária, e a dos senadores, cujos membros eram vitalícios e nomeados pelo Imperador, dentre integrantes de uma lista tríplice enviada pela Província. A eleição era indireta e censitária. O Poder Executivo era exercido pelos ministros de Estado, tendo como chefe o Imperador. O Poder Judiciário era independente, mas o Imperador, como chefe do Poder Moderador, podia suspender os juízes. O Poder Moderador podia destituir e nomear os ministros de Estado. Quanto ao legislativo, podia dissolver a Câmara dos Deputados, adiar a escolha e a convocação de senadores". In: ARAUJO, Luiz Alberto David; JÚNIOR, Vidal Serrano Nunes. Curso de direito constitucional. 7.ed. rev. e atual. São Paulo: Saraiva, 2003, p. 78. 
impossibilitar qualquer harmonia entre as manifestações da soberania e, inevitavelmente, impedia o amadurecimento de direitos fundamentais. Ainda, cabia ao Imperador, como Chefe do Poder Executivo, a nomeação de magistrados e o provimento dos demais empregos civis e políticos ${ }^{199}$.

Paulo Bonavides e Paes de Andrade comentam, acerca dessa realidade constitucional, a existência de grande distanciamento entre a Constituição formal (conteúdo) e a realidade das relações de poder (constituição material), situação decorrente, em grande parte, da ausência de limites à vontade e aos poderes do monarca ${ }^{200}$. É digno de nota, também, o grande paradoxo existente na Constituição de 1824, na medida em que consagrava uma série de direitos e, simultaneamente, convivia com a figura da escravidão, o que acabava por dividir a sociedade em dois grandes grupos, os senhores e os escravos, sendo o monarca o primeiro dos senhores ${ }^{201202}$.

Logo, a primeira Constituição brasileira, apesar de prodigiosa na consagração de direitos, não consagrou nenhum instrumento (garantia) hábil a conferir o acesso amplo e universal aos cargos públicos.

199 “Art. 102. O Imperador é o Chefe do Poder Executivo, e o exercita pelos seus Ministros de Estado.

São suas principaes attribuições

I. Convocar a nova Assembléa Geral ordinaria no dia tres de Junho do terceiro anno da Legislatura existente.

II. Nomear Bispos, e prover os Beneficios Ecclesiasticos.

III. Nomear Magistrados.

IV. Prover os mais Empregos Civis, e Politicos.

V. Nomear os Commandantes da Força de Terra, e Mar, e removel-os, quando assim o pedir o Serviço da Nação.

VI. Nomear Embaixadores, e mais Agentes Diplomaticos, e Commerciaes"

200 Segundo os autores "o Segundo Reinado institucionalizou, a seguir, um equilíbrio instável das duas organizações partidárias da monarquia - os liberais e os conservadores - cuja alternância no poder tinha por chave menos os preceitos e as regras da Constituição do que a vontade soberana do rei, titular do poder moderador. À margem desta, transcorria indiferentemente a vida política da Nação, volvida toda para adivinhar e sondar o querer imperial; este sim, supremo e decisivo em todos os lances de que pendia a formação ministerial e a sorte dos gabinetes. Colocado ao de uma realidade que praticamente a ignorava, pelo menos quando se tratava de reger os destinos do País, a Constituição outorgada e formal de 1824 se confrontava com outra lei maior sub-reptícia, vontade mais alta que a ofuscava por inteiro: o poder concreto e ativista do monarca. À sombra desse poder pessoal, que ignorava os cânones expressos do texto básico, medrou a originalíssima realidade de um parlamentarismo consentido, fora dos moldes constitucionais, criação do fato político, refratário a teorizações abstratas. O período constitucional do Império é portanto aquela quadra de nossa história em que o poder mais se apartou talvez da Constituição formal, e em que essa logrou o mais baixo grau de eficácia e presença na consciência de quantos, dirigindo a vida pública, guiavam o País para a solução das questões nacionais da época". In: BONAVIDES, Paulo e Paes de Andrade. História Constitucional do Brasil. 3.ed. Rio de Janeiro: Paz e Terra, 1991, pp. 6-7.

201 SILVA, Héber Americano. Direito constitucional: o homem e a sociedade o Estado constitucional brasileiro. $1^{\text {o }}$ volume, $2^{\text {a }}$ edição. Bauru: Jalovi, 1971, p. 75.

202 BONAVIDES, Paulo e Paes de Andrade. História Constitucional do Brasil. 3.ed. Rio de Janeiro: Paz e Terra, 1991, p.7. 
Com o passar dos anos, ocorreria a abolição da escravatura, modificando significativamente a economia agrária do país e abalando os alicerces da estrutura imperial. De fato, a crise na economia, como sempre, trouxe a crise política e o descontentamento da aristocracia rural, situação que, somada aos conflitos do império com o Exército e o Clero, criaram as condições necessárias à retirada do poder de seus detentores ${ }^{203}$.

Em razão do esgotamento do regime anterior, por diversas causas ${ }^{204}$, surge o texto constitucional de 1891, fruto de um golpe de Estado ou, segundo José Afonso da Silva, de uma simples passeata militar em uma bela manhã de $1889^{205}$, pela qual se extinguiu a monarquia, destituindo-se o imperador e proclamando-se a República Federativa $^{206}$, pautada na genialidade de Rui Barbosa e na confiança imitativa do modelo norte-americano. As influências da Constituição de 1891 derivaram da assunção do poder pelos liberais, sem qualquer aliança ou contrapeso absolutista de prerrogativas do Poder Moderador. Ocorre que a mentalidade liberal condutora do Estado, ao chegar ao Brasil, já não era tão preponderante e enfrentava questionamentos de ordem social ou por intervenção do Estado em algumas áreas da sociedade, o que deixava clara a existência de

\footnotetext{
${ }^{203}$ Sahid Maluf afiança a respeito desse interessante acontecimento da história brasileira que "a abolição da escravatura, repercutindo profundamente na economia agrária do País, abalou os alicerces da velha estrutura imperial. A crise econômica, como sempre, se fêz acompanhar da crise política. A aristocracia rural, descontente pela perda da propriedade escrava, passou a engrossar as fileiras do Partido Republicano. Os conflitos do governo imperial com o Exército e do Clero aumentaram a agitação geral. A tudo isso somava-se o problemas da sucessão de D. Pedro II, já velho e doente, sendo que, por sua morte, passaria a Coroa à princesa d. Isabel, casada com o Conde d'Eu (príncipe Gaston de Orlenas), de origem francesa. A imensa estima dos brasileiros pela figura veneranda do velho Imperador retardada, até então, o advento da República, porém, naquela época, nada mais poderia salvar a Monarquia agonizante. Aos 15 de novembro de 1889 as fôrças militares sob o comando do Marechal Deodoro da Fonseca, proclamaram a República". In: MALUF, Sahid. Curso de direito constitucional. 2. v. parte especial. 6.e.d. Sugestões Literárias S.A., 1972 . p. 11.

${ }^{204}$ MENDES, Gilmar Ferreira; COELHO, Inocêncio Mártires; BRANCO, Paulo Gustavo Gonet. Curso de direito constitucional São Paulo: Saraiva, 2007, p. 154.

205 “Tomba o Império sob o impacto das novas condições materiais, que possibilitam o domínio dessas velhas idéias com roupagens novas, e "um dia, por uma bela manhã, uma simples passeata militar" proclama a República Federativa por um decreto (o de n.1, de 15.11.1889, art. 1. o)". In: SILVA, José Afonso da. Curso de direito constitucional positivo. 13.ed. Malheiros Editores, 1997, p. 78.

206 “A 15 de novembro de 1889, dá-se no Brasil um golpe de Estado, pelo qual se põe fim à monarquia, destituindo-se por conseguinte o Imperador, proclamando-se uma República Federativa.

É de notar que este movimento não veio calcado em grandes movimentações populares ou em uma parte de opinião pública.

Na verdade tudo se cifrou a um movimento de tropas situadas no Rio de Janeiro, a que a nação limitou-se a assistir. Isto não quer dizer, contudo, que os ideais da República e da Federação, mais este último até do que o primeiro, não tivessem encontrado eco no País.

Foram diversos os movimentos que proclamaram a sua inspiração em uma dessas idéias, embora seja forçoso reconhecer que o ideário republicano federalista estivesse muito incipiente, sem contornos claramente definidos, pois o ideal predominante era o de emancipação política”. In: BASTOS, Celso Ribeiro. Curso de direito constitucional. 22. e.d. São Paulo: Saraiva, 2001, pp. 111-112.
} 
um abismo entre a Constituição escrita e a Constituição real ${ }^{207}$. Ela atribuiu ao Congresso Nacional a competência legislativa para criação e extinção de empregos públicos federais ${ }^{208}$ e, ao Presidente da República, a atribuição de prover os cargos civis e militares federais $^{209}$. Há, ainda, a previsão de amplo acesso aos cargos públicos por todos os brasileiros $^{210}$, bem como a declaração de que todos são iguais perante a lei ${ }^{211}$, sem que fosse estabelecido, contudo, um procedimento capaz de atender ao desejo constitucional.

Com a Constituição de 1934, inspirada sobremaneira na Constituição de Weimar (alemã, de 1919), bem como na do México, Espanha e Áustria ${ }^{212}$, o sistema de governo e a forma de Estado permaneceram inalterados; pouca modificação ocorreu também no que se refere à distribuição de competências ${ }^{213}$. Entre as singelas modificações, destacam-se os arts. 168 e 169, que trouxeram de maneira explícita a garantia do concurso público. Digo de maneira explícita, pois o fundamento teórico do concurso público está na proteção da igualdade, direito fundamental já consagrado em textos magnos anteriores. Vejamos a redação das normas em apreço:

${ }^{207}$ BONAVIDES, Paulo e Paes de Andrade. História Constitucional do Brasil. 3.ed. Rio de Janeiro: Paz e Terra, 1991, pp. 6-7.

208،“Art 34 - Compete privativamente ao Congresso Nacional:

$25^{\circ}$ ) criar e suprimir empregos públicos federais, fixar-lhes as atribuições, estipular-lhes os vencimentos;

${ }^{209}$ “'Art 48 - Compete privativamente ao Presidente da República: de capacidade especial que a lei estatuir, sendo, porém, vedadas as acumulações remuneradas.

Art 74 - As patentes, os postos e os cargos inamovíveis são garantidos em toda a sua plenitude.

Art 72 - A Constituição assegura a brasileiros e a estrangeiros residentes no País a inviolabilidade dos direitos concernentes à liberdade, à segurança individual e à propriedade, nos termos seguintes:

$\S 2^{\circ}$ - Todos são iguais perante a lei.

A República não admite privilégios de nascimento, desconhece foros de nobreza e extingue as ordens honoríficas existentes e todas as suas prerrogativas e regalias, bem como os títulos nobiliárquicos e de conselho.

Art 39 - Compete privativamente ao Poder Legislativo, com a sanção do Presidente da República:

6) criar e extinguir empregos públicos federais, fixar-lhes e alterar-lhes os vencimentos, sempre por lei especial;

$5^{\circ}$ ) prover os cargos civis e militares de caráter federal, salvas as restrições expressas na Constituição;

$11^{\circ}$ ) nomear os magistrados federais mediante proposta do Supremo Tribunal".

210 "Art 73 - Os cargos públicos civis ou militares são acessíveis a todos os brasileiros, observadas as condições de capacidade especial que a lei estatuir, sendo, porém, vedadas as acumulações remuneradas.

Art 74 - As patentes, os postos e os cargos inamovíveis são garantidos em toda a sua plenitude".

211 "Art 72 - A Constituição assegura a brasileiros e a estrangeiros residentes no País a inviolabilidade dos direitos concernentes à liberdade, à segurança individual e à propriedade, nos termos seguintes:

$\S 2^{\circ}$ - Todos são iguais perante a lei.

A República não admite privilégios de nascimento, desconhece foros de nobreza e extingue as ordens honoríficas existentes e todas as suas prerrogativas e regalias, bem como os títulos nobiliárquicos e de conselho.

${ }^{212}$ SILVA, Héber Americano. Direito constitucional: o homem e a sociedade o Estado constitucional brasileiro. $1^{\mathrm{o}}$ volume, $2^{\mathrm{a}}$ edição. Bauru: Jalovi, 1971, p. 79.

${ }^{213}$ BONAVIDES, Paulo e Paes de Andrade. História Constitucional do Brasil. 3.ed. Rio de Janeiro: Paz e Terra, 1991, p.9. 
“Art 168 - Os cargos públicos são acessíveis a todos os brasileiros, sem distinção de sexo ou estado civil, observadas as condições que a lei estatuir.

Art 169 - Os funcionários públicos, depois de dois anos, quando nomeados em virtude de concurso de provas, e, em geral, depois de dez anos de efetivo exercício, só poderão ser destituídos em virtude de sentença judiciária ou mediante processo administrativo, regulado por lei, e, no qual lhes será assegurada plena defesa”. (ênfase dada).

Ainda, o Texto Magno de 1934 inovou ao estabelecer em seu art. $170, \S 2^{\circ}$, que “a primeira investidura nos postos de carreira das repartições administrativas e nos demais que a lei determinar, efetuar-se-á depois de exame de sanidade e concurso de provas ou títulos".

A Constituição de 1937, por sua vez, serviu de fundamento político-jurídico para o regime que se instaurou no país, a pretexto de combater ameaças nazistas, fascistas e comunistas, importando o retrocesso de direitos e o agigantamento do Poder Executivo sobre os demais Poderes ${ }^{214}$, situação que se evidencia pelo teor do preâmbulo ${ }^{215}$ e do art.

\footnotetext{
${ }^{214}$ Preconiza José Afonso da Silva que "o país já se encontrava sob o impacto das ideologias que grassavam no mundo do após-guerra de 1918. Os partidos políticos assumiam posições em face da problemática ideológica vigente: surge um partido fascista, barulhento e virulento - a Ação Integralista Brasileira, cujo chefe, Plínio Salgado, como Mussolini e Hitler, se preparava para empolgar o poder; reorganiza-se o partido comunista, aguerrido e disciplinado, cujo chefe, Luís Carlos Prestes, também queria o poder. Getúlio Vargas, no poder, eleito que fora pela Assembléia Constituinte para o quadriênio constitucional, à maneira de Deodoro, como este, dissolve a Câmara e o Senado, revoga a Constituição de 1934, e promulga a Carta Constitucional de 10.11.37.

Fundamentou o golpe deitando a proclamação ao povo brasileiro, onde disse entre outras coisas: "Por outro lado, as novas formações partidárias, surgidas em todo o mundo, por sua própria natureza refratária aos processos democráticos, oferecem perigo imediato para as instituições, exigindo, de maneira urgente e proporcional à virulência dos antagonismos, o reforço do poder central". Assim se implantou a nova ordem denominada Estado Novo. Prometeu plebiscito para aprová-lo, mas nunca o convocou. Institui-se pura e simplesmente a ditadura". In: SILVA, José Afonso da. Curso de direito constitucional positivo. 13.ed. Malheiros Editores, 1997, pp. 83-84.

215 “O PRESIDENTE DA REPÚBLICA DOS ESTADOS UNIDOS DO BRASIL ,

ATENDENDO às legitimas aspirações do povo brasileiro à paz política e social, profundamente perturbada por conhecidos fatores de desordem, resultantes da crescente a gravação dos dissídios partidários, que, uma, notória propaganda demagógica procura desnaturar em luta de classes, e da extremação, de conflitos ideológicos, tendentes, pelo seu desenvolvimento natural, resolver-se em termos de violência, colocando a Nação sob a funesta iminência da guerra civil;

ATENDENDO ao estado de apreensão criado no País pela infiltração comunista, que se torna dia a dia mais extensa e mais profunda, exigindo remédios, de caráter radical e permanente;

ATENDENDO a que, sob as instituições anteriores, não dispunha, o Estado de meios normais de preservação e de defesa da paz, da segurança e do bem-estar do povo;

Com o apoio das forças armadas e cedendo às inspirações da opinião nacional, umas e outras justificadamente apreensivas diante dos perigos que ameaçam a nossa unidade e da rapidez com que se vem processando a decomposição das nossas instituições civis e políticas;

Resolve assegurar à Nação a sua unidade, o respeito à sua honra e à sua independência, e ao povo brasileiro, sob um regime de paz política e social, as condições necessárias à sua segurança, ao seu bem-estar e à sua prosperidade, decretando a seguinte Constituição, que se cumprirá desde hoje em todo o Pais”.
} 
$11^{216}$ do texto constitucional. Mesmo assim, foi mantida a exigência de concurso público para a primeira investidura em cargos públicos de carreira ${ }^{217}$.

A Lei Maior de 1946 restabeleceu a independência e a harmonia entre os Poderes $^{218}$, mantendo as demais disposições acerca do acesso a cargos públicos 219220221 222. Gilmar Ferreira Mendes observa, sem embargo do inegável conteúdo democrático e moralizador do avanço constitucional verificado até 1946, que as normas que restringiam a aplicabilidade da exigência de concurso aos cargos de carreira e a outros que a lei determinasse acabavam por retirar a plena eficácia do instituto em referência, porquanto possibilitavam a criação de cargos isolados ou a transformação de cargos de carreira em cargos isolados 223 .

Narrado histórico constitucional revela que o concurso público nem sempre foi exigência universal ou requisito para o exercício de qualquer posto público, pois dele se excepcionavam empregos públicos ${ }^{224}$, funções públicas e cargos em comissão, bem como

216 “Art 11 - A lei, quando de iniciativa do Parlamento, limitar-se-á a regular, de modo geral, dispondo apenas sobre a substância e os princípios, a matéria que constitui o seu objeto. O Poder Executivo expedirá os regulamentos, complementares".

217 "Art 156 - O Poder Legislativo organizará o Estatuto dos Funcionários Públicos, obedecendo aos seguintes preceitos desde já em vigor:

a) o quadro dos funcionários públicos compreenderá todos os que exerçam cargos públicos criados em lei, seja qual for a forma de pagamento;

b) a primeira investidura nos cargos de carreira far-se-á mediante concurso de provas ou de títulos;

c) os funcionários públicos, depois de dois anos, quando nomeados em virtude de concurso de provas, e, em todos os casos, depois de dez anos de exercício, só poderão ser exonerados em virtude de sentença judiciária ou mediante processo administrativo, em que sejam ouvidos e possam defender-se".

218 “Art $7^{\circ}$ - O Governo federal não intervirá nos Estados salvo para:

VII - assegurar a observância dos seguintes princípios:

b) independência e harmonia dos Poderes".

219 “Art 65 - Compete ao Congresso Nacional, com a sanção do Presidente da República:

IV - criar e extinguir cargos públicos e fixar-lhes os vencimentos, sempre por lei especial”.

220 “Art 87 - Compete privativamente ao Presidente da República:

V - prover, na forma da lei e com as ressalvas estatuídas por esta Constituição, os cargos públicos federais".

221 "Art 141 - A Constituição assegura aos brasileiros e aos estrangeiros residentes no País a inviolabilidade dos direitos concernentes à vida, à liberdade, a segurança individual e à propriedade, nos termos seguintes:

$\S 1^{\circ}$ Todos são iguais perante a lei”.

222 "Art 184 - Os cargos públicos são acessíveis a todos os brasileiros, observados os requisitos que a lei estabelecer.

Art 185 - É vedada a acumulação de quaisquer cargos, exceto, a prevista no art. 96, n $^{\circ} \mathrm{I}$, e a de dois cargos de magistério ou a de um destes com outro técnico ou científico, contanto que haja correlação de matérias e compatibilidade de, horário.

Art 186 - A primeira investidura em cargo de carreira e em outros que a lei determinar efetuar-se-á mediante concurso, precedendo inspeção de saúde".

${ }^{223}$ MENDES, Gilmar Ferreira. O princípio do concurso publico na jurisprudência do Supremo Tribunal Federal: alguns aspectos. Revista de Informacao Legislativa. Brasilia. v.25. n.100. p.165. out./dez. 1988.

224 "Constituição de 1969, art. 99, $\$ 2^{\circ}$ A proibição de acumulação estende-se a cargos, funções ou empregos em autarquias, emprêsas públicas e sociedade de economia mista”. 
o acesso a outros cargos, uma vez que as normas estabeleciam o procedimento igualitário apenas para a ocupação do primeiro cargo.

A Constituição de 1967 provocou a ampliação da proteção à igualdade, ao exigir a prévia passagem por concurso público para o acesso a qualquer cargo público, e não apenas para o primeiro provimento ${ }^{225}$. Contudo, em mais um exemplo dos avanços e dos retrocessos da política pátria, a Constituição de 1969 trouxe de volta a sistemática da necessidade de concurso apenas para a ocupação do primeiro cargo público ${ }^{226}$. O Texto Maior continha, também, a previsão de admissão de servidores temporários para o atendimento de serviços temporários ou para o exercício de funções de natureza técnica especializada $^{227}$.

A CR de 1988, com os olhos voltados à igualdade, veio estabelecer que o acesso aos postos públicos, isto é, aos cargos ou empregos públicos, ressalvados casos excepcionais expressamente mencionados, ocorrerá por meio da aprovação em concurso público (art. 37, I e II). Nessa linha, a proteção à igualdade acaba por refletir, no campo das relações de trabalho, de modo a tornar universal o acesso aos postos públicos e a ampliar as possibilidades de ocupação de empregos dignos. Desse modo, o acesso igualitário, por meio do concurso público, corrobora a valorização do trabalho humano ${ }^{228}$.

Jessé Torres Pereira Junior destaca que a Constituição de 1988 inovou em relação à Carta Política anterior, ao não distinguir a que investidura há de se aplicar a exigência de

\footnotetext{
225“Art 95 - Os cargos públicos são acessíveis a todos os brasileiros, preenchidos os requisitos que a lei estabelecer.

$\S 1^{\circ}$ - A nomeação para cargo público exige aprovação prévia em concurso público de provas ou de provas e títulos.

$\S 2^{\circ}$ - Prescinde de concurso a nomeação para cargos em comissão, declarados em lei, de livre nomeação e exoneração".

226 "Art. 97. Os cargos públicos serão acessíveis a todos os brasileiros que preencham os requisitos estabelecidos em lei.

$\S 1^{\circ}$ A primeira investidura em cargo público dependerá de aprovação prévia, em concurso público de provas e títulos, salvo os casos indicados em lei.

$\S 2^{\circ}$ Prescindirá de concurso a nomeação para cargos em comissão, declarados em lei, de livre nomeação e exoneração".

227 "Art. 106. O regime jurídico dos servidores admitidos em serviços de caráter temporário ou contratados para funções de natureza técnica especializada será estabelecido em lei especial".

${ }^{228}$ A importância do trabalho na Constituição de 1988 é destacada por Pinto Ferreira com as seguintes palavras "o trabalho é a fonte principal da riqueza das nações. O trabalho ainda tem em grande parte um sentido humilhante e triste no País, num mundo repleto de injustiças, de contrastes chocantes, envolto numa onda de pessimismo. A vida perde sua beleza sob esta perspectiva de fome, de miséria e de morte, com as condições deploráveis de trabalho.

"A valorização do trabalho, permitindo uma justa remuneração, necessária às necessidades do trabalhador e de sua família, permite também uma ordem social mais justa, evitando abusos e opressões”. In: FERREIRA, Pinto. Comentários à Constituição brasileira. $6^{\circ}$ vol. São Paulo: Saraiva, 1994, p. 242.
} 
prévia aprovação em concurso, o que levou o STF a assentar que a maioria dos modos secundários de provimento de cargo ou emprego (acesso, progresso, transposição) tornaram-se incompatíveis com o novo regime, pois qualquer provimento passou a depender da competição seletiva pública, excetuada a promoção, desde que se trate de cargos ou empregos organizados em carreira, hipóteses em que o ingresso mediante concurso é exigível apenas para o primeiro acesso ${ }^{229}$.

De igual modo, Alexandre de Moraes registra que a investidura em cargos ou empregos públicos depende de prévia aprovação em concurso público, inexistindo autorização para a edição de lei que, mediante o agrupamento de carreiras, opere transformações em cargos, possibilitando que os ocupantes de cargos originários sejam investidos nos novos cargos, de carreira distinta daquela na qual ingressaram na Administração, sem concurso público ${ }^{230}$.

A transição de modos de acesso a cargos e empregos públicos, ainda hoje, não se mostra plena e efetiva, devido ao histórico constitucional e aos ranços das práticas de apadrinhamento nas relações de trabalho no âmbito da Administração Pública, além da inicial controvérsia, hoje superada, acerca da necessidade do concurso público para as contratações de pessoal das empresas estatais, ou seja, das sociedades de economia mista e das empresas públicas.

Os contrários a essa exigência para o estabelecimento válido da relação de emprego com as empresas estatais argumentavam que a previsão do II do art. 37 impunhase à investidura em cargo ou emprego público e, para tais defensores, não haveria emprego público nas sociedades de economia mista e nas empresas públicas, por serem regidas pelo regime jurídico próprio das empresas privadas, inclusive quanto às obrigações trabalhistas ${ }^{231}$.

Maria Sylvia Zanella Di Pietro, já em 1989, mostrava-se favorável à aplicação da exigência de concurso público às empresas estatais, ao argumento de que a adoção do

\footnotetext{
${ }^{229}$ PEREIRA JUNIOR, Jesse Torres. Repercussões da emenda constitucional 19 sobre os concursos para provimento de cargos e empregos públicos. Revista de Direito Constitucional e Internacional. São Paulo. v.8. n.32. jul./set. 2000. p.210.

${ }^{230}$ MORAES, Alexandre. Constituição do Brasil interpretada e legislação constitucional. 2. ed. São Paulo: Atlas, 2003, p. 833.

${ }^{231}$ ROCHA, João Luiz Coelho da. A administração estatal indireta e o concurso público. Revista de Direito Mercantil, Industrial, Econômico e Financeiro. São Paulo. v.31. n.87. p.17-20. jul./set. 1992, p. 19.
} 
modelo de empresa privada não significa, ipso facto, o afastamento dos princípios gerais da Administração Pública, pois institutos de Direito Privado e de Direito Administrativo podem conviver harmonicamente, por exemplo, convivem o contrato de compra e venda e a licitação e, ademais, fosse vontade do Poder Constituinte ${ }^{232}$ afastar a ampla possibilidade de acesso aos empregos públicos, teria o feito de maneira expressa ${ }^{233}$.

A questão restou pacificada desde a decisão do STF proferida nos autos do Mandado de Segurança n ${ }^{\circ}$ 21.322-1, Ministro-Relator Paulo Brossard, publicado no Diário Oficial de $23.04 .93^{234}$, julgamento a partir do qual se tornou incontestável a necessidade de prévia aprovação em concurso para a valida ocupação de empregos em empresas estatais $^{235}$, entendimento que restou acolhido pelo TST, desde 23.05.2013, no julgamento do processo TST-E-ED-RR-4800-05.2007.5.10.0008 ${ }^{236}$.

${ }^{232}$ Assenta Michel Temer que Poder Constituinte "é a manifestação soberana de vontade de um ou alguns indivíduos capaz de fazer nascer um núcleo social”. In: TEMER, Michel. Elementos de direito constitucional. 20. ed. Malheiros Editores, p. 29.

${ }^{233}$ DI PIETRO, Maria Sylvia Zanella. Concurso público na administração indireta. Revista de Direito Publico. Sao Paulo. v.23. n.93. p.129-32. jan./mar. 1990. p. 132.

234 "EMENTA: CARGOS e EMPREGOS PUBLICOS. ADMINISTRAÇÃO PÚBLICA DIRETA, INDIRETA e FUNDACIONAL. ACESSIBILIDADE. CONCURSO PÚBLICO. A acessibilidade aos cargos públicos a todos os brasileiros, nos termos da Lei e mediante concurso público e princípio constitucional explicito, desde 1934, art. 168. Embora cronicamente sofismado, mercê de expedientes destinados a iludir a regra, não só foi reafirmado pela Constituição, como ampliado, para alcançar os empregos públicos, art. 37, I e II. Pela vigente ordem constitucional, em regra, o acesso aos empregos públicos opera-se mediante concurso público, que pode não ser de igual conteúdo, mas há de ser público. As autarquias, empresas publicas ou sociedades de economia mista estão sujeitas a regra, que envolve a administração direta, indireta ou fundacional, de qualquer dos poderes da União, dos Estados, do Distrito Federal e dos Municípios. Sociedade de economia mista destinada a explorar atividade econômica esta igualmente sujeita a esse princípio, que não colide com o expresso no art. 173, PAR. 1.. Exceções ao princípio, se existem, estão na própria Constituição. DJ 23-04-1993 PP-06921”. In: BRASIL. Supremo Tribunal Federal. Acórdão no Mandado de Segurança n. 21.322-1/DF. Relator: BROSSARD, Paulo. Publicado no DJ de 23.04.1993. Disponível em <http://redir.stf.jus.br/paginadorpub/paginador.jsp?docTP=AC\&docID=85492>. Acessado em 30.06.2013.

235 “A administração indireta tentou por diversas formas ser poupada dessa exigência, mas não conseguiu, pois também para sua situação se aplicam as exigências do art. 37 da Constituição da República de 1988”. In: SILVA, Homero Batista Mateus da. Curso de direito do trabalho aplicado, vol. 6:contrato de trabalho. Rio de Janeiro: Elsevier, 2009, p. 26.

236 "Empresa pública e sociedade de economia mista. Admissão sem prévia aprovação em concurso público após a promulgação da Constituição Federal de 1988. Decisão do STF no MS no 21322/DF. Marco para declaração de nulidade da contratação. Inaplicabilidade da Súmula n 363 do TST.

A decisão proferida pelo STF no MS no 21322/DF, publicada em 23.4.1993, deve ser tomada como marco para a declaração de nulidade dos contratos de trabalho firmados com empresa pública ou sociedade de economia mista sem prévia aprovação em concurso público, após a promulgação da Constituição Federal de 1988, de modo que o disposto no art. 37, § 2º da CF apenas alcança os contratos de trabalho celebrados após essa data. Com esse entendimento, a SBDI-I, em sua composição plena, decidiu, à unanimidade, conhecer dos embargos, por divergência jurisprudencial, e, no mérito, dar-lhes provimento para, afastando a incidência da Súmula $n^{\circ} 363$ do TST e a nulidade do contrato de trabalho firmado com a Radiobrás, em 07.01.93, sem concurso público, restabelecer a decisão do Regional, determinando o retorno dos autos à Turma de origem para apreciar os demais temas recursais como entender de direito". In: BRASIL. Tribunal Superior do 
Repare-se que a celeuma em destaque teve origem na aparente controvérsia existente entre o art. 37, II, e o art. 173, $\S 1^{\circ}$, ambos da CR, em suas redações anteriores à Emenda $n^{\circ} 19 / 1998$. O exercício do Poder Constituído ${ }^{237}$ teve o condão de esclarecer que as empresas públicas e as sociedades de economia mista não se submetem, unicamente, ao mesmo regime das pessoas jurídicas de Direito Privado, mas, também, se vinculam aos preceitos da Administração Pública.

Interessa notar que o atual Texto Maior, em estrutura diversa da adotada pela Constituição anterior, consagra a exigência do concurso público no capítulo próprio da Administração Pública, o que sugere a ampla abrangência de seus rigores para acesso aos cargos e empregos públicos. Esclareça-se, por necessário, que as normas outrora vigentes dispunham sobre concurso público apenas nos capítulos que se reservavam às funções públicas, o que acabava por não estender à garantia da igualdade no acesso às empresas estatais.

Atualmente, encontramos como exceções à exigência da prévia aprovação em concurso público as hipóteses normatizadas no art. 37, II, in fine $e^{238}$, no art. 73, no art. 94,

Trabalho. Acórdão no processo TST-E-ED-RR-4800-05.2007.5.10.0008. Relator: VEIGA, Aloysio Corrêa da Disponível

em:

<https://aplicacao5.tst.jus.br/consultaProcessual/decisaoForm.do?numInt=430500\&anoInt=2008\&codOrgaoJ udic $=53 \&$ anoPauta $=2013 \&$ numPauta $=15 \&$ tipSessao $=0>$. Acessado em 28.12.2013.

${ }^{237}$ A atual redação do art. 173 da CF: "Art. 173. Ressalvados os casos previstos nesta Constituição, a exploração direta de atividade econômica pelo Estado só será permitida quando necessária aos imperativos da segurança nacional ou a relevante interesse coletivo, conforme definidos em lei.

$\S 1^{\circ}$ A lei estabelecerá o estatuto jurídico da empresa pública, da sociedade de economia mista e de suas subsidiárias que explorem atividade econômica de produção ou comercialização de bens ou de prestação de serviços, dispondo sobre: (Redação dada pela Emenda Constitucional $\mathrm{n}^{\circ}$ 19, de 1998)

I - sua função social e formas de fiscalização pelo Estado e pela sociedade; (Incluído pela Emenda Constitucional $\mathrm{n}^{\circ} 19$, de 1998)

II - a sujeição ao regime jurídico próprio das empresas privadas, inclusive quanto aos direitos e obrigações civis, comerciais, trabalhistas e tributários; (Incluído pela Emenda Constitucional no 19, de 1998)

III - licitação e contratação de obras, serviços, compras e alienações, observados os princípios da administração pública; (Incluído pela Emenda Constitucional nº 19, de 1998)

IV - a constituição e o funcionamento dos conselhos de administração e fiscal, com a participação de acionistas minoritários; (Incluído pela Emenda Constitucional n ${ }^{\circ} 19$, de 1998)

V - os mandatos, a avaliação de desempenho e a responsabilidade dos administradores.(Incluído pela Emenda Constitucional no 19, de 1998)".

238 "Art. 37. A administração pública direta e indireta de qualquer dos Poderes da União, dos Estados, do Distrito Federal e dos Municípios obedecerá aos princípios de legalidade, impessoalidade, moralidade, publicidade e eficiência e, também, ao seguinte: (Redação dada pela Emenda Constitucional no 19, de 1998)

I - os cargos, empregos e funções públicas são acessíveis aos brasileiros que preencham os requisitos estabelecidos em lei, assim como aos estrangeiros, na forma da lei; (Redação dada pela Emenda Constitucional $\mathrm{n}^{\circ} 19$, de 1998)

II - a investidura em cargo ou emprego público depende de aprovação prévia em concurso público de provas ou de provas e títulos, de acordo com a natureza e a complexidade do cargo ou emprego, na forma prevista em lei, ressalvadas as nomeações para cargo em comissão declarado em lei de livre nomeação e exoneração; (Redação dada pela Emenda Constitucional n ${ }^{\circ} 19$, de 1998)". 
no art. $143^{239}$, no art. $198, \S 4^{0240} 241$, todos da Constituição, no art. $19^{242}$ e no art. 53 , I, do Ato das Disposições Constitucionais Transitórias - $\mathrm{ADCT}^{243}$. Encontramos entre as hipóteses os cargos em comissão, os casos dos agentes comunitários de saúde e os militares atuantes na II Guerra Mundial. As duas primeiras hipóteses referem-se a ocupações transitórias de postos; já a segunda, cuida de situação em que o militar combatente na guerra, independentemente de concurso público, pode ser aproveitado no serviço público com estabilidade.

Encontramos nos ADCT, ainda, regras de transição entre os regimes constitucionais de 1969 e 1988, no que se refere à contratação sem concurso público. No art. 19 dos ADCT, o Poder Constituinte originário normatizou que os servidores públicos civis da União, dos Estados, do Distrito Federal e dos Municípios, em serviço na data da

${ }^{239}$ A respeito desse artigo Fábio Moreira de Almeida afirma que “...não há que falar em ingresso voluntário nas Forças Armadas, mediante concurso público, nos casos de anormalidade, ou seja, conflitos armados ou sua iminência, convocações de emergência, calamidades públicas etc. e nos casos de prestação de serviço militar obrigatório. Em todas essas situações não é viável a realização de concurso público, isto porque o serviço militar, de acordo com o art. $1^{\circ}$, da Lei $4.375 / 64$ e art. $2^{\circ}$, I, da Lei 11.631/07, está diretamente relacionado à formação de determinado contingente destinado ao atendimento das necessidades das Forças Armadas quando do advento de eventual execução da mobilização nacional ou outra necessidade emergencial prevista em lei”. In: ALMEIDA, Fábio Moreira de. O ingresso voluntário nas forças armadas e o concurso público. Revista da Escola da Magistratura Regional Federal da $2^{a}$ Região. Rio de Janeiro. v.15. n.1. p.163-74. ago. 2011, p. 168.

240 "Art. 198. As ações e serviços públicos de saúde integram uma rede regionalizada e hierarquizada e constituem um sistema único, organizado de acordo com as seguintes diretrizes:

$\S 4^{\circ}$ Os gestores locais do sistema único de saúde poderão admitir agentes comunitários de saúde e agentes de combate às endemias por meio de processo seletivo público, de acordo com a natureza e complexidade de suas atribuições e requisitos específicos para sua atuação. Incluído pela Emenda Constitucional $\mathrm{n}^{\circ}$ 51, de 2006)".

${ }^{241}$ A estipulação de processo seletivo público no lugar de concurso público não passou isenta de observações pelos estudiosos, segundo Vanice Lírio do Valle "grosso modo, a referida disposição constitucional elege as categorias beneficiárias do novo regime de vinculação de pessoal que proporá nos parágrafos subseqüentes agentes comunitários de saúde e agentes de controle de endemias -; elege ainda o mecanismo de seleção desses profissionais - processo seletivo público - e finalmente, aponta vetores que subordinarão a esse mesmo processo seletivo, a saber, concordância prática com a natureza e complexidade de suas atribuições e requisitos específicos para sua atuação" In: VALLE, Vanice Lírio do. Emenda Constitucional n.51/06, processo seletivo público e novos regimes de vinculação de pessoal ao poder público: uma boa idéia para quem? A \& C: Revista de Direito Administrativo e Constitucional. Belo Horizonte. v.6. n.24. p.52. abr.jun. 2006.

${ }^{242}$ Esclarece Celso Antônio Bandeira de Mello "deveras, o $§ 1^{\circ}$ do art. 19 das Disposições Transitórias, com meridiana clareza, deixou manifesto que inadmitia a possibilidade de que aos sobredito servidores, sob pretexto de estabilização, fosse conferida, adicionalmente, a vantagem de ingressarem em cargos públicos. Vedou que, sub-repticiamente, sub color de ilação ou de presumível conseqüência da estabilidade, viessem, sem concurso, a ser transformados no sucedâneo de funcionários públicos, isto é, em agentes sujeitos ao regime próprio destes (sob tal designação ou outras que se lhes atribuísse) e incluídos nos planos e sistemas de carreira próprios dos que ascenderam a cargos públicos por concurso". In: MELLO, Celso Antônio Bandeira de. "Regime único" dos servidores federais e o dever de concurso publico. Revista da Procuradoria Geral do Estado de São Paulo. n.35. p.11-23. jun. 1991, p. 18.

243 "Art. 53. Ao ex-combatente que tenha efetivamente participado de operações bélicas durante a Segunda Guerra Mundial, nos termos da Lei $\mathrm{n}^{\circ}$ 5.315, de 12 de setembro de 1967, serão assegurados os seguintes direitos:

I - aproveitamento no serviço público, sem a exigência de concurso, com estabilidade;". 
promulgação da vigente Constituição, há pelo menos cinco anos continuados e que não tenham sido admitidos por concurso público, são considerados estáveis no serviço público $^{244}$. Lembre-se, na esteira de dizeres registrados em páginas anteriores, de que a Constituição de 1969 previa o concurso público como via de acesso aos cargos públicos, ao menos para o primeiro acesso, de modo que, mesmo sob o regime militar, as contratações sem a observância do regime constitucional eram nulas. Ao que parece, contudo, a disposição transitória em relevo tornou constitucional uma prática que violou as normas de maior hierarquia até 4 de outubro de 1988, pois transformou o nulo em válido, o que é tolerável juridicamente em razão das conhecidas características de do Poder Constituinte Originário.

Nas relações de emprego com a Administração Pública, podem existir diversas nulidades, ou seja, múltiplos vícios atrelados à validade do negócio jurídico. A de maior proeminência, não só no presente trabalho, mas, também, na prática administrativa, pois envolve a garantia de acesso igualitário aos postos públicos, é a ausência de concurso público. Assim, embora a prévia aprovação em concurso não constitua requisito essencial à configuração da relação de emprego, o é para a manutenção dessa relação ou para a sua qualificação como válida.

Logo, não é demasiado visualizar no concurso público uma garantia, sem a qual o princípio da igualdade não seria observado, como diretriz universal, para a ocupação dos cargos ou empregos públicos.

\section{Ausência de concurso público. Posição do TST e seus fundamentos.}

A clareza das normas que impõem a observância do concurso público para o acesso à generalidade de empregos públicos desde a última Constituição, apesar das

\footnotetext{
244 “Art. 19. Os servidores públicos civis da União, dos Estados, do Distrito Federal e dos Municípios, da administração direta, autárquica e das fundações públicas, em exercício na data da promulgação da Constituição, há pelo menos cinco anos continuados, e que não tenham sido admitidos na forma regulada no art. 37, da Constituição, são considerados estáveis no serviço público.

$\S 1^{\circ}$ - O tempo de serviço dos servidores referidos neste artigo será contado como título quando se submeterem a concurso para fins de efetivação, na forma da lei.

$\S 2^{\circ}$ - O disposto neste artigo não se aplica aos ocupantes de cargos, funções e empregos de confiança ou em comissão, nem aos que a lei declare de livre exoneração, cujo tempo de serviço não será computado para os fins do "caput" deste artigo, exceto se se tratar de servidor.

$\S 3^{\circ}$ - O disposto neste artigo não se aplica aos professores de nível superior, nos termos da lei”.
} 
dificuldades de aceitação ou de compreensão que imperaram nos primeiro cinco anos de vigência do Documento Maior, fez com que doutrina e jurisprudência enfrentassem o encargo de dar uma resposta satisfatória à contratação de empregados sem a prévia observância do concurso público ${ }^{245}$.

Os tribunais superiores, Supremo Tribunal Federal, Superior Tribunal de Justiça, Tribunal Superior do Trabalho e Tribunal Superior Eleitoral ${ }^{246}$, possuem a missão constitucional de uniformizar a interpretação do Direito, bem como garantir a supremacia da ordem jurídica. Ao TST cabe, sem prejuízo da previsão geral de guarida da Constituição, a uniformização e a tutela do direito infraconstitucional que verse sobre relações de trabalho em sentido lato. A Lei Maior, em seu art. 111-A, § $1^{\circ}$, incumbiu ao legislador constituído a missão de regular a competência do TST, o que foi atendido pela Lei ${ }^{\circ}$ 7.701, de 21 de dezembro de 1988.

Segundo o diploma normativo em destaque ${ }^{247}$, o TST será divido em Turmas e Seções. Com espeque no art. 96, inciso I, alínea $a$, da $\mathrm{CR}^{248}$, o TST editou seu Regimento Interno $^{249}$, que, entre outros assuntos, disciplina a edição de Súmulas e Orientações Jurisprudenciais. Em apertada síntese, as Súmulas e Orientações Jurisprudenciais representam ou externam a posição pacificada do TST a respeito de determinada matéria sujeita à sua competência. Porém, para se descobrirem as razões que levaram o órgão colegiado a adotar determinada postura, mostra-se de maior valor científico o estudo dos precedentes que subsidiam o entendimento consolidado.

Como é sabido, apenas com a Constituição de 1988, a prévia aprovação em concurso público se tornou obrigatória para a ocupação de cargos e empregos públicos. Dessa forma, sob os auspícios de normas magnas anteriores, o TST admitia e admite a

\footnotetext{
245 “Com o advento da Constituição da República de 1988, o colendo Tribunal Superior do Trabalho passou a enfrentar o encargo de dar uma resposta satisfatória a uma prática reiterada da Administração Pública: a contratação de empregados sem a prévia observância do necessário e salutar concurso público (artigo 37, II, da Constituição da República)". In: CRUZ, Alexandre Corrêa da. Os efeitos da contratação sem concurso pelo ente público: da impropriedade do enunciado 363 do TST. Disponível em: <http://www.femargs.com.br/revista03_cruz.html>. Acesso em 14.12.2012.

246 “Título IV, capítulo III, da Constituição da República”.

247 “Art. $1^{\circ}$ O Tribunal Superior do Trabalho, nos processos de sua competência, será dividido em Turmas e seções especializadas para a conciliação e julgamento de dissídios coletivos de natureza econômica ou jurídica e de dissídios individuais, respeitada a paridade de representação classista."

248 “Art. 96. Compete privativamente: I - aos tribunais: a) eleger seus órgãos diretivos e elaborar seus regimentos internos, com observância das normas de processo e das garantias processuais das partes, dispondo sobre a competência e o funcionamento dos respectivos órgãos jurisdicionais e administrativos."

${ }_{249}$ Aprovado pela Resolução Administrativa n ${ }^{\circ}$ 1295/1998. Publicada no Diário da Justiça da União de 09/05/2008, páginas 20 a 30 .
} 
formação de vínculo de emprego com a Administração Pública e, de igual sorte, a ampla concessão de direitos, desde que presentes os requisitos mencionados pelos arts. $2^{\circ}$ e $3^{\circ}$ da - CLT, elementos de existência, sem a exigência de nenhuma solenidade 250251.

Por outro lado, amparado nos ditames da atual CR sobre concurso público, o TST editou a Súmula 363, de seguinte conteúdo:

\begin{abstract}
"SUM-363 CONTRATO NULO. EFEITOS (nova redação) - Res. 121/2003, DJ 19, 20 e 21.11.2003. A contratação de servidor público, após a CF/1988, sem prévia aprovação em concurso público, encontra óbice no respectivo art. 37 , II e $\S 2^{\circ}$, somente lhe conferindo direito ao pagamento da contraprestação pactuada, em relação ao número de horas trabalhadas, respeitado o valor da hora do salário mínimo, e dos valores referentes aos depósitos do FGTS".
\end{abstract}

Veja-se que a atual redação da Súmula 363 do TST possui como precedentes mais recentes os julgados exarados nos processos $n^{\circ}$ TST-RXOFROAR-71842/2002-900-11$00.0^{252}$, TST-RXOFROAR-47/2002-000-17-00.0 $0^{253}$, TST-RXOFAR-91038/2003-900-11$00.8^{254}$, TST-E-RR-672.320/00.4 ${ }^{255}$, os três primeiros de relatoria do Ministro Barros Levenhagem e o último, de relatoria do Ministro João Orestes Dalazen.

$\mathrm{Na}$ esteira do teor dos precedentes, pode-se verificar que para o TST a contratação

250، OJ-SDI1-321. VÍNCULO EMPREGATÍCIO COM A ADMINISTRAÇÃO PÚBLICA. PERÍODO ANTERIOR À CF/1988 (nova redação) - DJ 20.04.2005. Salvo os casos de trabalho temporário e de serviço de vigilância, previstos nas Leis $\mathrm{n}^{\circ} \mathrm{s} 6.019$, de 03.01.1974, e 7.102, de 20.06.1983, é ilegal a contratação de trabalhadores por empresa interposta, formando-se o vínculo empregatício diretamente com o tomador dos serviços, inclusive ente público, em relação ao período anterior à vigência da CF/1988".

251 "OJ-SDI1-366. ESTAGIÁRIO. DESVIRTUAMENTO DO CONTRATO DE ESTÁGIO. RECONHECIMENTO DO VÍNCULO EMPREGATÍCIO COM A ADMINISTRAÇÃO PÚBLICA DIRETA ou INDIRETA. PERÍODO POSTERIOR À CONSTITUIÇÃO FEDERAL DE 1988. $\begin{array}{llcccc}\text { IMPOSSIBILIDADE } & \text { (DJ } & \mathbf{2 0} & \mathbf{2 1} & \mathrm{e} & \mathbf{2 3 . 0 5 . 2 0 0 8} \text { ) }\end{array}$ Ainda que desvirtuada a finalidade do contrato de estágio celebrado na vigência da Constituição Federal de 1988, é inviável o reconhecimento do vínculo empregatício com ente da Administração Pública direta ou indireta, por força do art. 37, II, da CF/1988, bem como o deferimento de indenização pecuniária, exceto em relação às parcelas previstas na Súmula n 363 do TST, se requeridas".

${ }^{252}$ BRASIL. Tribunal Superior do Trabalho. Acórdão no processo TST-RXOFROAR-71842/2002-900-1100.0. Relator: LEVENHAGEN, Antônio José de Barros. Disponível em: $<$ https://aplicacao5.tst.jus.br/consultaProcessual/consultaTst.do?conscsjt=\&numeroTst=71842\&anoTst=2002 \&varaTst $=900 \&$ trtTst $=11 \&$ seqTst $=00 \&$ consulta $=$ Consultar $>$. Acessado em 28.12.2013.

${ }^{253}$ BRASIL. Tribunal Superior do Trabalho. Acórdão no processo TST-RXOFROAR-47/2002-000-17-00.0. Relator: LEVENHAGEN, Antônio José de Barros. Disponível em: $<$ https://aplicacao5.tst.jus.br/consultaProcessual/consultaTst.do?conscsjt=\&numeroTst=47\&anoTst=2002\&v araTst $=000 \& \operatorname{trtTst}=17 \&$ seqTst $=00 \&$ consulta $=$ Consultar $>$. Acessado em 28.12.2013.

${ }^{254}$ BRASIL. Tribunal Superior do Trabalho. Acórdão no processo TST-RXOFAR-91038/2003-900-11-00.8. Relator: LEVENHAGEN, Antônio José de Barros. Disponível em: <https://aplicacao5.tst.jus.br/consultaProcessual/consultaTst.do?conscsjt=\&numeroTst=91038\&anoTst=2003 $\&$ varaTst $=900 \& \operatorname{trt} \mathrm{Tst}=\&$ seqTst $=\&$ consulta $=$ Consultar $>$. Acessado em 28.12.2013.

${ }^{255}$ BRASIL. Tribunal Superior do Trabalho. Acórdão no processo TST-E-RR-672.320/00.4. Relator: DALAZEN, João Oreste. Disponível em: <https://aplicacao5.tst.jus.br/consultaProcessual/consultaTst.do?conscsjt=\&numeroTst=672320\&anoTst=200 $0 \&$ varaTst $=\& \operatorname{trt} T s t=\&$ seqTst $=\&$ consulta $=$ Consultar $>$. Acessado em 28.12.2013. 
de servidor público após a Constituição de 1988, sem a prévia aprovação em concurso público, encontra óbice no art. 37 , II e $\S 2^{\circ}$, sendo nula de pleno direito e, portanto, a decisão que o declara possui efeitos ex tunc, de sorte a não surtir nenhum efeito trabalhista a relação jurídica estabelecida. A Corte Trabalhista firmou a tese de que a nulidade é absoluta, com implícita remissão ao artigo 145, inciso IV ${ }^{256}$, do Código Civil de 1916, pelo qual é nulo o ato jurídico quando for preterida alguma solenidade que a lei considere essencial para a sua validade ${ }^{257}$.

Sensibilizado, no entanto, com o fato material de o trabalho ter sido prestado, acabou o TST por mitigar os efeitos da nulidade absoluta, a fim de reconhecer direito ao pagamento da contraprestação pactuada, em relação ao número de horas trabalhadas, o que abrange horas extras sem o respectivo adicional e diferenças em relação ao salário mínimo legal, bem como aos depósitos do FGTS, por força do art. 19-A ${ }^{258}$ da Lei n. ${ }^{\circ}$ 8.036/90.

Abrimos pequenos parênteses para esclarecer, quanto ao FGTS, que o STF, nos autos do Recurso Extraordinário n. ${ }^{\text { }} 596.478^{259}$, reconheceu a constitucionalidade do art. 19-A da Lei n. ${ }^{\circ}$ 8.036/90. Por ocasião da decisão, a corte em referência entendeu, por um voto de diferença, serem devidos os depósitos de FGTS aos empregados contratados sem observância da regra constitucional que estabelece prévia aprovação em concurso público, ao fundamento de se tratar de norma transitória, de existir previsão constitucional de punição do responsável pela contratação irregular e em razão de a impossibilidade de se retroagir os efeitos da decretação do nulo no contrato de trabalho.

Voltemos às considerações do TST.

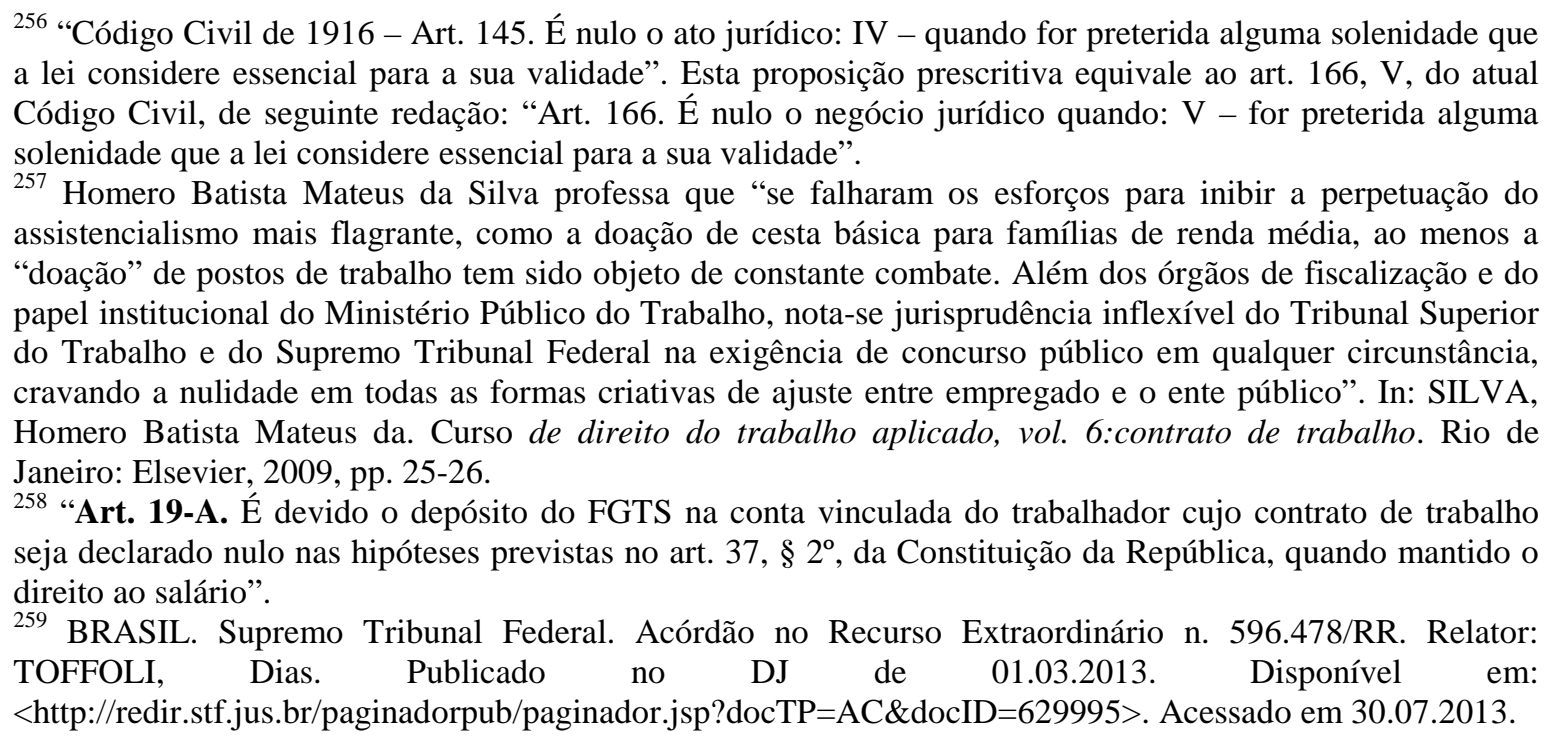


O afastamento da completa ausência de efeitos trabalhistas pautou-se em princípios constitucionais nos quais se funda a própria República Federativa do Brasil, notadamente a dignidade da pessoa humana (art. $1^{\circ}$, III) e o valor social do trabalho (art. $1^{\circ}$, IV). Essas diretrizes acabaram por levar o TST à concessão de direitos mínimos ao trabalhador público, de maneira que os obreiros não fossem reduzidos à condição similar à de escravo, segundo entendimento do próprio tribunal.

Eis o extrato do entendimento do TST ora exposto:

"É fácil deduzir achar-se subjacente ao precedente da Corte interpretação do artigo 37, inciso II, $\S 2^{\circ}$, da Constituição, e do artigo 145, do Código Civil, no cotejo com o artigo $1^{\circ}$ e seus incisos III e IV, do Texto Constitucional, segundo os quais a República Federativa do Brasil, formada pela união indissolúvel dos Estados e Municípios e do Distrito Federal, constitui-se em Estado Democrático de Direito e tem como fundamentos: ... III a dignidade da pessoa humana; IV os valores sociais do trabalho e da livre iniciativa; ... . Significa dizer que, não obstante a nulidade do contrato sem o precedente do certame público, os princípios constitucionais em que se funda a própria República Federal do Brasil, de respeito à dignidade da pessoa humana e aos valores sociais do trabalho, impuseram a conclusão de se garantir ao trabalhador público direitos mínimos que o colocassem a salvo da condição similar ao escravo.",260

Fixadas as bases teóricas da Súmula n. ${ }^{\circ}$ 363, é mister analisar, ainda, os fundamentos do mesmo órgão jurisdicional que pautaram o elastecimento da posição acima referida para as hipóteses de anulação do concurso público. Inicie-se essa segunda parte com a orientação jurisprudencial objeto do estudo:

“OJ-SDI2-128 - Ação rescisória. Concurso público anulado posteriormente. Aplicação do enunciado 363 do TST. O certame público posteriormente anulado equivale à contratação realizada sem a observância da exigência contida no art. 37, II, da Constituição da República de 1988. Assim sendo, aplicam-se à hipótese os efeitos previstos no Enunciado 363 do TST".

Apesar da clareza das proposições contidas no verbete acima, é de maior importância ao pesquisador do Direito o estudo dos precedentes jurisprudenciais que subsidiaram a cristalização do verbete, pois, só assim, restarão apuradas suas verdadeiras razões ou fundamentos. Os precedentes da Orientação Jurisprudencial n. ${ }^{\circ} 128$ da SDI-II do TST, em um total de quatro, são da relatoria do Ministro Ives Gandra Martins Filho,

${ }^{260}$ BRASIL. Tribunal Superior do Trabalho. Acórdão no processo TST-RXOFROAR-71842/2002-900-1100.0. Relator: LEVENHAGEN, Antônio José de Barros. Disponível em: <https://aplicacao5.tst.jus.br/consultaProcessual/consultaTst.do?conscsjt=\&numeroTst=71842\&anoTst=2002 $\&$ varaTst $=900 \& \operatorname{trtTst}=11 \&$ seqTst $=00 \&$ consulta $=$ Consultar $>$. Acessado em 28.12.2013. 
processos $n^{\circ}$ TST-RXOFROAR-371/2002-000-07-00.3 $3^{261}$ e TST-RXOFAR-816843/01.7 $7^{262}$, e do Ministro Emmanoel Pereira, processos no TST-RXOFROAR-60.245/2002-900-07$00.1^{263}$ e TST-RXOFROAR-59.922/2002-900-07-00.9 $9^{264}$.

No acórdão exarado no processo $\mathrm{n}^{\circ}$ TST-RXOFROAR-371/2002-000-07-00.3 consignou-se que:

\begin{abstract}
"No entanto, a hipótese dos autos não se resume à discussão da estabilidade das Reclamantes, tendo em vista que elas foram demitidas com fundamento na decretação de nulidade do concurso público do qual participaram.
\end{abstract}

A questão da correção do ato administrativo que anulou o concurso público não está sendo controvertida nos presentes autos, mesmo porque tal matéria está fora da competência da Justiça do Trabalho.

Assim, tem-se como ponto pacífico que o concurso foi ilegal e/ou fraudulento, razão pela qual todo o certame restou contaminado, não restando à Administração senão dispensar todos os servidores contratados por meio do referido concurso.

Ora, quando a Constituição da República exige a prestação de concurso público presume, obviamente, que se trate de um concurso legítimo, realizado de acordo com a legislação e no qual foi garantido a todos os candidatos igualdade de condições.

Na hipótese dos autos, o concurso público foi anulado, de modo que a Administração não tem sustentação legal para efetuar contratações. Se houve contratação, estas equivalem à contratação sem concurso público, para as quais se aplica a Súmula $\mathrm{n}^{\circ} 363$ do TST, cabendo às Reclamantes tão-somente o pagamento da importância dos dias trabalhados (...)" (negrito não consta no original)",265.

${ }^{261}$ BRASIL. Tribunal Superior do Trabalho. Acórdão no processo TST-RXOFROAR-371/2002-000-07-00.3. Relator: MARTINS FILHO, Ives Gandra. Disponível em: <https://aplicacao5.tst.jus.br/consultaProcessual/consultaTst.do?conscsjt=\&numeroTst=371\&anoTst=2002\& varaTst $=000 \& \operatorname{trtTst}=07 \&$ seqTst $=00 \&$ consulta $=$ Consultar $>$. Acessado em 28.12.2013.

${ }^{262}$ BRASIL. Tribunal Superior do Trabalho. Acórdão no processo TST-RXOFAR-816843/01.7. Relator: MARTINS FILHO, Ives Gandra. Disponível $<$ https://aplicacao5.tst.jus.br/consultaProcessual/consultaTst.do?conscsjt=\&numeroTst=816843\&anoTst=200 $1 \&$ varaTst $=\& \operatorname{trtTst}=\&$ seqTst $=\&$ consulta $=$ Consultar $>$. Acessado em 28.12.2013.

${ }^{263}$ BRASIL. Tribunal Superior do Trabalho. Acórdão no processo TST-RXOFROAR-60.245/2002-900-0700.1. Relator: PEREIRA, Disponível em: $<$ https://aplicacao5.tst.jus.br/consultaProcessual/consultaTst.do?conscsjt=\&numeroTst=60245\&anoTst=2002 $\&$ varaTst $=\& \operatorname{trtT} \mathrm{st}=\&$ seqTst $=\&$ consulta=Consultar $>$. Acessado em 28.12.2013.

${ }^{264}$ BRASIL. Tribunal Superior do Trabalho. Acórdão no processo TST-RXOFROAR-59.922/2002-900-0700.9. Relator: PEREIRA, Disponível em: $<$ https://aplicacao5.tst.jus.br/consultaProcessual/consultaTst.do?conscsjt=\&numeroTst=59922\&anoTst=2002 $\&$ varaTst $=\& \operatorname{trtT} \mathrm{st}=\&$ seqTst $=\&$ consulta=Consultar $>$. Acessado em 28.12.2013.

${ }^{265}$ BRASIL. Tribunal Superior do Trabalho. Acórdão no processo TST-RXOFROAR-371/2002-000-07-00.3. Relator: MARTINS FILHO, Ives Gandra. Disponível em: <https://aplicacao5.tst.jus.br/consultaProcessual/consultaTst.do?conscsjt=\&numeroTst=371\&anoTst=2002\& varaTst $=000 \& \operatorname{trtTst}=07 \&$ seqTst $=00 \&$ consulta $=$ Consultar $>$. Acessado em 28.12.2013. 
O segundo precedente apenas reafirma tal raciocínio:

\begin{abstract}
"A contratação por meio de concurso público que, incontrovertidamente, foi anulado, equivale à contratação sem concurso público (cfr. Nesse sentido: TST-RXOFROAR-371/2002-000-07-00.3, Rel. Min. Ives Gandra Filho, in DJ de 23/05/03), de forma que se impõe, irremediavelmente, o reconhecimento do retorno do Empregado ao status quo anterior, ou seja, ao regime jurídico que ele mantinha antes de sua nomeação e posse em virtude da aprovação no referido concurso público,"266.
\end{abstract}

O Ministro Emmanoel Pereira, nos autos do processo $n^{\circ}$ TST-RXOFROAR60.245/2002-900-07-00.1, consignou que:

"A contratação efetivada com ente da administração pública não produz
efeitos jurílicos, se o certame público posteriormente for anulado. Trata-
se de hipótese similar à contratação realizada sem a observância da
exigência contida no artigo 37 , inciso II, da Constituição da República de
1988 , que, por ser nula de pleno direito, não produz quaisquer efeitos
jurídicos, remanescendo o direito do contratado apenas ao salário
correspondente aos dias efetivamente trabalhados"267 (ênfase dada).

Do outro processo da relatoria do Ministro Emmanoel Pereira, processo $n^{\circ}$ TST-

RXOFROAR-59.922/2002-900-07-00.9, extrai-se que:

"A questão do mérito do ato administrativo que anulou o concurso está fora da competência da Justiça do Trabalho, conforme já demonstrado. Assim, como ponto pacífico, aceita-se a anulação do concurso, que teve como consequiência a demissão dos Reclamantes e de todos os servidores contratados por seu intermédio, por falta de sustentação legal.

A contratação por meio de certame que foi anulado é o mesmo que contratação sem concurso público. E se foi realizada por ente público, após a Constituição de 1988, é nula, devendo o servidor contratado ser dispensado, cabendo tão-somente o pagamento pelos dias efetivamente trabalhados, incidindo o Enunciado no 363 do TST",268.

Para a Corte Trabalhista, a Administração Pública só pode realizar contratações

${ }^{266}$ BRASIL. Tribunal Superior do Trabalho. Acórdão no processo TST-RXOFAR-816843/01.7. Relator: MARTINS FILHO, Ives Gandra. Disponível em: $<$ https://aplicacao5.tst.jus.br/consultaProcessual/consultaTst.do?conscsjt=\&numeroTst=816843\&anoTst=200 $1 \&$ varaTst $=\& \operatorname{trtT} \mathrm{st}=\&$ seqT $\mathrm{st}=\&$ consulta $=$ Consultar $>$. Acessado em 28.12.2013.

${ }^{267}$ BRASIL. Tribunal Superior do Trabalho. Acórdão no processo TST-RXOFROAR-60.245/2002-900-0700.1. Relator: PEREIRA, Emmanoel. Disponível em: $<$ https://aplicacao5.tst.jus.br/consultaProcessual/consultaTst.do?conscsjt=\&numeroTst=60245\&anoTst=2002 $\&$ varaTst $=\& \operatorname{trtT} \mathrm{st}=\&$ seqTst $=\&$ consulta $=$ Consultar $>$. Acessado em 28.12.2013.

${ }^{268}$ BRASIL. Tribunal Superior do Trabalho. Acórdão no processo TST-RXOFROAR-59.922/2002-900-0700.9. Relator: PEREIRA, Emmanoel. Disponível em: $<$ https://aplicacao5.tst.jus.br/consultaProcessual/consultaTst.do?conscsjt=\&numeroTst=59922\&anoTst=2002 $\&$ varaTst $=\& \operatorname{trtTst}=\&$ seqTst $=\&$ consulta=Consultar $>$. Acessado em 28.12.2013. 
seguindo os procedimentos constitucional (art. 37, II) e legal (criação do emprego público e demais generalidades). $\mathrm{O}$ desrespeito a referidos ditames, seja, originariamente, pela ausência de certame público, seja, supervenientemente, em decorrência de declaração de nulidade do concurso público realizado, implica idênticos resultados, quais sejam, rescisão do contrato, pagamento das horas trabalhadas e do FGTS.

Portanto, o TST entende o concurso público como pressuposto de vinculação do cidadão com a Administração ${ }^{269}$ ou como pressuposto de validade da relação de emprego $^{270}{ }^{271}$, de modo que sua ausência ou anulação acarreta a concessão de direitos mínimos para que o trabalhador não seja colocado em situação assemelhada à escravidão. A concessão mínima de direitos se funda na ausência ou na perda da base legal da contratação, pois, na hipótese da Súmula 363, inexiste autorização para contratação sem concurso e, no caso da OJ 128 da SDI-II, a declaração de nulidade do certame faz cessar sua base normativa ou sua autorização legal.

Ressalte-se, uma vez mais, que o trabalho prestado com os contornos dos arts. $2^{\circ}$ e $3^{\circ}$ da CLT é o que basta à existência de relação de emprego e, nessa diretriz, mesmo que ausente o concurso público, não é apropriado afirmar-se a inexistência de relação de emprego. A bem da verdade, há formação da relação, ainda que em descompasso com o ordenamento jurídico, requisito, que afeta, tão somente, como analisado anteriormente, a validade do negócio jurídico que é causa da relação de emprego ${ }^{272}$.




Contudo, nota-se uma paulatina tendência da Corte trabalhista de expandir a concessão de direitos para hipóteses outrora marginalizadas. Destaca-se a concessão feita pela Orientação Jurisprudencial no 383 da SDI-1 que conferiu a paridade de direitos entre terceirizados e servidores, in literis:

\begin{abstract}
“OJ-SDI1-383 TERCEIRIZAÇÃO. EMPREGADOS DA EMPRESA PRESTADORA DE SERVIÇOS E DA TOMADORA. ISONOMIA. ART. 12, “A", DA LEI No 6.019, DE 03.01.1974 (mantida) - Res. 175/2011, DEJT divulgado em 27,30 e 31.05.2011. A contratação irregular de trabalhador, mediante empresa interposta, não gera vínculo de emprego com ente da Administração Pública, não afastando, contudo, pelo princípio da isonomia, o direito dos empregados terceirizados às mesmas verbas trabalhistas legais e normativas asseguradas àqueles contratados pelo tomador dos serviços, desde que presente a igualdade de funções. Aplicação analógica do art. 12, "a", da Lei no 6.019, de 03.01.1974".
\end{abstract}

Os julgados que ampararam a elaboração da orientação jurisprudencial em relevo indicam que a mais alta Corte Trabalhista valeu-se dos seguintes argumentos na estipulação de identidade de direitos entre os empregados da tomadora de serviço e os empregados da prestadora de serviço: a) interpretação analógica do ar. $12^{273}$ da Lei $\mathrm{n}^{\circ}$ 6.019/1974; b) respeito aos artigos $5^{\circ}$, caput $^{274}$, e $7 .^{\circ}, \mathrm{XXXII}^{275}$, da CR. O cerne da fundamentação repousa no princípio da igualdade, entendido, todavia, para além dos requisitos exigidos para a singela equiparação salarial (art. 461 da CLT). Com efeito, o TST vai longe, utiliza um direito fundamental, a igualdade, para a concessão de direitos a cidadãos-trabalhadores outrora negligenciados pelos órgãos jurisdicionais da Justiça do Trabalho.

As novidades não cessam com essa Orientação Jurisprudencial, pois, em 13.02.2012, o TST divulgou a Súmula 430, de seguinte conteúdo:

existência do ato ou negócio é a presença de seus elementos constitutivos. Eventual vício de que estes padeçam não afeta a existência do contrato, repercutindo apenas em sua validade, aspectos que não devem ser confundidos. E se houve prestação de trabalho, as consequências do labor prestado devem ser tratadas segundo as particularidades do contrato em que aquele estava inserido, isto é, segundo as condições em que o trabalho foi executado, e não com base em regras de outro contrato qualquer". In: LORENZETTI, Ari Pedro. As nulidades o direito do trabalho. 2.ed. São Paulo: LTr, 2010, p. 30.

273 "Art.12. Ficam assegurados ao trabalhador temporário os seguintes direitos: a) remuneração equivalente à percebida pelos empregados de mesma categoria da empresa tomadora ou cliente calculados à base horária, garantida, em qualquer hipótese, a percepção do salário mínimo regional”.

274 “Art.5 $5^{\circ}$ Todos são iguais perante a lei, sem distinção de qualquer natureza, garantindo-se aos brasileiros e aos estrangeiros residentes no País a inviolabilidade do direito à vida, à liberdade, à igualdade, à segurança e à propriedade, nos seguintes termos".

275 "Art. $7^{\circ}$, XXXII - proibição de distinção entre trabalho manual, técnico e intelectual ou entre os profissionais respectivos". 
"SUM-430 ADMINISTRAÇÃOO PÚBLICA INDIRETA. CONTRATAÇÃO. AUSÊNCIA DE CONCURSO PÚBLICO. NULIDADE. ULTERIOR PRIVATIZAÇÃO. CONVALIDAÇÃO. INSUBSISTÊNCIA DO VÍCIO - Res. 177/2012, DEJT divulgado em 13, 14 e 15.02.2012. Convalidam-se os efeitos do contrato de trabalho que, considerado nulo por ausência de concurso público, quando celebrado originalmente com ente da Administração Pública Indireta, continua a existir após a sua privatização".

A adoção da convalidação do nulo indica o distanciamento do TST dos preceitos civilistas aplicáveis às situações de invalidade, isso porque a aplicação isolada das disposições do Direito Comum impediria a convalidação, por expressa previsão do art. 169 do Código Civil. Essa nova Súmula demonstra de maneira clara o avanço da jurisprudência trabalhista em direção à ampla oferta de direitos, o que atende a mandamentos constitucionais, como o valor social do trabalho.

Também, a já mencionada decisão proferida nos autos do processo TST-E-EDRR-4800-05.2007.5.10.0008 ${ }^{276}$, que afastou a incidência dos rigores da Súmula n. 363 de contratações ocorridas até o julgamento do Mandado de Segurança 21.322-1/DF pelo $\mathrm{STF}^{277}$, implicou avanço da jurisprudência em sentido favorável aos trabalhadores.

Dessa forma, é perceptível o avanço da jurisprudência trabalhista, que parte do reconhecimento de vínculo de emprego para as relações anteriores à Constituição de 1988, passa pela amarga reação às relações de emprego à margem do concurso público e amadurece, ainda que de forma tímida ou esparsa, para a concessão ampla de direitos aos trabalhadores.

\footnotetext{
${ }^{276}$ BRASIL. Tribunal Superior do Trabalho. Acórdão no processo TST-E-ED-RR-4800-05.2007.5.10.0008. Relator: VEIGA, Aloysio Corrêa da Disponível em:

$<$ https://aplicacao5.tst.jus.br/consultaProcessual/decisaoForm.do?numInt=430500\&anoInt=2008\&codOrgaoJ udic $=53 \&$ anoPauta $=2013 \&$ numPauta $=15 \&$ tipSessao $=O>$. Acessado em 28.12.2013.

277 BRASIL. Supremo Tribunal Federal. Acórdão no Mandado de Segurança n. 21.322-1/DF. Relator: BROSSARD, Paulo. Publicado no DJ de 23.04.1993. Disponível em $<$ http://redir.stf.jus.br/paginadorpub/paginador.jsp?docTP=AC\&docID=85492>. Acessado em 30.06.2013.
} 


\section{IDENTIFICAÇÃO DO CONFLITO.}

O válido preenchimento de empregos públicos está atrelado à prévia aprovação do trabalhador em concurso público. Mas, em diversos casos, corriqueiros na estrutura administrativa brasileira, dá-se a prestação de trabalho subordinado nos moldes dos artigos $2^{\circ}$ e $3^{\circ}$ da CLT sem o atendimento do pressuposto formal estabelecido pelo Texto Magno $^{278}$ e, não raras vezes, sem que o trabalhador tenha conhecimento da natureza jurídica de seu empregador, isto é, sem que ele saiba que o tomador de sua força de trabalho é integrante da Administração Pública. Todavia, a gravidade não se encerra na negligência do mandamento constitucional, ela vai além, porquanto a Administração não oferta direitos aos trabalhadores que atuaram em seu benefício e estavam de boa-fé.

É relevante notar que a Administração Pública tutela os interesses da sociedade com a prática de atos jurídicos, termo empregado nesse caso em sua acepção ampla. Nessa direção, o ato administrativo que implica a contratação de trabalhador, independentemente de concurso público, estabelece uma relação de emprego, consagrado em um negócio jurídico, dotado, inexoravelmente, de efeitos no mundo dos fatos, de modo que sua reprimenda também se dará por outro ato administrativo ou, no caso de ocorrer no seio de um processo judicial, por decisão judicial, em que pese preponderar o entendimento no sentido de que o nulo não deve gerar efeitos ou direitos ${ }^{279} 280$.

\footnotetext{
278 "O âmbito dessas irregularidades não se restringe somente em afrontas à Constituição Federal. Na realidade, a grande maioria desses atos é praticada na esfera administrativa, em inobservância às leis e regulamentos estaduais, principalmente em matéria tributária". In: CINTRA, Weiler Jorge; JÚNIOR, Weile Jorge Cintra. O "princípio" da ilegalidade eficaz. Revista Jurídica da Universidade de Franca. Ano 3, n. ${ }^{\circ}$, maio. Franca. 2000, p. 193.

279 "Somente existe o direito adquirido se provindo de norma jurídica válida. Inexiste direito adquirido originário de norma nula. $\mathrm{O}$ nulo não gera direitos. A situação jurídica protegida apenas ocorre quando o legislador ou, o administrador, pretende torná-la intocável por qualquer alteração posterior. Ainda que a pretensão fosse certa, não poderia ela merecer o amparo do ordenamento jurídico, uma vez que o calço, o alicerce, o fundamento, é desprovido de segurança, já que inválido”. In: OLIVEIRA, Regis Fernandes. A proteção da boa-fé no Direito Administrativo. Revista dos Tribunais. ano 82 - fevereiro de 1993, vol. 688, p. 267.

${ }^{280}$ Rocco Favale observa que não são copiosos os estudos sobre a atenuação dos pressupostos formais em razão da boa-fé ao afirmar que "tutavia è mancata nel nostro modello una sensibilità verso una "umanizzazone" dell'elemento formale attraverso sforzi interretativi orietai ad attenuare le dre conseguenze invalidanti legate alle ipotese di sua deficienza. Sensiblitá a umanizzazione che invece hanno caratterizzato gli sforzi dottrinali e non meno giurisprudenziali tedeschi diretti a mitigare le pesanti ripercusioni previste dalla legge.

(...)

I canoni accolti dagli ultimi arresti del Reichsgericht, secondo i quali il principio di buona fede, in presenza di determinae circostanze, può costringere le parti ad adempiere anche prestazioni scaturenti da negozi privi di forma ad substancam, rappresenano ancor oggi gli schemi dominanti”. In: FAVALE, Rocco. Nullità del contratto per difetto di forma. Rassegna di diritto civile. Saggi. 3/2003, pp. 561-562 e 570.
} 
Ocorre que, como dito, os trabalhadores envoltos nessa relação eivada de nulidade podem não possuir conhecimento do vício, atuando amparados em expectativas geradas por dizeres e condutas da própria Administração Pública, o que justifica a discussão acerca da preservação de direitos trabalhistas ou, até mesmo, se a ilicitude deve ou não prevalecer.

A esses trabalhadores admitidos pela Administração Pública sem a prévia aprovação em concurso público e sem o conhecimento da natureza jurídica de seu empregador, aplicam-se, no mínimo, normas de Direito do Trabalho e de Direito Administrativo, ainda que muitas delas repousem na CR, ou seja, a ausência de concurso público atrai, ao menos em tese, a aplicação de proposições prescritivas próprias de diversas especialidades do Direito.

Logo, estamos diante de negócio jurídico nulo por vício quanto à forma em que ao menos um de seus sujeitos está de boa-fé e dispôs de sua energia em favor da contraparte, circunstância insuscetível de retorno ao estado anterior.

\section{Nulo e anulável nos Direitos Civil, Trabalhista e Administrativo.}

No Direito Civil, os vícios podem gerar a nulidade absoluta ou a nulidade relativa também chamada anulabilidade, conforme se extrai dos arts. $166^{281}$ e $171^{282}$ do Código Civil. Zeno Veloso pontifica que, nos campos do Direito Civil, as figuras em proeminência distinguem-se nos seguintes aspectos: a nulidade tutela interesses gerais, a anulabilidade, visa, em geral, a proteger interesses privados, individuais; somente o direito de suscitar a anulabilidade decai com o passar do tempo; a nulidade é insuprível, insanável e não permite confirmação, já a anulabilidade pode ser sanada; a nulidade pode ser decretada, ex officio, pelo juiz e, em qualquer caso, pode ser alegada pelo Ministério público, ao passo que a anulabilidade não pode ser declarada, ex officio, nem postulada pelo Ministério Público; a nulidade por ser invocada por qualquer interessado, ao passo que a anulabilidade, somente, o pode pela parte para cuja proteção foi estabelecida; o negócio jurídico nulo não produz efeitos jurídicos típicos; o anulável produz efeitos, enquanto não

\footnotetext{
281 “Art. 166. É nulo o negócio jurídico quando:...”.

282 “Art. 171. Além dos casos expressamente declarados em lei, é anulável o negócio jurídico:...”.
} 
for anulado; por fim, a anulabilidade está sempre prevista em lei e a nulidade pode ser textual ou implícita ${ }^{283}$.

Também com vistas ao Direito Comum, Seabra Fagundes professa que as categorias de vícios, nulos e anuláveis, diferenciam-se em razão da nulidade ser insanável e impassível de revalidação, enquanto a anulabilidade permite a revalidação com efeito retroativo; sob outro aspecto, pode ser invocada pelo Ministério Público, por qualquer interessada e até de ofício pelo juiz, ao passo que a anulabilidade só será decretada se provocada pela parte interessada ${ }^{284}$.

Ainda, de acordo com Antônio Junqueira de Azevedo, a distinção das espécies de invalidade ampara-se em questões econômicas e sociais, de modo a permitir a manutenção ou a convalidação de negócios jurídicos que possuam vícios menos graves ${ }^{285}$. Efetivamente, a gravidade da infração e a importância do interesse a se resguardar impõem sanções de maior ou menor intensidade, punições mais ou menos severas ${ }^{286}$, o que não significa, porém, que existam graus de invalidade, porquanto a diferença entre nulo e anulável repousa na intensidade da repulsa do Direito pelos negócios inválidos ${ }^{287}$.

Não se pode olvidar que o sistema de invalidades, inclusive sua distinção entre nulo e anulável, é uma questão de política legislativa, vale dizer, vincula-se às proposições estabelecidas pelo Poder Legislativo ${ }^{288}$. Por conseguinte, é possível que as diferentes especialidades do Direito deem tratamentos diversos a respeito da invalidade. Desse modo, as disposições do Direito Civil não incidem, necessariamente, sobre a relação de emprego celebrada com a Administração Pública, mesmo porque os Direitos do Trabalho e Administrativo adotam posições particularizadas sobre as espécies de invalidade do negócio jurídico.

Na seara trabalhista, ocorre a distinção de espécies de invalidade, sempre de acordo com o grau de repulsa estabelecido pela ordem jurídica, entre nulo e anulável. São

\footnotetext{
${ }^{283}$ VELOSO, Zeno. Invalidade do negócio jurídico: nulidade e anulabilidade. 2. ed. Belo Horizonte: Del Rey, 2005, pp. 313-314.

${ }^{284}$ FAGUNDES, Seabra M. O Controle dos Atos Administrativos pelo Poder Judiciário. 4.ed. Rio de Janeiro: Forense, p. 57.

285 "Código Civil. Art. 172. O negócio anulável pode ser confirmado pelas partes, salvo direito de terceiro".

${ }^{286}$ MELLO, Marcos Bernardes de. Teoria do fato jurídico: plano da validade. 9. e.d. São Paulo: Saraiva, 2009, p. 60.

${ }^{287}$ MELLO, Celso Antônio Bandeira de. Curso de Direito Administrativo. 22.ed. São Paulo: Malheiros, 2007, p. 440.

${ }^{288}$ MELLO, op. cit., p. 60.
} 
exemplos deste o desrespeito à forma escrita (ad probationem) dos contratos de trabalho temporário (Lei n 6.019/1974) e daquele, a celebração de contrato por menor de dezesseis anos fora da hipótese do contrato de aprendizagem ${ }^{289}$. Ocorre, todavia, que a impossibilidade de se retroagir a decretação do nulo ao momento da celebração do negócio jurídico acaba por equiparar, em termos práticos, as duas figuras. Desse modo, existindo, em geral, identidade quanto aos efeitos práticos do nulo e do anulável, encontramos em doutrina referências gerais à teoria das nulidades sem o destaque das espécies de invalidade, o que não traz nenhum prejuízo para a mencionada irretroatividade dos efeitos na seara trabalhista 290291 .

A seu turno, Seabra Fagundes afirma a incompatibilidade da cabal aplicação da fundamentação do Direito Civil acerca do nulo e do anulável ao Direito Administrativo, porquanto, neste, os vícios recaem sobre atos que gozam de presunção de legalidade, há a impossibilidade de ratificação do ato administrativo independentemente da espécie de vício e existe a possibilidade de prática de outro ato para sanar o vício do primeiro ${ }^{292} 293$. Igualmente, a distinção entre nulo e anulável é inconciliável com o princípio do interesse público, com a possibilidade de a Administração anular ou declarar nulos atos por ela praticados e com a unilateralidade da maioria dos atos praticados ${ }^{294}$. Todavia, o autor em destaque admite a classificação dos vícios de invalidade em razão da intensidade da ofensa ao interesse público, de modo que seriam absolutamente inválidos ou nulos os atos que violam regras fundamentais ao interesse público; por sua vez, qualificar-se-iam como relativamente inválidos ou anuláveis os atos que violam com menor intensidade regras que dizem respeito ao interesse público; por fim, os atos irregulares seriam aqueles que apresentam defeitos irrelevantes, que não afetam propriamente o interesse público ${ }^{295}$.

\footnotetext{
${ }^{289}$ GOMES, Orlando. GOTTSCHALK, Elson. Curso de direito do trabalho. Rio de Janeiro: Forense, 2006, p. 127.

${ }^{290}$ BARROS, Alice Monteiro de Barros. Curso de direito do trabalho. 7. ed. São Paulo: LTr, 2011, pp. 411417.

${ }^{291}$ DELGADO, Mauricio Godinho. Curso de direito do trabalho. 10. ed. São Paulo: LTr, 2011, p. 505.

292 FAGUNDES, Seabra M. O Controle dos Atos Administrativos pelo Poder Judiciário. 4.ed. Rio de Janeiro: Forense, p. 58.

${ }^{293}$ Nas páginas seguintes destacaremos que, ao menos no âmbito federal, há a possibilidade de convalidação ou aproveitamento dos atos nulos.

${ }^{294}$ Ibidem, p. 60.

${ }^{295}$ Ibidem, pp. 63-67.
} 
Muito embora autores como Marcos Bernardes de Mello defendam a não incidência da distinção das categorias de vícios ao Direito Administrativo ${ }^{296}$, filiamo-nos à linha de pensamento que advoga a aplicação das categorias de vício à seara do Direito em relevo, da qual fazem parte Maria Sylvia Zanella Di Pietro ${ }^{297}$, Celso Antônio Bandeira de Mello $^{298}$ e Zeno Veloso ${ }^{299}$, corrente que aceita a existência do nulo e do anulável, não em razão dos fundamentos civilistas, mas, sim, em razão da possibilidade de se sanar ou convalidar o ato, porquanto seria nulo o ato que não admite convalidação, ao passo que o anulável a admitiria, de acordo com o elemento do ato administrativo violado ${ }^{300}$.

Como arremate dos dizeres anteriores, pode-se afirmar que os Direitos Civil, Trabalhista e Administrativo aceitam a divisão da invalidade em nulo e anulável e que a violação ao concurso público, por consistir em forma necessária à validade do ato, implica a figura mais severa, qual seja, a nulidade do negócio jurídico de emprego. Logo, a não observância do concurso público, forma prescrita em lei, indispensável à substância do negócio jurídico, constitui invalidade que recebe grande repulsa pela ordem jurídica, de modo a se enquadrar como nulo o ato negocial que não a observa.

\section{Enfoque trabalhista.}

As distinções entre o Direito do Trabalho e outras searas da ciência jurídica são diversas, tantas que chegam a justificar a sua classificação como ramo próprio, especializado. E a doutrina da nulidade é uma delas, pois as diversas ramificações do Direito possuem problemas distintos e, consequentemente, clamam por soluções diversas.

Como diretriz geral, sendo nulo, o negócio jurídico não deveria produzir efeitos, pois, desde sua origem, está eivado de irregularidade. No entanto, como já observado, estamos diante da prestação de trabalho por ser humano e o investimento de sua energia

\footnotetext{
${ }^{296}$ MELLO, Marcos Bernardes de. Teoria do fato jurídico: plano da validade. 9. e.d. São Paulo: Saraiva, 2009 , p. 64.

${ }^{297}$ DI PIETRO, Maria Sylvia Zanella. Direito Administrativo. 17.ed. São Paulo: Atlas, 2004, p. 235.

${ }^{298}$ MELLO, Celso Antônio Bandeira de. Curso de Direito Administrativo. 22.ed. São Paulo: Malheiros, 2007, p. 441.

${ }^{299}$ VELOSO, Zeno. Invalidade do negócio jurídico: nulidade e anulabilidade. 2. ed. Belo Horizonte: Del Rey, 2005, pp. 321-322.

${ }^{300}$ DI PIETRO, loc. cit.
} 
física ou intelectual, bem incorpóreo, incapaz de ser restituído, o que acaba por delinear a distinção entre as nulidades no Direito do Trabalho e no Direito Civil ${ }^{301}$.

O não atendimento da forma prescrita em lei implica a nulidade do negócio jurídico. Nos limites do Direito Comum, notadamente no Direito Civil, há expressa menção à nulidade do negócio jurídico para as hipóteses em observação, eis a redação:

“Art. 166. É nulo o negócio jurídico quando:

IV - não revestir a forma prescrita em lei”;

Mencionada previsão consagra norma jurídica semelhante à revelada pelas proposições prescritivas contidas no art. 37 , II e $\S 2^{\circ}$, da CR. Em outras palavras, a não observância da forma - na hipótese, o concurso público - implica a nulidade do contrato de emprego. Depreende-se do cotejo desses dispositivos com o art. 442 da CLT nítido caso de exceção à regra do Direito do Trabalho, qual seja, a liberdade de formas.

Pois bem, violada a forma que diz respeito à substância do negócio jurídico, e não à singela prova do ato negocial, estaremos diante de vício de validade que possui como consequência jurídica sua nulidade que, em uma visão panorâmica, acarreta a ausência de produção de efeitos próprios do negócio jurídico. A esse respeito, encontra-se no Direito Civil norma que impõe a restituição dos sujeitos do contrato ao estado anterior ao da celebração do negócio e, na impossibilidade, a indenização pelo equivalente, eis a norma em comento:

“Art. 182. Anulado o negócio jurídico, restituir-se-ão as partes ao estado em que ante dele se achavam e, não sendo possível restituí-las, serão indenizadas com o equivalente".

A redação do art. 182 do Código Civil indica, como diretriz primeira, o retorno dos sujeitos ao estado anterior, em outras palavras, pretende afastar a produção de qualquer efeito próprio do ato negocial praticado. Tem-se, desse modo, que os efeitos da declaração de nulidade operam-se desde seu nascedouro, ex tunc, vale registrar, retroagem ao momento da celebração do negócio jurídico.

Ocorre que o Direito do Trabalho não compadece com os efeitos da decretação da nulidade, com especial razão por consistir o trabalho em dispêndio de energia física e

\footnotetext{
${ }^{301}$ SILVA, Homero Batista Mateus da. Curso de direito do trabalho aplicado, vol. 6: contrato de trabalho.
} Rio de Janeiro: Elsevier, 2009, p. 26. 
intelectual e, por isso mesmo, insuscetível de restituição. Se a nulidade tivesse, nesse ramo, o efeito retroativo que tem no Direito Civil, repondo os contratantes ao estado anterior em que se encontravam ao estipular o contrato nulo, ficaria impedido o trabalhador de exigir seus direitos, o que não pode ser aceito.

Além disso, a retroatividade só teria cabimento se o empregador - no caso em estudo, a Administração Pública - pudesse devolver ao empregado a energia que este gastou no trabalho, o que é impossível. Portanto, aplicada a diretriz geral a respeito das nulidades, ocorreria a unilateralidade da retroatividade, em franco prejuízo ao empregado, pois somente o tomador dos serviços se beneficiaria, apropriando-se do resultado do trabalho definitivamente prestado sem o correspondente pagamento ${ }^{302}$.

Em suma, no contrato de emprego com a Administração Pública sem a observância do concurso público, em função da natureza do trabalho, é impossível a restituição ao estado anterior, pois, como ensinado por Homero Batista Mateus da Silva, o trabalho é energia física, bem incorpóreo, incapaz de ser restituído ${ }^{303}$, o que leva à impossibilidade de aplicação da primeira alternativa indicada pelo art. 182 do Código Civil.

Como alternativa para os casos de impossibilidade de retorno ao estado anterior, há quem sustente a produção de efeitos em negócio jurídico nulo, mediante a indenização com o equivalente. Orlando Gomes e Elson Gottschalk identificam pensamentos doutrinários que defendem o recebimento do salário em contrato nulo por força da proibição do enriquecimento sem causa, que ocorreria na hipótese de a Administração Pública se apropriar do resultado do trabalho alheio sem nenhuma contraprestação ${ }^{304}$.

Todavia, a indenização do valor equivalente não parece adequada à relação de emprego, porquanto o equivalente ao trabalho subordinado somente pode ser comutado com o pagamento de todas as parcelas previstas na legislação trabalhista ${ }^{305}$, prejudicando, assim, a incidência da parte final do art. 182 do Código Civil. Mas, não só por isso, se

${ }^{302}$ GOMES, Orlando. GOTTSCHALK, Élson. Curso de direito do trabalho. Rio de Janeiro: Forense, 2006, pp. 127-128.

${ }^{303}$ SILVA, Homero Batista Mateus da. Curso de direito do trabalho aplicado, vol. 6:contrato de trabalho. Rio de Janeiro: Elsevier, 2009, p. 25.

${ }^{304}$ GOMES, op. cit., p. 128.

${ }^{305}$ CRUZ, Alexandre Corrêa da. Os efeitos da contratação sem concurso pelo ente público: da impropriedade do enunciado 363 do TST. Disponível em: <http://www.femargs.com.br/revista03_cruz.html>. Acesso em 14.12.2012. 
afastada a ressaltada norma, impera, também, observar que a relação de emprego possui obrigações não pecuniárias, como a de anotar a Carteira de Trabalho e Previdência Social $^{306}$, de modo que a comutatividade do contrato de emprego não se resume às obrigações de pagar, o que agrava, sobremaneira, a simples retribuição do nulo com o pagamento de salário em sentido estrito.

Ponto relevante nesta discussão diz respeito à natureza imperativa ${ }^{307} 308$ das normas jurídicas que se ocupam da relação de trabalho. Com isso, não poderiam, de maneira lícita, empregado e empregador dispor sobre a generalidade dos direitos próprios dessa relação ${ }^{309}$, nem mesmo deveria a Administração Pública adimplir unicamente uma parcela mínima dos direitos devidos ou, de modo mais severo, nenhum direito. Do mesmo modo, é de grande relevo o interesse perseguido pelo Direito do Trabalho, qual seja, a proteção do trabalhador em atividades lícitas, de modo que o trabalho prestado deve ser retribuído $^{310}$, mesmo porque o valor social do trabalho possui assento na Constituição como fundamento da República.

Adicionalmente, o oferecimento de tratamento distinto às nulidades trabalhistas não se cuida de argumentação nova, porquanto já era defendida por Mario De La Cueva, que amparava a necessidade de diferenciação na impossibilidade de se devolver aos obreiros a energia por eles despendidas na execução de suas tarefas, o que torna inviável a

\footnotetext{
306 “Consolidação das Leis do Trabalho. Art. 29. A Carteira de Trabalho e Previdência Social será obrigatoriamente apresentada, contra recibo, pelo trabalhador ao empregador que o admitir, o qual terá o prazo de quarenta e oito horas para nela anotar, especificamente, a data de admissão, a remuneração e as condições especiais, se houver, sendo facultada, a adoção de sistema manual, mecânico ou eletrônico, conforme instruções a serem expedidas pelo Ministério do Trabalho".

${ }^{307}$ Professam Orlando Gomes e Elson Gottschalk que "a rigor doutrinário, as leis de ordem pública não se confundem com as leis imperativas. Estas, como instrumento destinado a impedir o desvirtuamento do princípio da autonomia da vontade, decorrente da desigualdade econômica e social dos sujeitos do contrato de trabalho, podem proteger interesses privados. Aquelas, no que toca ao Direito Privado, seriam as que fazem as bases jurídicas sobre as quais repousam a ordem econômica ou moral de uma sociedade determinada (De Page). Protegem, nessa conformidade, sempre, interesses públicos”. In: GOMES, Orlando. GOTTSCHALK, Élson. Curso de direito do trabalho. Rio de Janeiro: Forense, 2006, p. 130.

308 As normas imperativas contrapõem-se às norma supletivas que de acordo com Carlos Maximiliano “considera-se permissiva, supletiva ou dispositiva a lei quando os seus preceitos não são impostos de modo absoluto, prevalecem no caso de silêncio das partes, isto é, se estas não determinaram, nem convencionaram procedimento diverso". In: MAXIMILIANO, Carlos. Hermenêutica e aplicação do direito. Rio de Janeiro: Forense, 2008, p. 178.

309 CUEVA, Mario De La. El nuevo derecho mexicano del trabajo: historia, princípios fundamentales, derecho individual y trabajos especiales. Mexico: Editorial Porrua, 1977, p. 206.

${ }^{310}$ CUEVA, loc. cit.
} 
retroatividade de efeitos nos casos de nulidade trabalhista e implica a concessão de todos os benefícios ou direitos ao trabalhador ${ }^{311}$.

Com efeito, a relação de trabalho é marcada pela indisponibilidade das normas que a regulam, pela impossibilidade de se devolver as partes ao estado anterior nos casos de invalidade e, principalmente, pela finalidade do Direito do Trabalho, qual seja, a proteção do trabalhador.

A falta de apego do Direito do Trabalho às soluções civilistas apresentadas para os casos de inobservância de forma prescrita em lei não esvai o estudo das nulidades, uma vez que, nas contratações sem concurso público, o Direito Administrativo encontra relevante incidência, tendo em vista que as regras e princípios que dizem respeito a essa especial forma de seleção de empregados repousam na CR, no título III, capítulo VII, denominado "DA ADMINISTRAÇÃO PÚBLICA", o que empolga o enfrentamento da teoria das nulidades sob o enfoque administrativista.

\section{Enfoque administrativista. Invalidação ou anulação. Convalidação. Teoria do fato consumado.}

Inicialmente, a exemplo do que se verifica no Direito do Trabalho, as normas próprias do Direito Administrativo não permitem elisão pela vontade dos sujeitos da relação jurídica, pois dotadas da imperatividade própria da tutela do interesse público ${ }^{312}$. Desse modo, há identidade entre o Direito do Trabalho e o Direito Administrativo no que toca à impossibilidade de modificação de um conteúdo, muito embora no caso do Direito

\footnotetext{
${ }^{311}$ Vejamos a íntegra dos relevantes ensinamentos do mestre mexicano: "el art. 2226 del Código civil previne que "cuando se pronuncie por el juez la nulidad, los efectos que se hubiesen producido serán destruidos retroactivamente"; así, a ejemplo, si se pronuncia la nulidad de un contrato de compraventa, el comprador devolverá el bien y el comprador el precio, dos cosas que salieron de um patrimônio, entraron en otro al que no pertenecían, para regresar finalmente a su lugar de origen. Esa solución no podría aplicarse al derecho del trabajo, pues la decisíon que pronuncie la nulidad de una relacíon laboral por no haber alcanzado el menor la edad mínima de admisión al trabajo o por no haber obtenido el patrono el consentimiento del padre o tutor, si bien podria impedir que se continúe prestando el trabajo, no puede lograr que se restituya al trabajador la energía de trabajo que entrego al patrono, de donde resultaría absurdo ya no que se obligaria, sino simplemente que se planteara la devolucíon de los salários que recebió. Em estas condiciones, desaparece toda posibilidad de destruir retroactivamente los efectos que se hubiesen producido por la aplicación de las leyes laborales a la prestación del trabajo; por lo contrario, su aplicación debe ser total, lo que quiere decir que el trabajador deberá recibir todos los beneficios que correspondam al trabajo que hubiese prestado: salarios, primas o una indemnización em el caso infortunado de que resulte víctima de um riesgo de trabajo". In: CUEVA, Mario De La. El nuevo derecho mexicano del trabajo: historia, princípios fundamentales, derecho individual y trabajos especiales. Mexico: Editorial Porrua, 1977, p. 208.

${ }^{312}$ MAXIMILIANO, Carlos. Hermenêutica e aplicação do direito. Rio de Janeiro: Forense, 2008, p. 176.
} 
do Trabalho a impossibilidade diga respeito a um conteúdo mínimo, ao passo que no Direito Administrativo a integralidade do conteúdo é estabelecida por normas jurídicas, ao menos é o que decorre da aplicação isolada do princípio da legalidade previsto no art. $37, \S$ $2^{\circ}$, da CR.

É imperioso que um Estado Democrático de Direito ampare sua atuação em normas jurídicas, o que acaba por corroborar sua previsibilidade e por indicar, de modo claro, os limites e as possibilidades de sua atuação. Quer dizer que a atuação da Administração Pública, que se efetiva por meio de atos administrativos, deve ocorrer nos termos da lei, acarretando o agir em descompasso a necessidade de correção, o que traz à tona figuras como anulação e convalidação dos atos administrativos, que, em uma singela definição, podem ser compreendidos como os atos jurídicos em sentido amplo praticados pela Administração Pública.

Afirma Weida Zancarer que a restauração da ordem jurídica, em prestígio ao princípio da legalidade, pode ocorrer por meio da invalidação e da convalidação ${ }^{313}$. A invalidação é a eliminação, com eficácia retroativa (ex tunc) de um ato administrativo ou da relação jurídica por ele estabelecida, em razão de terem sido estabelecidos em descompasso com as normas jurídicas vigentes. Todavia, é a própria autora que informa a relativização da eficácia ex tunc da invalidação em casos em que o ato ou a relação jurídica por ele criada atinja terceiros de boa-fé ou em razão do princípio que veda o enriquecimento sem causa, situações em que operará a eficácia ex nunc ${ }^{314}$. Quanto à convalidação, pode ser conceituada como o ato exarado pela Administração direcionado especificamente ao ato a convalidar, com a finalidade de suprir seus defeitos e proteger os efeitos por ele produzidos ${ }^{315}$.

Sob o aspecto normativo, faz-se necessária, tendo em vista os contornos do federalismo adotado na vigente Constituição, que confere aos entes federativos, além de outras, autonomia administrativa e legislativa ${ }^{316} 317318$ 319, a aferição da existência de

\footnotetext{
313 ZANCANER, Weida. Da convalidação e da invalidação dos atos administrativos. 2.ed. $3^{\mathrm{a}}$ tiragem 03.2001. São Paulo: Malheiros, 2008, p. 65.

${ }^{314}$ Ibidem, pp.53-54.

315 Ibidem, p. 65.

316 “Art. 18. A organização político-administrativa da República Federativa do Brasil compreende a União, os Estados, o Distrito Federal e os Municípios, todos autônomos, nos termos desta Constituição".

317 "Art. 25. Os Estados organizam-se e regem-se pelas Constituições e leis que adotarem, observados os princípios desta Constituição".
} 
regulamentação específica de cada um deles a respeito dos atos administrativos, em especial acerca de sua invalidação ou anulação e da convalidação.

No âmbito federal, a Lei $n^{\circ}$ 9.784/99 traz expressa regulamentação acerca da matéria, bem como, nas esferas estaduais, exemplificativamente, a Lei ${ }^{\circ} 10.177 / 98$, do Estado de São Paulo, e a Lei n ${ }^{\circ} 14.184 / 02$, do Estado de Minas Gerais, se ocupam da questão.

Por outra vertente, impera observar que, em um dos múltiplos possíveis enfoques, o Direito tem a sua dinâmica lastreada nas relações travadas entre as pessoas. Desse modo, as relações devem estar sujeitas a diretrizes superiores, e não sujeitas ao talante de uma das partes ou do próprio Estado. Com isso, Toshio Mukai indica, com arrimo em outros, a existência de um princípio fundamental que rege as relações, qual seja, o princípio da segurança jurídica ${ }^{320}$.

À luz do Direito Administrativo, é de grande relevo a teoria do fato consumado, que consagra, entre outros, a boa-fé na solução de conflitos que digam respeito à nulidade, convalidação ou produção de efeitos em negócios jurídicos nulos. Roque Bredalga indica como pressupostos que servem de indicação para a verificação do fato consumado: a) a estabilidade e a segurança das relações jurídicas; b) a proteção da confiança e da boa-fé; c) a temporalidade; d) a inexistência de prejuízo ou a lesividade a terceiros ${ }^{321}$.

O princípio da segurança jurídica é indicado como um dos pressupostos para a consagração da teoria do fato consumado. Ocorre que a adoção desse preceito constitucional como solucionador de situações de duvidosa existência somente se revela adequada quando não beneficiar aquele que, de forma intencional, vale-se de meios não apropriados para ultrapassar, com vantagens, vedações legais. Nessa linha, o princípio da estabilidade ou da segurança jurídica deve ser mencionado como critério de previsibilidade

\footnotetext{
318 “Art. 29. O Município reger-se-á por lei orgânica, votada em dois turnos, com o interstício mínimo de dez dias, aprovada por dois terços dos membros da Câmara Municipal, que a promulgará, atendidos os princípios estabelecidos nesta Constituição, na Constituição do respectivo Estado e os seguintes preceitos...”.

319 “Art. 32. O Distrito Federal, vedada sua divisão em Municípios, reger-se-á por lei orgânica, votada em dois turnos com interstício mínimo de dez dias, e aprovada por dois terços da Câmara Legislativa, que a promulgará, atendidos os princípios estabelecidos nesta Constituição".

${ }^{320}$ MUKAI, Toshio. Da segurança jurídica: direito adquirido nas relações contratuais. Revista de Direito Administrativo. Volume 99 - janeiro/março 1995. Editora Renovar, p. 71.

${ }^{321}$ BREDALGA, Roque. Fato consumado:pressupostos. Direito \& Justiça. REVISTA DA FACULDADE DE DIREITO DA PUCRS. Volume 19 - Ano XX - 1998, p. 32.
} 
da ação estatal nas soluções de conflitos, mas de forma excepcional ${ }^{322}$. O caráter excepcional do emprego da segurança jurídica decorre da necessidade de sua harmonização com os demais pressupostos necessários à incidência da teoria do fato consumado, bem como do aparente conflito que existe com o princípio da legalidade, tendo em vista a nulidade que se apresenta ${ }^{323}$.

A proteção da confiança e da boa-fé está ligada diretamente ao pressuposto enfrentado no parágrafo precedente. Não é sem propósito que esse pressuposto é destacado, pois ele decorre, principalmente, da necessidade de preservação do tráfego jurídico e da necessidade de se posicionarem o Estado e os cidadãos como colaboradores na concretização de direitos, o que eleva a boa-fé à confiança jurídica e dá contornos menos rígidos ao princípio da legalidade. Registra Roque Bredalga que a doutrina e a jurisprudência, paulatinamente, deixaram de lado o rigor absoluto da legalidade, próprio dos atos administrativos, e foram consagrando a ideia de proteção da boa-fé e da confiança $^{324}$.

O passar do tempo é decisivo em diversos fatos jurídicos e, ainda, como um dos pressupostos basilares para a incidência da teoria do fato consumado com a irreversibilidade de situações fáticas ${ }^{325}$. Decorre a força do fator tempo da marcha avante da vida e do convívio social, de maneira que não se pode parar o relógio da vida,

\footnotetext{
322 BREDALGA, Roque. Fato consumado:pressupostos. Direito \& Justiça. REVISTA DA FACULDADE DE DIREITO DA PUCRS. Volume 19 - Ano XX - 1998, p. 34.

${ }^{323}$ Juarez Fretas destaca “...parece claro - em que pese a ausência de disposição legal expressa no sistema brasileiro - que o princípio da confiança ou da boa-fé estatui o poder-dever, em casos de longo curso temporal, de não anular, senão que de sanar ou convalidar determinados atos inquinados de vícios formais, no justo resguardo da própria estabilidade das relações jurídicas. Convém reiterar que semelhante entendimento só merece guarida quando, na situação concreta, restar manifestamente necessária a mantença do ato por respeito ao princípio da segurança ou da boa-fé, em situações marcadas por uma nota de excepcionalidade". In: FREITAS, Juarez. A anulação dos atos administrativos em face do princípio da boafé. Boletim de Direito Administrativo. Ano XI, n. ${ }^{\circ}$ 2, fevereiro, 1995, p. 96.

${ }_{324}^{324}$ BREDALGA, op. cit., p. 38.

325 "A necessidade de estabilizar as situações nas relações entre o administrado e a Administração está umbilicalmente ligado ao transcurso do tempo, que possui o escopo de imutabilizar a relação jurídica construída, mesmo que ela possua no seu nascimento o "pecado original".

Nenhuma dúvida existe que as relações anteriormente e totalmente consumadas são inatingíveis, quer pela mudança de interpretação, quer pela impossibilidade da nova norma jurídica retroagir para alcançar a situação já sepultada pelo tempo.

(...)

Dúvidas, portanto, não pairam que a estabilidade do tempo consuma a situação fática no direito administrativo, adquirindo a segurança de que a sua situação individual não sofrerá constantes revisões por parte da Administração". In: MATTOS, Mauro Roberto Gomes de. Princípio do fato consumado no direito administrativo. Revista de Direito Administrativo. 220. I-IV; I-429, abr/jun. Rio de Janeiro, 2000, p. 198.
} 
porquanto é uma constância em movimento ${ }^{326}$. De certo, cuida-se de mais um pressuposto atrelado à segurança jurídica, uma vez que se conspiraria contra o preceito constitucional a possibilidade de se poderem modificar situações consolidadas mesmo após o decurso de muitos anos.

Com isso, o passar do tempo milita em favor da manutenção das relações jurídicas estabelecidas, mesmo que o tiverem sido de maneira irregular e sem a observância dos pressupostos de validade do negócio jurídico, o que indica de modo irrefutável o tempo como pressuposto da teoria do fato consumado ${ }^{327}$.

Dúvidas podem surgir no que se refere ao prazo ou o tempo necessário ao preenchimento do pressuposto em relevo. Segundo o art. 54 da Lei $n^{\circ}$ 9.784/99, o tempo necessário é de cinco anos, que, uma vez transcorridos, obstam que a Administração anule os atos administrativos, salvo comprovação de má-fé, hipótese que dá ensejo à anulação independentemente do passar dos anos, o que pode suscitar dúvidas a respeito de sua constitucionalidade $^{328}$. Outra questão atrelada ao tempo diz respeito à natureza do prazo de anulação, se prescricional ou decadencial. No âmbito federal, o referido art. 54 da Lei $\mathrm{n}^{\circ}$ 9.784/99 estabeleceu o dever de a própria Administração anular seus atos, vale destacar, sem a atuação dos órgãos do Estado responsáveis pela aplicação do Direito em casos de litígio - Judiciário. Decerto, é imposto aos entes públicos federais, o exercício da autotutela $^{329}$, o dever de anular os próprios atos que não estejam de acordo com as normas jurídicas. Cuida-se de imposição legal para que a Administração Pública, por meio de um segundo ato administrativo, independentemente da aquiescência do beneficiário, anule o primitivo ato administrativo. Trata-se, desse modo, de situação de sujeição do outro sujeito

\footnotetext{
${ }^{326}$ BREDALGA, Roque. Fato consumado:pressupostos. Direito \& Justiça. REVISTA DA FACULDADE DE DIREITO DA PUCRS. Volume 19 - Ano XX - 1998, pp. 32-33.

${ }^{327}$ Registra Juarez Freitas que "de tal modo, sou pelo entendimento de que, entre nós, dominará, sim, a imprescritibilidade da decretação de nulidade apenas quando se verificar a hipótese de que os atos administrativos tenham sido praticados viciadamente em conluio com o fraudulento beneficiário de má-fé, ou seja, quando a violação se mostrar antinômica inclusive em face do princípio da proteção da confiança ou quando, por não ter passado largo período, nada justificar, nem mesmo a boa-fé, a mantença do ato viciado por ilegalidade. Dito sinteticamente, em não havendo boa-fé cumulada com longo tempo, a declaração de nulidade do ato administrativo, com eficácia ex tunc, é imperativa a qualquer tempo". In: FREITAS, Juarez. A anulação dos atos administrativos em face do princípio da boa-fé. Boletim de Direito Administrativo. Ano XI, n. ${ }^{\circ}$ 2, fevereiro, 1995 , p. 97.

${ }^{328}$ O suposto conflito com a Constituição repousaria na possibilidade de perpétua anulação dos atos administrativos, possibilidade que militaria em desfavor do princípio da segurança jurídica.

${ }^{329}$ Acompanhando as lições de Maria Sylvia Zanella Di Pietro "enquanto pela tutela a Administração exerce o controle sobre outra pessoa jurídica por ela mesma instituída, pela autotutela o controle se exerce sobre os próprios atos, com a possibilidade de anular os ilegais e revogar os inconvenientes e inoportunos, independentemente de recurso ao Poder Juciário" In: DI PIETRO, Maria Sylvia Zanella. Direito Administrativo. 17.ed. São Paulo: Atlas, 2004, p. 73.
} 
da relação jurídica, o que indica a natureza decadencial do prazo em relevo. Em conclusão, cuidando-se de direito que gera a sujeição da parte contrária, está-se diante de prazo decadencial, ao passo que a existência de direitos subjetivos acarretaria a verificação de prazo prescricional ${ }^{330}$, pois nessa hipótese existira a possibilidade de insurgência.

Veja-se que a incidência da teoria do fato consumado clama pela inexistência de prejuízo ou de lesão a terceiros. A compreensão do termo "terceiro" não se confunde, na hipótese, com a significação processual que lhe é dada, isto é, como aquele que não participa da relação processual ou como aquele que não participa da relação de direito material. Nos lindes da teoria do fato consumado, o termo é empregado de forma mais abrangente, muito em razão de sua especial aplicação às relações com a Administração Pública, que tutela bens e interesses públicos, o que acaba por considerar como terceiros todas as pessoas que, de uma forma ou outra, estão subordinados ou em colaboração com os entes públicos. Frise-se que o exercício da administração pública tem natureza e fins que se destinam a defesa, conservação e aprimoramento dos bens, serviços e interesses da coletividade, em razão do que o conceito de terceiro abrange toda a sociedade ${ }^{331}$.

Assim, a teoria do fato consumado pretende a preservação de efeitos produzidos em atos nulos e, mais além, a convalidação desses atos.

Em conclusão, o Direito Administrativo permite o restabelecimento da legalidade por meio da invalidação, da convalidação e, sob certo aspecto, com a utilização da teoria do fato consumado. Ademais, essa especialidade do Direito não pretende, em todos os casos, a fulminação dos efeitos produzidos, sendo clara, sob as vertentes doutrinária e normativa, a proteção de terceiros de boa-fé e a proibição do enriquecimento sem causa.

\footnotetext{
${ }^{330}$ Juarez Freitas, em texto anterior à Lei n. ${ }^{\circ}$ 9.784/99, observa que "por outro lado, e em contrapartida, é de se ter claro que se advoga a temperada incidência do Dec. $n^{\circ} 20.910 / 32$, art. $1^{\circ}$, no que diz com a prescrição ali prevista, nas hipóteses em que a regras da prescritibilidade posicionar-se em rota de colisão frontal com as exigências conjugadas do princípio da moralidade e da legalidade. Em outras palavras, nas situações consumadas e, de modo parcimonioso, é de ver como inocorrente a prescritibilidade, sempre que assim o exigir o princípio da boa-fé, naturalmente apenas em razão de atos anuláveis. No mesmo diapasão, é de trazer a lume o exemplo da Lei $\mathrm{n}^{\circ} 8.112 / 90$, a qual, após tratar da prescrição do direito de petição, estatui corretamente que a Administração deverá rever, a qualquer tempo, os seus atos, quando eivados de ilegalidade, a qual deve ser tomada no seu sentido mais amplo, para abranger - não excluir, como se poderia cogitar numa leitura de plano - o princípio da segurança das relações jurídicas. Trata-se de mais um robusto exemplo de que o legislador brasileiro agasalhou, de modo algo assistemático, a imprescritibilidade, exceto em relação aos atos administrativos que se revelarem eivados de má-fé na sua originária formação, ou que, mesmo quando praticados com suposta boa-fé do beneficiário, não tenham sido curados pelo tempo". In: FREITAS, Juarez. A anulação dos atos administrativos em face do princípio da boa-fé. Ano XI, n. ${ }^{\circ} 2$, fevereiro, 1995, p. 98.

331 BREDALGA, Roque. Fato consumado:pressupostos. Direito \& Justiça. REVISTA DA FACULDADE DE DIREITO DA PUCRS. Volume 19 - Ano XX - 1998, p. 41.
} 


\section{Pontos de aproximação entre os enfoques trabalhista e administrativista.}

Nos campos do Direito Civil, as nulidades são insanáveis, de maneira que os negócios jurídicos que padecem de vício de validade não são passíveis de confirmação nem mesmo se convalescem pelo decurso do tempo ${ }^{332}$, aceitando o Direito Comum, unicamente, a subsistência do negócio nulo quando contiver os requisitos de outro e o fim a que visavam as partes permitir supor que o teriam querido, se tivessem previsto a nulidade ${ }^{333}$.

Por sua vez, o Direito do Trabalho não possui normas a esse respeito, isto é, normas que obstem a confirmação do negócio jurídico ou que ele convalesça com o tempo, o que permite, ao menos, inicialmente, a ampla produção de efeitos em contratos de emprego nulos. Não se ignora a existência de cláusula de retenção na CLT, que possibilita a aplicação de normas do Direito Comum nas hipóteses de omissão do texto obreiro, desde que a lacuna seja acompanhada de compatibilidade das normas integradoras com a principiologia própria do Direito do Trabalho ${ }^{334}$.

Pelo que já foi dito, as normas que tratam das nulidades no Direito Comum não se mostram compatíveis com o princípio da continuidade da relação de emprego e com o princípio protetor, o que não representa, por certo, que todas as hipóteses de nulidade da seara trabalhista devam ser convalidadas. Já no Direito Administrativo, apreciado com os olhos voltados à legislação federal, há expressa autorização de convalidação de atos administrativos nulos, desde que não ocorra lesão ao interesse público ou prejuízo a terceiros e que se cuide de defeito sanável ${ }^{335}$.

\footnotetext{
332 "Código Civil. Art. 169. O negócio jurídico nulo não é suscetível de confirmação, nem convalece pelo decurso do tempo".

333 "Código Civil. Art. 170. Se, porém, o negócio nulo contiver os requisitos de outro, subsistirá este quando o fim a que visavam as partes permitir supor que o teriam querido, se houvessem previsto a nulidade".

334 "CLT. Art. $\mathbf{8}^{\mathbf{0}}$ As autoridades administrativas e a Justiça do Trabalho, na falta de disposições legais ou contratuais, decidirão, conforme o caso, pela jurisprudência, por analogia, por equidade e outros princípios e normas gerais do direito, principalmente do direito do trabalho e, ainda, de acordo com os usos e costumes, o direito comparado, mas sempre de maneira que nenhum interesse de classe ou particular prevaleça sobre o interesse público.

Parágrafo único. O direito comum será fonte subsidiária do direito do trabalho, naquilo em que não for incompatível com os princípios fundamentais deste".

335 "Lei n. ${ }^{\circ}$ 9.784/99. Art. 55. Em decisão na qual se evidencie não acarretarem lesão ao interesse público nem prejuízo a terceiros, os atos que apresentarem defeitos sanáveis poderão ser convalidados pela própria Administração".
} 
Contudo, não há no Direito ramo que contemple solução diversa da nulidade para a não observância dos pressupostos de validade. Porém, o cotejo das distintas searas indica que o Direito Civil possui regime mais severo quanto às nulidades do que o Direito do Trabalho e o Direito Administrativo. Todavia, as normas mais tênues das duas últimas especialidades não representam que a ausência de concurso público possa ser superada de modo a ser mantido intacto o negócio nulo. Isso porque é forte o apelo pragmático da declaração de nulidade, mesmo porque a baixa produção de efeitos desestimularia a ocorrência de violações ${ }^{336}$, o que seria obtido com maior êxito se os administradores públicos passassem a responder por contratações sem concurso público que derem ocasião.

Assim, é nítida a distinção entre Direito Civil, Direito Administrativo e Direito Trabalhista, o que inclusive já foi objeto de considerações doutrinárias, como as realizadas por Mauro Roberto Gomes de Mattos, ao afirmar que se no campo do Direito Privado o nulo jamais pode ser sanado, na esfera do Direito Público a questão é tratada com menor rigor formal em razão da proeminência do interesse público e da segurança das relações dos administrados com a Administração Pública ${ }^{337}$, o que acresce um pouco mais o interesse em se explicitarem as normas jurídicas em conflito.

\section{O conflito.}

A nulidade de um ato jurídico, nomeadamente daqueles que possuem natureza de negócio jurídico, é marcada, diversas vezes, por preceitos aparentemente antagônicos. Buscou-se com o desenvolvimento dos dizeres pretéritos indicar os preceitos que regem a questão, de modo que se pode indicar que o conflito repousa na previsão constitucional que impõe a nulidade da contratação ao arrepio do concurso público diante da irretroatividade da decretação da nulidade no Direito do Trabalho. Esse conflito, em termos mais abstratos e com o olhar constitucional, poderia ser visualizado como o confronto do valor social do trabalho e dos princípios da igualdade, impessoalidade, eficiência e moralidade pública, porquanto, de certo modo, amparam as proposições aparentemente em conflito ${ }^{338} 339$.

\footnotetext{
${ }^{336}$ SILVA, Homero Batista Mateus da. Curso de direito do trabalho aplicado, vol. 6: contrato de trabalho. Rio de Janeiro: Elsevier, 2009, p. 25.

${ }^{337}$ MATTOS, Mauro Roberto Gomes de. Princípio do fato consumado no direito administrativo. Revista de Direito Administrativo. 220. I-IV; I-429, abr/jun. Rio de Janeiro, 2000, p. 195.

338 Juarez Freitas indica que a anulação do ato administrativo, em especial aquele que gera direitos, é marcado, diversas vezes, por dois princípios aparentemente antagônicos. Encontramos de em um lado o princípio da legalidade que, em certa interpretação, exige a anulação dos negócios jurídicos viciados; em
} 
É importante ressaltar que os valores em aparente colisão possuem idêntica hierarquia, o que lhes impõe o mesmo tratamento jurídico, por possuírem o mesmo fundamento de validade, que é justamente o assento constitucional, conjunto de normas que deve ser visto como uma unidade para que se preserve a integralidade do sistema ${ }^{340}$. Logo, ao menos como ponto de partida, as proposições se encontram em mesmo plano, de modo que nenhuma delas busca fundamento na outra.

Inegável, por outro lado, que as normas em destaque possuem a natureza jurídica de princípios. De tal modo, são mandamentos de otimização, normas prima facie, porquanto a realização do garantido pela proposição varia segundo as peculiaridades do caso, não ocorrendo, como se dá com as normas do tipo regra, em que a incidência de seus preceitos ocorre de modo cabal ou se excluem com a mesma completude, em verdadeiro cenário de tudo ou nada ${ }^{341}$. Depreende-se, com isso, que as normas apresentadas não consagram soluções prontas para eventuais conflitos, o que revela seus conteúdos variáveis e amoldáveis à melhor solução.

Ora, diante dos contornos do conflito apresentado, pululam questionamentos acerca dos meios utilizáveis na sua resolução, bem como sobre os efeitos que podem decorrer do negócio jurídico nulo, o que se examinará nos tópicos vindouros.

\section{Possíveis soluções. Meios de aplicação das normas jurídicas.}

A solução de conflitos efetivos entre bens juridicamente tutelados depende, não raras vezes, de sua submissão ao Poder Judiciário, órgão do Estado responsável por decidir os litígios de modo definitivo. Nesse contexto, a atuação do Estado-juiz consiste, basicamente, na identificação do direito incidente e na revelação de seu entendimento,

outro lado, encontramos o princípio da proteção da confiança, que exige a consideração da boa-fé do destinatário do ato administrativo que lhe concede direitos. In: FREITAS, Juarez. A anulação dos atos administrativos em face do princípio da boa-fé. Boletim de Direito Administrativo. Ano XI, n. ${ }^{o} 2$, fevereiro, 1995, p. 96.

${ }^{339}$ Poderia-se, ainda, dizer que o problema que se apresenta é o exercício de funções de fato por sujeito de boa-fé, que é chamado por Fernando Henrique Mendes de Almeida como funcionário de fato escusável, porquanto exerce função ao arrepio da legislação própria, mas o faz de boa-fé. In: ALMEIDA, Fernando Henrique Mendes de. Contribuição ao estudo da função de fato. São Paulo: Saraiva, 1957. p. 74.

${ }^{340}$ BARROSO, Luís Roberto. Interpretação e aplicação da Constituição: fundamentos de uma dogmática constitucional transformadora. 7. ed. rev. São Paulo: Saraiva, 2009, p. 202.

${ }^{341}$ SILVA, Virgílio Afonso da. Direitos Fundamentais - Conteúdo Essencial, Restrições e Eficácia. 2. ed. Malheiros, 2010, p. 45. 
atividade que recebe o nome de interpretação. Mas não é só, também cabe ao Estado-juiz a aplicação da norma interpretada ao caso apresentado.

Ocorre que nem todas as normas jurídicas são aplicadas da mesma maneira, porquanto a diversidade de estruturas, em regras e princípios, exige o desenvolvimento de meios diversos que atendam às peculiaridades de cada uma das espécies de norma.

Resta verificar quais são esses meios.

\section{Subsunção.}

Entende-se por subsunção o meio de aplicação de regras jurídicas, vale destacar, de normas que possuem o campo de incidência bem definido e, uma vez verificados seus pressupostos fáticos, incidem de modo completo. Partindo-se dos fatos apresentados, verificam-se as proposições que os regem, e se revela a norma a ser aplicada, de maneira que a coexistência de regras que abranjam o mesmo fato é resolvida com regras de direito intertemporal, como a revogação, ou com o estabelecimento de restrições pelo próprio legislador $^{342}$.

Tendo em vista que o valor social do trabalho e os princípios da igualdade, impessoalidade, eficiência e moralidade não têm seu alcance determinado de início, o emprego da subsunção na solução do conflito não se revela apropriado. Mesmo porque não há nenhuma regra na $\mathrm{CR}$ que compatibilize o conflito em apreço, o que destaca que o legislador não apresentou solução prévia, repousando sobre os aplicadores do Direito o enfrentamento da questão.

Assim, rechaça-se a utilização da subsunção, especialmente por não se tratar de conflito entre regras.

\section{Ponderação.}

A ideia de ponderação surge nas hipóteses em que há a necessidade de se encontrar a solução de casos de tensão entre bens juridicamente protegidos por normas

\footnotetext{
${ }^{342}$ SILVA, Virgílio Afonso da. Direitos Fundamentais - Conteúdo Essencial, Restrições e Eficácia. 2. ed.
} Malheiros, 2010, p. 52. 
com estrutura de princípio e com idêntica hierarquia, cujo campo de incidência se mostra mais fluído. Diante da multiplicidade de valores existentes na sociedade pátria, impõe-se uma análise cuidadosa da hipótese, bem como uma boa fundamentação para a solução do conflito $^{343}$.

Nesse sentido, a ponderação presta-se à verificação de critérios para a solução de conflitos, o que não representa, de modo nenhum, um modelo que propõe uma justiça casuística. Não se corre esse risco em virtude da necessidade de cuidadosa identificação dos bens em conflito e, ainda, da justificação da escolha feita. Desse modo, o aplicador do direito deve identificar quais são as normas jurídicas que regulam os interesses em conflitos, precisando em que medida a área ou esfera de um direto se sobrepõe à do outro e, ainda, do espaço que resta aos bens jurídicos para além da zona de sobreposição ${ }^{344}$.

O valor social do trabalho, princípio que subsidia a irretroatividade da decretação da nulidade trabalhista, tem assento no art. $1^{\circ}$, IV, da CR. Sua esfera de atuação está em impossibilitar que o trabalho receba, quer pelo legislador, quer por particulares, tratamento que o equipare a qualquer mercadoria ou tratamento que não seja compatível com a dignidade da pessoa humana, preceitos já enfrentados por ocasião da discussão do objeto do negócio jurídico de emprego.

Por sua vez, os princípios da impessoalidade e da moralidade, referenciais abstratos do concurso público, são explicitados pelo art. 37, caput, da CR. São princípios que pretendem a atuação da Administração Pública sem favorecimentos pessoais, mas, sim, com foco no interesse público, e sempre de modo probo, o que acaba por repercutir, de certo modo, na igualdade de acesso aos empregos públicos.

Depreende-se dos parágrafos anteriores que as esferas das normas não coincidem, nem mesmo conflitam. Em verdade, podem ser visualizadas como complementares, de modo que a atuação conjunta, vale dizer, interpretações e aplicações harmônicas, é possível e necessária, o que acaba por afastar a ponderação, compreendida nesse ponto como prevalência axiológica de um princípio sobre outro em determinada hipótese $\mathrm{e}^{345}$, e por sugerir a harmonização dos princípios postos em observância para superar a

${ }^{343}$ CANOTILHO, José Joaquim Gomes. Direito Constitucional e Teoria da Constituição. $5^{\mathrm{a}}$ ed. Almedina, p. 1221.

${ }^{344}$ Ibidem, p. 1222.

${ }^{345}$ Ibidem, p. 1225. 
necessidade de resolver a questão da produção de efeitos em contrato de emprego nulo celebrados com a Administração Pública.

Em suma, a distinção do âmbito de incidência das normas esgota o conflito, pois, em realidade, ele não ocorre, uma vez que as normas não se posicionam de modo a ocasioná-lo ${ }^{346}$.

\section{Harmonização de princípios. Extensão de efeitos.}

Como alternativa à subsunção e à ponderação, encontramos a harmonização de princípios, que pode ser compreendida como uma contemporização ou transação entre eles, de modo a garantir, na hipótese concreta, a aplicação conjunta das normas aparentemente em conflito ${ }^{347}$. Desse modo, não se deve confundir a ponderação propriamente dita com a harmonização de princípios, pois naquela há a identificação da prevalência de um deles como meio de solução do conflito, ao passo que nesta há a atuação conjunta. Assim, o ponto de equilíbrio entre os princípios não poderá representar a supremacia de qualquer deles sobre o outro, mesmo que transitoriamente para a solução de determinado caso.

A harmonização das normas em conflito passa, necessariamente, pela identificação dos efeitos do negócio jurídico que devem ser conferidos ou preservados. Não é sem razão que os efeitos indicam o ponto de harmonia, isso decorre justamente da necessidade de se conciliarem a irretroatividade da nulidade trabalhista, fundamentada no valor social do trabalho, e a exigência de concurso público, que se ampara nos princípios da impessoalidade e da moralidade, o que é aferido por meio da identificação dos direitos concedidos ou mantidos, pois são eles que indicam a repercussão do nulo nas relações sociais.

A esse respeito, mostram-se relevantes os dizeres de Celso Antônio Bandeira de Mello, segundo o qual, negócio jurídico nulo não deveria ocorrer, por isso não deveria produzir efeitos, mas, de fato, são celebrados e produzem efeitos e podem continuar a produzi-los até que a invalidade seja descoberta e declarada ${ }^{348}$. Nesse contexto, constitui

\footnotetext{
${ }^{346}$ CANOTILHO, José Joaquim Gomes. Direito Constitucional e Teoria da Constituição. $5^{\text {a }}$ ed. Almedina, p.1223.

${ }^{347}$ Ibidem, p. 1225.

${ }^{348}$ MELLO, Celso Antônio Bandeira de. Curso de Direito Administrativo. 22.ed. São Paulo: Malheiros, 2007, p. 457.
} 
equívoco afirmar que os negócios jurídicos nulos não produzem efeitos, pois, valendo-nos, uma vez mais, dos dizeres do doutrinador em relevo, podemos afirmar que ninguém pretenderia a decretação do nulo se não fora para fulminar os efeitos já produzidos ou na iminência de se produzirem ${ }^{349}$.

$\mathrm{Na}$ esteira desses ensinamentos, a produção de efeitos é inevitável e as dificuldades surgem com a necessidade de se determinarem os direitos que podem ser produzidos ou que devam ser preservados, para que ocorra a harmonização das normas em conflito. Com o advento da Constituição de 1988, formaram-se algumas linhas de entendimento a respeito das consequências jurídicas para os casos de ausência de concurso público, isto é, sobre quais direitos deveriam ser oferecidos àqueles que, sem a observância dos reclames normativos, exerceram, de fato, atribuições na Administração Pública - os chamados funcionários de fato $^{350}$. Diversas soluções podem ser apresentadas, partindo-se da ausência de efeitos, passando pela concessão restrita, e findando-se com a concessão ampla.

Note-se, por relevante, que a divisão que se faz é entre os que defendem a ampla concessão de direitos e os que sustentam a restrição de direitos. Antes de se analisarem os diferentes entendimentos, devem-se separar duas consequências diversas no que se refere à violação do art. 37, II: a manutenção de vínculo com a Administração e os direitos que podem ser conferidos ao trabalhador ${ }^{351}$. Como já se realçou em linhas pretéritas, a ausência de concurso público implica a nulidade do ato (art. $37, \S 2^{\circ}$ ) e, consequentemente, afasta a possibilidade de manutenção de vínculo de emprego. Essa situação não se confunde com a concessão de direitos, que pode ocorrer mesmo com a cessão do vínculo por força de disposição constitucional, desde que, é claro, assim se entenda.

Vejamos.

Registra Maurício Godinho Delgado a existência de entendimento que nega a produção de qualquer efeito próprio do negócio jurídico, especificamente em razão de sua nulidade. Apresenta, também, uma variante um pouco mais tênue, adotada pelo TST, que

\footnotetext{
${ }^{349}$ MELLO, Celso Antônio Bandeira de. Curso de Direito Administrativo. 22.ed. São Paulo: Malheiros, 2007, p. 458.

350 ALMEIDA, Fernando Henrique Mendes de. Contribuição ao estudo da função de fato. São Paulo: Saraiva, 1957, p. 15.

${ }^{351}$ MAGALHÃES, Gustavo Alexandre; MAIOR, Jorge Luiz Souto. Efeitos da nulidade na contratação de servidores públicos. in O Servidor público e a Justiça do Trabalho: homenagem ao Ministro Ronaldo José Lopes Leal. José Ronald Cavalcante Soares, coordenador. São Paulo: LTr, 2005, p. 123.
} 
impõe o pagamento exclusivamente das horas trabalhadas e dos depósitos do Fundo de Garantia do Tempo de Serviço - FGTS ${ }^{352}$.

Mais progressista, há entendimento que insiste na plena e irrestrita aplicação da teoria trabalhista a respeito das nulidades, o que implicaria, inclusive, o pagamento de parcelas inerentes à dispensa injusta. Apesar de não fazer menção ao aspecto trabalhista, Celso Antônio Bandeira de Mello, ao aludir a concursos anulados, defende a ampla produção de efeitos jurídicos, negando, expressamente, a restituição do que o trabalhador recebeu ${ }^{353}$, o que evidencia postura favorável à ampla concessão de direitos.

Com conclusões semelhantes às destacadas no parágrafo antecedente, porém amparada em fundamentos com os quais não concordamos por razões já explicitadas, revela-se a corrente que pretende a indenização do trabalhador pelo valor equivalente ao de seus direitos negligenciados no curso do negócio jurídico nulo, tendo em vista a proibição do enriquecimento ilícito do empregador, posição, inclusive, adotada por Délio Maranhão ${ }^{354}$. Atente-se que essa linha não defende, propriamente, a produção de efeitos particulares do negócio jurídico trabalhista, pretende, simplesmente, a recomposição ao estado anterior ao da celebração do inválido. Pode ser apontado como defensor desse entendimento, entre outros, Ari Pedro Lorenzetti ${ }^{355}$.

Por fim, há concepção que indica como solução harmonizadora da questão o pagamento de todas as verbas devidas no curso da relação de emprego, sem que exista, contudo, o direito a verbas próprias à dispensa injusta, quais sejam, aviso-prévio, multa de $40 \%$ sobre FGTS e seguro-desemprego, tendo em vista que o contrato terá cessação por imposição constitucional ${ }^{356}$, e não por arbítrio do empregador.

Todas as soluções apresentadas concordam com a não manutenção do vínculo, porquanto a nulidade do negócio jurídico que lhe dá causa clama pela cessação da relação, o que se retira da redação do art. $37, \S 2^{\circ}$, da CR. Contudo, divergem no restante, como visto. As concepções que negam a produção de efeitos ou que pregam o pagamento de restritíssimas parcelas prestigiam os preceitos administrativistas em detrimento dos

\footnotetext{
${ }^{352}$ DELGADO, Mauricio Godinho. Curso de direito do trabalho. 10. ed. São Paulo: LTr, 2011, p. 503.

353 MELlO, Celso Antônio Bandeira de. Curso de Direito Administrativo. 22.ed. São Paulo: Malheiros, 2007 , p. 459.

354 SÜSSEKIND, Arnaldo. Institutições de direito do trabalho. Volume I. 22. ed. atual. Por Arnaldo Süssekind e João de Lima Teixeira Filho. São Paulo: LTr, 2005, p. 253.

${ }_{355}^{35}$ LORENZETTI, Ari Pedro. As nulidades o direito do trabalho. 2.ed. São Paulo: LTr, 2010, p. 384.

${ }^{356}$ DELGADO, op. cit., p. 503.
} 
trabalhistas ${ }^{357}$. Sob outro olhar, os entendimentos favoráveis à ampla concessão de direitos ou ao pagamento de indenização pelo valor a eles equivalente fazem o caminho inverso, ao privilegiar os preceitos trabalhistas. Por derradeiro, o entendimento que propõe o pagamento somente das parcelas devidas no curso do contrato de emprego, sem abranger as verbas rescisórias ${ }^{358}$, é o que, entre os ofertados, a nosso ver, melhor soluciona o conflito.

Em conformidade com o exposto, o último entendimento revela-se valoroso por impor o pagamento das verbas devidas no curso da relação de emprego, o que observa a irretroatividade das nulidades trabalhistas, com o término do vínculo, mas sem que ocorra o pagamento de verbas específicas da dispensa por iniciativa patronal, preservando, dessa maneira, as regras próprias do concurso público.

Não obstante, essa solução tem o inconveniente de não distinguir trabalhadores de boa-fé dos obreiros de má-fé, o que, a nosso ver, é imperioso para que não se esvazie o comando constitucional que impõe o concurso público. Com isso, entendemos que a harmonização das normas em conflito depende, além da cessação do vínculo, também da extensão ou da concessão de direitos apenas aos trabalhadores de boa-fé. Vê-se, desse modo que um conflito pode ser resolvido de diversas maneiras 359360361 , chegando-se à mesma solução ou a soluções diversas, e optamos pela harmonização de princípios, diante e em virtude da boa-fé do trabalhador, como uma das manifestações dessa importante fonte

\footnotetext{
${ }^{357}$ BRANDAO, Claudio Mascarenhas. A exigência de concurso publico após a Constituição de 1988. LTr: revista legislação do trabalho. São Paulo. v.58. n.11. p.1320-3. nov. 1994, p. 1320-1322.

${ }^{358}$ De outro bordo, encontramos os direitos ou parcelas típicas do término do contrato de emprego. Não há rigor científico na utilização da expressão "verbas rescisórias" para a generalidade das espécies de término do contrato, uma vez que rescisão é figura própria da cessação do contrato de emprego para os casos de nulidade, como a hipótese do presente trabalho. Por sua vez, reserva-se o termo resilição à renúncia vazia ou não motivada do contrato e o termo resolução para os casos em que a cessação do contrato se ampara em ato faltoso de qualquer dos sujeitos da relação de emprego. De todo modo, utilizaremos a expressão "verbas rescisórias" para nos referirmos ao conjunto de prestações decorrentes do término do contrato de emprego, independentemente de sua causa. Ainda, nem todas as parcelas elencadas no art. $7^{\circ}$ da Constituição que devem ser pagas verbas por ocasião do término do contrato são devidas em todas as hipóteses, algumas delas são devidas apenas no caso de término do contrato por iniciativa do empregador (resilição) ou de falta por ele praticada (rescisão indireta - hipótese de resolução).

${ }^{359}$ LOUSSOUARN. M. Ivon. La buena fe. in Tratado de la Buena Fe en el Derecho. Marcos M. Córdoba (Diretor) - 1. ed. v.2. Buenos Aires: La Ley, 2004, p. 6.

360 LIMA, Francisco Gerson Marques de. Contratação de servidor público sem o certame exigido constitucionalmente - efeitos. IOB-Repertório de Jurisprudência: trabalhista e Previdenciário. São Paulo. n.21. p.365-360. nov. 1994, p. 361.

${ }^{361}$ GIORDANI, Francisco A. de Motta Peixoto. A contratação de servidor público sem concurso x princípio da dignidade da pessoa humana: colisão de direitos? Outro enfoque; conseqüências. Revista da AJURIS. Porto Alegre. v.29. n.87. p.67-76. set. 2002.
} 
do Direito ${ }^{362}$, o que inclusive já foi proposto por Gustavo Alexandre Magalhães e Jorge Luiz Souto Maior ${ }^{363}$ e será enfrentado em capítulo apartado.

Em reforço à sua utilização, Nelson Rosenvald afirma que a boa-fé concretiza o princípio da solidariedade social, pois direciona o negócio jurídico à sua função social, e densifica o princípio da dignidade ${ }^{364}$. Essa identificação com princípios de relevo na atual Constituição afirmam, sem dúvida, que a boa-fé deve ocupar a fundamentação das decisões políticas e jurídicas, colaborando sobremaneira com a atividade do aplicador do direito, com maior razão nos casos em que se faz necessária a harmonização de princípios, porquanto impõe a atuação conjunta de normas jurídicas na busca de uma solução adequada aos casos apresentados.

Antes disso, a distinção entre boa e má-fé fica claríssima nos dizeres de Hugo Nigro Mazzilli, que, ao questionar-se a respeito da necessidade ou não de reposição ao erário do dinheiro pago aos trabalhadores ilegalmente contratados acaba por concluir que:

\begin{abstract}
“... o prestador do serviço, o fornecedor ou executor da obra serão indenizados, na medida em que tiverem agido de boa-fé, (...) não se está pretendendo que a eventual responsabilização patrimonial se volte obrigatoriamente contra os contratados. Se na instrução judicial ficar apurado que as ilegalidades cometidas em nada lhes são imputáveis, a responsabilidade deve ser carreada tão somente aos administradores que contratam ilegalmente, pois eles sim é que devem arcar com os custos que o Erário teve com as contratações sem o concurso público que eles indevidamente dispensaram"365.
\end{abstract}

\footnotetext{
${ }^{362}$ Extrai-s Vicente Ráo que "certas legislações incluem entre as fontes subsidiárias do direito, além dos costumes, os princípios gerais de direito. Assim, o Código Civil brasileiro dispõe: "Quando a lei for omissa, o juiz decidirá o caso de acordo com a analogia, os costumes e os princípios gerais de direito" (Introd., art. 4. ${ }^{\circ}$ ); o Código Civil argentino prescreve: "Se não se puder resolver uma questão civil nem pelas palavras, nem pelo espírito da lei, atender-se-á aos princípios das leis análogas e se a questão permanecer duvidosa, aos princípios gerais do direito, tendo-se em conta as circunstâncias do caso" (art. 16); o Código Civil mexicano declara: "As controvérsias jurídicas de ordem civil devem resolver-se de conformidade com a letra da lei ou segundo sua interpretação jurídica. Na falta de lei, resolver-se-ão segundo os princípios gerais de direito" (art. 19); o novo Código Civil italiano estabelece: “...se uma controvérsia não pode ser decididas segundo uma disposição (legal), ter-se-ão em contas as disposições que regulam os casos semelhantes ou as matérias análogas; persistindo a dúvida, decidir-se-á segundo os princípios gerais do ordenamento jurídico do Estado" (art. 12)". In: RÁO, Vicente. O Direito e a Vida dos Direitos: Noções Gerais. Direito Positivo. Direito Objetivo. Teoria Geral do Direito Subjetivo. Análise dos Elementos que Constituem os Direitos Subjetivos. $6^{a}$.ed. Anotada e atualizada com o novo Código Civil por Ovídio Rocha Barros Sandoval. Editora Revista dos Tribunais, 2005, p. 298.

${ }^{363}$ MAGALHÃES, Gustavo Alexandre; MAIOR, Jorge Luiz Souto. Efeitos da nulidade na contratação de servidores públicos. in O Servidor público e a Justiça do Trabalho: homenagem ao Ministro Ronaldo José Lopes Leal. José Ronald Cavalcante Soares, coordenador. São Paulo: LTr, 2005, p. 125.

${ }^{364}$ ROSENVALD, Nelson. Dignidade humana e boa-fé no código civil. São Paulo: Saraiva, 2005, pp. 176 e 178.

${ }^{365}$ MAZZILLI, Hugo Nigro. Concurso público na administração. Revista dos Tribunais. São Paulo. v.84. n.716. p.37-40. jun. 1995, p. 40.
} 
Por fim, mas sem a pretensão de esgotar o tema além dos limites que verdadeiramente interessam ao objeto do presente estudo, recomendamos que a adoção dessa teoria seja acompanhada, ainda, pela efetivação da repressão da improbidade administrativa consubstanciada no inciso $\mathrm{V}$ do art. 11 da Lei $\mathrm{n}^{\circ}$ 8.429/92, mediante o ajuizamento de ações visando a punir os verdadeiros responsáveis pela contratação ao arrepio da regra constitucional que, a bem da verdade, veio para extirpar o ranço generalizado de apadrinhamento no âmbito da Administração, prática consagrada na história brasileira e presente, ainda hoje, sob a égide da Constituição Cidadã. Em outras palavras, os princípios e interesses públicos subjacentes à exigência do concurso público devem ser resguardados e/ou restaurados com a responsabilização dos administradores que, desde o início, tinham ciência e assumiram os riscos da ilegalidade que estavam praticando, e não à custa ou em detrimento do cidadão, que, sujeito a toda sorte de contingências sociais e econômicas, e, especialmente, na legítima expectativa de estar sendo contratado por entidades que deveriam ser exemplos de lisura jurídica, despende, de forma definitiva, sua força física ou intelectual em prol da Administração. 


\section{A BOA-FÉ.}

\section{Histórico da boa-fé. A origem romana.}

O estudo histórico da boa-fé, partindo-se de conceitos primitivos, é de extrema dificuldade, uma vez que remonta a períodos distantes da cultura romana, de pouca documentação e, também, de difícil reconstituição ambiental sociocultural ${ }^{366}$. Mesmo diante dessas dificuldades, especialistas como Menezes Cordeiro concordam sobre o fato de a boa-fé ser herdeira de uma noção mais vasta e antiga, mas menos precisa, a fides ${ }^{367}$.

A fides possui uma diversidade de significados: a sacra que é encontrada na Lei das XII Tábuas, ao impor sanção religiosa àquele que defraudasse a fides alheia; no culto da deusa Fides, que possuía na sua mão direita o símbolo da entrega e da lealdade; também nos poderes atribuídos ao pater e nas suas limitações. A fides-facto, despida de qualquer conotação religiosa ou moral, traz a ideia de garantia. Por último, a fides-ética que repousa a garantia de algo nas qualidades pessoais de alguém, o que emprestou coloração moral à figura, de modo que a fides ganha a figura de dever, mesmo que não recebida pelo Direito $^{368} 369$.

Francisco Amaral destaca a relevância do aspecto religioso ao afirmar que a fides era representada pela deusa Fides (fé), invocada na celebração dos negócios, que velava por seu cumprimento, castigando os faltosos e protegendo os cumpridores ${ }^{370}$. Essa concepção desenvolveu-se em duas linhas: nas relações internacionais entre estados ou cidadãos de estados diversos, quando era vista como virtude, garantia de lealdade e respeito de correção e confiança; em outro sentido, próprio das relações privadas, a fides

\footnotetext{
${ }^{366}$ CORDEIRO, António Manuel da Rocha e Menezes. Da boa fé no direito civil. Almedina, 2011, p. 53.

${ }^{367}$ RUBINSTEIN, Flávio. A bona fides como origem da boa-fé objetivo do Direito brasileiro. Revista da Faculdade de Direito USP. São Paulo. V. 99. 2004, p. 587.

${ }^{368}$ CORDEIRO, op. cit., pp. 54 a 56.

369 “O Direito Romano não elaborou um princípio jurídico da boa fé. Contudo, juridiciza a idéia de fides, objetivando-a como bona fides, que passa a servir de ponte entre os formalismo e o consensualismo na prática contratual”. In: VELASCO, Ignácio M. Podeva. A boa fé na formação dos contratos (direito romano). Revista de Direito Civil, Imobiliário, Agrário e Empresarial. Ano 16, julho-setembro/1992, p. 40.

${ }^{370}$ Inclusive o aperto de mãos teria surgido em decorrência da concepção religiosa da fides, nesse sentido professa Francisco Amaral que "tinha sua sede na palma da mão direita (Cícero. De off. 1, 7, 23)(Tito Lívio, Hist. 1, 21, 4). Por isso os contratantes davam uma aperto das mãos diretas (dextrarum porrectio) para imprimir solenidade à promessa. Desaparecido o culto à deusa Fides, ficou o aperto de mãos como sinal de confiança mútua". In: AMARAL, Francisco. A boa-fé no processo romano. Revista de Direito Civil, Imobiliário, Agrário e Empresarial. Ano 20, outubro-dezembro, 1996, p. 199.
} 
representa o valor ético-religioso constatado nas Leis das XII Tábuas, 7, $14^{371}$, que tutelava as relações de clientela ${ }^{372}$.

Essa multiplicidade de concepções conduz ao trato pragmático da fides em detrimento de construções gerais, o que traz por consequência a ausência de significado preciso no seu emprego isolado ${ }^{373} 374$. Contudo, é possível perceber, como elemento comum aos diversos matizes, que a fides é a projeção de aplicações concretas prévias ${ }^{375}$, isto é, uma construção paulatina amparada nas relações sociais existentes à época, o que revela, em grande parte, o caráter prático do Direito Romano.

Ocorre que as limitações do sistema jurídico romano, que atribuía concretamente ações em vez de reconhecer abstratamente posições jurídicas, colaborou com a passagem da fides para a fides bona e dessa para a bona fides ${ }^{376}$. Isso porque existiam apenas poucas ações $^{377}$, incapazes de atender às transformações sociais verificadas, o que fez com que a fides atingisse o que a forma não atingia, vale dizer, o protótipo da situação jurídica era protagonizado não por um direito subjetivo ou por uma posição jurídica, mas por uma ação, de modo que para os romanos havia, no campo processual, uma distinção entre os contratos normais, que eram protegidos por ações de direito estrito (stricti iuris iudicia), e os consensuais, que eram por ações de boa-fé (bonae fidei iudicia), nas quais o juiz tinha um campo de atuação e de apreciação mais amplo ${ }^{378}$.

Ao lado do aspecto processual, era importante que as partes mantivessem a palavra empenhada, de modo que houve grande desenvolvimento da fides no âmbito comercial, em que o tráfego de mercadorias e de pessoas era marcadamente informal e

371 "Se um patrono causa dano a seu cliente, que seja declarado sacer (podendo ser morto como vítima devotada aos deuses)".

372 AMARAL, Francisco. A boa-fé no processo romano. Revista de Direito Civil, Imobiliário, Agrário e Empresarial. Ano 20, outubro-dezembro, 1996, p. 1999.

${ }_{373}$ CORDEIRO, António Manuel da Rocha e Menezes. Da boa fé no direito civil. Almedina, 2011, p. 69.

374 Alípio Silveira destaca que "entre os romanos existia a Fides, com um amplíssimo significado, abrangendo os conceitos de honra, virtude, lealdade, honestidade, probidade e boa-fé". In: ALÍPIO SILVEIRA. A Bôa Fé no Direito Civil. Typ. Paulista, 1941, p. 25.

${ }^{375}$ CORDEIRO, op. cit., p. 59.

${ }^{376}$ CORDEIRO, op. cit, p. 71.

377 Destaca Cordeiro que "o esquema processual romano mais antigo era dado pelo sistema das legis actiones. tratava-se de um processo rígido, altamente formalizado, consubstanciado, essencialmente, em cinco acções: sacramentum, com aplicação mais geral, per iudicis arbitrive postulationem, para a divisão de herança e obrigações ex stipulatione, per condictionem, para condenação em débitos certos e na restituição de coisa certa, per manus iniectionem, para a execução de obrigações dentro do esquema da responsabilidade pessoal, e per pignoris capionem, em certos casos restritos de responsabilidade patrinomial, já admitida. Estas ações apenas viabilizavam a composição de um margem estreita de litígios". In: CORDEIRO, loc. cit.

378 MARTINS, FLAVIO ALVEZ. A boa-fé objetiva e sua formalização no direito das obrigações brasileiro. 2 e.d. Lumen Juris, p . 34. 
exigia a confiança. É justamente do conceito que exprimia confiança (fides) que nasce o conceito objetivo de fides bona, de correção e lealdade que deveria imperar no mundo das relações comerciais ${ }^{379}$. Com isso, a penetração da fides bona no campo dos contratos acaba dando lugar à bona fidei iudicia, ações que diziam respeito à pessoa (actiones civiles in personam - não in rem) e que atribuíam ao juiz uma grande apreciação discricionária, ou seja, o poder de estabelecer, a seu critério, o que o demandado deveria dar ou fazer com amparo no princípio da boa-fé, superando, assim, as dificuldades decorrentes da transição entre as fases leges actiones e formulae, que devido às suas limitações eram insuficientes para atender às necessidades do tráfego jurídico ${ }^{380} 381$.

É interessante notar que o Direito Canônico, muito ligado ao Direito Romano em razão da assimilação da estrutura e da cultura romanas pelos cristãos, dá a uma série de conceitos, por exemplo, a propriedade e o contrato, uma visão própria, pois, para além das sanções profanas, representam a concretização das Leis de Deus, de modo que se afirma na boa-fé um elemento ético, na medida em que atuava na ausência de prescrições $\operatorname{expressas}^{382}$.

Nessa linha de proteção da palavra dada ou da confiança estabelecida, pode-se afirmar que o conteúdo atual da boa-fé objetiva, composto, em parte, pelo dever de lealdade e pelo dever de cooperação entre os contratantes, possui identificação com a fides $^{383}$. Com isso, o dever de lealdade corresponde à fides romana, que representa também a abstenção de qualquer conduta que possa tornar mais onerosa a execução do contrato. Não é outra a conclusão de Flávio Alves Martins, para quem a base da boa-fé contemporânea encontra-se na chamada fides, que significa ser de palavra ou ter palavra (na expressão de Cícero, fid quod dicitur), de modo que a fides pressupõe saber o que

\footnotetext{
379 MARTINS, FLAVIO ALVEZ. A boa-fé objetiva e sua formalização no direito das obrigações brasileiro. 2 e.d. Lumen Juris, p. 35.

380 AMARAL, Francisco. A boa-fé no processo romano. Revista de Direito Civil, Imobiliário, Agrário e Empresarial. Ano 20, outubro-dezembro, 1996, pp. 200-201 e 203.

381 Esclarecemos, em breves palavras, que o processo romano atravessou, basicamente, três períodos distintos, o das legis actiones - extremamente oral e solene, com recitação de formulas verbais perante os magistrados, o formulae - para cada tipo de ação correspondia uma fórmula específica, de modo que a tipicidade processual determinava a tipicidade do próprio direito - e o da cognitio extra ordinem - fase em que o Estado apoderou-se da direção do processo, outrora dominado ou dirigido por particulares. Ibidem, p. 201.

382 CORDEIRO, António Manuel da Rocha e Menezes. Da boa fé no direito civil. Almedina, 2011, pp. 156 e 159.

383 MARTINS, Flávio Alvez. A boa-fé objetiva e sua formalização no direito das obrigações brasileiro. 2 e.d. Lumen Juris, p. 31.
} 
disse, cumprir o que se diz ou o que se promete, refletindo, em síntese, uma exigência de respeito $^{384}$.

Por derradeiro, cumpre observar que outros institutos ligados à boa-fé tiveram origem em Roma, como ocorreu com a teoria da aparência, que surge em razão de escravos que, passando-se por homens livres, praticaram atos em nome de Roma e, uma vez reveladas suas verdadeiras condições e para que se evitassem a anulação de todos os atos, foi editada a Lex Barbarius, dotando de validade e eficácia todos os atos por ele $\operatorname{praticados}^{385}$.

Logo o Direito Romano é o berço da boa-fé.

\section{Histórico brasileiro.}

O Direito vigente no Império e no primeiro centenário da República foi marcado pela ausência de normatização explícita a respeito de uma cláusula geral da boa-fé ${ }^{386}$. Flávio Rubinstein ${ }^{387}$ indica que, ao longo desse período histórico, é digna de relevo a singela menção existente na Lei $\mathrm{n}^{\circ}$ 556, de 25 de junho de 1850, Código Comercial, que, em seu art. 131, consagrava disposição sobre a utilização da boa-fé na interpretação dos contratos comerciais, eis sua redação:

\footnotetext{
"Art. 131 - Sendo necessário interpretar as cláusulas do contrato, a interpretação, além das regras sobreditas, será regulada sobre as seguintes bases:

1 - a inteligência simples e adequada, que for mais conforme à boa fé, e ao verdadeiro espírito e natureza do contrato, deverá sempre prevalecer à rigorosa e restrita significação das palavras".
}

Em idêntica direção, José Fernando Simão, Gustavo Tepedino e Anderson Schreiber registram que a boa-fé, como cláusula geral que impõe o comportamento ético, foi introduzida no ordenamento pátrio apenas com o Código de Defesa do Consumidor -

\footnotetext{
384 MARTINS, Flávio Alvez. A boa-fé objetiva e sua formalização no direito das obrigações brasileiro. 2 e.d. Lumen Juris, p. 32.

385 MOTA, Maurício Jorge. A Teoria da Aparência. Disponível em: <http://www.estig.ipbeja.pt/ ac_direito/teoria_aparencia.pdf>. Acesso em 30.07.2012.

${ }^{386}$ RUBINSTEIN, Flávio. A bona fides como origem da boa-fé objetivo do Direito brasileiro. Revista da Faculdade de Direito USP. São Paulo. V. 99. 2004, p. 582.

${ }^{387}$ RUBINSTEIN, loc. cit.
} 
CDC, não havendo nenhuma menção à figura no Código Civil de $1916^{388}$, em que pese Diógenes Faria de Carvalho e Paulo Guimarães Pereira afiançarem que o pretérito Código Civil fez menção à boa-fé objetiva em seu art. $1.443^{389} 390$. Nota-se que a iniciativa legislativa principiada com a defesa das relações de consumo foi complementada pelo Código Civil de 2002, diploma normativo repleto de proposições prescritivas próprias da boa-fé, seja como ignorância, seja como comportamento ético ${ }^{391}$.

Cabe esclarecer, por outro lado, que o Código Civil de 1916 não silenciou sobre a concepção da boa-fé como desconhecimento ou ignorância, ao contrário do que ocorre com a sua compreensão como adoção da conduta esperada por outrem. O art. $221^{392}$ do mencionado diploma deu especial realce à ignorância ao tratar do casamento putativo, de maneira que considerou de boa-fé aquele que desconhecesse o vício que impedisse a regularidade do ato. Assim, é incorreto afirmar que, sob a vigência do Código Civil de 1916, a boa-fé não possuía previsão, pois o que inexistia era menção à sua concepção ética.

Com efeito, ao longo dos séculos XIX e XX, o acelerado desenvolvimento da economia e o advento de uma sociedade de massas evidenciaram abusos praticados pelos agentes econômicos em prejuízo de contratantes mais vulneráveis. A necessidade de coibir esses abusos e proteger as partes mais frágeis das relações deu margem ao surgimento de diversas medidas, notadamente o Código de Defesa do Consumidor no Brasil ${ }^{393}$.

O CDC faz expressas menções à boa-fé em sua concepção ética, em especial em seu art. $4^{\circ}$, III, e no art. 51, IV:

\footnotetext{
388 Gustavo Tepedino e Anderson Schreiber destacam que "até o advento do Código de Defesa do Consumidor, em 1990, o termo boa-fé era utilizado pelos tribunais brasileiros exclusivamente em sua acepção subjetiva, isto é, como sinônimo de um estado psicológico do sujeito caracterizado pela ausência de malícia, pela sua crença ou suposição pessoal de estar agindo em conformidade com o direito. Era também neste sentido que o Código Civil de 1916 empregava o termo, referindo-se, por exemplo, ao possuidor de boa-fé como aquele que tem a posse de um bem sem consciência de que há um vício ou obstáculo que lhe impede a aquisição do domínio sobre a coisa. Tomada nesse sentido, a existência ou não de boa-fé é questão inteiramente subjetiva, vinculada ao estado anímico do agente". In: TEPEDINO, Gustavo; SCHREIBER, Anderson. Os efeitos da Constituição em Relação à Cláusula da Boa-fé no Código de Defesa do Consumidor e no Código Civil. Revista da EMERJ. Vol. 6. n. ${ }^{\circ} 23.2003$, p. 139.

389 "O segurado e o segurador são obrigados a guardar no contrato a mais estrita boa-fé e veracidade assim a respeito do objeto, como das circunstâncias e declarações a ele concernentes".

390 CARVALHO, Diógenes Faria de; PEREIRA, Paulo Guimarães. A Boa-fé Objetiva como Parâmetro da Análise dos Contratos Administrativos. Fórum de Contratação e Gestão Pública. Ano 2. n. 23 - Novembro de 2003. Editora Fórum, p. 2890.

${ }^{391}$ SIMÃO, José Fernando. Direito Civil: contratos. 2 e.d. 2. reimp. São Paulo: Atlas, 2007, p. 18.

392 "Art. 221. Embora nulo ou anulável, quando contraído de boa fé por ambos os cônjuges, o casamento, em relação a estes como aos filhos, produz todos os efeitos civis desde a data de sua celebração".

${ }^{393}$ TEPEDINO, op. cit., p. 140.
} 
“art. $4^{\circ}$. A Política Nacional de Relações de Consumo tem por objetivo o atendimento das necessidades dos consumidores, o respeito a sua dignidade, saúde e segurança, a proteção de seus interesses econômicos, a melhoria de sua qualidade de vida, bem como a transparência e harmonia das relações de consumo, atendidos os seguintes princípios:

(...)

III - harmonização dos interesses dos participantes das relações de consumo e compatibilização da proteção do consumidor com a necessidade de desenvolvimento econômico e tecnológico, de modo a viabilizar os princípios nos quais se funda a ordem econômica (art. 170, da Constituição Federal), sempre com base na boa-fé e equilíbrio nas relações entre consumidores e fornecedores".

“art. 51. São nulas de pleno direito, entre outras, as cláusulas contratuais relativas ao fornecimento de produtos e serviços:

(...)

IV - estabeleçam obrigações consideradas iníquas, abusivas, que coloquem o consumidor em desvantagem exagerada, ou sejam incompatíveis com a boa-fé ou a equidade".

A letargia do Direito brasileiro é verificada com maior facilidade quando comparado com o Direito estrangeiro. Já no século passado, Códigos como o alemão, o italiano, o espanhol e o português já consagravam uma cláusula geral de boa-fé e por meio dela permitiam a flexibilização do sistema ou, com outros dizeres, a atenuação dos rigores das normas jurídicas, o que possibilitava ao Judiciário buscar no seio do sistema as alternativas mais acordes com a solução dos conflitos ${ }^{394}$, o que a jurisprudência brasileira inclusive já vinha admitindo mesmo antes do vigente Código Civil ${ }^{395}$.

394 Judith H. Martins Costa ensina que "à evidência, a introdução dessa idéias nos sistemas de direito codificado, e em especial naqueles assentados no dogma da autonomia da vontade, não se fez sem dificuldades. Os códigos que consignam, como o alemão, o italiano, o espanhol e o português, entre outros, cláusula geral de boa-fé, permitiram, entretanto, por essa importantíssima técnica legislativa, a flexibilização do sistema, de modo que foi possível à jurisprudência buscar, no interior do próprio corpus codificado, as soluções mais acordes ao direito justo em matéria de contratos. À evidência, as dificuldades foram muito maiores nos sistemas carentes de cláusula geral de boa-fé, como o brasileiro, porque, à falta de uma via que expressamente permitisse a inserção dos valores vigentes, no Direito codificado, não parecia ser possível a sistematização, por via da criação jurisprudencial, das soluções social e historicamente recomendadas à boa (isto é, à justa) solução dos casos levados à apreciação judicial. Neste ponto, precisamente, reside o inestimável valor das decisões ora comentadas que, superando tal obstáculo, ditaram o Direito adequado à solução dos conflitos”. In: COSTA, Judith H. Martins. Princípio da boa-fé. in Revista da Associação dos Juízes do Rio Grande do Sul, n. ${ }^{\circ}$ 50, p. 224.

${ }^{395}$ Nesse sentido, afirmam Gustavo Tepedino e Anderson Schreiber que "até janeiro de 2003, o ordenamento positivo brasileiro mantinha a boa-fé objetiva no âmbito das relações de consumo. A jurisprudência, contudo, já estendia a sua aplicação a relações contratuais em que se verificasse a presença de uma parte vulnerável a ser protegida. Continuavam raros os casos de aplicação do instituto a relações contratuais paritárias. De fato, os tribunais brasileiros haviam se acostumado a compreender e a aplicar a boa-fé objetiva objetiva como um princípio reequilibrador e de forte caráter protetivo, e, por esta razão, relutavam em estender sua incidência às relações contratuais em que não se vislumbrasse a vulnerabilidade de uma das partes. O novo Código Civil brasileiro veio corrigir essa tendência, prevendo expressamente a aplicação do princípio da boa-fé 


\section{O que é a boa-fé?}

A indicação da natureza jurídica da boa-fé está atrelada à positivação que o conjunto de normas a confere ${ }^{396}$. Depreende-se do art. 422 do Código Civil a compreensão da boa-fé como dever de conduta, que orienta o aplicador do Direito na solução do conflito, de modo que ele estabeleça o comportamento a ser observado na hipótese submetida a sua apreciação. Esses contornos indicam que a boa-fé, que estabelece deveres de conduta, pode ser entendida como cláusula geral ${ }^{397}$. Segundo Judith Martins H. Costa e Gerson Luiz Carlos Branco, as cláusulas gerais podem ser compreendidas como normas jurídicas legisladas, incorporadas de um princípio ético orientador do juiz na solução do caso concreto, autorizando-o a estabelecer, de acordo com aquele princípio, a conduta que deveria ter sido adotada no caso $^{398}$.

Por outro lado, há quem identifique a boa-fé como um standard. Nesse sentido, encontramos Maria Clara Osuna Diaz Falavina, para quem standard jurídico pode ser considerado o conteúdo básico e essencial de uma norma jurídica, que exige uma interpretação para sua completude, uma vez que não consiste em um conceito estático, pois não está presente em todas as normas, mas somente naquelas que apresentam um contexto aberto, pelo que costuma ser denominado como um conceito jurídico indeterminado ou cláusula geral, ou, também, cláusula aberta, não se confundindo, contudo, com o sentido dessas expressões, tendo em vista que possuem em comum apenas a necessidade de seu preenchimento como critério de integração ${ }^{399}$. No mesmo sentido, afirmam Diógenes Faria de Carvalho e Paulo Guimarães Pereira que a boa-fé recebe, na atualidade, o tratamento jurídico de standard, ou seja, de técnica que permite adaptar uma regra de direito ao comportamento médio em uso em uma dada sociedade ${ }^{400}$.

objetiva às relações contratuais comuns, independentemente de qualquer vulnerabilidade presumida ou demonstrada...". In: TEPEDINO, Gustavo; SCHREIBER, Anderson. Os efeitos da Constituição em Relação à Cláusula da Boa-fé no Código de Defesa do Consumidor e no Código Civil. Revista da EMERJ. Vol. 6. n. ${ }^{\circ}$ 23. 2003, p. 140.

${ }^{396}$ CORDEIRO, António Manuel da Rocha e Menezes. Da boa fé no direito civil. Almedina. 2011, p. 1195.

${ }^{397}$ ALPA, Guido. La buena fe integrativa. In Tratado de la Buena Fe en el Derecho. Marcos M. Córdoba (Diretor) - 1. ed.v.2. Buenos Aires: La Ley, 2004, p. 177.

${ }^{398}$ COSTA, Judith H. Martins Costa; BRANCO, Gerson Luiz Carlos. Diretrizes teóricas do novo código civil. Saraiva, 2002. p. 5.

${ }^{399}$ FALAVIGNA, Maria Clara Osuna Diaz. Os princípios gerais do direito e os standards jurídicos no código civil. Universidade de São Paulo. 2007. Orientadora: Professora Doutora Daisy Gogliano p. 171.

${ }^{400}$ CARVALHO, Diógenes Faria de; PEREIRA, Paulo Guimarães. A Boa-fé Objetiva como Parâmetro da Análise dos Contratos Administrativos. Fórum de Contratação e Gestão Pública. Ano 2. n. ${ }^{\circ} 23$ - Novembro de 2003. Editora Fórum, p. 2891. 
Na há distinções substanciais entre cláusula geral e standard. Essa afirmação pode ser extraída do exposto nos parágrafos anteriores, que indicam a incidência nas duas figuras de preceitos gerais, que exigem a atuação do aplicador das normas jurídicas para a solução de conflitos, valendo-se de preceitos que ultrapassam as fronteiras do Direito entendido como norma jurídica ${ }^{401}$. Contudo, caso se pretenda a fixação de distinção entre as figuras, coadunando-se com os rigores de um trabalho científico, e que também se apreende dos parágrafos pregressos, pode-se dizer que as cláusulas gerais seriam os continentes nos quais estão contidos os standars, vale dizer, os preceitos atualizáveis segundo as situações que se apresentem.

Com amparo nos ensinamentos de Nelson Rosenvald podemos arrematar dizendo que a boa-fé, como cláusula geral, representa uma regra que impõe ao magistrado o dever de examinar o caso em duas etapas. Primeiro, fixa a norma de dever segundo a realidade do fato e o princípio em destaque. Em seguida, o magistrado confronta a conduta realizada com aquela que as peculiaridades do caso sugeririam ${ }^{402}$. Vê-se, assim, que a compreensão em relevo da boa-fé permite a fixação de soluções acomodáveis às necessidades reveladas pelos fatos que embasam o litígio.

Por outro lado, a boa-fé entendida como ignorância não possui os contornos supra, de maneira que não pode ser considerada cláusula geral que possibilite soluções distintas de acordo com o caso que se apresente. Isso em razão da necessidade de a ignorância ou a crença em não lesar estar contida em normas jurídicas específicas, de modo a indicar a posição de um sujeito em relação a algum fato ou pressuposto de validade.

Na boa-fé enquanto crença tem-se a posição de quem ignora determinados fatos e pensa, assim, que sua conduta é perfeitamente correta e não causa prejuízos a ninguém. É o que se passa, por exemplo, com o possuidor de boa-fé, que ignora o vício ou o obstáculo que impede a aquisição da coisa ou do direito possuído, e com o cônjuge que contrai um matrimônio putativo, uma vez que ignora o impedimento ou o erro essencial. Por outro aspecto, a boa-fé como lealdade compreende a conduta da pessoa que considera cumprir realmente com o seu dever, pressupõe uma posição de honestidade e honradez no tráfego jurídico, tendo em vista que contém implícita a plena consciência de não enganar, não prejudicar, nem causar danos, mas vai além, acarreta a convicção de que as transações são

\footnotetext{
${ }^{401}$ CORDEIRO, António Manuel da Rocha e Menezes. Da boa fé no direito civil. Almedina. 2011, p. 1182. ${ }^{402}$ ROSENVALD, Nelson. Dignidade humana e boa-fé no código civil. São Paulo: Saraiva, 2005, p. 167.
} 
cumpridas normalmente, sem trapaças, sem abusos, nem desvirtuamentos.

Em suma, existem duas concepções, uma na qual o sujeito ignora o caráter ilícito de seu ato, isto é, um estado de ignorância que recebe o nome de boa-fé subjetiva, e outra que significa a exigência de comportamento adequado com a diligência socialmente exigida, vale dizer, representa elementos externos que determinam como o sujeito deve agir, o que lhe rende a alcunha de boa-fé objetiva ${ }^{403}$. O desenvolvimento das concepções em apreço ${ }^{404}$ é de grande relevo para o presente trabalho, contudo, antes do necessário aprofundamento, verifiquemos o aspecto fático e o aspecto principiológico da boa-fé.

\section{Boa-fé como fato e como princípio.}

Pode-se compreender a boa-fé como fato e como princípio, compreensões intimamente ligadas. Essa distinção diz respeito, de certo modo, ao suporte fático das normas de boa-fé, isto é, o fato necessário à ocorrência das consequências estabelecidas, e, assim, manifesta-se como crença ou como comportamento leal. Como princípio, representa a própria repercussão jurídica, como a concessão de direitos e a imposição de outras obrigações que ultrapassam as fronteiras das expressamente consagradas em lei. Logo, não seria incorreto afirmar que se cuida de duas manifestações do mesmo fenômeno.

A boa-fé repercute no mundo das relações jurídicas, manifestando-se de dois modos já mencionados, quais sejam, a errônea crença da existência de determinada situação, ou ainda, o desconhecimento de determinada situação (boa-fé crença) e, também, o dever de atuar com lealdade (boa-fé lealdade). Veja-se, desse modo, que a primeira refere-se ao conhecimento humano e a segunda, a ação ${ }^{405}$. Segundo Alípio Silveira, essa última distinção subsidia a classificação feita em boa-fé subjetiva e objetiva, referindo-se essa à lealdade e aquela, ao desconhecimento ${ }^{406}$, o que acaba por indicar as estreitas

\footnotetext{
${ }^{403}$ MELLO, Marcos Bernardes de. Teoria do fato jurídico: plano da validade. 9. e.d. São Paulo: Saraiva, 2009, p. 90.

${ }^{404}$ Para Flávio Alves Martins a boa-fé "em sentido objetivo, um dever das partes de uma relação jurídica em comportar-se, tomando-se por fundamentos a confiança que deve existir, de maneira correta e leal, mais especificamente, caracteriza-se como retidão e honradez dos sujeitos do direito que participam de uma relação jurídica, pressupondo o fiel cumprimento do estabelecido; em sentido subjetivo, é a crença de não estar lesando o direito de outrem, o sujeito age sem conhecimento de que prejudica melhor direito". In: MARTINS, Flávio Alves. A boa-fé objetiva e sua formalização no direito das obrigações brasileiro. 2 e.d. Lumen Juris, p. 9.

${ }^{405}$ SILVEIRA, Alípio. A Bôa Fé no Direito Civil. Typ. Paulista, 1941, pp. 29-31.

${ }^{406}$ Ibidem, p. 30.
} 
ligações entre as manifestações da boa-fé. Todavia, para que se evitem equívocos, cumpre afirmar que o fato da boa-fé ocorre necessariamente em sua vertente subjetiva e em sua vertente objetiva, não se cuidando de manifestação exclusiva de nenhuma das espécies, porquanto constitui o antecedente necessário à repercussão normativa da boa-fé em suas duas vertentes.

Ao se tratar do erro ou ignorância, é essencial estabelecer a distinção entre o desconhecimento da lei e o desconhecimento da realidade fática. Essa diferenciação não se impõe sem propósito, pois toca à imperatividade do Direito na medida em que está intimamente vinculada à obrigatoriedade das normas jurídicas. Rememoremos que a LINDB - Lei de Introdução às Normas do Direito Brasileiro - impõe uma presunção absoluta de conhecimento das leis ${ }^{407}$, de modo que as imposições legais, como a exigência constitucional de prévia aprovação em certame para acesso aos postos de trabalho públicos, não poder ser tida, nem mesmo alegada, como desconhecida pelos cidadãos. Contudo, pode ocorrer uma percepção incorreta sobre os fatos propriamente ditos, uma vez que, conquanto não possa ignorar a lei, pode o trabalhador desconhecer ou confundir a realidade com a qual se depara.

Passemos à manifestação principiológica.

Américo Plá Rodriguez define princípios como linhas diretrizes que informam algumas normas e inspiram direta ou indiretamente uma série de soluções, pelo que podem servir para promover e embasar a aprovação de novas normas, orientar a interpretação das existentes e resolver os casos não previstos ${ }^{408}$. O autor uruguaio descreve os princípios como enunciados básicos que contemplam, abrangem e compreendem uma série indefinida de situações; acrescenta que existem princípios gerais e princípios próprios, destacando, ainda, a peculiaridade de existirem princípios comuns a mais de uma seara do Direito. Como terceiro ponto de descrição, ainda na esteira dos ensinamentos do doutrinador em evidencia, os princípios devem possuir ligação entre si, pois constituem ou perfilham a fisionomia característica de determinado ramo autônomo do Direito ${ }^{409}$.

\footnotetext{
407 "Art. $3^{\text {o }}$ Ninguém se escusa de cumprir a lei, alegando que não a conhece".

408 RODRIGUEZ, Américo Plá. Princípios de direito do trabalho: tradução de Wagner D. Giglio. São Paulo: LTr, Ed. Da Universidade de São Paulo, 1978, p. 16.

${ }^{409}$ Ibidem, p. 17.
} 
Depreende-se do exposto acima, sem prejuízo de outras conclusões retiráveis, a função normativa subsidiária ou supletiva dos princípios, que autoriza sua utilização exclusivamente nas hipóteses em que as regras jurídicas são omissas ou insuficientes à solução dos litígios apresentados ao aplicado do Direito. Porém, o enclausuramento da função normativa dos princípios a uma incidência subsidiária empobreceria o sistema jurídico, porquanto tornaria demasiadamente fechado o ordenamento jurídico, o que também acabaria desatualizando-o com demasiada velocidade, considerando a constante corrida dos criadores do direito, os legisladores nomeadamente, atrás da realidade.

Todavia, o desenvolvimento da função normativa não findou no estágio subsidiário. Em verdade, a eficácia normativa dos princípios passou por três etapas distintas. Na primeira, eles eram vistos como axiomas, isto é, como verdades de origem humana ou divina. Nessa concepção, os princípios não são normas jurídicas, pois esse conceito é próprio do positivismo, ao passo que os princípios, a essa época, eram figuras metajurídicas $^{410}$.

A segunda fase, de traços positivistas, explica os princípios por meio de um raciocínio lógico dedutivo ou indutivo. Seu enfoque, em postura diversa da concepção anterior, está no próprio ordenamento jurídico, deixando, assim, de ser uma figura metajurídica. Nesta concepção, o sistema jurídico diz-se fechado, pois é uma unidade completa e dessas peculiaridades derivam duas conclusões: o juiz não pode criar direito e o juiz não pode se recusar a decidir ${ }^{411}$.

Por sua vez, na terceira fase, dita pós-positivista, desloca-se o eixo do Direito Civil para o Direito Constitucional. Nesse ponto, diz-se que o sistema jurídico é aberto, pois os princípios passam a ser aplicados com prioridade sobre as normas (regras), uma vez que representam a ligação do mundo social e do sistema jurídico. Ainda, é nessa fase que os princípios ganham a força normativa primária ou imediata, de modo que são utilizados como elemento de integração direcionado a garantir, apenas, a integridade do sistema, como ocorria na fase positivista ${ }^{412}$.

Desde a fase positivista, já era possível identificar o caráter normativo do princípio, uma vez que ele era utilizado como elemento de integração do sistema. Nota-se

${ }^{410}$ NEGREIROS, Teresa Paiva de Abreu Trigo de. Fundamentos para uma interpretação constitucional do princípio da boa-fé. Rio de Janeiro: Renovar, 1998, pp. 139-140.

${ }^{411}$ Ibidem, pp. 141-143.

412 Ibidem, p. 146. 
em referida fase que os princípios se destinavam a garantir a unidade ou a inteireza do sistema, de maneira que apenas encontravam incidência nos casos de lacuna do Direito. Já na fase pós-positivista, o caráter normativo permite que os princípios incidam, imediatamente, sobre as relações jurídicas ${ }^{413}$.

No pós-positivismo, os princípios são compreendidos como valores fundamentais da ordem jurídica, de modo que os princípios constitucionais condicionam a aplicação das regras infraconstitucionais ${ }^{414}$, o que não elide a existência de conflitos entre princípios ou entre princípios e regras de idêntica hierarquia.

Veja-se que a concepção positivista, surgida com as codificações, pautava-se em dogmas como o caráter sagrado da propriedade privada e o poder da vontade do sujeito. $\mathrm{O}$ Direito, nesta concepção, é puramente lógico e tendencialmente imutável e a-histórico, pois pretende a manutenção das coisas. A nova técnica, pós-positivista, pretende a atualização do sistema de acordo com os valores presentes no ordenamento jurídico vigente $^{415}$. Não é outro o entendimento de Judith H. Martins Costa ao afirmar que a doutrina, em especial a europeia, vem chamando a atenção para o fato de o Direito Moderno dos contratos não nascer somente dos princípios da autodeterminação e da autovinculação, mas, também, do comportamento leal que deve ser observado em todos os momentos do contrato ${ }^{416}$.

Outra característica merece realce, no sistema aberto pós-positivista, a Constituição ocupa o ponto mais alto do ordenamento jurídico. Nele, os princípios servem como elementos capazes de conectá-lo a outros sistemas, como o social, o cultural, o ético, $\operatorname{etc}^{417}$.

Segundo Teresa Paiva de Abreu Trigo de Negreiros, foi somente a partir do momento em que se reconheceu a abertura do sistema jurídico é que os princípios puderam ser reconhecidos como chave para a aplicação-realização do Direito, e não mais como

\footnotetext{
${ }^{413}$ NEGREIROS, Teresa Paiva de Abreu Trigo de. Fundamentos para uma interpretação constitucional do princípio da boa-fé. Rio de Janeiro: Renovar, 1998, p. 146.

${ }^{414}$ NEGREIROS, loc. cit.

415 Ibidem, p. 161.

${ }^{416}$ COSTA, Judith H. Martins Costa. Princípio da boa-fé. in Revista da Associação dos Juízes do Rio Grande do Sul, n. ${ }^{\circ}$ 50, p. 222.

${ }^{417}$ NEGREIROS, op. cit., p. 166.
} 
mecanismos de integração supletiva do que então se reputava como um sistema autônomo, neutro e autorreferente ${ }^{418}$.

Dentro do entendimento da boa-fé como princípio, com as proporções que o póspositivismo o proporciona, encontramos diversas características que auxiliam na compreensão de suas possibilidades e limitações, a saber: universalidade - indica a ausência de exclusividade dos princípios, o que possibilita a aplicação de mais de um princípio em uma relação jurídica ${ }^{419}$, ou ainda, diante de um conflito diversos princípios podem ser utilizados; historicidade - partindo-se da ideia de que o Direito é um produto cultural, diz-se que os princípios variam de acordo com a época, o lugar e a sociedade; potencialidade jurígena - precedem e embasam a ordem jurídica ${ }^{420}$.

Consoante Alípio Silveira, a boa-fé, em sua faceta principiológica, possui as seguintes funções: supridora de nulidades, integradora da capacidade e sanadora de vícios, interpretativa da lei e da vontade das partes, moralizadora do Direito e das condutas humanas em geral ${ }^{421}$.

Mas não se esgotam aí suas funções. São dignas de nota, também, a função geradora de efeitos e a função de imposição de obrigações. A primeira, diante da ignorância do sujeito, que será tido como de boa-fé, proporcionará, por exemplo, a produção de efeitos em negócios jurídicos nulos. Pela segunda, são impostas diversas obrigações aos contratantes, além das expressamente consagradas em lei. Assim, a abrangência da boa-fé é ampla, passando pela imposição de deveres e atingindo, até mesmo, a produção de efeitos diante de nulidades ${ }^{422}$.

Vejamos um pouco mais acerca das funções da boa-fé como princípio.

\footnotetext{
${ }^{418}$ NEGREIROS, Teresa Paiva de Abreu Trigo de. Fundamentos para uma interpretação constitucional do princípio da boa-fé. Rio de Janeiro: Renovar, 1998, p. 167.

419 MARTINS, FLAVIO ALVEZ. A boa-fé objetiva e sua formalização no direito das obrigações brasileiro.

2 e.d. Lumen Juris, p. 11.

${ }^{420}$ Ibidem, p. 121.

${ }^{421}$ SILVEIRA, Alípio. A Bôa Fé no Direito Civil. Typ. Paulista, 1941, p. 7.

${ }^{422}$ De acordo com Alexandre Agra Belmonte o princípio da boa-fé implica nos deveres de lealdade e colaboração no desempenho das cláusulas do contrato e no relacionamento entre as partes, uma vez que decorre do princípio geral da eticidade e, para o cumprimento do princípio geral da socialidade, deve ser subjetiva (boa-fé persuasão) e objetivamente (boa-fé lealdade). In: BELMONTE, Alexandre Agra. Instituições civis no direito do trabalho - curso de direito civil aplicado ao direito do trabalho. 4. ed. atualizada de acordo com o novo Código Civil de 2002 e a Emenda Constitucional no 45/2004. Rio de Janeiro: Renovar, 2009, p. 54.
} 


\section{As funções do princípio da boa-fé.}

Muito embora tenha se desenvolvido nos campos do Direito Civil, ou na sua origem remota, o Direito Romano, a boa-fé não se esvai nessa seara do Direito, espraiando-se por toda a ordem jurídica e por toda a sociedade. Ao lado dessa presença generalizada, é própria da boa-fé sua atuação específica nos conflitos, de modo a adaptarse às necessidades que deve satisfazer ${ }^{423}$. Não poderia ocorrer de modo distinto em razão da ductilidade da boa-fé e, igualmente, em razão de o legislador brasileiro não ter estabelecido parâmetros de conduta que servissem de auxílio na determinação de uma cláusula geral de boa-fé.

Mencionada moldura normativa fortalece, sobremaneira, o papel do aplicador do Direito que, ao analisar a situação concreta, o comportamento usual no campo específico em que se enquadra, a honestidade, a lealdade, verificará qual a melhor solução. A atuação do aplicador do Direito, nesse sentido, isto é, valendo-se de preceito amplo, não se cuida de novidade, uma vez que há previsões no ordenamento jurídico que autorizam, se não impõem, a solução de conflitos com o emprego da igualdade ${ }^{424}$ e dos princípios gerais do Direito $^{425}$.

Perceba-se, nesse contexto, que a boa-fé destina-se a estabelecer os limites do pactuado, o que permite ao julgador, inclusive, intervir nos deveres e obrigações estabelecidos pelas partes ${ }^{426427}$ e, ainda, exige-se que a interpretação dos negócios ocorra de modo a privilegiar a lealdade e a honestidade entre seus celebrantes ${ }^{428}$.

\footnotetext{
${ }^{423}$ Segundo Loussouarn "sin duda, la verdad se situa a mitad de camino entre estas dos posiciones extremas, y el conjunto de informes y discusiones revelo que la buena fe - ya sea considerada como un concepto multiforme o como un concepto uniforme de multiples facetas - debía ser abordada desde una perspectiva doble. Presenta un doble aspecto que por outra parte rimete al origen de su auge y explica la suerte que corre em la actualidad. Por un lado, como el caimán que vive indiferentemente en la tierra o em el água, la buena fé puede manifestarse em todos los ámbitos (de allí su generalidad) y prosperar devorándose las técnicas competidoras. Se trata de la buena fe-caimán (Primeira parte). Por outro lado, tiene además la capacidad de adaptarse a las necessidades que debe satisfacer y que pueden variar de una disciplina a outra. El poder de mimetismo del que está dotada hace de ella um concepto proteiforme. Es la buena fe-camaleon (segunda parte). In: LOUSSOUARN. M. Ivon. Tratado de la Buena Fe en el Derecho. Marcos M. Córdoba (Diretor) - 1.ed. v.2. Buenos Aires: La Ley, 2004, p. 7.

424 "CPC. Art. 127. O juiz só decidirá por equidade nos casos previstos em lei".

425 “CPC. Art. 126. O juiz não se exime de sentenciar ou despachar alegando lacuna ou obscuridade da lei. No julgamento da lide caber-lhe-á aplicar as normas legais; não as havendo, recorrecorá à analogia, aos costmes e aos princípios gerais do direito".

${ }^{426}$ MARTINS, FLAVIO ALVEZ. A boa-fé objetiva e sua formalização no direito das obrigações brasileiro. 2 e.d. Lumen Juris, p. 20.

${ }^{427}$ Flávio Alvez Martins obtempera que "entendendo-se como um dos objetivos básicos do grupo social que é a finalidade do direito, interpretar de acordo com a boa-fé é uma forma de manter a paz e a harmonia, realçando um dos valores fundamentais da sociedade (a segurança), provocando o respeito às normas
} 
Ainda, a boa-fé representa limitação às condutas humanas. Outrora, a atuação em sociedade era pautada no entendimento de serem permitidas todas as condutas não proibidas. Contemporaneamente, a vedação de condutas também decorre de princípios, em especial da boa-fé, que exige o comportamento leal dos contratantes. Afigura-se, desse modo, como critério para distinção entre o exercício regular e irregular ou abusivo de um direito, figura introduzida no ordenamento jurídico brasileiro por meio do art. 187 do Código Civil ${ }^{429}$. Em consequência, a atuação em descumprimento do dever de lealdade acarreta sanção jurídica, seja a invalidade da convenção, seja a imposição de reparar perdas e danos ${ }^{430}$.

Igualmente, a boa-fé possibilita a oferta de soluções peculiares aos casos que se apresentem, isto é, permite a adequação da lei à situação particular, bem como supri as lacunas do Direito ${ }^{431}$. Com efeito, a boa-fé é utilizada como fonte secundária do Direito ou como elemento de sua integração, o que também a alinha como princípio geral de Direito. Por conseguinte, a boa-fé, compreendida como princípio geral, exerce a relevante função de proporcionar a solução de conflitos nos casos em que as normas se revelarem insuficientes.

A boa-fé, também, é empregada na criação de deveres anexos, além de poder ser utilizada na concessão de direitos, função última de extremo relevo para o presente trabalho.

Observam Gustavo Tepedino e Anderson Schreiber que a boa-fé exerce a função de fonte criadora de deveres anexos à prestação principal, impondo, pois, às partes outros deveres que não aqueles previstos no negócio jurídico. Mencionada função possui previsão no art. 422 do Código Civil ${ }^{432}$.

Por fim, a boa-fé pode ser utilizada na concessão de direitos, vale dizer, como função que proporciona a produção de efeitos a atos ou negócios jurídicos nulos, no que

elementares de convivência: todos tem, juridicamente, o dever de assim agir". In: MARTINS, FLAVIO ALVEZ. A boa-fé objetiva e sua formalização no direito das obrigações brasileiro. 2 e.d. Lumen Juris, p. 21. ${ }^{428}$ A função interpretativa da boa-fé está prevista no art. 113 do Código Civil, de seguinte redação "os negócios jurídicos devem ser interpretados conforme a boa-fé e os usos do lugar de sua celebração”.

${ }^{429}$ TEPEDINO, Gustavo; SCHREIBER, Anderson. Os efeitos da Constituição em Relação à Cláusula da Boa-fé no Código de Defesa do Consumidor e no Código Civil. Revista da EMERJ. Vol. 6. n. o 23. 2003, p. 145.

${ }^{430}$ MARTINS, op. cit, p. 23.

${ }^{431}$ Ibidem, p. 24.

432 TEPEDINO, loc. cit. 
poderia ser chamada de função excludente de ineficácia ou ampliativa de eficácia, pois, não olvidemos, a pena ou consequência jurídica da nulidade é a ausência ou a drástica redução de efeitos próprios do ato ou negócio jurídico. É exemplo dessa função a concessão de direitos nos casos de casamento putativo, de posse de boa-fé e, a nosso ver, nas hipóteses de prestação de serviços subordinados à Administração Pública sem observância da regra do concurso público. Ressalte-se, porém, que não estamos defendendo a convalidação da nulidade resultante desse último caso, mas apenas a concessão de direitos trabalhistas até o momento do reconhecimento e da cessação da nulidade.

\section{Boa-fé subjetiva e boa-fé objetiva.}

A boa-fé subjetiva é considerada como o estado de consciência, ou o convencimento individual de estar em conformidade com a lei ${ }^{433}$. É nesse sentido que a boa-fé também é chamada de boa-fé crença ou boa-fé em sentido psicológico ${ }^{434}$. Decorre justamente da presença ou da ausência da consciência a distinção entre boa e má-fé. Não é demasiado observar, muito embora sua denominação assim já o sugira, que a concepção subjetiva da boa-fé diz respeito a uma qualidade própria do sujeito.

Celeuma de relevo repousa em saber se a boa-fé subjetiva representa apenas um estado de ignorância pura e simples de certos vícios, concepção psicológica, ou se também é necessário aferir a adoção dos deveres de cautela, concepção ética. Em razão da imposição de condutas para a verificação da boa-fé do sujeito, verifica-se, sem grande dificuldade, que a eticidade inerente à boa-fé impõe situação mais gravosa quando comparada com a singela alegação de ignorância. Todavia, como afirma Menezes Cordeiro, a concepção ética foi defendida com amparo na necessidade de não se premiar o negligente e, ainda, nos requisitos do erro relevante na formação dos negócios jurídicos ${ }^{435}$.

Essa distinção ou identificação da escolha feita pelo legislador, para além das repercussões no campo doutrinário, traz consequências no campo da prova da boa-fé. Isso porque, partindo-se de uma concepção psicológica da boa-fé, caberia ao aplicador do

\footnotetext{
${ }^{433}$ COSTA, Judith Martins. A boa-fé no Direito Privado. São Paulo: Revista dos Tribunais, 1999, p. 411.

${ }^{434}$ PASQUALOTTO, Adalberto. A boa-fé nas obrigações civis. In: MEDEIROS, Antonio Paulo Cachapuz (org.). O ensino jurídico no limiar do século. Porto Alegre: EDIPUCRS, 1997, p. 111.

${ }^{435}$ CORDEIRO, António Manuel da Rocha e Menezes. Da boa fé no direito civil. Almedina, 2011, p. 421.
} 
direito decidir se o sujeito possui o conhecimento dos fatos, a partir de indícios ${ }^{436}$, o que, segundo Menezes Cordeiro, é temerário diante da possibilidade de, mesmo diante de sinais contrários aos interesses do sujeito, ele ignorar ou desconhecer os fatores decisivos da boafé. Vingando a concepção ética, que representa um estado de ignorância desculpável, seria imperioso verificar se o sujeito cumpriu todos os cuidados impostos pela situação, algo que não é aferível em abstrato, mas apenas diante de circunstâncias concretas, o que impossibilita e afasta a comodidade de refugiar a questão em um dever geral de honestidade ${ }^{437}$.

Os contornos normativos da boa-fé subjetiva, dados pelo Código Civil, em seus arts. $167, \S 2^{\text {o }}{ }^{438}, 307$, parágrafo único ${ }^{439}, 309^{440}, 523^{441}, 606^{442}, 686^{443}, 689^{444}, 814, \S 1^{\text {o }}$ ${ }^{445}, 856$, parágrafo único ${ }^{446}, 1.149^{447}, 1.201$, parágrafo único ${ }^{448}, 1.214^{449}, 1.219^{450}, 1.255^{451}$,

${ }^{436}$ Em tópico próprio será abordada a prova da boa-fé, o que incluirá a análise dos indícios.
${ }^{437}$ CORDEIRO, António Manuel da Rocha e Menezes. Da boa fé no direito civil. Almedina, 2011, pp. 515518.

438 “Art. 167. É nulo o negócio jurídico simulado, mas subsistirá o que se dissimulou, se válido for na substância e na forma.

(...)

§ 20 Ressalvam-se os direitos de terceiros de boa-fé em face dos contraentes do negócio jurídico simulado".

439 “Art. 307. Só terá eficácia o pagamento que importar transmissão da propriedade, quando feito por quem possa alienar o objeto em que ele consistiu.

Parágrafo único. Se se der em pagamento coisa fungível, não se poderá mais reclamar do credor que, de boafé, a recebeu e consumiu, ainda que o solvente não tivesse o direito de aliená-la".

440 "Art. 309. O pagamento feito de boa-fé ao credor putativo é válido, ainda provado depois que não era credor".

441 "Art. 523. Não pode ser objeto de venda com reserva de domínio a coisa insuscetível de caracterização perfeita, para estremá-la de outras congêneres. Na dúvida, decide-se a favor do terceiro adquirente de boafé".

442 “Art. 606. Se o serviço for prestado por quem não possua título de habilitação, ou não satisfaça requisitos outros estabelecidos em lei, não poderá quem os prestou cobrar a retribuição normalmente correspondente ao trabalho executado. Mas se deste resultar benefício para a outra parte, o juiz atribuirá a quem o prestou uma compensação razoável, desde que tenha agido com boa-fé".

443 "Art. 686. A revogação do mandato, notificada somente ao mandatário, não se pode opor aos terceiros que, ignorando-a, de boa-fé com ele trataram; mas ficam salvas ao constituinte as ações que no caso lhe possam caber contra o procurador".

444 "Art. 689. São válidos, a respeito dos contratantes de boa-fé, os atos com estes ajustados em nome do mandante pelo mandatário, enquanto este ignorar a morte daquele ou a extinção do mandato, por qualquer outra causa".

445 “Art. 814. As dívidas de jogo ou de aposta não obrigam a pagamento; mas não se pode recobrar a quantia, que voluntariamente se pagou, salvo se foi ganha por dolo, ou se o perdente é menor ou interdito.

$\S 10$ Estende-se esta disposição a qualquer contrato que encubra ou envolva reconhecimento, novação ou fiança de dívida de jogo; mas a nulidade resultante não pode ser oposta ao terceiro de boa-fé".

446 "Art. 856. Antes de prestado o serviço ou preenchida a condição, pode o promitente revogar a promessa, contanto que o faça com a mesma publicidade; se houver assinado prazo à execução da tarefa, entender-se-á que renuncia o arbítrio de retirar, durante ele, a oferta.

Parágrafo único. O candidato de boa-fé, que houver feito despesas, terá direito a reembolso".

447 "Art. 1.149. A cessão dos créditos referentes ao estabelecimento transferido produzirá efeito em relação aos respectivos devedores, desde o momento da publicação da transferência, mas o devedor ficará exonerado se de boa-fé pagar ao cedente". 
$1.561, \S 1^{\mathrm{o}}{ }^{452}, 1.817^{453}, 1.828^{454}$, revelam que a única exigência estabelecida pelo legislador é a ignorância, isto é, refere-se, somente, à concepção psicológica. Por outro lado, extrai-se dos arts. $286^{455}, 879^{456}, 896^{457}, 925^{458}, 1.049^{459}, 1.242^{460}, 1.259^{461}, 1.260^{462}$, algo além da ignorância para o preenchimento de seus pressupostos fáticos, o que não é suficiente à afirmação, sob o enfoque normativo, da existência de uma concepção ética da boa-fé, que acabe por impor a adoção de deveres de cautela pelo interessado.

No que se refere à jurisprudência, a consulta a repertórios e sítios de pesquisa

448 “Art. 1.201. É de boa-fé a posse, se o possuidor ignora o vício, ou o obstáculo que impede a aquisição da coisa.

Parágrafo único. O possuidor com justo título tem por si a presunção de boa-fé, salvo prova em contrário, ou quando a lei expressamente não admite esta presunção".

449 "Art. 1.214. O possuidor de boa-fé tem direito, enquanto ela durar, aos frutos percebidos.

Parágrafo único. Os frutos pendentes ao tempo em que cessar a boa-fé devem ser restituídos, depois de deduzidas as despesas da produção e custeio; devem ser também restituídos os frutos colhidos com antecipação".

450 “Art. 1.219. O possuidor de boa-fé tem direito à indenização das benfeitorias necessárias e úteis, bem como, quanto às voluptuárias, se não lhe forem pagas, a levantá-las, quando o puder sem detrimento da coisa, e poderá exercer o direito de retenção pelo valor das benfeitorias necessárias e úteis".

451 “Art. 1.255. Aquele que semeia, planta ou edifica em terreno alheio perde, em proveito do proprietário, as sementes, plantas e construções; se procedeu de boa-fé, terá direito a indenização”.

452 “Art. 1.561. Embora anulável ou mesmo nulo, se contraído de boa-fé por ambos os cônjuges, o casamento, em relação a estes como aos filhos, produz todos os efeitos até o dia da sentença anulatória.

$\S 1$ o Se um dos cônjuges estava de boa-fé ao celebrar o casamento, os seus efeitos civis só a ele e aos filhos aproveitarão".

453 “Art. 1.817. São válidas as alienações onerosas de bens hereditários a terceiros de boa-fé, e os atos de administração legalmente praticados pelo herdeiro, antes da sentença de exclusão; mas aos herdeiros subsiste, quando prejudicados, o direito de demandar-lhe perdas e danos".

454 “Art. 1.828. O herdeiro aparente, que de boa-fé houver pago um legado, não está obrigado a prestar o equivalente ao verdadeiro sucessor, ressalvado a este o direito de proceder contra quem o recebeu".

455 “Art. 286. O credor pode ceder o seu crédito, se a isso não se opuser a natureza da obrigação, a lei, ou a convenção com o devedor; a cláusula proibitiva da cessão não poderá ser oposta ao cessionário de boa-fé, se não constar do instrumento da obrigação".

456 “Art. 879. Se aquele que indevidamente recebeu um imóvel o tiver alienado em boa-fé, por título oneroso, responde somente pela quantia recebida; mas, se agiu de má-fé, além do valor do imóvel, responde por perdas e danos".

457 "Art. 896. O título de crédito não pode ser reivindicado do portador que o adquiriu de boa-fé e na conformidade das normas que disciplinam a sua circulação".

458 "Art. 925. Fica desonerado de responsabilidade o emitente que de boa-fé fizer a transferência pelos modos indicados nos artigos antecedentes".

459 “Art. 1.049. O sócio comanditário não é obrigado à reposição de lucros recebidos de boa-fé e de acordo com o balanço".

460 "Art. 1.242. Adquire também a propriedade do imóvel aquele que, contínua e incontestadamente, com justo título e boa-fé, o possuir por dez anos".

461 “Art. 1.259. Se o construtor estiver de boa-fé, e a invasão do solo alheio exceder a vigésima parte deste, adquire a propriedade da parte do solo invadido, e responde por perdas e danos que abranjam o valor que a invasão acrescer à construção, mais o da área perdida e o da desvalorização da área remanescente; se de máfé, é obrigado a demolir o que nele construiu, pagando as perdas e danos apurados, que serão devidos em dobro".

462 "Art. 1.260. Aquele que possuir coisa móvel como sua, contínua e incontestadamente durante três anos, com justo título e boa-fé, adquirir-lhe-á a propriedade". 
especializados, como o www.lexml.gov.br, não indica a existência de decisões ${ }^{463}$ que exijam deveres ou cautelas mínimas para a verificação da boa-fé subjetiva. O silêncio dos órgãos do Poder Judiciário e o conteúdo das proposições prescritivas que versam sobre a matéria indicam que nosso ordenamento jurídico adotou a concepção psicológica da boa-fé subjetiva. Efetivamente, ao se fazer alusão à falta de conhecimento ou ignorância, sem o estabelecimento de deveres ou de diligências indispensáveis, afasta-se a concepção ética desta faceta da boa-fé.

Por relevante, um olhar sobre o Direito estrangeiro, proporcionado por Menezes Cordeiro, indica a adoção da fórmula psicológica pelo Direito francês; de outro bordo, a fórmula ética é encontrada nos Direitos italiano e alemão ${ }^{464}$.

Já na boa-fé objetiva, o ponto de partida é um padrão de conduta comum, do homem médio, considerado o caso fático. Cuida-se de um dever de agir em conformidade com preceitos sociais estabelecidos e reconhecidos. Esse agir pode, ainda, ser compreendido como modelo de conduta social, standard jurídico, segundo o qual cada pessoa deve atuar de maneira correta, honesta, proba e leal ${ }^{465}$.

Não se deve, todavia, confundir o dever de diligência próprio da concepção ética da boa-fé subjetiva com a boa-fé objetiva, uma vez que essa, em singela explicação, se localiza fora do sujeito, manifestando-se especialmente como regra de conduta, ao passo que aquela surge dentro do indivíduo, mas se ampara em deveres de informação ou de indagação, que dependem da verificação concreta e podem ser analisados perifericamente por meio da aferição das proteções conferidas pelo Direito às situações que ele visa a tutelar e, também, a confiança do próprio sujeito ${ }^{466}$.

Os delineamentos da boa-fé objetiva acabam por revelar duas ordens de funções, a ativa e a reativa ${ }^{467}$. A primeira delas possui por característica a existência de deveres que não surgem do acordo de vontade das partes, uma vez que dele não necessitam. Cuidam-se dos chamados deveres laterais, anexos, secundários ou acessórios ${ }^{468}$, que complementam

\footnotetext{
${ }^{463}$ No STJ processo n. ${ }^{\circ}$ REsp 69108 / PR e no STF os processos e n. ${ }^{\circ}$ RE 78711 / PE e RE 76859 / RJ.

${ }^{464}$ CORDEIRO, António Manuel da Rocha e Menezes. Da boa fé no direito civil. Almedina, 2011, pp. 425, 431 ,

${ }^{465}$ COSTA, Judith Martins. A boa-fé no Direito Privado. São Paulo: Revista dos Tribunais, 1999, p. 411.

${ }^{466}$ CORDEIRO, op. cit., pp. 524 e 525.

${ }^{467}$ SIMÃO, José Fernando. Direito Civil: contratos. 2 e.d. 2. reimp. São Paulo: Atlas, 2007, p. 19.

${ }^{468}$ SIMÃO, loc. cit.
} 
os deveres principais ou primários, mas não possuem nenhuma relação de dependência com eles ${ }^{469}$.

Em síntese, esses deveres pretendem tutelar a contraparte de riscos de danos na sua pessoa ou no seu patrimônio. A dificuldade na especificação de todos esses deveres é destacada por doutrinadores como Judith Martins-Costa ${ }^{470}$. Porém, com amparo na obra de Adalberto Pasqualotto ${ }^{471}$, é possível mencionar os seguintes deveres anexos: de segurança, de lealdade, de informação e de cooperação.

O dever de segurança impõe aos contratantes atuações de modo a garantir a integridade dos direitos do outro contratante, em todas as situações em que o vínculo possa oferecer algum risco $^{472}$. Já o dever de lealdade repousa na premissa de que nenhuma das partes deve agir de maneira a produzir prejuízos imotivados à contraparte. Insta observar que o singelo cumprimento do contrato é insuficiente, faz-se necessária a atuação de modo a atender aos interesses comuns ${ }^{473}$. Por outro giro, há o dever de comunicar a contraparte sobre fatos relevantes que digam respeito ao objeto do contrato, cabendo ao detentor do conhecimento ou informação expor ao outro contratante todos os dados relevantes à relação jurídica estabelecida, mesmo que possa prejudicar o detentor da informação ${ }^{474}$. Finalmente, o dever de cooperação consagra a ideia de ajuda entre os contratantes, de maneira que uma parte deve prestar auxílio à outra para a consecução dos fins do contrato, o que acaba por implicar maior chance de conclusão ou de adimplemento da avença.

Além da função ativa, encontramos a função reativa ou de defesa, que é utilizada como exceção por aquele que é injustamente atacado por outra pessoa. As principais reações são a exceptio doli, o venire contra factum propium e a supressio e surrectio $^{475}$.

Segundo Menezes Cordeiro, a exceptio doli consiste no poder dado a uma pessoa de repelir a pretensão do autor por ter este incorrido em dolo ou a possibilidade de paralisar a pretensão de outrem em razão de determinado contraente ter atuado com a consciência ou

\footnotetext{
${ }^{469}$ SIMÃO, José Fernando. Direito Civil: contratos. 2 e.d. 2. reimp. São Paulo: Atlas, 2007, p. 20.

${ }^{470}$ COSTA, Judith Martins. Comentários ao novo Código Civil. V.5, tomo I: Do adimplemento e da extinção das obrigações. 4.e.d. Rio de Janeiro: Forense, 2003, p. 38.

${ }^{471}$ PASQUALOTTO, Adalberto. A boa-fé nas obrigações civis. In: MEDEIROS, Antonio Paulo Cachapuz (org.). O ensino jurídico no limiar do século. Porto Alegre: EDIPUCRS, 1997.

472 SIMÃO, op. cit., pp. 20-21.

473 Ibidem, p. 23.

474 Ibidem, p. 24.

475 Ibidem, p. 26.
} 
com a intenção de induzir ou manter o outro em erro ${ }^{476}$. Ainda, José Fernando Simão esclarece que o Direito não pode privilegiar o sujeito que age com intuito de enganar e ludibriar o outro contratante, mesmo que essa conduta não caracterize vício de consentimento. $\mathrm{O}$ dolo, vício de consentimento, não se confunde com a boa-fé nem mesmo restringe a expressão dolo mencionada na exceptio doli, pois aqui ela tem o sentido de contrária à boa-fée ${ }^{477}$.

Temos, também, como função reativa, o venire contra factum proprium, que pretende proteger as justas expectativas criadas pelas atitudes do contratante, visando a evitar que a conduta adotada seja posteriormente contrariada pelo próprio agente ${ }^{478}$. Temse, assim, a existência de dois comportamentos lícitos separados por um lapso temporal, de modo que o segundo contraria o primeiro e caracteriza o exercício inadmissível de posições jurídicas inconciliáveis.

Outra função reativa é a supressio, que deriva do não exercício de um direito por determinado lapso de tempo, gerando na contraparte a legítima expectativa de ele não mais ser exercido, sem violação da boa-fé ${ }^{479}$. Verificada a supresssio, surge para a contraparte o direito de ter preservada a situação criada, de maneira que nasce um direito que até então não tinha, o qual recebe o nome de surrectio $^{480}$.

Mas as manifestações da boa-fé não cessam com as figuras já descritas, outra de relevo para o presente trabalho, também oriunda da boa-fé objetiva, é a culpa in contrahendo. Ela pretende a produção de efeitos em contratos nulos e foi pensada inicialmente por Jhering, que a compreendia como um instituto da responsabilidade civil pelo qual, havendo nulidade do contrato, uma das partes, que tenha ou devesse ter conhecimento do óbice, deve indenizar a outra pelo interesse contratual violado ${ }^{481} 482$. Judith Martins Costa relata, em texto de 2002, que a culpa in contrahendo, muito embora conhecida em vários ordenamentos jurídicos desde o final do século XIX, teve expansão recente, tornando-se viável, tão somente, a partir do momento em que o Direito das

\footnotetext{
${ }^{476}$ CORDEIRO, António Manuel da Rocha e Menezes. Da boa fé no direito civil. Almedina, 2011, p. 720.

477 SIMÃO, José Fernando. Direito Civil: contratos. 2 e.d. 2. reimp. São Paulo: Atlas, 2007, p. 26.

${ }^{478}$ PASQUALOTTO, Adalberto. A boa-fé nas obrigações civis. In: MEDEIROS, Antonio Paulo Cachapuz (org.). O ensino jurídico no limiar do século. Porto Alegre: EDIPUCRS, 1997, p. 124.

479 SIMÃO, op. cit., p. 28.

${ }^{480}$ Ibidem, p. 30.

${ }^{481}$ CORDEIRO, op. cit., p. 530.

482 TURCO, Claudio. L'interesse negativo nella culpa in contrahendo. Rivista di Diritto Civile. Ano LIII, $\mathrm{n}^{\circ}$ 2 Marzo-Aprile. Padova: CEDAM, 2007, pp. 177-178
} 
Obrigações ultrapassou as fronteiras dos tradicionais postulados individualistas, preponderantes nas codificações oitocentistas, valendo, desde então, de princípios e regras que tutelam a confiança ${ }^{483}$ dos contratantes durante as negociações que antecedem a celebração do negócio jurídico ${ }^{484}$.

Chama atenção o fato de a teoria da culpa in contrahendo imputar àquele que tenha - ou devesse ter - conhecimento do óbice o dever de indenizar, o qual se mostra compatível com as normas jurídicas próprias do Direito Civil, seara em que se pretende, em termos de responsabilidade, também, a restituição das partes ao estado anterior, isto é, sem a repercussão dos danos ${ }^{485}$. Todavia, como já esclarecido, esse raciocínio não é totalmente aplicável à relação regida pelo Direito do Trabalho, em virtude da impossibilidade de se devolver ao obreiro a força despendida e, ainda, em razão da ausência de exata correspondência entre o valor atribuído ao trabalho e o ganho efetivamente auferido com ele por seu explorador, o que não significa, porém, que, nesse ramo especializado, a nulidade do negócio jurídico não implique nenhum efeito.

\footnotetext{
483 “A correlação entre confiança e a boa-fé está, para além do parentesco etimológico em que a boa-fé, na acepção objetiva, caracteriza arquétipo ou standard jurídico, segundo o qual cada pessoa deve ajustar a própria conduta a esse arquétipo, obrando como obraria um homem reto: com honestidade, lealdade, probidade, qualificando, por isto, uma norma de comportamento leal”. In: COSTA, Judith Martins. A Proteção da Legítima Confiança nas Relações Obrigacionais entre a Administração e os Particulares. Revista da FACULDADE DE DIREITO da Universidade Federal do Rio Grande do Sul. Volume 22 - 2002, p. 239.

${ }^{484}$ Ibidem, p. 240.

${ }^{485}$ Karl Larenz afirma acerca da culpa in contrahendo que "trata-se, na assim descrita responsabilidade pela segurança dos clientes (ou dos possíveis clientes) no estabelecimento comercial, na minha opinião, de uma ampliação, conforme o sentido e matéria, da responsabilidade "pré-contratual" por culpa in contrahendo. $\mathrm{O}$ dever de cuidado e proteção ampliado começa, nesses casos, não com a entrada em "negociações contratuais", mas precisamente com o estabelecimento do contato negocial através da entrada no recinto. A opinião segundo a qual se precisaria, em todas as circunstâncias, estar manifestada a vontade de concluir um contrato, deveria ser um resquício da velha concepção segundo a qual a responsabilidade deve partir de um contrato ou, pelo menos, de um negócio jurídico unilateral. O mínimo que essa concepção precisaria exigir era que pelo menos uma parte tenha manifestado uma declaração direcionada à conclusão de um contrato. Depois, contudo, de se ter desfeito a concepção de que se trata de um dever de proteção fundado exclusivamente no direito objetivo, nada impede que se equipare à fattispecie da entrada em negociações a fattispecie do estabelecimento de "contrato social", quando esses fatos típicos forem de tal modo formados que justifiquem uma idêntica responsabilidade. Um tal tipo de fattispecie a ser semelhantemente valorado é, como creio ter demonstrado, a entrada em estabelecimentos comerciais de alguém como cliente ou como possível cliente. Se se deseja incluir esses fatos típicos terminologicamente na responsabilidade por culpa in contrahendo, então pode-se falar de uma "relação obrigacional legal decorrente da negociação contratual ou de outros contratos negociais". Com isso, poderia acontecer aquilo que é correto na teoria do "contato social" sem que se sucedesse a uma ilimitada dilação da responsabilidade de natureza contratual, como se há de temer principalmente quando não se limita essa responsabilidade do proprietário de estabelecimentos comerciais frente aos clientes, não precisamos recorrer ao dever geral de segurança no tráfico, o qual só interessa com base para uma responsabilidade delitual”. In: LARENZ, Karl. Culpa in contrahendo, dever de segurança no tráfico e "contrato social". Revista de Direito Privado. Ano 9, n. 34, abr-jun./2008. Revista dos Tribunais, p. 352.
} 
Menezes Cordeiro, com amparo na jurisprudência alemã, identifica a manifestação da culpa in contrahendo nos deveres de proteção, de esclarecimento e de lealdade, todos incidentes em momento anterior ao da celebração do negócio jurídico ${ }^{486}$. Nota-se que a culpa in cotrahendo estabelece deveres entre os negociantes mesmo antes da formalização de qualquer contrato, porquanto a boa-fé objetiva pretende a adoção de condutas que preservem o tráfego jurídico, a confiança e, em última, que eles analisem a segurança jurídica. Desta feita, é possível afirmar a existência de deveres relativos ao mútuo comportamento ao longo das negociações, deveres de conduta como o de comunicar o outro sujeito da relação jurídica sobre a possibilidade de alteração de quaisquer de seus elementos e, ainda, o de comunicar ao outra eventual causa de invalidade do negócio ${ }^{487}$.

Veja-se que o dever de proteção impõe aos celebrantes a adoção de todas as medidas necessárias a elidir quaisquer possibilidades de danos à outra parte. Idêntica relevância está no dever de esclarecimento, que impede, ou pretende impedir, a prática de atos com amparo em falsas indicações, em informações deficientes ou, até mesmo, em ameaças ilegais. Um terceiro dever emanado da culpa in contrahendo é o dever de lealdade, que não se confunde com as figuras anteriores. É possível compreendê-lo como o comportamento assumido pelas pessoas com o fim de evitar a celebração de negócios nulos.

Para fechar esse tópico, não há dúvidas sobre a incidência ou sobre a inclusão da boa-fé no Direito do Trabalho ${ }^{488}$, o que fornece grande arsenal favorável à imposição à Administração Pública do dever de conceder amplos direitos aos trabalhadores contratados sem prévia aprovação em concurso público, circunstância que competia a ela informar e implementar.

\section{Momentos de incidência da boa-fé.}

A boa-fé, ao pregar o comportamento leal entre os contratantes, acaba por indicar sua vinculação com a solidariedade constitucional, que, por sua vez, está centrada na

${ }^{486}$ CORDEIRO, António Manuel da Rocha e Menezes. Da boa fé no direito civil. Almedina, 2011, pp. 546552.

${ }^{487}$ COSTA, Judith Martins. A Proteção da Legítima Confiança nas Relações Obrigacionais entre a Administração e os Particulares. Revista da FACULDADE DE DIREITO da Universidade Federal do Rio Grande do Sul. Volume 22 - 2002. p. 242.

${ }^{488}$ VIÑA, Jordi Carcía. Buena fe presente em todo el ordenamento jurídico. Julio-Agosto. Madrid: Nueva Imprenta, 2001, pp. 623-625. 
igualdade substancial ${ }^{489}$ verificável na totalidade do Direito. Ademais, ainda que existam distinções econômicas ou técnicas entre os sujeitos do negócio, ambos devem adotar postura que não frustre justas expectativas geradas na contraparte. Com isso, a boa-fé alcança diversas searas do Direito, pois, ao lado da confiança, forma, na sociedade, a base do tráfego jurídico e, em particular, de toda vinculação ${ }^{490}$, o que deixa clara a sua extensão a todas as especialidades alcançadas.

Contudo, o momento a partir do qual a boa-fé influencia os sujeitos do negócio jurídico pode causar dúvidas. O ponto de partida da controvérsia está na redação do art. 422 do Código Civil, vejamos:

“Art. 422. Os contratantes são obrigados a guardar, assim na conclusão do contrato, como em sua execução, os princípios de probidade e boa-fé”.

As proposições prescritivas em realce não fazem nenhuma alusão às tratativas, que antecedem a celebração do negócio jurídico, tampouco às repercussões que sucedem o esgotamento do objeto do ato negocial. O silêncio normativo não pode ser interpretado de modo a elidir a incidência da boa-fé nesses períodos. Isso em razão de a lealdade entre os sujeitos do negócio influenciar a totalidade da relação, e não apenas a execução de seu objeto, como ocorre com o dever de informação e, ainda, com a própria culpa in contrahendo.

Além disso, o amparo constitucional da boa-fé, vale repetir, a segurança jurídica, impõe a observância de seus preceitos em todo o tráfego jurídico, o que inclui as fases pré e pós-negociais ${ }^{491}$.

Nessa dinâmica, a boa-fé abrange todas as obrigações do contrato de emprego, constituindo visão estreita delimitá-la a determinadas obrigações, como a disposição do trabalhador à fiel execução das atividades a ele incumbidas e, no caso do empregador, a

\footnotetext{
489 PIGNATARO, Gisella. Buona fede oggettiva e rapporto giuridico precontrattuale: gli ordinamenti italiana e francese. Pubblicazioni dell’Università degli Studi di Salermo. Napolo: Edizioni Scientifiche Italiane, 1999, p. 48.

490 MARTINS, FLAVIO ALVEZ. A boa-fé objetiva e sua formalização no direito das obrigações brasileiro. 2 e.d. Lumen Juris, p. 8.

${ }^{491}$ Conclusão parecida, muito embora com fundamentos distintos, é encontrada na III Jornada de Direito Civil, promovida pelo Conselho da Justiça Federal, ocorrida nos dias $1^{\circ}$ a 3 de dezembro de 2004: "Enunciado: A boa-fé objetiva deve ser observada pelas partes na fase de negociações preliminares e após a execução do contrato, quando tal exigência decorrer da natureza do contrato".
} 
oferta de atividade e o pagamento de salário ${ }^{492}$.

Por derradeiro, insta esclarecer que a discussão travada no presente tópico restringe-se à boa-fé objetiva, tendo em vista que a subjetiva, ignorância ou crença de não lesar, deve, necessariamente, em razão de suas vicissitudes, estar presente no momento da celebração do negócio jurídico.

\section{Aplicação da boa-fé à Administração Pública.}

Em razão do interesse público ${ }^{493}$ tutelado pela Administração Pública, bem como em virtude da possibilidade de ela intervir e alterar unilateralmente os contratos administrativos, podem surgir dúvidas sobre a aplicação da boa-fé nas relações jurídicas entre ela e o administrado, mesmo que não se cuide de uma relação de Direito Público, como já tivemos a oportunidade de esclarecer.

O ordenamento jurídico pátrio, por meio do art. $54^{494}$ da Lei de Licitações e Contratos Públicos, deixou clara a aplicação dos princípios norteadores da teoria geral dos contratos, o que inclui a boa-fé, à Administração Pública. Em idêntica direção, o art. 59, parágrafo único ${ }^{495}$, do mesmo conjunto de normas, impõe o dever de indenizar os danos causados pela Administração à contraparte, mesmo nos casos em que o contrato é declarado nulo. Por coerência, existindo a previsão de tutela de legítimos interesses singelamente patrimoniais, com muito mais razão devem ser cumpridos ou reparados direitos que se amparam em um dos fundamentos da República, o valor social do trabalho. Em reforço, a Lei do Processo Administrativo Federal previu expressamente a boa-fé como

\footnotetext{
${ }^{492}$ RODRIGUEZ, Américo Plá. Princípios de direito do trabalho: tradução de Wagner D. Giglio. São Paulo: Ltr. Ed. Da Universidade de São Paulo, 1978, p. 277.

${ }^{493}$ Existe entendimento que dividir o interesse público em primário, o interesse da própria sociedade, e secundário, interesse da Administração Público. Com ele não concordamos, uma vez que só se justifica a existência do Estado para a tutela dos interesses dos cidadãos e da própria sociedade, de modo que não existem interesses do próprio Estado, pois supostos interesses, quando contrapostos aos interesses dos cidadãos e da sociedade, refletiriam interesses do administrador público e não da Administração Pública, hipótese que não configura ilícito de per si, mas não merece a qualificação de interesse público.

494 "Os contratos administrativos de que trata esta Lei regulam-se pelas suas cláusulas e pelos preceitos de direito público, aplicando-se-lhes, supletivamente, os princípios da teoria geral dos contratos e a disposições de Direito Privado".

495 “Art. 59. A declaração de nulidade do contrato administrativo opera retroativamente impedindo os efeitos jurídicos que ele, ordinariamente, deveria produzir, além de desconstituir os já produzidos.

Parágrafo único. A nulidade não exonera a Administração do dever de indenizar o contratado pelo que este houver executado até a data em que ela for declarada e por outros prejuízos regularmente comprovados, contanto que não lhe seja imputável, promovendo-se a responsabilidade de quem lhe deu causa".
} 
parâmetro de ação do administrador público, art. $4^{\circ}$, II ${ }^{496}$, e da Administração Pública, como registra o art. $2^{\circ}$, parágrafo único, $\mathrm{IV}^{497}$. Importa esclarecer que foi essa a lei que teve o mérito de introduzir, no universo da Administração Pública, de maneira explícita, o princípio da boa-fé ${ }^{498}$.

Ademais, inexistissem as densificações normativas mencionadas, o princípio da moralidade pública seria suficiente à imposição de deveres à Administração Pública, que decorreriam da lealdade de sua atuação, de modo a não frustrar as expectativas criadas nos cidadãos que com ela se relacionam, preservando, desse modo, a boa-fé na atuação dos entes estatais. Mas não é só, a segurança jurídica emerge do mandamento constitucional consagrado no art. $5^{\circ}, \mathrm{XXXVI}^{499}$, que a tutela, inclusive, contra a atuação do Poder Legislativo, obstando que essa manifestação da soberania viole, com inovações normativas, o direito adquirido, o ato jurídico perfeito e a coisa julgada. Não menos relevante é a norma contida no inciso XXXV do mesmo dispositivo, que se refere à universalidade da jurisdição, segundo o qual é defeso excluir da apreciação do Poder Judiciário qualquer lesão ou ameaça de direito ${ }^{500}$, o que indica a guarida constitucional da segurança jurídica, mesmo que ela ocorra em razão da intervenção do Poder responsável pela aplicação do Direito em litígios.

A boa-fé verificada nas normas acima é a objetiva, isto é, aquela que se refere à adoção de comportamento adequado. Nota-se que essas normas pretendem moldar um padrão objetivo de conduta a ser concretizado pelo intérprete com os olhos voltados às circunstâncias do caso, o que corrobora a ductilidade da boa-fé, bem como a importância da intervenção do aplicador do Direito em sua incidência.

Lado outro, a aplicação da boa-fé à Administração Pública já ocupou as bancadas

\footnotetext{
496 "São deveres do administrado perante a Administração, sem prejuízo de outros previstos em ato normativo:

$(\ldots)$

II - proceder com lealdade, urbanidade e boa-fé".

497 “A Administração Pública obedecerá, dentre outros, os princípios da legalidade, finalidade, motivação, razoabilidade, proporcionalidade, moralidade, ampla defesa, contraditório, segurança jurídica, interesse público e eficiência.

Parágrafo único. Nos processo administrativos serão observados, entre outros, os critérios de:

(...)

IV - atuação segundo padrões éticos de probidade, decoro e boa-fé;”.

498 COSTA, Judith Martins. A Proteção da Legítima Confiança nas Relações Obrigacionais entre a Administração e os Particulares. Revista da FACULDADE DE DIREITO da Universidade Federal do Rio Grande do Sul. Volume 22 - 2002, p. 236.

499 "a lei não prejudicará o direito adquirido, o ato jurídico perfeito e a coisa julgada".

500 “a lei não excluirá da apreciação do Poder Judiciário lesão ou ameaça a direito".
} 
do STF, que se atentou à necessidade de observar seus preceitos nos casos de anulação de atos administrativos, em especial nas hipóteses relacionadas a concurso público, bem como a necessidade de observância do princípio superior da segurança jurídica ${ }^{501}$.

Pode-se sustentar, todavia, que a aplicação da boa-fé às relações jurídicas em que a Administração Pública figure daria ensejo ao conflito entre os princípios da legalidade e da segurança jurídica. Resultaria o conflito da necessidade de se seguirem os estritos termos da lei ou de se abandonarem esses rigores para se prestigiarem a segurança jurídica, a confiança ou, até mesmo, a própria boa-fé.

O princípio da legalidade sempre foi muito caro ao Direito, uma vez que representava limitação à atuação do próprio Estado, de modo a refletir a síntese de uma relação entre o Estado de poder, de sujeição ou de subordinação dos cidadãos. Lado outro, o princípio da segurança jurídica, que acaba por abarcar a confiança jurídica, restringia-se à previsibilidade dos atos estatais.

Contudo, hodiernamente, vislumbra-se a modificação do significado dado à palavra confiança, abandonando-se a compreensão atrelada à previsibilidade e à certeza da atuação da Administração, que, em última análise, levava à observância estrita da lei. Vai além, tem-se que entre o Estado e os cidadãos há uma relação de colaboração, de modo que as promessas e expectativas geradas pela atuação dos administradores públicos devem ser cumpridas e atendidas. As mudanças semântica e dogmática repousam, em grande medida, em compreensões do Estado como um interventor em favor dos interesses dos cidadãos, verdadeira compreensão social, que deixa de enxergar o Estado como um inimigo e a lei como um limitador de sua atuação, para considerá-lo um auxiliar ou cooperador na busca

\footnotetext{
${ }^{501}$ A esse respeito encontramos a decisão proferida no processo.$^{\circ}$ MS 22357 / DF - DISTRITO FEDERAL cuja ementa possui a seguinte redação: "EMENTA: Mandado de Segurança. 2. Acórdão do Tribunal de Contas da União. Prestação de Contas da Empresa Brasileira de Infra-estrutura Aeroportuária - INFRAERO. Emprego Público. Regularização de admissões. 3. Contratações realizadas em conformidade com a legislação vigente à época. Admissões realizadas por processo seletivo sem concurso público, validadas por decisão administrativa e acórdão anterior do TCU. 4. Transcurso de mais de dez anos desde a concessão da liminar no mandado de segurança. 5. Obrigatoriedade da observância do princípio da segurança jurídica enquanto subprincípio do Estado de Direito. Necessidade de estabilidade das situações criadas administrativamente. 6. Princípio da confiança como elemento do princípio da segurança jurídica. Presença de um componente de ética jurídica e sua aplicação nas relações jurídicas de direito público. 7. Concurso de circunstâncias específicas e excepcionais que revelam: a boa fé dos impetrantes; a realização de processo seletivo rigoroso; a observância do regulamento da Infraero, vigente à época da realização do processo seletivo; a existência de controvérsia, à época das contratações, quanto à exigência, nos termos do art. 37 da Constituição, de concurso público no âmbito das empresas públicas e sociedades de economia mista. 8. Circunstâncias que, aliadas ao longo período de tempo transcorrido, afastam a alegada nulidade das contratações dos impetrantes.. Mandado de Segurança deferido."
} 
dos bens jurídicos necessários a uma vida digna ${ }^{502}$.

Essa aproximação de Estado e sociedade, própria de compreensões não liberais ${ }^{503}$, decorre da inserção de direitos fundamentais sociais nas constituições, na codificação dos procedimentos administrativos, na emergência de leis de conduta para os agentes públicos e por meio da concreção judicial de princípios, diretrizes, cláusulas gerais e conceitos indeterminados, que possuem a função de injetar carga valorativa na regulação jurídica dos comportamentos sociais, de modo que o aplicador do Direito não só preenche lacunas, mas também possui funções criativas, modelando a solução de acordo com a hipótese apresentada $^{504}$.

Com efeito, atribuídos novos sentidos semântico e dogmático à confiança ${ }^{505}$ (segurança), tem-se que ela se presta, sob os auspícios da primeira, à exigência de comportamento ético $^{506}$; pela outra, consagra-se à imposição de obrigações àquele que faz promessas ou cria expectativas em outrem. Essas compreensões, reafirma-se, são aplicáveis, inclusive, nos casos em que a Administração, ou, se se preferir, o administrador público, foi quem as propalou.

Nessa linha, o amparo da boa-fé na segurança jurídica ou na confiança, em uma concepção atual da expressão, ultrapassa a ideia de previsibilidade e de certeza dos atos estatais fundados na legalidade, que regia as relações de poder e de subordinação entre o

\footnotetext{
${ }^{502}$ Para Judith Martins-Costa "essa compreensão deriva, dentre outros fatores, de uma mudança ideológica: no Estado Social, muda o pathos que animava o Estado liberal. Do pathos da liberdade se alcança o pathos da solidariedade social, hoje um valor de status constitucional (CF, art. $3^{\circ}$, III, e art. 170). Por detrás dessa mudança está um novo modelo de relacionamento entre Estado e Sociedade Civil: esta não mais refuta a intervenção do Estado, mas verdadeiramente a requer e solicita e a proteção, "como termo correlativo da obediência, resta preenchida de um novo conteúdo: é tutela dos particulares nas concretas necessidades da vida (doença, desemprego, velhice, etc), e não bens longínquos e inapreensíveis como a paz interna e a integridade das fronteiras"'”. In: COSTA, Judith Martins. A Proteção da Legítima Confiança nas Relaçães Obrigacionais entre a Administração e os Particulares. Revista da FACULDADE DE DIREITO da Universidade Federal do Rio Grande do Sul. Volume 22 - 2002. p. 234.

${ }^{503}$ A lei, portanto, deve limitar-se a proteger a esfera individual de liberdade, garantindo a economia privada, de modo a assegurar o pleno funcionamento de um mercado concorrencial e a absoluta previsibilidade de comportamento dos sujeitos públicos e privados.

Esta pretendida estabilidade encontrou seu ápice, no Direito Positivo, no Código de Napoleão de 1804.

Todavia, a necessidade cada vez mais premente de o Estado imiscuir-se na vida dos cidadãos, superando o primeiro momento político, no qual o Governo apenas garantia as liberdades individuais, abstendo-se de intervir, tornou necessário um repensar político do princípio de legitimidade, cujo marco podemos fixar na Constituição de Weimar, de 1917. In: BARROS, José Fernando Cedeno de. Disciplina das Relações Jurídicas Decorrentes de Medida Provisória não Convertida em Lei no Sistema Constitucional Brasileiro. REVISTA DE INFORMAÇÃO LEGISLATIVA. A. 29, n. 115, jul./set. 1992, p. 203.

${ }^{504}$ COSTA, op. cit., p. 235.

505 “A confiança (cum fides) adjetiva-se na boa-fé (bona fides)”. Ibidem, p. 235.

${ }^{506}$ A palavra ética é aqui utilizada no sentido de comportamento leal e concorde com o que se aguarda.
} 
Estado e os particulares ${ }^{507}$. Não é com outro sentido que Juarez Freitas afirma a autonomia e a juridicidade do princípio da boa-fé, ou da confiança, do administrado na Administração

Pública e vice-versa, implicando, necessariamente, o reconhecimento de limites menos formais e mais substancias para a decretação de nulidade de um ato administrativo ${ }^{508}$, bem como, afirmamos nós, na produção de efeitos.

Lado outro, nas relações entre Administração Pública e cidadãos, o que inclui as relações de emprego com a Administração, não se deve privilegiar o poder de império da ação estatal, devendo outros fatores ser levados em consideração, por exemplo, as expectativas geradas em outrem ou na sociedade, que também se qualificam como violações da boa-fé em seu aspecto objetivo. Assim, a Administração está adstrita a

507 Deveras esclarecedores são os dizeres de Judith Martins-Costa no sentido de que "é o que assinala o administrativista espanhol Luciano Parejo Alfonso, para quem cada vez mais freqüente apelo à confiança na relação Estado-cidadão, constitui sintoma da atual insuficiência dos princípios da segurança jurídica e da legalidade para resolver por si mesmo - por sua tensão recíproca - os problemas hoje enfrentados pelo Estado de Direito. O mesmo sintoma já havia sido detectado entre nós por Almiro do Couto e Silva, que em texto dos anos 80 alertava à polaridade entre os princípios da legalidade e da segurança, com a prevalência ora de um, ora de outro, para concretizar o valor essencial da justiça. A doutrina é, aqui, por voz das mudanças, dos quase imperceptíveis câmbios semânticos dos quais o Direito é tecido: pois é justamente a insuficiência dos princípios da legalidade e da segurança que revestirá a nova conotação que vem sendo conferida à confiança, princípio tão antigo que já estava nas bases da formação de Roma. Não que o moderno Estado de Direito não considerasse a confiança um de seus valores. Pelo contrário, os princípios da legalidade e da segurança (dito, também, "princípio da certeza jurídica") têm, tradicionalmente, a proteção da confiança em sua base. No entanto, o termo "confiança", vinha aí, recoberto por uma significação específica: a ideia da previsibilidade e certeza dos atos estatais, na base da qual estavam a radical separação entre a sociedade e o Estado, a relativa estreiteza das funções administrativas, a também relativa estabilidade da produção normativa estatal e a noção segundo a qual as relações entre Estado e particulares seriam, nuclearmente, relações de poder, de sujeição ou subordinação. Nessa perspectiva, a segurança confundia-se com a legalidade estrita: a lei abstrata e geral, minudente em seus comandos, preveria e fixaria o universo dos comportamentos devidos, realizando, assim, o valor justiça. No Direito Privado, por sua vez, as referências iniciais à confiança estavam ligadas à teoria do erro e à teoria da aparência, aí quase se esgotando o seu universo de atuação.

Hoje em dia, diferentemente, o princípio da confiança está na base das relações jurídicas, sejam de direito público ou privado. Domina por inteiro a Teoria do Negócio Jurídico, subvertendo o tradicional fundamento que situava na vontade humana o motor explicativo das relações obrigacionais. (...) Como se vê, o que modifica-se hoje - o câmbio semântico, acima aludido - é a compreensão da palavra "confiança", que passa de um grau de significação a outro. O que agora se quer significar é que a confiança, que é proteção jurídica e postulado ético, para além de constituir pressuposto de toda e qualquer ordem jurídica que se queira como tal - atuando como verdadeiro cimento da convivência coletiva - é, também, uma necessidade desta mesma ordem, necessidade que só tende a crescer à medida em que as relações se tornam distantes e impessoalizadas. (...) No plano dogmático, por sua vez, pela expressão "princípio da confiança" se está hoje a indicar a fonte produtora de deveres jurídicos e o limite ao exercício de direitos e poderes formativos, tendo em vista a satisfação das legítimas expectativas criadas, no alter, pela própria conduta. A expressão assinalada, de um lado a valorização dos pressupostos éticos na ação administrativa, considerando-se a confiança, de um lado, condição sine qua non das ações e das relações que cabe ao Estado dirigir ou coordenar, de outro a sua concreta feição, pois a confiança não é pensável in abstracto, longe das particularidades ações e situações". In: COSTA, Judith Martins. A Proteção da Legítima Confiança nas Relações Obrigacionais entre a Administração e os Particulares. Revista da FACULDADE DE DIREITO da Universidade Federal do Rio Grande do Sul. Volume 22 - 2002, pp. 232-233.

508 FREITAS, Juarez. A anulação dos atos administrativos em face do princípio da boa-fé. Boletim de Direito Administrativo. Ano XI, n. ${ }^{\circ}$ 2, fevereiro, 1995, p. 95. 
conformar suas condutas às normas de comportamento que, mesmo que não possuam assento legal ou em ato administrativo, permitem realizar o interesse público sem o sacrifício da esfera jurídica dos cidadãos.

Segundo Regis Fernandes de Oliveira, o caminhar do Direito Administrativo avança para a consagração de direitos em favor dos indivíduos contra o Estado, deixando de se estudarem prerrogativas do Estado e de se enxergarem os indivíduos como meros pontos de incidência desse direito. Desde então, o Estado passa a ter prerrogativas destinadas ao alcance das finalidades encampadas pelo ordenamento jurídico, de modo a preservar a compatibilidade entre sua existência e a tutela dos interesses dos cidadãos. Logo, nessa vertente, o Estado deve privilegiar a boa-fé do administrado, mesmo que os atos praticados pelo agente administrativos sejam nulos ${ }^{509}$.

Considerando que a segurança jurídica é um dos princípios fundamentais da ordem jurídica constitucional e que, como tal, rege as relações havidas entre Estado e cidadão, o aplicador do Direito deve valer-se de interpretação sistemática para harmonizar os preceitos que, ao menos aparentemente, estão em confronto, primando, em sua exegese, pela harmonização dos princípios da legalidade e da segurança jurídica. Logo, o intérprete não pode desconsiderar a significação de nenhuma norma, sejam regras, sejam princípios, para que se mantenha a inteireza do ordenamento jurídico ${ }^{510} 511$.

A aplicação da boa-fé às relações de emprego havidas entre a Administração Pública e os cidadãos, especialmente em sua vertente objetiva, impõe ao empregador (ente público) os deveres de colaboração, cooperação, consideração com os legítimos interesses do alter, correção, informação, veracidade, lealdade e manutenção de promessas feitas, de não revogação de atos que tenham atingido a esfera de terceiros e, até mesmo, a consideração de eficácia de atos eivados por nulidade ${ }^{512}$.

Desse modo, a proteção da confiança, traduzida nos deveres de agir segundo a

\footnotetext{
${ }^{509}$ OLIVEIRA, Regis Fernandes. A proteção da boa-fé no Direito Administrativo. Revista dos Tribunais. ano 82 - fevereiro de 1993, vol. 688, pp. 268-269.

${ }_{510}$ BREDALGA, Roque. Fato consumado:pressupostos. Direito \& Justiça. REVISTA DA FACULDADE DE DIREITO DA PUCRS. Volume 19 - Ano XX - 1998, p. 33.

511 "A segurança jurídica funciona, assim, como resultado de um conjunto de técnicas normativas encaminhadas a garantir a própria consistência do sistema que tem no fato consumado um dos elos de sustentação". In:MATTOS, Mauro Roberto Gomes de. Princípio do fato consumado no direito administrativo. Revista de Direito Administrativo. 220. I-IV; I-429, abr/jun. Rio de Janeiro, 2000, p. 196.

512 COSTA, Judith Martins. A Proteção da Legítima Confiança nas Relações Obrigacionais entre a Administração e os Particulares. Revista da FACULDADE DE DIREITO da Universidade Federal do Rio Grande do Sul. Volume 22 - 2002. p. 237.
} 
boa-fé e com adstrição à lealdade, implicará limitação a certos poderes da Administração Pública, uma vez que, nas hipóteses em que os órgãos ou autoridades públicas geram, com seus atos no mundo jurídico, o nascimento de expectativas e de direitos, devem ser eles tutelados, o que resulta, por vezes, na impossibilidade de revogar ou revisar atos lícitos, porém inoportunos, e de invalidar atos ilegais, nos casos em que já consolidados pelo tempo decorrido ${ }^{513}$.

Assim, não restam dúvidas sobre a aplicação da boa-fé à Administração Pública.

\section{Violação da boa-fé objetiva pela Administração Pública.}

A Administração Pública é quem oferta os empregos públicos e impõe suas condições, mesmo diante da natureza de negócio jurídico do vínculo estabelecido entre os sujeitos da relação e do reduzido campo de exigências do trabalhador, nada distinto do que ocorre na generalidade dos contratos de emprego. Pode-se dizer, ainda, que é a própria Administração Pública quem possui o amplo domínio do conteúdo não obrigatório da relação de emprego. Assim, aquele que oferta o posto de trabalho, estabelece suas condições gerais e exerce o poder diretivo não deve atuar de modo distinto do comportamento anteriormente adotado. Cuida-se da incidência da proibição do venire contra factum proprium $^{514}$, que qualifica como ilícito o aproveitamento de situações prejudiciais a outrem para a caracterização das quais tenha a Administração agido. Tem-se, dessa maneira, o venire como uma vedação genérica à deslealdade ${ }^{515}$.

Nessa linha, o primeiro ato praticado pela Administração Pública, qual seja, a oferta de emprego, com o estabelecimento de seu conteúdo, configura o factum proprium que vem a ser contrariado por um segundo ato (venire) no caso de não pagamento dos

513 COSTA, Judith Martins. A Proteção da Legítima Confiança nas Relações Obrigacionais entre a Administração e os Particulares. Revista da FACULDADE DE DIREITO da Universidade Federal do Rio Grande do Sul. Volume 22 - 2002, p. 237.

${ }^{514}$ Em nota de rodapé Judith Martins Costa esclarece que "o venire consiste em especificação na antiga Teoria dos Atos Próprios, que independe de recepção legislativo, pois traduz princípio geral que tem como injurídico o aproveitamento de situações prejudiciais ao alter para a caracterização das quais tenha agido, positiva ou negativamente, o titular do direito ou faculdade. Na proibição do venire incorre quem exerce posição jurídica em contradição com o comportamento exercido anteriormente, verificando-se a ocorrência de dois comportamentos de uma mesma pessoa, diferidos no tempo, sendo o primeiro (o factum proprium) contrariado pelo segundo. O princípio atua em todos os "ramos" do Direito, tendo sua raízes (sic) no Direito Romano que, sistematizado no Direito Intermédio, deu causa ao brocardo adversus factum suum quis venire non potest”. Ibidem, p. 238.

${ }^{515}$ COSTA, loc. cit. 
direitos próprios da relação de emprego, o que viola sobremaneira a confiança jurídica.

Em reforço à proibição do venire contra factum proprium, encontramos, para o caso, a figura da culpa in contrahendo, própria da fase pré-negocial. Esse instituto pretende, também, a proteção da confiança depositada por uma das partes na outra ${ }^{516}$. Chama a atenção o dever que possui a parte detentora da informação de comunicar à contraparte acerca de eventual causa de invalidade do negócio jurídico, dever que é acentuado nos casos de desigualdade de poderio entre os sujeitos da relação jurídica, como ocorre nas relações entre Estado e os particulares, pois os órgãos estatais, com seu corpo técnico, ainda que reduzido, são detentores do conhecimento necessário à celebração de negócio jurídico válido, não se esgotando esse dever com o afastamento do silêncio doloso, mas, também, abrangendo o dever de informar lealmente o outro contratante ${ }^{517}$, o que inclusive empolga a atenuação das consequências do nulo, ou sua superação, em ordenamentos jurídicos como o alemão ${ }^{518}$ e sugere a ampla concessão de direitos para os casos de trabalhadores de boa-fé contratados sem concurso público.

Insta pôr em evidência que o dever de informar não encontra incidência nos casos de desconhecimento das leis, uma vez que impera a presunção absoluta de ciência das normas jurídicas de origem estatal, em razão do contido na Lei de Introdução às Normas do Direito brasileiro ${ }^{519}$, o que atinge todos os sujeitos do negócio jurídico, de modo que o dever de informar incide sobre o arcabouço fático ${ }^{520}$. Nessa perspectiva, cabia à Administração Pública, inicialmente, evitar vínculos de emprego sem concurso público, mas, fracassado esse primeiro intento, deveria esclarecer à contraparte sob sua natureza jurídica, de empresa estatal, revelando-se desnecessária, em função da norma destacada supra, informar sobre a exigência de concurso propriamente dita, pois, esclarecidos os fatos anteriores, presume-se, de maneira absoluta, que o trabalhador/administrado o sabia.

É certa, contudo, a existência de situações em que a própria Administração Pública possui dúvidas acerca dos pressupostos do negócio jurídico, como ocorreu com as

\footnotetext{
${ }^{516}$ FAVALE, Rocco. Nullità del contratto per difetto di forma. Rassegna di diritto civile. Saggi. 3/2003, pp. 581 e 586.

517 COSTA, Judith Martins. A Proteção da Legítima Confiança nas Relações Obrigacionais entre a Administração e os Particulares. Revista da FACULDADE DE DIREITO da Universidade Federal do Rio Grande do Sul. Volume 22 - 2002. p. 245.

${ }^{518}$ FAVALE, Rocco. Nullità del contratto per difetto di forma. Rassegna di diritto civile. Saggi. 3/2003, p. 577.

519 “Art. $3^{\text {o }}$ Ninguém se escusa de cumprir a lei, alegando que não a conhece".

${ }^{520}$ FAVALE, op. cit., p. 582.
} 
empresas estatais, no que se refere à admissão de pessoal, antes da decisão do STF, que acabou sedimentando a extensão universal da exigência de prévia aprovação em concurso público para a regular ocupação dos cargos e empregos públicos.

Da somatória dos dizeres anteriores, retira-se que as expectativas geradas no trabalhador por força das promessas realizadas por ocasião das tratativas do negócio e as informações que o administrador público possui e deveria ter passado à contraparte vinculam a Administração Pública, com maior razão diante dos contornos da teoria do órgão, que impõe a essa os atos praticados por aquele ${ }^{521}$, e das extensões do princípio da impessoalidade. Com efeito, o negócio jurídico nulo foi celebrado por obra do próprio Poder Público e estava, pois, investido das presunções de veracidade e de legitimidade que acompanham os atos administrativos, de maneira que o administrado de boa-fé deve desfrutar do resultado de tais atos. Logo, como destaca Celso Antônio Bandeira de Mello, não há dúvida de que os negócios jurídicos inválidos praticados pela Administração devem ser fulminados, impedindo que continuem a desencadear efeitos, mas também não há motivo útil para desconstituir o que se produziu sob o beneplácito do próprio Poder Público nos casos em que o trabalhador/administrado tinha o direito de supor que o fazia regularmente ${ }^{522}$.

Desse modo, resta verificar a boa-fé do trabalhador.

\section{O desconhecimento do trabalhador - boa-fé subjetiva.}

O desconhecimento da natureza jurídica do empregador, que impõe o concurso público como pressuposto formal de validade da admissão de pessoal, constitui pedra de toque para que o trabalhador esteja de boa-fé e, necessariamente, não seja considerado coautor do ilícito administrativo. Apesar da hipossuficiência jurídica do trabalhador, a boafé nas relações de emprego com a Administração deve abranger ambos os polos do negócio jurídico, pois inexiste confusão ou relação de prejudicialidade entre a posição ocupada no contrato e o comportamento leal ou a falta de ciência. Vingasse entendimento diverso, o simples fato de ocupar a posição de empregado em uma relação de emprego seria o suficiente para se caracterizar a boa-fé do sujeito, o que não pode ser admitido, sob pena de

${ }^{521}$ MELlO, Celso Antônio Bandeira de. Curso de Direito Administrativo. 22.ed. São Paulo: Malheiros, 2007, p. 136.

${ }^{522}$ Ibidem, p. 459. 
beneficiarem-se, inclusive, aqueles apadrinhados que prestaram serviços com consciência da ilicitude. Como se demonstrará, oportunamente, a boa-fé deverá ser inferida de indícios extraídos de cada caso.

Veja-se que a produção de efeitos em negócios jurídicos nulos é encontrada de maneira expressa no já mencionado art. 1.561 do Código Civil, que possibilita, em contexto de casamento nulo ou anulável, a produção de efeitos próprios do casamento para o cônjuge que houver contraído o matrimônio de boa-fé, retirando, por outra vertente, a produção de efeitos para o cônjuge de má-fé. Interessa ressaltar que a produção de efeitos em negócios jurídicos nulos ou a relevância da ignorância também é verificada em ordenamentos jurídicos estrangeiros, como o português ${ }^{523}$. Percebe-se, assim, a ampla aceitação legislativa da boa-fé subjetiva com produtora de efeitos jurídicos.

De modo diverso do Direito Comum, o Direito do Trabalho e o Direito Administrativo não possuem previsão acerca da boa-fé subjetiva do trabalhador/administrado em relações de trabalho nulas, o que pode suscitar dúvidas quanto a sua incidência. Em outros dizeres, pode-se questionar se a produção de efeitos decorrentes da boa-fé apenas pode ocorrer quando há expressa previsão legal ou se há cabimento para eles por meio de outros mecanismos do Direito.

É comezinho em Direito que a ausência de normas jurídicas não pode afastar a prestação da tutela jurisdicional. Uma das possíveis alternativas para a hipótese seria a utilização pelo aplicador do Direito da analogia, recurso de integração que principia de uma hipótese não prevista que possua identidade essencial ou fundamental com o fato jurídico que deu origem a dispositivo existente ${ }^{524}$.

Não é outro o entendimento de Menezes Cordeiro, que, ao observar a dificuldade da questão, realça a aplicação da boa-fé subjetiva com um princípio geral, o que permitiria o alcance de situações não especificadas pelo legislador e não representaria nenhuma exceção ou anormalidade, porquanto consagraria manifestação do próprio sistema jurídico

\footnotetext{
${ }^{523}$ De acordo com Maria de Lurdes Pereira "o conhecimento ou desconhecimento de certas circunstâncias são ainda usados para compor as definições de boa ou má fé a que, esporadicamente, a lei recorre. Assim sucede nos arts. $243^{\circ}, n^{\circ} 2,291^{\circ}, n^{\circ} 3,31648^{\circ}$. Esta aproximação legal aconselha a não excluirmos, sem mais, do âmbito do nosso estudo as previsões legais nas quais a boa ou a má fé subjetiva adquirem relevância jurídico-megocial". In: PEREIRA, Maria de Lurdes. Os estados subjetivos na representação voluntária.

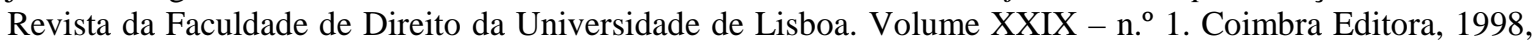
p. 157.

${ }^{524}$ MAXIMILIANO, Carlos. Hermenêutica e aplicação do direito. Rio de Janeiro: Forense, 2008, p. 173.
} 
por meio da aplicação analógica das situações previstas aos casos omissos ${ }^{525}$.

Isso posto, afirma-se que a produção de efeitos com arrimo na boa-fé dá-se não só nos casos em que ocorre expressa previsão, podendo incidir de maneira ampla e independentemente de detalhamento legislativo, com amparo em analogia ou princípio geral, vale dizer, a boa-fé alcança hipóteses outras que não aquelas especificadas pelo legislador, como manifestação que é do princípio constitucional da segurança jurídica. Logo, o desconhecimento do trabalhador, somado à atuação desleal da Administração Pública, é que autoriza a concessão de direitos mesmo se cuidando de relação de emprego havida à margem do concurso público. Pois, afinal, foi a negligência da Administração que trouxe prejuízos ao trabalhador.

Por outro lado, não é de se estranhar que surjam questionamentos acerca do esvaziamento da imperatividade da aprovação em concurso público para a ocupação dos cargos e empregos públicos caso a tese exposta no presente trabalho prevaleça. Pensamos que esse risco não se concretizaria se a concessão ampla de efeitos fosse acompanhada da punição dos administradores públicos responsáveis pelo indevido preenchimento dos postos públicos.

Nota-se que o entendimento consagrado na Súmula $\mathrm{n}^{\circ} 363$ do TST revela-se vantajoso somente à Administração Pública, pois, mesmo sendo a verdadeira responsável pela nulidade do contrato, ela se aproveita do trabalho e paga restritíssimas parcelas, o que, ao contrário de tornar inconveniente a repetição da inconstitucionalidade, a deixa mais atrativa, ao menos sob o aspecto econômico, em prejuízo do trabalhador.

Diante dessa ordem de ideias, não é a concessão de direitos que vilipendia a CR, mas a ausência de punição dos administradores que, a pretexto de protegerem a Carta Política, negligenciam direitos em uma relação jurídica qualificada como nula em razão de suas atuações desatentas à boa-fé objetiva.

Assim, a responsabilização do administrador público revela-se como o meio adequado ao combate da prática reiterada de contratações ao arrepio do concurso público. É certo, ademais, que o trabalhador de má-fé, verdadeiro coautor do ilícito, igualmente, deve sofrer as censuras aplicadas ao administrador. É justamente nesse ponto que se

\footnotetext{
${ }^{525}$ CORDEIRO, António Manuel da Rocha e Menezes. Da boa fé no direito civil. Almedina, 2011, pp. 524 e
} 525 . 
justifica a ampla produção de efeitos em relações de emprego nulas em que o trabalhador está de boa-fé e a cabal ausência de efeitos para o trabalhador de má-fé, pois aquele aparece como vítima, mas esse, como corresponsável pela violação.

Logo, faz-se necessário o manejo da Lei de Improbidade Administrativa.

\section{Ação de improbidade administrativa: o caminho moralizante.}

O combate à prática de contratação de trabalhadores sem a observância do concurso público é explicitado de forma clara pela CR. Encontra-se no Texto Maior a imposição de se responsabilizar o administrador público nos casos em que há violação da norma prevista no art. 37 , II. Cuida-se do $\S 2^{\circ}$ do mesmo artigo, cuja literalidade prevê “ $a$ não observância do disposto nos incisos II e III implicará a nulidade do ato e a punição da autoridade responsável nos termos da lei”. Coube à Lei no 8.429/1992, alcunhada de Lei de Improbidade Administrativa, discriminar diversas condutas que se enquadram como ímprobas e as penalidades correspondentes.

Cumpre, de início, esclarecer quem são aqueles que podem se sujeitar às sanções da Lei de Improbidade Administrativa. Seu art. $1^{0526}$ faz menção ao agente público, servidor ou não, como sujeito ativo do ilícito administrativo, o que pode aparentar que os particulares seriam excluídos de sua abrangência, entendimento que é, todavia, afastado pela clareza do art. $3^{0527}$. Ora, a inclusão dos particulares é de fundamental importância para que a probidade pública seja preservada, porquanto são interesses de sujeitos excluídos da estrutura pública que motivam o cometimento de infrações. No caso de trabalhadores de má-fé, que violam, conscientemente, a regra do concurso público, não há nenhuma dificuldade, pois a redação do art. $1^{\text {o }}$ inclui aqueles que atuam para a Administração Pública, mesmo sem ocupar formalmente a posição de servidor público.

Interessa alumiar que serão autores do ato de improbidade, na esteira do acima

\footnotetext{
526 “Os atos de improbidade praticados por qualquer agente público, servidor ou não, contra a administração direta, indireta ou fundacional de qualquer dos Poderes da União, dos Estados, do Distrito Federal, dos Municípios, de Território, de empresa incorporada ao patrimônio público ou de entidade para cuja criação ou custeio o erário haja concorrido ou concorra com mais de cinqüenta por cento do patrimônio ou da receita anual, serão punidos na forma desta lei”.

527 “As disposições desta lei são aplicáveis, no que couber, àquele que, mesmo não sendo agente público, induza ou concorra para a prática do ato de improbidade ou dele se beneficie sob qualquer forma direta ou indireta".
} 
dito, o administrador público e o trabalhador que deliberadamente violarem os preceitos do concurso público, ambos como agentes públicos (art. $1^{\circ}$ ), o que inclusive foi sugerido pelo Ministro Ricardo Lewandowski do STF por ocasião do julgamento do RE 596478. Esses dizeres têm o propósito de fundamentar a não concessão de direitos ao trabalhador de máfé e, inclusive, amparar a necessidade de ser restituído ao erário todo e qualquer valor por ele recebido, uma vez que uma conduta não pode ser simultaneamente lícita e ilícita pela ordem jurídica, preceito básico para que se mantenha sua coerência.

De acordo com Fabiano Holz Beserra, a prática tem revelado que o sujeito ativo dos atos de improbidade são, por excelência, os agentes públicos responsáveis pela gestão de pessoal e de $\operatorname{contratos}^{528}$. Isso não ocorre por acaso, considerando que os chefes do Poder Executivo concentram grandes atribuições e poderes para determinação da estrutura subjetiva da Administração e, não raras vezes, a realizam à margem das determinações constitucionais e legais, voltados à satisfação de interesses outros.

Ainda inseridos na temática dos sujeitos passivos, destacamos que a composição do STF em 2007 entendeu pela inaplicabilidade da Lei de Improbidade Administrativa aos agentes políticos sujeitos a normas especiais de responsabilidade, nomeadamente ao disposto no art. 102, I, “c", da CR. Entendeu o Pretório Excelso, no julgamento da Reclamação 2.138/DF, pela existência de dois regimes distintos de responsabilidade, o previsto no art. $37, \S 4^{\circ}$, da CR, e o previsto no art. 102 , I, “c”, CR, de maneira que este constitui norma específica que se aplica apenas aos agentes políticos, a outra, aos demais agentes públicos.

Desse modo, embora todos os agentes públicos estejam sujeitos a regime de responsabilidade, nem todos se submetem à Lei de Improbidade Administrativa.

Constituindo o desrespeito ao concurso público ato atentatório aos princípios da Administração Pública ${ }^{529}$, sua reprimenda está prevista no art. 12 , III, da Lei $\mathrm{n}^{\circ}$

\footnotetext{
${ }^{528}$ Ação civil pública e relações de trabalho: tutela da moralidade e da probidade administrativa. Rio de Janeiro: Forense. São Paulo: Método. 2008, p. 67.

529 “Art. 11. Constitui ato de improbidade administrativa que atenta contra os princípios da administração pública qualquer ação ou omissão que viole os deveres de honestidade, imparcialidade, legalidade, e lealdade às instituições, e notadamente:

(...)

V - frustrar a licitude de concurso público”.
} 
$8.429 / 1992^{530}$, que impõe o ressarcimento integral do dano, se houver, além de perda da função pública, suspensão dos direitos políticos, de três a cinco anos, pagamento de multa civil, equivalente a até cem vezes o valor da remuneração percebida pelo agente, e proibição de contratar com o Poder Público ou de receber benefícios ou incentivos fiscais ou creditícios, direta ou indiretamente, ainda que por intermédio de pessoa jurídica da qual seja sócio majoritário, pelo prazo de três anos. Nota-se que entre as sanções está o ressarcimento integral do dano e o pagamento de multa civil de até cem vezes o valor da remuneração recebida, o que torna ilícito todo valor recebido pelo trabalhador de má-fé. Logo, tanto o trabalhador de má-fé quanto o administrador público devem ser punidos, medidas que parecem adequadas a desestimular a prática hodierna da violação do concurso público.

No que se refere à competência para processar e julgar as ações de improbidade, não se encontra no rol estabelecido pelo art. 114 da CR, norma que congrega as competências da Justiça do Trabalho, nenhuma indicação de que ações dessa estirpe se submetam ao jugo da Justiça Especializada. Assim, por exclusão, a competência repousa na Justiça Comum, seja a Federal, seja a Estadual, sempre de acordo com as normas que lhe atribuem competência.

Alice Monteiro de Barros destaca que a responsabilidade civil do administrador público perante a administração não é de competência da Justiça do Trabalho ${ }^{531}$. Não é outro o entendimento que se extrai da jurisprudência do TST, como indicam os julgados proferidos nos processos $n^{\mathrm{o}} 78040-52.2005 .5 .08 .0105^{532}$, da $4^{\mathrm{a}}$ Turma, $\mathrm{n}^{\mathrm{o}}$ 0000-

\footnotetext{
530 “Art. 12. Independentemente das sanções penais, civis e administrativas previstas na legislação específica, está o responsável pelo ato de improbidade sujeito às seguintes cominações, que podem ser aplicadas isolada ou cumulativamente, de acordo com a gravidade do fato:

(...)

III - na hipótese do art. 11, ressarcimento integral do dano, se houver, perda da função pública, suspensão dos direitos políticos de três a cinco anos, pagamento de multa civil de até cem vezes o valor da remuneração percebida pelo agente e proibição de contratar com o Poder Público ou receber benefícios ou incentivos fiscais ou creditícios, direta ou indiretamente, ainda que por intermédio de pessoa jurídica da qual seja sócio majoritário, pelo prazo de três anos".

${ }^{531}$ BARROS, Alice Monteiro de Barros. Curso de direito do trabalho. 7. ed. São Paulo: LTr, 2011, p. 421.

532 "AGRAVO DE INSTRUMENTO. INCOMPETÊNCIA DA JUSTIÇA DO TRABALHO. AÇÃO DE IMPROBIDADE ADMINISTRATIVA. PREFEITO. CONTRATAÇÃO IRREGULAR. I - Analisando a fundamentação do acórdão regional, verifica-se que a causa de pedir e o pedido não se assentam em alegada relação de emprego, porque, na verdade, se origina de contratação irregular sob o regime temporário, com base em Lei Estadual, sendo esta Justiça Especializada, assim, incompetente para dirimir a controvérsia e declarar a efetiva natureza da relação jurídica que vinculou as partes no curso do contrato. II - Isso porque a ação ajuizada por servidor público contratado por prazo determinado, para "atender necessidade temporária de excepcional interesse público", nos termos do artigo 37, IX, da Constituição Federal de 1988, sob o argumento de que houve fraude na contratação sucessivamente prorrogada, enquadra-se numa pretensão não
} 
72.2006.5.12.0041 ${ }^{533}$, da $5^{\text {a }}$ Turma, e $n^{\text {o }} 112900-62.2005 .5 .12 .0010^{534}$, da $7^{\text {a }}$ Turma.

Em suma, o caminho moralizante passa, necessariamente, pela cessação de todo e qualquer vínculo que não tenha observado o concurso público e pela aplicação, ao administrador público responsável pela contratação e ao trabalhador de má-fé, das penas de improbidade administrativa, litígio que não recai sobre a competência da Justiça do Trabalho.

de reconhecimento de vínculo de emprego, mas de julgar prefeito municipal por ato de improbidade administrativa, em decorrência do qual se afasta a competência da Justiça do Trabalho para dirimir controvérsia acerca da existência ou não de vínculo de emprego entre as partes de uma relação de trabalho, por injunção do inciso I do art. 114 da Constituição Federal de 1988, com a redação da Emenda Constitucional n ${ }^{\circ}$ 45/2004. III - Agravo desprovido".

533 "RECURSO DE REVISTA. AÇÃO DE IMPROBIDADE ADMINISTRATIVA. COMPETÊNCIA MATERIAL DA JUSTIÇA DO TRABALHO. A jurisprudência desta Corte vem-se firmando no sentido de que a Justiça do Trabalho não tem competência para o julgamento de prefeitos por ato de improbidade administrativa, mesmo que o suposto ato decorra da contratação de servidores sem prévia realização de concurso público. Recurso de revista não conhecido".

534 "RECURSO DE REVISTA. MINISTÉRIO PÚBLICO DO TRABALHO DA $12^{\mathrm{a}}$ REGIÃO. CONTRATAÇÃO DE SERVIDORES PÚBLICOS. AUSÊNCIA DE CERTAME PÚBLICO. ATO DE IMPROBIDADE ADMINISTRATIVA. INCOMPETÊNCIA DA JUSTIÇA DO TRABALHO. O entendimento desta Corte é no sentido de que a Justiça do Trabalho é incompetente para processar e julgar ação de improbidade administrativa em face de prefeito, vice-prefeito e outros agentes públicos, ainda que o ato praticado seja de contratação de servidor sem submissão a concurso público, conforme exige o artigo 37, II, da Constituição Federal. Tal entendimento se deve ao fato de que a competência de que trata o artigo 114, I, da Constituição Federal diz respeito às ações movidas contra a administração pública direta e indireta, na qualidade de pessoas jurídicas, razão pela qual nele não se incluem os agentes políticos, aos quais não se pode imputar a responsabilidade objetiva pelos atos administrativos, com base no Princípio da Impessoalidade. Recurso de revista de que não se conhece". 


\section{A PROVA DA BOA-FÉ.}

\section{A relevância da prova da boa-fé.}

Tivemos a oportunidade de destacar os fundamentos pelos quais entendemos que a boa-fé deve ser utilizada como instrumento para se determinar a ampla ou a restrita oferta de direitos aos trabalhadores que figurem em uma relação de emprego nula em razão da ausência de concurso público.

Foi, também, em páginas precedentes, que se esclareceu que para as relações de emprego com a Administração Pública em que se preteriu o concurso público verifica-se, ou pode se verificar, uma dupla incidência da boa-fé, na pessoa do trabalhador, administrado, e na pessoa do administrador público, que, em geral, detém as informações necessárias a abster a celebração do negócio jurídico nulo.

Portanto, a ampla produção de efeitos no contrato de emprego nulo está ligada à prova de que o trabalhador desconhece a natureza jurídica de seu empregador e, ainda, à violação dos deveres de lealdade pelo empregador. A maior dificuldade repousa na prova da ignorância obreira, uma vez que as condutas patronais desleais podem ser verificadas pela própria oferta de emprego em que não se esclarece ao trabalhador a natureza jurídica de sua empregadora, o que, no caso da Administração Pública, traria a necessidade de aprovação em concurso público.

Temos, desse modo, que o maior obstáculo para a produção de efeitos no contrato de emprego nulo por meio da intervenção do Estado-juiz em uma relação processual é a prova da boa-fé, especificamente em seu aspecto subjetivo, no que se refere ao trabalhador. Não se trata, contudo, de desafio novo, com o qual os aplicadores do direito não estejam acostumados, pois encontramos na doutrina ${ }^{535}$ diversos exemplos em que a

\footnotetext{
535 Jônatas Milhomens, com amparo no Código Civil de 1916, destaca os seguintes exemplos: "No Direito Privado, exerce função social, ora criadora, ora de convalidação de ato jurídico, função social, inequívoca. $\mathrm{O}$ casamento anulável, ou mesmo nulo, produz efeitos civis se contraído de boa-fé (Código Civil, art. 221). O que semeia, planta, ou edifica em terreno alheio, perde em proveito do dona as sementes, plantas ou construções (superfícies solo cedit). Mas terá direito a indenização se tiver procedido de boa-fé (art.547). Aquelê que por 20 anos, sem interrupção, nem oposição, possuir como seu imóvel adquirir-lhe-á o domínio, independentemente de título de boa-fé, que em tal caso se presume (art. 550). A boa-fé exerce função criadora na especificação (art. 612); função liberatória no contrato de sociedade (art. 1.404); validatória de
} 
boa-fé é fundamental à produção de efeitos na relação jurídica eivada de nulidade, tais como nas hipóteses de aplicação da teoria da aparência aos institutos do casamento, da sociedade, da capacidade, do credor e do regime de bens.

Além dos exemplos acima, próprios do Direito Comum, mostre-se possível a utilização da boa-fé em outras searas, como a trabalhista, em que o instituto, sendo também um de seus princípios, impõe obrigações acessórias aos contratantes e - como defendido nesse trabalho - pode fundamentar o pagamento amplo de direitos trabalhistas nos casos de relações de emprego celebradas ao arrepio dos pressupostos de validade.

Logo, é a formação do convencimento judicial acerca da ignorância do indivíduo, que é a própria boa-fé em sua concepção subjetiva, que possibilitará a produção de efeitos no negócio jurídico nulo.

Resta, pois, perquirir como se prova esse estado de ignorância, ou a boa-fé, em juízo, o que nem sempre será tarefa simples, conforme se demonstrará.

\section{Conceito e objeto de prova.}

No campo processual, a palavra prova possui diversos significados. Utiliza-se com o sentido de meio de prova, ou seja, significando os diversos elementos produzidos com o fim de estabelecer a existência de certos fatos no processo. Entende-se, também, como a ação de provar, que representa a atuação dos sujeitos do processo com o fim de confirmar a existência, ou não, de alegações fáticas realizadas no processo. Por fim, prova representa o fenômeno psicológico produzido no Juiz, por força dos elementos trazidos ao processo, que lhe traz convicção a respeito das alegações fáticas que subsidiam a lide 536537 .

atos ajustados em nome do mandante pelo mandatário, depois de extinto o mandato (artigo 1.321). Segurador e segurado são obrigados a guardar no contrato "a mais estrita boa-fé e veracidade" (art. 1.443). Interpretamse as cláusulas do contrato mercantil de modo que a inteligência simples e adequada, "que fôr mais conforme à boa-fé”, prevaleça à rigorosa e estrita significação das palavras (Código Comercial, art. 131, 1). O mandatário é obrigado a cumprir o mandato empregando a mesma diligência que costuma empregar na gerência dos próprios negócios o "comerciante ativo e probo" (art. 142). O comissário é responsável pela perda ou extravio de fundos de terceiro existentes em seu poder, se não provar que na guarda empregou a diligÊncia que em casos semelhantes empregam os "comerciantes acautelados" (art. 181). In: MILHOMENS, Jônatas. Da presunção de boa-fé no processo civil. $1^{\mathrm{a}}$ ed. Forense, 1961, p. 12 e 13.

536 DELLEPIANE, Antonio. Nova teoria da prova. Tradução da 5. ${ }^{a}$ edição Argentina por Érico Maciel 2. edição. José Konfino - Editor. Rio de Janeiro, 1958, pp.19 e 20.

537 ROSENBERG, Leo. Tratado de derecho procesal civil. Tradução de Ângela Romera Vera. Tomo II. Libro segundo: el procedimento de sentencia. Buenos Aires: Ediciones Jurídicas Europa-America, 1955, p. 201. 
A melhor maneira de identificar e justificar a escolha da concepção ou das concepções de prova que se adotará está na identificação dos fins do presente capítulo. Busca-se, com ele, realçar alguns aspectos probatórios atrelados à boa-fé. Com isso, as concepções por nós adotadas acerca do conceito de prova, apesar de não serem as únicas existentes, dizem respeito ao objeto da prova, aos meios que podem ser empregados no reconhecimento da existência, ou não, das alegações fáticas realizadas pelas partes e, por fim, ao ônus da prova.

\section{Como diretriz geral, a prova tem como objeto os fatos 538539 .}

Outrossim, não se pode olvidar que a boa-fé, tal como abordada no presente trabalho, refere-se ao seu aspecto fático, isto é, à ignorância do vício que macula a validade do negócio jurídico pelo trabalhador-administrado e a adoção de práticas pelo empregadorAdministração que causam expectativa de lisura no candidato ao posto de trabalho público. Diferentemente das práticas do administrador, aferíveis por condutas positivas e objetivas, o desconhecimento ou a ignorância alegada pelo trabalhador é altamente subjetiva ${ }^{540}$, o que dificulta sua prova diretamente, remetendo à utilização da prova indiciária, peculiaridade que se enfrentará em momento apropriado ${ }^{541}$.

Oportunamente, foi esclarecida a natureza fática da boa-fé subjetiva, que traduz a ignorância de determinadas circunstâncias por algum dos sujeitos da relação jurídica. Notase, com isso, que o estado de ignorância deve ser objeto de prova nos processos em que se pretenda a produção de efeitos por atos nulos.

\footnotetext{
${ }^{538}$ Leo Rosenberg afirma que: “Objeto de prueba son, por lo regular, los hechos, a veces las máximas de experiencia, rara vez los preceptos jurídicos (...) Hecho, en este sentido, es todo lo que pertence a la tipicidad de los preceptos jurídicos aplicables y forma la proposición menor del silogismo judicial: son los acontecimentos y el tiempo, pasados y presentes, del mondo exterior y de la vida anímica humana que el derecho objetivo há convertido em presupuesto de un efecto jurídico". In: ROSENBERG, Leo. Tratado de derecho procesal civil. Tradução de Ângela Romera Vera. Tomo II. Libro segundo: el procedimento de sentencia. Buenos Aires: Ediciones Jurídicas Europa-America, 1955, p. 209.

${ }^{539}$ Para Moacyr Amaral Santos "dir-se-à que, às vezes, se torna preciso fazer a prova de uma lei ou mesmo de um costume. Na verdade, isso acontece quando se alega direito estadual, municipal ou costumeiro, singular ou estrangeiro, casos em que deverão ser provados o teor e a vigência. Mas nem por isso, nem porque se trata de provar o teor e a vigência de uma lei ou de um costume, o objeto da prova deixa de ser o fato: na hipótese, é o fato da existência - ou sejam o teor e a vigência da lei ou costume". In: SANTOS, Moacyr Amaral. Prova Judiciária no Cível e Comercial. Volume I. Max Limonad, p. 10.

${ }^{540}$ Alípio Silveira professa a possibilidade de a boa-fé ser objeto de prova ao destacar que "a bôa fé, encarada sob o aspecto psychologico, constitue no direito uma questão de prova”. In SILVEIRA, Alípio. A Bôa Fé no Direito Civil. Typ. Paulista, 1941, p. 39.

541 Interessa relevar, por ora, que a comprovação do fato da boa-fé poderá decorrer de confissão, de documentos de que se extraia a ciência da parte a respeito do vício, ou até mesmo de testemunhas, hipóteses em que ocorrerá de maneira direta a prova do fato da boa-fé.
} 
É certo que a boa-fé subjetiva incide em diversas searas do Direito, o que faz coincidir, em todas elas, um dos fatos a serem provados, qual seja, a ignorância. Apesar da identidade, os questionamentos realizados variarão de acordo com o contexto em que se pretenda a produção de efeitos com arrimo na boa-fé, em virtude da multiplicidade de circunstâncias que podem indicar o grau de cognição do indivíduo a respeito dos fatos ou pressupostos que maculam o negócio jurídico.

De todo modo, o ponto de início deve ser a identificação do pressuposto de validade supostamente ignorado pelo sujeito e, a partir dele, a atividade instrutória deverá ser conduzida de maneira que se apure a verdade a respeito do fato em destaque.

Com isso, temos que, no casamento putativo ${ }^{542} 543544$, o pressuposto ausente pode ser a capacidade, a ausência de impedimento, a idade mínima, o vício de vontade, o mandato revogado ou a incompetência da autoridade celebrante; no credor putativo ${ }^{545}$, falta a condição de credor do pagamento; na ausência de concurso público ${ }^{546}$, o desconhecimento da natureza jurídica do empregador, que traz a reboque a exigência do concurso público para a válida contratação de pessoal.

Por meio da prova, procura-se averiguar a veracidade dos fatos alegados pelas partes. Moacyr Amaral Santos ensina que provar nada mais é do que fornecer a

\footnotetext{
542 “Código Civil. Art. 1.548. É nulo o casamento contraído: I - pelo enfermo mental, sem o necessário discernimento para os atos da vida civil; II - por infringência de impedimento".

543 "Código Civil. Art. 1.550. É anulável o casamento: I - de quem completou a idade mínima para casar; II - do menor em idade núbil, quando não autorizado por seu representante legal; III - por vício de vontade, nos termos dos arts. 1.556 a 1.558; IV - do incapaz de consentir ou manifestar, de modo inequívoco, o consentimento; V - realizado pelo mandatário, sem que ele ou o outro contraente soubesse da revogação do mandato, e não sobrevindo coabitação entre os cônjuges; VI - por incompetência da autoridade celebrante. Parágrafo único. Equipara-se à revogação a invalidade do mandato judicialmente decretada".

544 "Código Civil. Art. 1.561. Embora anulável ou mesmo nulo, se contratado de boa-fé por ambos os cônjuges, o casamento, em relação a estes como aos filhos, produz todos os efeitos até o dia da sentença anulatória. § 1. ${ }^{\circ}$ Se um dos cônjuges estava de boa-fé ao celebrar o casamento, os seus efeitos civis só a ele e aos filhos aproveitarão. $§ 2 .^{\circ} \mathrm{Se}$ ambos os cônjuges estavam de má-fé ao celebrar o casamento, os seus efeitos civis só aos filhos aproveitarão".

545 "Código Civil. Art. 309. O pagamento feito de boa-fé ao credor putativo é válido, ainda provado depois que não era credor".

546 “Constituição da República. Art. 37. A administração pública direta e indireta de qualquer dos Poderes da União, dos Estados, do Distrito Federal e dos Municípios obedecerá aos princípios da legalidade, impessoalidade, moralidade, publicidade e eficiência e, também, ao seguinte; I - os cargos empregos e funções públicas são acessíveis aos brasileiros que preencham os requisitos estabelecidos em lei, assim como aos estrangeiros, na forma da lei; II - a investidura em cargo ou emprego público depende de aprovação prévia em concurso público de provas ou de provas e títulos, de acordo com a natureza e a complexidade do cargo ou emprego, na forma prevista em lei, ressalvadas as nomeações para cargo em comissão, declarado em lei de livre nomeação e exoneração;".
} 
demonstração da existência, ou inexistência, de um fato, bem como que haja, ou não, existido de um determinado modo e não de outro ${ }^{547}$.

É na sentença que o Estado diz o direito aplicável ao caso. Esse ato do juiz pode ser visto como um silogismo em que os fatos constituem a premissa menor e o direito, a premissa maior, sendo que ambas amparam uma conclusão. Nessa linha, apenas os fatos controvertidos e relevantes para o convencimento judicial precisam ser provados, dispensando-se a atuação probatória quanto aos fatos afirmados por uma parte e confessados pela outra parte, os fatos não contestados e os fatos notórios.

Essa diretriz processual ampara-se no princípio da celeridade e na lógica, uma vez que, incontroverso um fato, o dispêndio de tempo e o consumo de recursos na sua reafirmação seria inútil ${ }^{548}$. Todavia, ela não obsta que o juiz, como destinatário da prova e condutor do processo, possa determinar a produção de provas para os fatos que não lhe pareçam verossímeis, ainda que incontroversos.

No caso da boa-fé, mesmo que a parte ocupante do polo passivo esteja de acordo com a alegação do estado de ignorância do ex adverso quanto aos vícios que maculam a hígida prática de qualquer negócio jurídico, especialmente quando se trata de lide acerca de efeitos de ato nulo, o juiz, como responsável pela consecução do escopo jurídico do processo, qual seja, dar atuação à vontade concreta de lei ${ }^{549}$, deve adotar as medidas necessárias à descoberta da verdade, porquanto não se cuida de mero espectador que deva aceitar passivamente as alegações realizadas pelas partes em aparente desconformidade com a lei ou em possível conluio para alcançar fim vedado pelo ordenamento.

Em suma, o juiz tem liberdade para conduzir a instrução do processo, devendo restringir-se, em um primeiro momento, aos fatos controvertidos e relevantes para a solução do conflito, mas, ao sinal de ausência de verossimilhança das alegações, deve o

\footnotetext{
${ }^{547}$ SANTOS, Moacyr Amaral. Prova Judiciária no Cível e Comercial. Volume I. Max Limonad, p. 221.

${ }^{548}$ Ibidem, p. 223.

${ }^{549}$ Segundo Cândido Rangel Dinamarco: "excluída a integração do sistema processual no lavor de criação das situações jurídicas de direito material e tendo-se por demonstrada a tese dualista do ordenamento jurídico, chega-se com naturalidade ao reconhecimento de que o escopo jurídico na jurisdição não é a composição das lides, ou seja, o estabelecimento da regra que disciplina e dá solução a cada uma delas em concreto; a regra do caso concreto já existia antes, perfeita e acabada, interessando agora dar-lhe efetividade, ou seja, promover sua atuação. O escopo de atuação da vontade concreta da lei é tão intimamente ligado à tese dualista, que por expressivos defensores desta fórmula assim construída tem sido apontada também como uma das características fundamentais da própria jurisdição (ao lado do caráter substitutivo)". In: DINAMARCO, Cândido Rangel. A instrumentalidade do processo. 14. ${ }^{\mathrm{a}}$ ed. revista e atualizada. São Paulo: Malheiros, 2009, p. 246.
} 
magistrado buscar esclarecê-los, notadamente quando se está em perigo a observância de regras constitucionais de proteção ao interesse público.

Ocorre que, nem sempre existem meios de prova que permitam atestar de maneira direta o grau de conhecimento daquele que alega estar de boa-fé. Em tais casos, é necessária a prova de outros fatos que permitam esclarecer o fato principal, verdadeiramente relevante para a solução do caso.

Assim, não sendo possível a confissão do envolvido sobre a ciência do vício que maculava a validade da contratação e inexistindo meios de prova que possibilitem identificá-la, será necessária, por força da já mencionada subjetividade da boa-fé, a comprovação de fatos outros que permitam concluir pela existência de boa ou má-fé.

É o que a doutrina classifica de prova direta ou indireta ${ }^{550}$.

O fundamento dessa separação repousa na coincidência ou na divergência entre o fato objeto de prova e o fato objeto da alegação ${ }^{551}$ : tem-se a prova direta quando há correspondência entre eles e prova indireta quando não há essa identidade.

É interessante observar, no caso da prova indireta, que o fato alegado, caso analisado isoladamente, pode parecer irrelevante, mas, analisado no contexto lógico do processo, pode constituir prova de fatos relevantes. Nessa ordem de ideias, é que surgem os indícios, especificamente na distinção entre o fato alegado e aquele que se pretende provar.

Com isso, é possível destacar, ainda dentro da identificação do objeto da prova, uma distinção entre a comprovação das alegações fáticas a respeito do objeto do processo propriamente dito e a de circunstâncias indiciárias que permitam, por inferência, o reconhecimento de fatos que se ligam diretamente ao objeto do processo. Contudo, o

${ }^{550}$ LOMBARDO, Luigi. La prova giudiziale: contributo alla teoria del giudizio di fatto nel processo. Università di Catania. Publicazioni della Facoltà di Giurisprudenza. Giuffrè editore, 1999, p. 316.

${ }^{551}$ Para Francesco Carnelutti "Il critério della distinzione riguarda dunque soltanto la coincidenza o la divergenza tra il fatto da provare e il fatto che cade sotto $i$ sendi del verificatore e gli server per la formazione del giudizio. Quando la prova è indiretta trai 1 soggeto e l'oggetto si interporne un terzo elemento, al quale si dà il nome di mezzo o fonte di prova; brevemente, per indicarlo, si dice anche soltanto prova". In: CARNELLUTI, Francesco. Sistema di diritto processuale civile. I - funzione e composizione del processo. Padova: Cedam, 1936, p. 678. 
esclarecimento de fatos por inferência não torna o indício meio de prova, cuida-se, sim, de fato que por meio de ilação possibilitará o esclarecimento de outros 552553 .

Moacyr Amaral Santos indica a aplicação da prova indiciária na apuração do dolo, da fraude, da simulação, da má-fé ${ }^{554}$. A antítese entre boa e má-fé revela a identidade de meios para suas descobertas, pois, verificada a existência de qualquer delas, a outra, necessariamente estará afastada, o que permite concluir que má-fé e boa-fé podem ser comprovadas por indícios, como inclusive reconhece Menezes Cordeiro ${ }^{555}$.

Esclarece Antonio Dellepiane que a prova indiciária não se produz por dedução, nem mesmo por indução. A dedução consiste no processo lógico pelo qual se parte de acontecimentos gerais para acontecimentos específicos, ao passo que a indução é o processo lógico inverso, que parte de um caso para uma generalidade ${ }^{556}$. Verifica-se que a prova dos indícios dá-se por inferência, isto é, da observância de algo que rotineiramente ocorre, mas nem sempre, pois não se cuida de uma reação natural ou geral, e que permite chegar a uma conclusão. Vejamos a doutrina:

\begin{abstract}
"Em verdade, na inferência indiciária, a lei que lhe serve de fundamento, que constitui a premissa maior do silogismo correspondente, não é sempre uma lei cientificamente comprovada e de um caráter necessário, senão que uma lei empírica, uma generalização fornecida pela experiência, um princípio de senso comum, cujo caráter é contingente. Que o autor de um crime foge ou se oculta depois de cometê-lo e, reciprocamente, que todo aquêle que foge e se oculta o faz porque cometeu um delito, são verdades gerais e constantes. Daí, entretanto, se deduz uma generalização: aquele que foge ou se oculta é um criminoso; e esta generalização serve de premissa para estabelecer que um determinado sujeito é autor de um delito.
\end{abstract}

\footnotetext{
${ }^{552}$ ROSENBERG, Leo. Tratado de derecho procesal civil. Tradução de Ângela Romera Vera. Tomo II. Libro segundo: el procedimento de sentencia. Buenos Aires: Ediciones Jurídicas Europa-America, 1955, p. 203.

${ }^{553}$ LEAL, Câmara. Cód. De Proc. Civ. e Com. Do Estado de São Paulo, 2. ․ v., p.139.

${ }_{554}^{55}$ SANTOS, Moacyr Amaral. Prova Judiciária no Cível e Comercial. Volume I. Max Limonad, p. 89.

${ }^{555}$ Vejamos os dizeres do doutrinador: "na verdade - é isto uma constatação irrefutável - o juiz só pode promanar, como qualquer pessoa, juízos em termos de normalidade. Fora a hipótese de haver um conhecimento directo da má fé do sujeito - máxime por confissão - os indícios existentes apenas permitem constatar que, nas condições por eles representadas, uma pessoa, com o perfil do agente, se encontra, numa ótica de generalidade, em situação de ciência ou ignorância. Mas sendo assim - e é assim - a concepção psicológica da boa fé torna-se, aquando da aplicação, numa aparência. $\mathrm{O}$ esquema real é outro: reunidos os indícios, o juiz constata que a pessoa em causa deve encontrar-se nas referidas situações de ciência ou de ignorância porque, das duas uma: ou se encontra, de fato, nelas ou, não se encontrando, devia encontrar-se, dado os fatores que a rodeiam. Ou sabe, ou deve saber, sendo certo que apenas o último termo é susceptível de apreciação e de controlo". In: CORDEIRO, António Manuel da Rocha e Menezes. Da boa fé no direito civil. Almedina, 2011, p. 515.

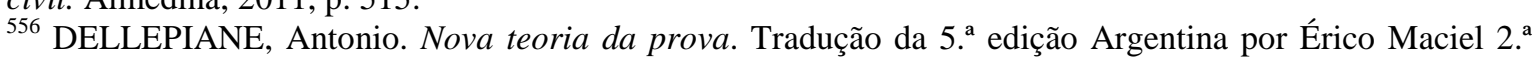
edição. José Konfino - Editor. Rio de Janeiro, 1958, p. 68.
} 
Não há aí uma dedução rigorosa, senão que o que os lógicos denominam, um raciocínio por analogia ou uma inferência analógica. Suponhamos que dois homens sejam viciados na ebridade, dotados de caráter identicamente violento, impulsivo, ou que êles tenham procedido de modo semelhante: fugindo, ocultando-se, alterando a verdade. Um dêsses homens foi o autor de um crime: inferimos que o outro é também autor de outro crime. Analisando o processo mental que intervém nestes casos, achamos que ele consiste em uma dedução apoiada em uma inferência indutiva prévia, tal qual como no caso do argumento comumente conhecido sob o nome de exemplo: "olha-te no espelho de Fulano, se persistes em jogar". O raciocínio implícito é este: os jogadores geralmente arruínam-se (inferência indutiva); tu, jogas do mesmo modo, logo te arruinarás, (inferência analógica)" ${ }^{, 557}$.

Os indícios são a base das presunções, aqueles levam, à conclusão, com êxito, a respeito de fato desconhecido produzindo essas ${ }^{558}$. Assim, pode-se conceituar a presunção como o convencimento antecipado de verdade provável a respeito de um fato desconhecido, obtida mediante fato conhecido e conexo ${ }^{559}$. Portanto, a presunção possui como elementos o convencimento antecipado, a verdade provável, o fato desconhecido e o fato conhecido e conexo.

Diz-se que se cuida de um convencimento antecipado, pois há uma conclusão a respeito de um fato antes de ele ter sido provado por meios diretos. Por outro lado, a presunção tem como elemento uma verdade provável, uma vez que se ampara na possibilidade de ocorrência de um evento, e não na sua efetiva ocorrência ${ }^{560}$. Ainda, o fato desconhecido é elemento indispensável para a presunção, tendo em vista que por meio da prova do fato conhecido será possível a comprovação do fato desconhecido ${ }^{561}$. Por fim, temos o fato conhecido e conexo, que se liga naturalmente ao desconhecido e permite formular conclusões a seu respeito ${ }^{562}$.

Impõem-se algumas considerações sobre as presunções, com maior razão diante da afirmação frequente de que a boa-fé se presume.

Registra Alípio Silveira que a natureza jurídica da presunção de boa-fé é estabelecida em razão da existência de disposições próprias no ordenamento jurídico, ocasião em que será compreendida como norma jurídica ou, silentes os diplomas

\footnotetext{
${ }^{557}$ DELLEPIANE, Antonio. Nova teoria da prova. Tradução da 5. ${ }^{a}$ edição Argentina por Érico Maciel 2. ${ }^{a}$ edição. José Konfino - Editor. Rio de Janeiro, 1958. pág. 69.

${ }_{558}$ COVELLO, Sérgio Carlos. A presunção em matéria civil. São Paulo: Saraiva, 1983, p. 116.

${ }^{559}$ Ibidem, p. 19.

${ }^{560}$ Ibidem, p. 20.

${ }^{561}$ Ibidem, p. 21.

${ }^{562}$ Ibidem, p. 24.
} 
normativos, terá feição de princípio geral do direito ${ }^{563}$. Em havendo normas jurídicas que tipifiquem hipóteses de presunção de boa-fé, sua incidência, como decorrência da lei, ficará restrita a elas, não obstando, contudo, a ocorrência de presunções por meio da atuação lógica do aplicador do direito.

Assim, nasce justamente da existência, ou não, de assento legal a distinção entre presunção legal e presunção comum. As presunções legais, bem como as comuns, são consequências extraídas de um fato conhecido em face do que ordinariamente acontece ou, ainda, parte de um fato conhecido que possui relação e capacidade de revelar um fato desconhecido $^{564}$, mas, nas presunções comuns, cabe ao juiz a realização do raciocínio que leva à presunção, ao passo que, nas legais, é a lei que estabelece a presunção ${ }^{565}$. Desse modo, apenas se poderá cogitar a ocorrência de presunção legal nas hipóteses em que há norma jurídica a estabelecendo. Por outro lado, inexistindo previsão normativa, estaremos diante da presunção comum, fruto da atuação do aplicador do Direito.

São encontradas especialmente no Direito Civil presunções legais a respeito da boa-fé, como ocorre, por exemplo, como os artigos $164^{566}$, 1201, parágrafo único ${ }^{567}$, e $1202^{568}$. Ainda, há diversas ocorrências em que o legislador presume a má-fé, como no art. $163^{569}$ e no art. 1256, parágrafo único ${ }^{570}$, o que acaba por indicar, com especial atenção ao ordenamento jurídico brasileiro, a não adoção da boa-fé como princípio geral, mas, somente, como norma de incidência estabelecida pelo legislador ordinário, que, em determinadas hipóteses acaba, até mesmo, presumindo a má-fé.

\footnotetext{
${ }^{563}$ SILVEIRA, Alípio. A Bôa Fé no Direito Civil. Typ. Paulista, 1941, p. 63.

564 LEITE, João Antonio G. Pereira. A presunção no direito do trabalho. Disponível em: <http://www.amatra4.org.br/cadernos/123-caderno-01?start=1>. Acesso em 30.06.2013.

${ }^{565}$ SANTOS, Moacyr Amaral. Prova Judiciária no Cível e Comercial. Volume I. Max Limonad, p. 377.

566 “Art. 164. Presumem-se, porém, de boa-fé e valem os negócios ordinários indispensáveis à manutenção de estabelecimento mercantil, rural, ou industrial, ou à subsistência do devedor e de sua família”.

567 “Art. 1.201. É de boa-fé a posse, se o possuidor ignora o vício, ou o obstáculo que impede a aquisição da coisa.

Parágrafo único. O possuidor com justo título tem por si a presunção de boa-fé, salvo prova em contrário, ou quando a lei expressamente não admite esta presunção”.

568 "Art. 1.202. A posse de boa-fé só perde este caráter no caso e desde o momento em que as circunstâncias façam presumir que o possuidor não ignora que possui indevidamente".

$569^{3}$ "Art. 163. Presumem-se fraudatórias dos direitos dos outros credores as garantias de dívidas que o devedor insolvente tiver dado a algum credor".

570 “Art. 1.256. Se de ambas as partes houve má-fé, adquirirá o proprietário as sementes, plantas e construções, devendo ressarcir o valor das acessões.

Parágrafo único. Presume-se má-fé no proprietário, quando o trabalho de construção, ou lavoura, se fez em
} sua presença e sem impugnação sua". 
O processo sofre forte influência das presunções, notadamente no campo das provas, haja vista o art. 334, IV, do CPC consagrar a desnecessidade de prova sobre os fatos em cujo favor milita presunção legal de existência ou de veracidade ${ }^{571}$. Ao se observar a legislação em apreço, logo se verifica que a desnecessidade de prova alcança, tão somente, as presunções legais, o que implica dizer que as presunções comuns ou simples dependem de provas, ainda que - e normalmente o são - indiciárias.

Depreende-se do citado dispositivo processual que a presunção legal dispensa do ônus da prova aquele que a tem a seu favor. Dessa forma, quem invoca a presunção legal não precisa provar o fato presumido pela lei, mas deverá provar os fatos nos quais a lei funda a presunção. Lado outro, o estabelecimento da presunção, em observância ao contraditório, não impede o oferecimento de prova contrária ao fato que ampara a presunção por aquele que a ela se opõ $e^{572}$. Logo, mesmo se cuidando de presunção legal, faz-se necessária a atuação probatória daquele por ela favorecido, o que permite afirmar que a existência de presunção não significa ausência de prova e, tampouco, desnecessidade de prova, muito menos obstáculo à prova de fato contrário.

Tendo em vista que se pretende no presente estudo a oferta de direitos ao trabalhador de boa-fé e, ainda, a inexistência de norma jurídica que a presuma, mostra-se indispensável a comprovação da boa-fé. Trata-se de presunção comum, também chamada de simples, judicial ou humana (hominis), que é aquela estabelecida exclusivamente pelo raciocínio do juiz e, mais uma vez se repete, não se confunde com a presunção estabelecida em $l \mathrm{ei}^{573}$.

Desta feita, primando pela clareza das ideias, afirmamos que a boa-fé passível de acudir o trabalhador no caso de relação de emprego nula não é afirmada em nenhuma norma jurídica, o que exige sua demonstração em juízo.

Como dito, a presunção é uma conclusão a respeito de um fato desconhecido construída a partir de fatos conhecidos. Não se cuida de atividade de adivinhação, mas de conclusão amparada em fatos conexos, os indícios, que, uma vez provados, darão ensejo à presunção.

\footnotetext{
571 “Art. 334. Não dependem de prova os fatos: (...) IV - em cujo favor milita presunção legal de existência ou de veracidade".

${ }^{572}$ SANTOS, Moacyr Amaral. Prova Judiciária no Cível e Comercial. Volume I. Max Limonad, p. 383.

${ }^{573}$ MARINONI, Luiz Guilherme; ARENHART, Sérgio Cruz. Prova. 2.ed. ver. e atual. São Paulo: Editora Revista dos Tribunais, 2011, p. 138.
} 
O indício é o fato conhecido que guarda relação com o fato desconhecido e que pode produzir a presunção. Na prova por indício três elementos se relacionam, a saber: o fato conhecido, o fato desconhecido e a relação de causalidade, concomitância ou conexão entre um e outro ${ }^{574}$. Desse modo, há uma ligação entre o fato conhecido e o fato desconhecido, ainda que não seja necessária, e dessa ligação pode resultar a presunção.

Considerando que os limites do litígio, causa de pedir e pedido ${ }^{575}$, são fixados pelas partes na chamada fase postulatória, petição inicial ${ }^{576} 577$ para o autor ou reclamante e resposta do réu ou reclamado ${ }^{578} 579$, é possível que a necessidade da prova indiciária seja percebida ou revelada em momento posterior ao da estabilização da lide, o que pode gerar discussões acerca da violação aos princípios do contraditório e da ampla defesa. Todavia, as garantias fundamentais não sofrem nenhuma lesão, pois o indício, como fato secundário, deve possuir estreita ligação com as alegações fáticas realizadas pelas partes nos momentos apropriados e, dessa forma, já submetidas ao contraditório ${ }^{580}$ e, ainda, é da essência da distinção entre prova direta e indireta que essa última recaia sobre argumentos verificáveis, que possibilitem chegar, por ilação, à prova do fato principal, ao passo que aquela recai sobre o próprio objeto da afirmação ${ }^{581}$.

\footnotetext{
${ }^{574}$ GARCIA S., Alfonso. Los indicios. Estudios de Derecho. Medellin. v.49. n.113/114. p.203-15. mar./sept. 1989, p. 204.

575 "CPC, Art. 128. O juiz decidirá a lide nos limites em que foi proposta, sendo-lhe defeso conhecer de questões, não suscitadas, a cujo respeito a lei exige a iniciativa da parte".

576 "CPC, Art. 282. A petição inicial indicará: III - o fato e os fundamentos jurídicos do pedido; IV - o pedido, com as suas especificações".

577 "CLT, Art. 840 - A reclamação poderá ser escrita ou verbal.

$\S 1^{\circ}$ - Sendo escrita, a reclamação deverá conter a designação do Presidente da Junta, ou do juiz de direito a quem for dirigida, a qualificação do reclamante e do reclamado, uma breve exposição dos fatos de que resulte o dissídio, o pedido, a data e a assinatura do reclamante ou de seu representante".

578 "CPC, Art. 297. O réu poderá oferecer, no prazo de 15 (quinze) dias, em petição escrita, dirigida ao juiz da causa, contestação, exceção e reconvenção".

579 "CLT, Art. 847 - Não havendo acordo, o reclamado terá vinte minutos para aduzir sua defesa, após a leitura da reclamação, quando esta não for dispensada por ambas as partes".

${ }^{580}$ Segundo Luigi Lombardo "La prova indiretta, vertendo su um fatto secondario, viene a introdurre, dunque, un nuovo tema di prova (5), un tema di prova "secondario", distinto dal thema probandum (o tema "principale"). Questo tema di prova, in quanto "secondario", non è um tema che deve essere provato a pena di soccombenza, come il tema principale; è un tema che può essere provato e che la parte ha interesse a provare quando non disponde di prove dirette". In La prova giudiziale: contributo alla teoria del giudizio di fatto nel processo. Università di Catania. Publicazioni della Facoltà di Giurisprudenza. Giuffrè editore, 1999, pp. 318-319.

${ }^{581}$ Nesse sentido Franceso Carnelutti: "Gli uomini e le cose, che fungono da prove, possono servire a tale ufficio in due mode: o perchè sono l'oggeto stesso dell'affermazione da verificare o perchè forniscono um argomento allá verificazione. Questa è la distinzione, già fatta, tra lê prove dirette e le prove indirette". In: CARNELLUTI, Francesco. Sistema di diritto processuale civile. I - funzione e composizione del processo. Padova: Cedam, 1936, p. 681.
} 
São exemplos de fatos acessórios qualificados como indícios que possibilitam à constatação da boa-fé do trabalhador como fato principal: o grau de escolaridade, suas experiências profissionais anteriores, locais de residência, além de outros que podem ser definidos pelas próprias partes ou pelo juiz ${ }^{582}$. Além desses, Gustavo Alexandre Magalhães e Jorge Luiz Souto Maior destacam as seguintes circunstâncias, que, por sua vez, servirão de indício contrário à alegação de boa-fé: relação de parentesco entre o servidor e a autoridade de alto escalão da Administração, notória relação de afinidade pessoal, remuneração elevada, contratação de servidor em área estratégica da Administração (jurídico, financeiro e contábil), elevado nível de instrução do servidor de fato, existência de relação de confiança entre o trabalhador e a autoridade administrativa, baixo número de pessoas de fato que exercem a função ${ }^{583}$.

Em síntese, a boa-fé subjetiva do trabalhador será caracterizada ou rejeitada por presunção, de modo que os indícios que permitem a formação da convicção judicial acerca da ignorância sobre o vício que macula a validade do negócio jurídico constituem o objeto de prova.

\section{Meios de prova.}

Meios de prova são as coisas corpóreas que podem fornecer ao juiz a percepção sobre o objeto de prova. Podem ser vistos, ainda, como aquilo que facilita ou comunica o juiz sobre os fatos ${ }^{584}$.

Em determinado momento da história da humanidade, a solução de controvérsias não era feita pelo homem, mas pela Divindade, a quem se atribuía o dever de garantir a paz

\footnotetext{
${ }^{582}$ Muito embora o objeto da prova repouse sobre os indícios, o aplicador do direito não pode perder de vista a pouca proximidade do povo brasileiro com suas constituições, nem mesmo o histórico constitucional que revela a livre ocupação da generalidade dos cargos e empregos públicos sem qualquer aprovação em concurso público. Partindo-se da idéia de que o início da história constitucional de um Estado principia com o surgimento de sua própria Lei maior, pode-se afirmar que a caminhada teve início em 1824. Ao longo dos 188 anos de constitucionalismo brasileiro, somente com a Constituição de 1988, há apenas 24 anos, teve início a exigência ampla de concurso público, o que sugere o baixo conhecimento da população brasileira a respeito desse procedimento e, principalmente, de sua obrigatoriedade.

${ }_{583}$ MAGALHÃES, Gustavo Alexandre; SOUTO MAIOR, Jorge Luiz. Efeitos da nulidade na contratação de servidores públicos. in O Servidor público e a Justiça do Trabalho: homenagem ao Ministro Ronaldo José Lopes Leal. José Ronald Cavalcante Soares, coordenador. São Paulo: LTr, 2005, 132.

${ }_{584}$ ROSENBERG, Leo. Tratado de derecho procesal civil. Tradução de Ângela Romera Vera. Tomo II. Libro segundo: el procedimento de sentencia. Buenos Aires: Ediciones Jurídicas Europa-America, 1955, p. 203.
} 
social. Nesse período, o processo não passava de um ritual religioso dominado por formas oriundas de normas consuetudinárias de natureza místico-religiosa, que retiravam do julgador a responsabilidade pelo julgamento e o guiavam na descoberta da verdade divina. Essa ritualística tinha a peculiaridade de não admitir contraprova, pois configurava blasfêmia tentar desmentir a verdade divina. Os meios de prova utilizados eram os oráculos que consultavam a Divindade e os ordálios, que eram provações às quais os acusados eram submetidos para provarem sua inocência ou culpa ${ }^{585}$.

A primeira aparição do conceito de prova, em um dos sentidos modernos do termo, está ligada à dessacralização do processo romano. Em tal período, o processo é visto como manifestação da autonomia privada, de modo que a figura em destaque não passava de uma forma de autotutela consensual e forçosa, arbitrada e imposta pelo Estado $^{586}$.

Com o avançar da história, a concepção retórica da prova cede espaço à concepção científica (ou técnica), que busca a verdade material, absoluta, objetiva e impessoal, pretendendo-se a adoção, no campo jurídico, dos mesmos procedimentos de pesquisa que eram experimentados nas ciências exatas. Essa concepção tinha a peculiaridade de apenas enxergar limitações à produção de provas quando os meios ou as provas fossem irracionais ou inaceitáveis e, também, de conferir amplíssimos poderes de ofício ao juiz, o que poderia acarretar, ao menos para alguns, assimetria processual ${ }^{587}$.

No modelo de processo liberal, abandona-se o sistema científico ou de certezas, que justificava o sistema da prova legal, e adota-se o sistema de livre convencimento do juiz $^{588}$. Esse modelo manifestou-se no código napoleônico e no "codice de procedura civile dell'Italia”, que eram expressões da consciência burguesa, classe que nutria convicção absoluta no livre mercado e que via no papel intervencionista do Estado um perigo à liberdade individual, o que sugeria o processo como um local em que prevalecesse a plena autonomia dos indivíduos ou das partes ${ }^{589}$.

\footnotetext{
585 LOMBARDO, Luigi. La prova giudiziale: contributo alla teoria del giudizio di fatto nel processo. Università di Catania. Publicazioni della Facoltà di Giurisprudenza. Giuffrè editore, 1999, pp 2 e 3.

${ }^{586}$ Ibidem, p.5.

${ }^{587}$ Ibidem, pp. 16 e 17.

${ }^{588}$ Ibidem, p. 21.

${ }^{589}$ Luigi Lombardo destaca “questo "modelo liberale"di processo civile - culminato nel codice napoleônico e poi trasfuso nel primo codice di procedura civile dell'Italia unita, promulgato nel 1865 - era espressione della concezione borghese e proto-liberale di rapporti giuridici, che si andava affermando; una concezione che nutriva una fede cieca nel libero mercato, che vedeva nel ruolo interventisto dello Stato um insidioso pericolo
} 
Contemporaneamente, ganha força a concepção publicista do processo, que consagra a ampliação dos poderes do juiz, enquanto órgão que concretiza a função jurisdicional do Estado ${ }^{590}$. A postura ativa do magistrado em nada conflita com as garantias fundamentais, pois ao se defender a instrumentalidade do processo não se está advogando o arbítrio, pretendendo-se, sim, a atuação do Estado-juiz atenta à necessidade de prevalência da verdade e zelosa com o contraditório e com a igualdade das partes.

Os direitos e garantias fundamentais que repousam na vigente Constituição, em especial o acesso à justiça ${ }^{591}$, o contraditório e a ampla defesa ${ }^{592}$, asseguram aos litigantes vasta possibilidade de produção de provas, observadas apenas algumas restrições estabelecidas pelo mesmo diploma ${ }^{593} 594$. Não bastassem os mandamentos constitucionais, que, em razão de sua força normativa, vinculam a atuação dos cidadãos e dos ocupantes de Poderes (que também são cidadãos), encontramos previsão expressa no $\mathrm{CPC}$, senão vejamos a redação da regra em destaque:

"Art. 332. Todos os meios legais, bem como os moralmente legítimos, ainda que não especificados neste Código, são hábeis para provar a verdade dos fatos, em que se funda a ação ou a defesa".

Interessa observar que a CLT nada dispõe a respeito da vasta possibilidade de produção de provas ou a respeito de quais provas sejam admissíveis, o que em nada empobrece o Processo do Trabalho, em virtude da possibilidade de utilização subsidiária das regras do processo comum, autorizada pelo art. 769 do referido diploma, de seguinte conteúdo:

\footnotetext{
“Art. 769 - Nos casos omissos, o direito processual comum será fonte subsidiária do direito processual do trabalho, exceto naquilo em que for incompatível com as normas deste Título".
}

per lelibertá individuali, e che, facendo appello al princípio del laissez faire, conceptiva il processo come um terreno nel quale doveva avere attuazione il dogma della piena autonomia degli individui ("il processo è cosa delle parti”)". In: LOMBARDO, Luigi. La prova giudiziale: contributo alla teoria del giudizio di fatto nel processo. Università di Catania. Publicazioni della Facoltà di Giurisprudenza. Giuffrè editore, 1999. pp. 26 e 27.

${ }^{590}$ Ibidem, p. 29.

591 "XXXV - a lei não excluirá da apreciação do Poder Judiciário lesão ou ameaça a direito".

592 "LV - aos litigantes, em processo judicial ou administrativo, e aos acusados em geral são assegurados o contraditório e ampla defesa, com os meios e recursos a ela inerentes".

593 "XII - é inviolável o sigilo da correspondência e das comunicações telegráficas, de dados e das comunicações telefônicas, salvo, no último caso, por ordem judicial, nas hipóteses e na forma que a lei estabelecer para fins de investigação criminal ou instrução processual penal".

594 "LVI - são inadmissíveis, no processo, as provas obtidas por meios ilícitos". 
Logo, existindo omissão da CLT e compatibilidade das regras do processo comum com o trabalhista, torna-se possível a utilização das disposições do CPC.

Diante do teor dos parágrafos precedentes, qualquer meio de prova pode ser utilizado para revelar em juízo indícios da boa-fé do trabalhador. A expressa previsão de meios de prova pela legislação dá ensejo à classificação dos meios de prova em típicos e atípicos, reservada a última adjetivação àqueles meios de prova que, embora não proibidos, não encontram previsão em normas jurídicas.

Os principais meios de prova típicos são a exibição de documento ou coisa (arts. 355 a 363 do CPC), os documentos (arts. 364 a 399 do CPC), a prova testemunhal (arts. 400 a 419 do CPC), a prova pericial (arts. 420 a 439 do CPC) e a inspeção judicial (arts. 440 a 443 do CPC). Insta esclarecer que o depoimento pessoal (arts. 342 a 354 do CPC) não é meio de prova, pois, alcançada sua finalidade, a confissão, os fatos deixam de ser controvertidos e, desse modo, dispensa-se a atuação instrutória ${ }^{595}$.

No outro bordo, encontramos como recorrentes meios atípicos a prova emprestada, as declarações de terceiros e os laudos ou perícias arbitrais ${ }^{596}$, bem como cartas psicografadas ${ }^{597}$ para subsidiar as decisões do Estado-juiz.

Assim, ao menos em tese, o ordenamento jurídico pátrio admite a prova dos indícios da boa-fé subjetiva do trabalhador por qualquer meio. Contudo, não se pode esquecer que a boa-fé, em sua manifestação fática e subjetiva, é um estado de ignorância, o que afasta no atual estado da ciência a utilização de provas técnicas ${ }^{598}$, muito embora não sejam proibidas prima facie.

\footnotetext{
${ }^{595}$ ROSENBERG, Leo. Tratado de derecho procesal civil. Tradução de Ângela Romera Vera. Tomo II. Libro segundo: el procedimento de sentencia. Buenos Aires: Ediciones Jurídicas Europa-America, 1955, p. 204.

${ }^{596}$ LOPES, João Batista. Provas atípicas e efetividade do processo. Disponível em: $<$ http://www.arcos.org.br/periodicos/revista-eletronica-de-direito-processual/volume-v/provas-atipicas-eefetividade-do-processo>. Acesso em 29.05.2012.

${ }^{597}$ GERCHMANN, Léo. Carta psicografada ajuda a inocentar ré por homicídio no RS. Disponível em: <http://www1.folha.uol.com.br/folha/cotidiano/ult95u122179.shtml>. Acesso em 29.05.2012.

${ }^{598}$ Há um estudo nos EUA que afirma a possibilidade de descoberta das palavras pensadas pelas pessoas através da análise de suas ondas celebrais, o que permitiria, de certa maneira, relevar a intenção ou conhecimento fático das partes em algumas situações altamente subjetivas vide BBC BRAZIL. Cientistas desenvolvem técnica para "ler" pensamentos. Disponível em: <http://www1.folha.uol.com.br/bbc/1042322cientistas-desenvolvem-tecnica-para-ler-pensamentos.shtml>. Acesso em 29.05.2012.
} 
Desse modo, todos os meios de prova podem ser utilizados na comprovação da boa-fé, mas nem todos possuem a mesma eficácia para a prova do fato em relevo. Consoante o entendimento de Francesco Ferrara:

\begin{abstract}
“... se é verdade que os contratantes podem dispor de todos esses meios, não o é menos que nem todos eles têm a mesma eficácia para demonstrar a simulação, e que a exclusão, em regra da prova testemunhal ou por presunções, é que a melhor se adapta ao descobrimento do mistério que envolve o contrato, coloca os contratantes numa posição difícil e perigosa, pelo que sentem eles a necessidade, para sua segurança, de preconstituir uma prova documental da simulação"
\end{abstract}

Não se deve olvidar que as limitações destacadas pelo professor italiano a respeito da prova são feitas com os olhos direcionados às normas jurídicas vigentes em 1939, época da edição consultada. No caso brasileiro, há disposições no Código Civil a respeito da prova do negócio jurídico, cuidam-se dos arts. 212 a 232. A boa-fé encontra grande importância no Direito Civil e múltiplas incidências nas relações jurídicas próprias dessa seara, contudo, de maneira alguma há exclusividade, nem mesmo pretensão nesse sentido, de se vincular a boa-fé com o ramo do Direito em relevo. A boa-fé decorre do subprincípio constitucional da segurança jurídica ${ }^{600} \mathrm{e}$, devido à sua posição proeminente, influencia toda a ordem jurídica e seus aplicadores.

Nessa linha, o delineamento da prova do negócio jurídico dado pelo Código Civil e, consequentemente, da prova da boa-fé não se aplicaria aos litígios com amparo em normas diversas daquelas que se ocupam a espécie de ato jurídico mencionada acima. Portanto, em litígios diversos do propriamente cível, o que inclui o contrato de emprego nulo, a diretriz para a prova seria aquela prevista no CPC, ou seja, a admissibilidade ampla dos meios de prova.

Outro dado mencionado pelo professor italiano diz respeito à eficácia dos meios de prova. É certo que os meios de prova produzem, em termos de revelação da verdade, resultados distintos. Um vídeo da parte ou um escrito de sua autoria (provas documentais), que contenham declaração de ciência de que sua empregadora integra a Administração Pública, ou dizeres da testemunha que revelem a sabedoria do reclamante, podem provar de maneira cabal a ausência de boa-fé. Porém, a grande dificuldade de produção de provas

\footnotetext{
${ }^{599}$ FERRARA, Francesco. A Simulação dos negócios jurídicos. Trad. Do Dr. A. Bossa. Saraiva \& Cia., 1939, p. 413 .

${ }^{600}$ O Estado Democrático de Direito possui assento constitucional e natureza jurídica de princípio. Em razão de sua natureza jurídica que o faz irradiar efeitos em toda ordem jurídica e servir de fonte para outros princípios que recebem o nome de subprincípios, entre os quais encontramos o da segurança jurídica.
} 
históricas acarreta a necessidade de utilização de meios de prova hábeis a revelar a verdade a respeito dos indícios.

Grau de escolaridade, experiências anteriores e locais de residência são provados com maior eficiência por meio de documentos, por exemplo, o histórico escolar, a Carteira de Trabalho e Previdência Social e contas de consumo de serviços públicos, respectivamente. Contudo, frisa-se, mais uma vez, que a maior eficiência não impossibilita a utilização de meios de prova distintos, pois se adota no sistema pátrio a ampla admissibilidade, como dito.

Portanto, todos os meios de prova podem ser utilizados para prova da boa-fé subjetiva do trabalhador ou dos indícios que permitam caracterizá-la, muito embora a casuística possa indicar a maior eficiência de alguns meios de prova em comparação com outros.

\section{A quem incumbe a prova da boa-fé?}

O processo pode ser visto, também, como um dos métodos civilizados de solução de conflitos, por meio do qual o Estado-juiz busca fazer valer as proposições normativas que mereçam incidência de acordo com o arcabouço fático que se apresente. Para tanto, o dever de dizer o direito seria e é facilitado na medida em que as partes trazem para o processo apenas alegações fáticas que encontram repercussão na realidade. Há, inclusive, previsão expressa na doutrina estrangeira que impõe às partes o dever de narrar os fatos como os perceberam, sem alterações ardilosas ${ }^{601}$.

Pode soar como ingenuidade acreditar que os sujeitos parciais do processo compareçam e atuem, em geral, imbuídos do desejo de ver prevalecer a correta aplicação das normas jurídicas de direito material, pretendendo, isto sim, com algumas exceções, ver prevalecer suas alegações fáticas, sair vencedor, mesmo que sua tese não encontre nenhuma correspondência com a verdade. Para as hipóteses em que os litigantes alteram a verdade dos fatos para fazer prevalecer suas teses, o CPC prevê a figura da litigância de

\footnotetext{
${ }^{601}$ Friedrich Lent ao estudar o ônus da prova no direito tedesco afirma "questa distinzione há però perso di valore, dopo che alle parti è stato attribuito il dovere di veridicità (§ 138), in virtù del quale ciascun litigante è tenuto a narrarei 1 fatto nel suo complesso, cosi come a lui noto, senza esclusione de punti sfavorevoli." In: LENT, Friedrich. Diritto Processsuale Civile Tedesco, parte prima: il procedimento di cognizione. Traduzione di Edoardo F. Ricci. Morano Editore, 1962, p. 203.
} 
má-fé, que implica a imposição, ao ofensor do dever jurídico de lealdade, da obrigação de pagar multa em valor não superior a um por cento do valor dado à causa e indenização em valor não excedente a vinte por cento da mesma base.

Ocorre que, em diversas oportunidades, mesmo diante da atuação instrutória das partes e, até mesmo, do juiz, não se alcança convencimento seguro a respeito de alegações realizadas no processo, o que aduz a premência de se decidir quem deve provar determinada alegação sobre um fato ou, se se preferir, determinar sobre quem incide o ônus da prova.

Há, contudo, acirrada disputa doutrinária e jurisprudencial acerca da natureza jurídica do ônus da prova, isto é, se constitui diretriz para a produção da prova ou regra de julgamento. O fundamento normativo da celeuma repousa no art. 818 da CLT e no art. 333 do CPC, vejamos os teores:

"Art. 818 - A prova das alegações incumbe à parte que as fizer."

“Art. 333. O ônus da prova incumbe:

I - ao autor, quanto ao fato constitutivo do seu direito;

II - ao réu, quanto à existência de fato impeditivo, modificativo ou extintivo do direito do autor.

Parágrafo único. É nula a convenção que distribui de maneira diversa o ônus da prova quando:

I - recair sobre direito indisponível da parte;

II - tornar excessivamente difícil a uma parte o exercício do direito”.

A resposta varia de acordo com o entendimento que se tenha a respeito do processo e da postura do juiz dentro do processo. Possui grande aceitação a concepção de que o direito processual, apesar de autônomo, possui natureza instrumental em relação ao direito material. A instrumentalidade é facilmente percebida nos fins do processo. Cândido Rangel Dinamarco destaca três escopos, o social, o político e o jurídico; os primeiros representam a pacificação com justiça e a educação da sociedade por meio da conscientização de seus membros para direitos e obrigações ${ }^{602}$; os segundos consagram a capacidade estatal de decidir imperativamente, a concretização do valor liberdade e o ato

602 DINAMARCO, Cândido Rangel. A instrumentalidade do processo. 14. ${ }^{\text {a }}$ ed. revista e atualizada. São Paulo: Malheiros, 2009, pp. 188 e 191. 
de assegurar a participação dos cidadãos, por eles mesmos, nos destinos da sociedade política $^{603}$; por derradeiro, o escopo jurídico representa a atuação da vontade concreta da $1 i^{604}$.

O presente trabalho segue uma diretriz instrumentalista, de modo que o juiz deve atuar na busca da verdade, cabendo aos sujeitos processuais parciais e ao Estado-juiz atuação conjunta, pois é do interesse de toda a sociedade a observância das normas jurídicas ${ }^{605} 606$. Nessa diretriz, o ônus da prova só ganhará relevo nas hipóteses em que as alegações fáticas realizadas pelas partes não forem comprovadas, isto é, se todo o esforço envidado na descoberta da verdade não for bem sucedido, momento a partir do qual a solução da lide dependerá da utilização do ônus da prova, não como regra de organização da atuação das partes em audiência, mas como regra de julgamento, muito embora exista valiosa doutrina defendendo entendimento distinto ${ }^{607}$.

Mas não se pode perder de vista que o processo tem início com o exercício do direito da ação e encontra seu final com o trânsito em julgado da decisão final. A sentença, atendidas as condições e os pressupostos necessários à análise do mérito do processo, e ocorrendo a preclusão quanto aos meios de manifestação de contrariedade, produz o efeito da coisa julgada.

Ora, não é dado ao Estado-juiz deixar de decidir determinado conflito ou crise de direito material em razão da ausência de prova. Desta feita, inevitavelmente, o ônus da prova representa regra de julgamento, tornando-se indispensável a identificação daquele

${ }^{603}$ DINAMARCO, Cândido Rangel. A instrumentalidade do processo. 14. ${ }^{\mathrm{a}}$ ed. revista e atualizada. São Paulo: Malheiros, 2009, p. 198.

${ }^{604}$ Ibidem, p. 246.

605 “Tal onere non há alcuna importanza per quanto concerne la proposizione delle istanze istruttorie, qualora esse provengano da entrambe le parti. Il giudice há infatti in questo caso il dovere di assumere tutte lê prove che gli sembrano rilevanti, senza precuparsi di sapere a chi competa il relativo onere. (Anche in pratica accade di frequente che i litiganti formulino le loro richiste senza prendere in considerazione questo punto)". In: LENT, Friedrich. Diritto Processsuale Civile Tedesco, parte prima: il procedimento di cognizione. Traduzione di Edoardo F. Ricci. Morano Editore, 1962, p. 203.

${ }^{606}$ BEDAQUE, José Roberto dos Santos. Poderes instrutórios do juiz. 5.ed. ver., atual. e ampl. São Paulo: Editora Revista dos Tribunais, 2011, p. 127.

${ }^{607}$ Ao que parece Leo Rosenberg entende o ônus da prova como regra que conduz a atuação das partes em instrução ao afirmar que "La aplicación del derecho, es decir, la conclusión que debe afirmar producidos los efectos de los preceptos jurídicos por aplicar, depende del estabelecimento de la existência de aquellas circunstancias de hecho a las que el ordenamiento jurídico há unido la producción de tales efectos. En tanto que estas circunstancias de hecho no puedan considerarse como establecidas o están establecidas por otras causas (véase infra, §113) deben ser probadas por las partes dentro de la esfera del princípio de disposición (véase supra, § 63, II); y serán averiguadas por el juez". In: ROSENBERG, Leo. Tratado de derecho procesal civil. Tradução de Ângela Romera Vera. Tomo II. Libro segundo: el procedimento de sentencia. Buenos Aires: Ediciones Jurídicas Europa-America, 1955, p. 200. 
que possui o ônus de provar a boa-fé ou sua ausência. Não é outro o entendimento defendido por José Roberto dos Santos Bedaque:

“As regras referentes à distribuição do ônus da prova devem ser levadas
em conta pelo juiz apenas e tão somente no momento de decidir. São
regras de julgamento, ou seja, destinam-se a fornecer ao julgador meios
de proferir a decisão, quando os fatos não restaram suficientemente
provados. Antes disso, não tem ele de se preocupar com as normas de
distribuição do ônus da prova, podendo e devendo esgotar os meios
possíveis, a fim de proferir julgamento que retrate a realidade fática e
represente a atuação da norma à situação apresentada em juízo. Os
princípios estabelecidos no art. 333 do CPC só devem ser aplicados
depois que tudo for feito no sentido de se obter a prova dos fatos. E
quando isso ocorre, não importa sua origem, isto é, quem a trouxe para os
autos" 608 .

Faz-se antes necessário esclarecer alguns pontos próprios da prova da boa-fé subjetiva.

Impera observar que a ausência de pressuposto de validade representa a formação do negócio jurídico em desconformidade com a lei, de maneira que a nulidade é uma penalidade imposta pela lei e que pode, como em regra ocorre, interferir na produção de efeitos jurídicos. Em idêntica direção, a produção de efeitos jurídicos em razão da boa-fé surge como medida excepcional que possibilitará que o ato se manifeste com maior expressão.

Com efeito, nos casos em que há a discussão da boa-fé subjetiva, é necessário identificar o pressuposto faltante para, a partir dele, questionar-se a existência do instituto em destaque. Logo, não comprovada a ausência do pressuposto de validade, são desnecessários questionamentos ou conclusões a respeito da boa-fé. Por outro lado, reconhecida no processo a falta de pressuposto de validade, será indispensável o direcionamento da atividade instrutória para a prova da ignorância, que, como já dito, fazse por indícios.

Não provados os indícios e, dessa maneira, impossibilitada a formação de convencimento a respeito da boa-fé subjetiva do trabalhador, o julgamento deve ser feito em desfavor do sujeito que alega ser desconhecedor da situação fática irregular. Essa

\footnotetext{
${ }^{608}$ BEDAQUE, José Roberto dos Santos. Poderes instrutórios do juiz. 5.ed. ver., atual. e ampl. São Paulo:
} Editora Revista dos Tribunais, 2011, p. 128. 
conclusão tem como principal fundamento a regra segundo a qual incumbe a quem alega o ônus de provar (art. 818 da CLT e art. 333 do CPC).

Há doutrinadores que defendem que, prestados serviços ao Estado em caráter subordinado, o trabalhador estará de boa-fé e caberá à Administração a prova da má-fé do obreiro $^{609}$. Contudo, não concordamos com esse entendimento, vejamos as razões.

A nulidade em exame representa consequência jurídica para prática de ato em detrimento de pressuposto de validade de extrema relevância para a proteção do interesse público, consubstanciado em norma situada no ápice da pirâmide normativa pátria, cenário em que a ampla produção de efeitos jurídicos é exceção, que apenas se estabelece com a presença da boa-fé subjetiva, de modo que sua prova interessa, em especial, ao trabalhador, de maneira que a ausência de provas acarreta o julgamento em seu desfavor.

Em complemento, cumpre recordar a ausência de norma jurídica que presuma a boa-fé de empregados que prestem trabalhos à Administração Pública à míngua de concurso público, peculiaridade que afasta a dispensa de prova contida no art. 334, IV, do CPC. Sob essa ótica, justificar-se-ia, somente, a tese de que cabe à Administração Pública a prova da má-fé do trabalhador diante da existência de presunção de boa-fé, o que não ocorre na hipótese e resulta a inserção da alegação de ignorância na diretriz geral segundo a qual quem alega deve provar.

Cumpre esclarecer, atento à diretriz mencionada ao final do parágrafo precedente, que a alegação de boa-fé (subjetiva), no contexto do presente trabalho, possui a natureza jurídica de fato constitutivo ${ }^{610}$, especificamente do direito à exclusão de ineficácia do negócio jurídico nulo. O afastamento da ineficácia depende da prova da boa-fé e é justamente nesse sentido que se afirma que a ignorância, como manifestação da boa-fé subjetiva, é fato constitutivo do direito à incidência da excludente em referência. Frise-se que, em razão da natureza punitiva da nulidade, a consequência ordinária para a não

\footnotetext{
${ }^{609}$ MAGALHÃES, Gustavo Alexandre; SOUTO MAIOR, Jorge Luiz. Efeitos da nulidade na contratação de servidores públicos. in O Servidor público e a Justiça do Trabalho: homenagem ao Ministro Ronaldo José Lopes Leal. José Ronald Cavalcante Soares, coordenador. São Paulo: LTr, 2005, 125.

${ }^{610}$ Luiz Guilherme Marinone e Sérgio Cruz Arenhart recordam a exitência de outras espécies de fatos que repercutem no ônus da prova, ao afirmar que "vale lembrar o seguinte: se o autor pede o pagamento da dívida e o réu alega que ela foi parcelada, somente podendo ser exigida em parte, o fato é modificativo; se o réu alega o pagamento, o fato é extintivo; se o réu afirma a exceção de contrato não cumprido, o fato é impeditivo". In: MARINONI, Luiz Guilherme; ARENHART, Sérgio Cruz. Prova. 2. Ed. ver. e atual. São Paulo: Editora Revista dos Tibunais, 2011, p. 181.
} 
observância dos pressupostos de validade é ineficácia, muito embora, como já esclarecido, cuidem-se a validade e a ineficácia de planos distintos do ato ou do negócio jurídico.

Veja-se que, desse modo, a boa-fé revela sua função de proporcionadora de direitos ou de excludente de ineficácia, no que se assemelha com a excludente de tipicidade denominada erro de tipo ${ }^{611}$, própria do Direito Penal. Isso em razão de as figuras mencionadas possuírem a característica de afastar a penalidade imposta pelo ordenamento jurídico, no caso penal, a aplicação de multas, penas restritivas de direitos e privativas de liberdade, ao passo que para o Direito Comum, ou não penal, o resultado da não observância dos pressupostos de validade, ou de alguns deles, em geral, afeta a eficácia do negócio ou ato jurídico, de maneira que a prova da exceção ou da excludente interessa especialmente àquele que a alega.

Assim, afirma-se que a solução do processo com a utilização do ônus da prova como regra de julgamento deve ser feita em desfavor daquele que afirma ignorar o vício que macula a formação do negócio jurídico, visto que é o autor da alegação de boa-fé, o beneficiado pela ampla produção de efeitos ou concessão de direitos decorrentes da incidência da função excludente de ineficácia e, por fim, inexiste norma jurídica que presume a boa-fé para o caso.

611 "Código Penal. Art. 20 - O erro sobre elemento constitutivo do tipo legal de crime exclui o dolo, mas permite a punição por crime culposo, se previsto em lei”. 


\section{CONCLUSÃO.}

A ampla exigência de concurso público para a ocupação de cargos e empregos públicos nem sempre esteve presente, o que, sem sombra de dúvidas, tornava frágil qualquer pretensão de igualdade entre os cidadãos, ainda mais em sociedades como a contemporânea à Constituição de 1824, que possuía ideais e estruturas um tanto quanto contraditórias e, talvez, inconciliáveis.

Apenas com a Constituição de 1988 estabeleceu-se de maneira ampla a igualdade de acesso à Administração e, para tanto, se consagrou a exigência do concurso público, que pode ser compreendido, como o procedimento por meio do qual se verifica a aptidão e os conhecimentos dos pretendentes aos postos públicos. Nessa ótica, o concurso público mostra-se como meio de acesso democrático, que realiza os princípios constitucionais consagrados no art. 37 da Lei maior.

Veja-se que no decorrer de nossa curta história constitucional, com pouco mais de 180 anos, apenas com a última Constituição a prévia passagem por concurso público tornou-se uma determinação geral, o que indica ou auxilia a explicar o pouco conhecimento da esmagadora maioria da população brasileira sobre nossa Constituição e sobre os procedimentos por ela exigidos.

Esse distanciamento entre a população brasileira e sua Constituição parece não ser levado em consideração pelo TST nos processos em que pessoas não concursadas, que efetivamente prestaram serviços para a Administração, pretendem a concessão de direitos. Isso porque seus julgamentos não distinguem aqueles que ignoram a exigência do procedimento por desconhecerem que prestam trabalhos à Administração Pública, e assim estão de boa-fé, dos que conscientemente se aproveitaram das facilidades decorrentes da ausência de organização da Administração ou da altivez de administradores públicos que confundem o interesse público com o interesse particular.

Contudo, recentes decisões do Corte trabalhista sinalizam o abrandamento dos rigores adotados anteriormente no que se refere à ausência de concurso público, mediante o elastecimento das hipóteses de concessão de direitos, muito embora os julgados ainda não mencionem a ora defendida distinção entre trabalhadores de boa e de má-fé. 
A escolha da boa-fé como ponto de proximidade entre os princípios da Administração Pública diretamente relacionados com o concurso público e o valor social do trabalho, princípio superior no qual se assenta o fundamento para a observância ou incidência das normas trabalhistas, é auspiciosa na medida em que retira do trabalhador ignorante a totalidade das consequências do estabelecimento de relação de emprego à míngua da regra do concurso público. Isso em razão de a falta de conhecimento do trabalhador ou ignorância somada a deveres impostos ao empregador, Administração Pública, tais como, a culpa in contrahendo, o dever de informação e a proibição do venire contra factum proprium, exigir que os encargos decorrentes de escolhas incertas ou incorretas recaiam, em sua preponderância sobre o empregador não diligente.

Todavia, a maior repercussão da nulidade sobre a Administração Pública não elide sua percepção pelo empregado que, frente à afronta de pressuposto formal - o concurso público, terá, necessariamente, extinta sua vinculação laboral sem o recebimento de verbas rescisórias, porquanto o término da relação decorre de imposição constitucional, o art. $37, \S 2^{\circ}$, da CR.

Ainda, a escolha da boa-fé como critério definidor de direitos cumpre relevante papel de distinguir trabalhadores de má-fé, que são, ao lado de administradores públicos, coautores na violação de normas constitucionais, dos trabalhadores de boa-fé, ofertandolhes resultados distintos no que diz respeito à produção de efeitos jurídicos, retirando-se dos ímprobos os direitos trabalhistas e impondo-lhes o dever de reparar o erário.

Em complemento, serve a boa-fé para se afirmar que a cessação da prática de contratações sem a prévia aprovação por concurso público não será obtida com a punição do empregado incônscio, depende, sim, da responsabilização do administrador público por improbidade administrativa, nos termos da Lei 8.429/1992.

O adequado direcionamento dos esforços punitivos aos administradores acaba com qualquer vantagem que possa, eventual e perniciosamente, ser vislumbrada por eles no preenchimento subjetivo da estrutura pública de modo irregular, visto que a só restrição de direitos dos trabalhadores, posição adotada pelo TST, como se extrai da leitura da Súmula n. ${ }^{\circ} 363$, acaba por se revelar vantajosa ao empregador, com maior razão nos casos em que não é punido e pode, sem barreiras, lesar o erário e muitos outros trabalhadores em novas contratações irregulares. 
Sob o aspecto processual, a identificação da boa-fé como fato, especificamente a boa-fé subjetiva, que se manifesta no presente trabalho como a ignorância a respeito do vício da natureza jurídica do empregador, traz a necessidade de sua comprovação em juízo. Inexistindo presunção legal de boa-fé do trabalhador admitido pela Administração Pública sem prévia aprovação em concurso público, deve-se buscar a presunção comum, que resulta de operação lógica realizada pelo aplicador do direito que liga um fato conhecido a um fato desconhecido.

Mas, diante da dificuldade de demonstração desse estado de ignorância por meio de provas diretas, faz-se necessária a utilização de provas indiciárias, isto é, de fatos acessórios que permitam ao destinatário da prova formar sua convicção a respeito da boafé, presumindo-a diante dos fatos efetivamente demonstrados. Desse modo, não se pode esquecer de que os indícios são fatos acessórios, que podem ser comprovados por qualquer meio de prova, muito embora nem todos tenham a mesma eficácia.

Por conseguinte, a ausência de provas de indícios que amparam a presunção acarreta o julgamento em desfavor daquele que, sem êxito, sustenta estar de boa-fé, seja em razão do disposto no art. 818 da CLT e no art. 333 do CPC, seja em razão da excepcionalidade da produção de efeitos por negócios jurídicos nulos, notadamente nas hipóteses de violação de normas constitucionais de tutela do interesse público.

Logo, a demonstração em juízo da boa-fé do trabalhador, necessária à produção de efeitos específicos do contrato de emprego nulo, é exigência que se impõe por força de ausência de norma jurídica que a presuma, o que desafia a utilização de indícios que permitirão a formação de convicção judicial a seu respeito. Veja-se que o aspecto subjetivo da ignorância torna extremamente dificultosa a utilização de provas diretas, exigindo-se, assim, o recurso aos indícios, vale dizer, a fatos acessórios que, uma vez provados, levarão à formação da presunção comum ou judicial a respeito de algo.

Por fim, eventual ausência de prova boa-fé implicará julgamento desfavorável ao trabalhador, seja em razão da ausência de presunção legal de boa-fé na hipótese, seja em razão de a produção de efeitos em negócios jurídicos nulos constituir medida excepcional, tendo em vista a impossibilidade de alegar o desconhecimento da lei, o que, como visto, não se confunde com eventuais confusões acerca da natureza jurídica da empregadora. 


\section{BIBLIOGRAFIA.}

ALEXY, Robert. Teoria dos Direitos Fundamentais. Tradução de Virgílio Afonso da Silva da $5^{\text {a }}$ edição alemã. Malheiros, 2008.

ALMEIDA, Fábio Moreira de. O ingresso voluntário nas forças armadas e o concurso público. Revista da Escola da Magistratura Regional Federal da $2^{\mathrm{a}}$ Região. Rio de Janeiro. v.15. n.1. p.163-74. ago. 2011.

ALMEIDA, Fernando Henrique Mendes de. Contribuição ao estudo da função de fato. São Paulo: Saraiva, 1957.

AMARAL, Francisco. A boa-fé no processo romano. Revista de Direito Civil, Imobiliário, Agrário e Empresarial. Ano 20, outubro-dezembro, 1996.

ANDRADE, Everaldo Gaspar Lopes de. Princípios de direito do trabalho e seus fundamentos teórico-filosóficos: problematizando, refutando e deslocando o seu objeto. São Paulo: Ltr, 2008.

ANDRADE, Manuel A. Domingues. Teoria Geral da Relação Jurídica. Vol I: sujeito e objeto. Coimbra: Livraria Almedina, 2003.

ARAUJO, Luiz Alberto David; JÚNIOR, Vidal Serrano Nunes. Curso de direito constitucional. 7.ed. rev. e atual. São Paulo: Saraiva, 2003.

AZEVEDO, Antônio Junqueira de. Negócio jurídico: existência, validade e eficácia. 4. ed. atual. de acordo com o novo Código Civil (Lei n. 10.406, de 10-1-2002). São Paulo: Saraiva, 2002.

BARROS, Alice Monteiro de. Contrato de emprego do servidor público antinomias. in $\mathrm{O}$ Servidor público e a Justiça do Trabalho: homenagem ao Ministro Ronaldo José Lopes Leal. José Ronald Cavalcante Soares, coordenador. São Paulo: LTr, 2005.

BARROS, José Fernando Cedeno de. Disciplina das Relações Jurídicas Decorrentes de Medida Provisória não Convertida em Lei no Sistema Constitucional Brasileiro. REVISTA DE INFORMAÇÃO LEGISLATIVA. A. 29, n. 115, jul./set. 1992.

BASTOS, Celso Ribeiro. Curso de direito constitucional. 22. e.d. São Paulo: Saraiva, 2001.

BBC BRAZIL. Cientistas desenvolvem técnica para "ler" pensamentos. Disponível em: $<$ http://www1.folha.uol.com.br/bbc/1042322-cientistas-desenvolvem-tecnica-para-lerpensamentos.shtml>. Acesso em 29.05.2012.

BEDAQUE, José Roberto dos Santos. Poderes instrutórios do juiz. 5.ed. ver., atual. e ampl. São Paulo: Editora Revista dos Tribunais, 2011.

BELLO, Raquel Discacciati. O princípio da igualdade no concurso publico. Brasília: Revista de Informação Legislativa. v.33. n.131. p.313-20. jul./set. 1996. 
BESERRA, Fabiano Holz. Ação civil pública e relações de trabalho: tutela da moralidade e da probidade administrativa. Rio de Janeiro: Forense. São Paulo: Método, 2008.

BONAVIDES, Paulo e Paes de Andrade. História Constitucional do Brasil. 3.ed. Rio de Janeiro: Paz e Terra, 1991.

BRANDÃO, Claudio Mascarenhas. A exigência de concurso publico após a Constituição de 1988. São Paulo: LTr. revista legislação do trabalho. São Paulo. v.58. n.11. p.1320-3. nov. 1994.

BREDALGA, Roque. Fato consumado:pressupostos. Direito \& Justiça. REVISTA DA FACULDADE DE DIREITO DA PUCRS. Volume 19 - Ano XX - 1998.

CANOTILHO, José Joaquim Gomes. Direito Constitucional e Teoria da Constituição. $5^{\text {a }}$ ed. Almedina.

COVELLO, Sérgio Carlos. A presunção em matéria civil. São Paulo: Saraiva, 1983.

CARNELlUTI, Francesco. Sistema di diritto processuale civile. I - funzione e composizione del processo. Padova: Cedam, 1936.

CARVALHO, Diógenes Faria de; PEREIRA, Paulo Guimarães. A Boa-fé Objetiva como Parâmetro da Análise dos Contratos Administrativos. Fórum de Contratação e Gestão Pública. Ano 2. n. ${ }^{\circ} 23$ - Novembro de 2003. Editora Fórum.

CASSAR, Vólia Bomfim. Direito do trabalho. 4. ed. Niterói: Impetus, 2010.

CATHARINO, José Martins. Compêndio de Direito do Trabalho. vol. I, 3. ed. São Paulo: Saraiva, 1982.

CINTRA, Weiler Jorge; JÚNIOR, Weile Jorge Cintra. O "princípio" da ilegalidade eficaz. Revista Jurídica da Universidade de Franca. Ano 3, n. ${ }^{\circ}$ 4, maio. Franca, 2000.

COMPARATO, Fábio Konder. A afirmação histórica dos direitos humanos. 6.ed. ver. e atual. São Paulo: Saraiva, 2008.

CORDEIRO, António Manuel da Rocha e Menezes. Da boa fé no direito civil. Almedina, 2011.

COSTA, Judith Martins. A boa-fé no Direito Privado. São Paulo: Revista dos Tribunais, 1999.

A Proteção da Legítima Confiança nas Relações Obrigacionais entre a Administração e os Particulares. Revista da FACULDADE DE DIREITO da Universidade Federal do Rio Grande do Sul. Volume 22 - 2002.

Comentários ao novo Código Civil. V.5, tomo I: Do adimplemento e da extinção das obrigações. 4.e.d. Rio de Janeiro: Forense, 2003.

COSTA, Judith H. Martins. Princípio da boa-fé. in Revista da Associação dos Juízes do Rio Grande do Sul, n. ${ }^{\circ} 50$.

2002.

; BRANCO, Gerson Luiz Carlos. Diretrizes teóricas do novo código civil. Saraiva, 
COSTA, Wille Duarte. Conceito e estrutura da relação jurídica. Revista da Faculdade de Direito Milton Campos. 1 v. Belo Horizonte, 1994.

CRUZ, Alexandre Corrêa da. Os efeitos da contratação sem concurso pelo ente público: da impropriedade do enunciado 363 do TST. Disponível em: <http://www.femargs.com.br/revista03_cruz.html>. Acesso em 14.12.2012.

CUEVA, Mario De La. El nuevo derecho mexicano del trabajo: historia, princípios fundamentales, derecho individual y trabajos especiales. México: Editorial Porrua, 1977.

DELGADO, Mauricio Godinho. Curso de direito do trabalho. 10. ed. São Paulo: LTr, 2011.

Curso de direito do trabalho. 12. ed. São Paulo: LTr, 2013.

Princípios da dignidade humana, da proporcionalidade elou razoabilidade e da boa-fé no direito do trabalho: diálogo do ramo juslaborativo especializado com o universo jurídico geral. Revista de Direito do Trabalho. Ano 27, abril-junho de 2001. Editora Revista dos Tribunais.

DELlEPIANE, Antonio. Nova teoria da prova. Tradução da 5. ${ }^{a}$ edição Argentina por Érico Maciel 2. a edição. José Konfino - Editor. Rio de Janeiro, 1958.

DINAMARCO, Cândido Rangel. A instrumentalidade do processo. $14 .^{\mathrm{a}}$ ed. revista e atualizada. São Paulo: Malheiros, 2009.

DI PIETRO, Maria Sylvia Zanella. Concurso público na administração indireta. Revista de Direito Publico. Sao Paulo. v.23. n.93. p.129-32. jan./mar. 1990.

Direito Administrativo. 17.ed. São Paulo: Atlas, 2004.

FAVALE, Rocco. Nullità del contratto per difetto di forma. Rassegna di diritto civile. Saggi. 3/2003.

FERRARA, Francesco. A Simulação dos negócios jurídicos. Trad. Do Dr. A. Bossa. Saraiva \& Cia, 1939.

FERREIRA, Pinto. Comentários à Constituição brasileira. $6^{\circ}$ vol. São Paulo: Saraiva, 1994.

FERREIRA FILHO, Manoel Gonçalves. Direitos humanos fundamentais. 9. ed. rev. São Paulo: Saraiva, 2007.

FREITAS, Juarez. A anulação dos atos administrativos em face do princípio da boa-fé. Boletim de Direito Administrativo. Ano XI, n. ${ }^{\circ}$ 2, fevereiro, 1995.

GARCIA S., Alfonso. Los indicios. Estudios de Derecho. Medellin. v.49. n.113/114. p.203-15. mar./sept. 1989.

GENTILLE, Giuseppe. Il diritto del lavoro. Volume III: Il lavoro pubblico. 2.ed. Giuffrè Editore. 
GERCHMANN, Léo. Carta psicografada ajuda a inocentar ré por homicídio no $R S$. Disponível em: <http://www1.folha.uol.com.br/folha/cotidiano/ult95u122179.shtml>. Acesso em 29.05.2012.

GIORDANI, Francisco A. de Motta Peixoto. A contratação de servidor público sem concurso x princípio da dignidade da pessoa humana: colisão de direitos? Outro enfoque; conseqüências. Revista da AJURIS. Porto Alegre. v.29. n.87. p.67-76. set. 2002.

GOMES, Ana Cláudia Nascimento. Algumas Razões Doutrinárias para se Discordar da Recente (e da Também Antiga) Jurisprudência do Supremo Tribunal Federal Desfavorável à Competência da Justiça do Trabalho em Matéria de Trabalho Prestado a Ente de Direito Público. In: Revista do Ministério Público do Trabalho. Procuradoria-Geral do Trabalho - Ano XXI, março, 2011 - Brasília: Procuradoria Geral do Trabalho, LTr, 2011.

GOMES, Orlando. GOTTSCHALK, Élson. Curso de direito do trabalho. Rio de Janeiro: Forense, 2006.

HERNANDEZ, Fco. Javier Izquierdo e Monica Molina Garcia. La laboralización de los funcionarios públicos. Valencia: Tirant lo blanch, 1996.

IDIAKEZ, Francisco Javier Arrieta. El derecho del trabajo y las relaciones jurídicas calificadas como "zonas grises". Revista de la Universidad de Deusto. Vol. 57/2, Juliodiciembre. Bilbao, 2009.

LARENZ, Karl. Culpa in contrahendo, dever de segurança no tráfico e "contrato social". Revista de Direito Privado. Ano 9, n. ${ }^{\circ}$ 34, abr-jun./2008. Revista dos Tribunais. p. 343 a 352.

LEAL, Câmara. Cód. De Proc. Civ. e Com. Do Estado de São Paulo, 2. ${ }^{\circ}$ v.

LEITE, João Antonio G. Pereira. A presunção no direito do trabalho. Disponível em: <http://www.amatra4.org.br/cadernos/123-caderno-01?start=1>. Acesso em 30.06.2013.

LENT, Friedrich. Diritto Processsuale Civile Tedesco, parte prima: il procedimento di cognizione. Traduzione di Edoardo F. Ricci. Morano Editore, 1962.

LIMA, Carlos Eduardo de Azevedo. A Justiça do Trabalho e a Competência para o Processamento e Julgamento de Causas Envolvendo Trabalhadores Vinculados à Administração Pública: Algumas Reflexões. In: Revista do Ministério Público do Trabalho. Procuradoria-Geral do Trabalho - Ano XX, março, 2010 - Brasília: Procuradoria Geral do Trabalho, LTr, 2010.

LIMA, Francisco Gerson Marques de. Contratação de servidor público sem o certame exigido constitucionalmente - efeitos. IOB-Repertório de Jurisprudência: trabalhista e Previdenciário. São Paulo. n.21. p.365-360. nov. 1994.

LIMA, Thiago Emmanuel Chaves de. A violação do princípio do concurso público como ato de improbidade administrativa. Fórum Administrativo. Belo Horizonte. v.11. n.128. p.30-41. out. 2011.

LOMBARDO, Luigi. La prova giudiziale: contributo alla teoria del giudizio di fatto nel processo. Università di Catania. Publicazioni della Facoltà di Giurisprudenza. Giuffrè editore, 1999. 
LOPES, João Batista. Provas atípicas e efetividade do processo. Disponível em: $<$ http://www.arcos.org.br/periodicos/revista-eletronica-de-direito-processual/volumev/provas-atipicas-e-efetividade-do-processo>. Acesso em 29.05.2012.

LOUSSOUARN. M. Ivon. La buena fe. in Tratado de la Buena Fe en el Derecho. Marcos M. Córdoba (Diretor) - 1ª e.d. v.2. Buenos Aires: La Ley, 2004.

LORENZETTI, Ari Pedro. As nulidades o direito do trabalho. 2.ed. São Paulo: Ltr, 2010.

MAGALHÃES, Gustavo Alexandre; SOUTO MAIOR, Jorge Luiz. Efeitos da nulidade na contratação de servidores públicos. in O Servidor público e a Justiça do Trabalho: homenagem ao Ministro Ronaldo José Lopes Leal. José Ronald Cavalcante Soares, coordenador. São Paulo: LTr, 2005.

MALLET, Estêvão. Nulidade decorrente da contratação de emprego sem realização de concurso público. in O Servidor público e a Justiça do Trabalho: homenagem ao Ministro Ronaldo José Lopes Leal. José Ronald Cavalcante Soares, coordenador. São Paulo: LTr, 2005.

MALUF, Sahid. Curso de direito constitucional. 2. v. parte especial. 6.e.d. Sugestões Literárias S.A, 1972.

MARINONI, Luiz Guilherme; ARENHART, Sérgio Cruz. Prova. 2.ed. ver. e atual. São Paulo: Editora Revista dos Tribunais, 2011.

MARTINS, Flávio Alves. A boa-fé objetiva e sua formalização no direito das obrigações brasileiro. 2 e.d. Lumen Juris.

MARTINS, Gilberto Augusto Leitão. Admissão e dispensa de empregado publico - efeitos da contratação com inobservância ao princípio do concurso publico. LTr: legislação do trabalho. suplemento trabalhista. São Paulo. v.29. n.73. p.489-91. 1993.

MATTOS, Mauro Roberto Gomes de. Princípio do fato consumado no direito administrativo. Revista de Direito Administrativo. 220. I-IV; I-429, abr/jun. Rio de Janeiro, 2000.

MAZZILLI, Hugo Nigro. Concurso público na administração. Revista dos Tribunais. São Paulo. v.84. n.716. p.37-40. jun. 1995.

MELlo, Celso Antônio Bandeira de. Curso de Direito Administrativo. 22.ed. São Paulo: Malheiros, 2007.

"Regime único" dos servidores federais e o dever de concurso público. Revista da Procuradoria Geral do Estado de São Paulo. n.35. p.11-23. jun. 1991.

MELLO, Marcos Bernardes de. Teoria do fato jurídico: plano da existência. 16. e.d. São Paulo: Saraiva, 2010.

Teoria do fato jurídico: plano da validade. 9. e.d. São Paulo: Saraiva, 2009.

MENDES, Gilmar Ferreira. O princípio do concurso publico na jurisprudência do Supremo Tribunal Federal: alguns aspectos. Revista de Informação Legislativa. Brasília. v.25. n.100. p.163-74. out./dez. 1988. 
COELHO, Inocêncio Mártires; BRANCO, Paulo Gustavo Gonet. Curso de direito constitucional. São Paulo: Saraiva, 2007.

MILHOMENS, Jônatas. Da presunção de boa-fé no processo civil. $1^{\mathrm{a}}$ ed. Forense, 1961.

MORAES, Alexandre. Constituição do Brasil interpretada e legislação constitucional. 2. ed. São Paulo: Atlas, 2003.

MOTA, Maurício Jorge. A Teoria da Aparência. Disponível em: <http://www.estig.ipbeja.pt/ ac_direito/teoria_aparencia.pdf >. Acesso em 30.07.2012.

MUKAI, Toshio. Da segurança jurídica: direito adquirido nas relações contratuais. Revista de Direito Administrativo. Volume 99 - janeiro/março 1995. Editora Renovar.

2002.

A relação jurídico-adiministrativa. Revista Trimestral de Direito Público. n. ${ }^{0} 37$.

NAVES, Márcio Bilharinho. Circulação e forma jurídica. Revista da Procuradoria Geral do Estado de São Paulo. n. ${ }^{\circ}$ 44, dez. 95. São Paulo.

OLIVEIRA, Regis Fernandes. A proteção da boa-fé no Direito Administrativo. Revista dos Tribunais. ano 82 - fevereiro de 1993, vol. 688.

PASQUALOTTO, Adalberto. A boa-fé nas obrigações civis. In: MEDEIROS, Antonio Paulo Cachapuz (org.). O ensino jurídico no limiar do século. Porto Alegre: EDIPUCRS, 1997.

PEREIRA, Maria de Lurdes. Os estados subjetivos na representação voluntária. Revista da Faculdade de Direito da Universidade de Lisboa. Volume XXIX - n. ${ }^{\circ}$ 1. Coimbra Editora, 1998.

PEREIRA JUNIOR, Jesse Torres. Repercussões da emenda constitucional 19 sobre os concursos para provimento de cargos e empregos públicos. Revista de Direito Constitucional e Internacional. São Paulo. v.8. n.32. p.210-26. jul./set. 2000.

PERRINO, Angelina-Maria. Il rapporto di lavoro pubblico. Padova: CEDAM, 2004.

PIRAINO, Salvatore. Il contrato di pubblico impiego. Milano: Giuffrè Editore, 1975.

RÁO, Vicente. O Direito e a Vida dos Direitos: Noções Gerais. Direito Positivo. Direito Objetivo. Teoria Geral do Direito Subjetivo. Análise dos Elementos que Constituem os Direitos Subjetivos. $6^{\mathrm{a}}$.ed. Anotada e atualizada com o novo Código Civil por Ovídio Rocha Barros Sandoval. Editora Revista dos Tribunais, 2005.

RECRUTAMENTO e seleção de pessoal: validade dos procedimentos. BDA: Boletim de Direito Administrativo. São Paulo. v.10. n.9. p.542-6. set. 1994.

REIS, Carlos David Santos Aarão. O princípio da igualdade nos concursos públicos. Revista de Ciência Política. Rio de Janeiro. v.32. n.3. p.31-41. maio/jul. 1989.

RIVERO, Jean. HUGUES, Moutouh. Liberdades públicas. Tradução Maria Ermantina de Almeida Prado Galvão. São Paulo, Martins Fontes, 2006. 
ROCHA, João Luiz Coelho da. A administração estatal indireta e o concurso público. Revista de Direito Mercantil, Industrial, Econômico e Financeiro. São Paulo. v.31. n.87. p.17-20. jul./set. 1992.

RODRIGUEZ, Américo Plá. Princípios de direito do trabalho. Tradução de Wagner D. Giglio. São Paulo: Ltr. Ed. Da Universidade de São Paulo, 1978.

ROSENBERG, Leo. Tratado de derecho procesal civil. Tradução de Ângela Romera Vera. Tomo II. Libro segundo: el procedimento de sentencia. Buenos Aires: Ediciones Jurídicas Europa-America, 1955.

ROSENVALD, Nelson. Dignidade humana e boa-fé no código civil. São Paulo: Saraiva, 2005 .

RUBINSTEIN, Flávio. A bona fides como origem da boa-fé objetivo do Direito brasileiro. Revista da Faculdade de Direito USP. São Paulo. V. 99. 2004, pp. 574-658.

SANTOS, Moacyr Amaral. Prova Judiciária no Cível e Comercial. Volume I. Max Limonad.

SCHIAVI, Mauro. Manual de Direito Processual do Trabalho. 2. ed. São Paulo: LTr, 2009.

SILVA, José Afonso da. Curso de direito constitucional positivo. 13.ed. Malheiros Editores, 1997.

SILVA, Clóvis V. do Couto e. A obrigação como processo. Rio de Janeiro: Editora FGV, 2007.

SILVA, Héber Americano. Direito constitucional: o homem e a sociedade o Estado constitucional brasileiro. $1^{\circ}$ vol, 2. ed. Bauru: Jalovi, 1971.

SILVA, Homero Batista Mateus da. Curso de direito do trabalho aplicado, vol.1: Parte Geral. Rio de Janeiro: Elsevier, 2009

. Curso de direito do trabalho aplicado, vol. 6:contrato de trabalho. Rio de Janeiro: Elsevier, 2009.

SILVA, Otavio Pinto e. Subordinação, autonomia e parassubordinação nas relações de trabalho. LTr, 2004.

SILVEIRA, Alípio. A Bôa Fé no Direito Civil. Typ. Paulista, 1941.

SIMÃO, José Fernando. Direito Civil: contratos. 2 e.d. 2. reimp. São Paulo: Atlas, 2007.

SOUTO MAIOR, Jorge Luiz. Curso de direito do trabalho: teoria geral do direito do trabalho. vol I. Parte I. São Paulo: LTr, 2011.

STEINMETZ, Wilson. A Vinculação dos Particulares a Direitos Fundamentais. Malheiros, 2004.

SÜSSEKIND, Arnaldo. Institutições de direito do trabalho. Volume I. 22. ed. atual. Por Arnaldo Süssekind e João de Lima Teixeira Filho. São Paulo: LTr, 2005.

TEMER, Michel. Elementos de direito constitucional. 20. ed. Malheiros Editores. 
TEPEDINO, Gustavo; SCHREIBER, Anderson. Os efeitos da Constituição em Relação à Cláusula da Boa-fé no Código de Defesa do Consumidor e no Código Civil. Revista da EMERJ. Vol. 6. n. ${ }^{\circ}$ 23. 2003.

TURCO, Claudio. L'interesse negativo nella culpa in contrahendo. Rivista di Diritto Civile. Ano LIII, no 2 Marzo-Aprile. Padova: CEDAM, 2007.

VALLE, Vanice Lírio do. Emenda Constitucional n.51/06, processo seletivo público e novos regimes de vinculação de pessoal ao poder público: uma boa ideia para quem? A \& C: Revista de Direito Administrativo e Constitucional. Belo Horizonte. v.6. n.24. p.39-57. abr./jun. 2006.

VELASCO, Ignácio M. Podeva. A boa fé na formação dos contratos (direito romano). Revista de Direito Civil, Imobiliário, Agrário e Empresarial. Ano 16, julho-setembro/1992.

VILANOVA, Lourival. Relação Jurídica de Direito Público. Revista dos Tribunais. ano 94, volume 37, julho de 2005. Editora Revista dos Tribunais, 2005.

VILHENA, Paulo Emílio Ribeiro de. Relação de emprego: estrutura legal e supostos. 2. ed. ver., atual. e aum. São Paulo: LTr, 1999.

VIÑA, Jordi Carcía. Buena fe presente em todo el ordenamento jurídico. Julio-Agosto. Madrid: Nueva Imprenta, 2001.

ZANCANER, Weida. Da convalidação e da invalidação dos atos administrativos. 2.ed. $3^{\mathrm{a}}$ tiragem 03.2001. São Paulo: Malheiros, 2008. 